\title{
EVAPOTRANSPIRAÇÃO OBTIDA COM O SISTEMA RAZÃO DE BOWEN E UM LISÍMETRO DE PESAGEM EM AMBIENTE PROTEGIDO
}

\author{
THALES VINÍCIUS DE ARAÚJO VIANA
}

Engenheiro Agrônomo

Orientador: Prof. Dr. MARCOS VINICIUS FOLEGATTI

Tese apresentada à Escola Superior de Agricultura "Luiz de Queiroz", Universidade de São Paulo, para obtenção do título de Doutor em Agronomia, Área de Concentração: Irrigação e Drenagem

P I R A C I C A B A

Estado de São Paulo - Brasil

Dezembro - 2000 


\section{Dados Internacionais de Catalogaçāo na Publicaçāo (CIP) DIVISĀO DE BIBLIOTECA E DOCUMENTAÇĀO - Campus "Luiz de Queiroz"/USP}

Viana, Thales Vinicius de Araújo

Evapotranspiração obtida com o sistema razão de Bowen e um lisimetro de pesagem em ambiente protegido / Thales Vinícius de Araújo Viana. - - Piracicaba, 2000.

138 p. : il.

Tese (doutorado) - Escola Superior de Agricultura Luiz de Queiroz, 2000.

Bibliografia.

1. Cobertura plástica 2. Evapotranspiração 3. Lisimetro 4. Microclimatologia 5. Sistema automático de irrigação I. Título

CDD 631.7

Pormitida a copia total ou parcial deste documento desde que citada a fonte - 0 autor"

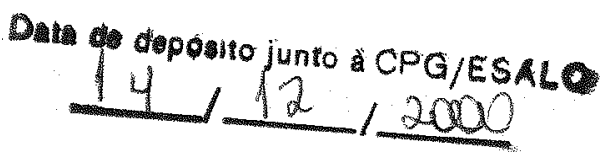


Aos meus pais,

VALDER (in memorian) e CELMA,

À minha esposa,

LUCIA,

e às minhas filhas,

STÉPHANNY e CAROLINE,

Dedicó. 


\section{AGRADECIMENTOS}

Ao Departamento de Engenharia Rural da Escola Superior de Agricultura "Luiz de Queiroz"/USP, pela oportunidade de realização do curso de doutorado.

À Universidade Federal do Ceará, pela permissão para realização do curso de doutorado, e em especial aos colegas do departamento de Engenharia Agrícola pela compreensão.

Ao prof. Marcos Vinícius FOLEGATTI, pelo apoio, convívio, amizade e orientações recebidas.

Ao prof. BENITO Moreira de Azevedo, pela longa amizade, cooperação e orientações recebidas.

Aos professores SENTELHAS, ANGELOCCI, NILSON, PEREIRA e FABIANO, pelos ensinamentos recebidos.

Aos demais professores dos departamentos de Engenharia Rural e Física e Meteorologia, pela cooperação na realização do curso e deste trabalho.

À Coordenação de Aperfeiçoamento de Pessoal de Nível Superior (CAPES), pela bolsa de estudo do Programa Institucional de Capacitação Docente e Técnica (PICDT).

À Fundação de Amparo à Pesquisa do Estado de São Paulo (FAPESP), pelos equipamentos que possibilitaram a realização deste trabalho.

Aos colegas de curso, pela amizade e convívio, e em especial ao VALDEMÍCIO, LEONARDO, LUISINHO, WELLINGTON, EDSON e ALEXANDRE, pela colaboração com este trabalho.

Aos funcionários do departamento de Engenharia Rural, pelo convívio e cooperação.

A todos os demais que contribuíram ou torceram para a execução deste trabalho. 


\section{SUMÁRIO}

Página

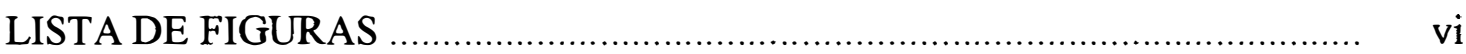

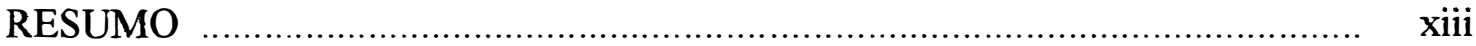

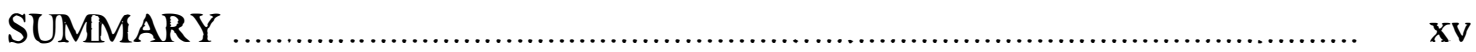

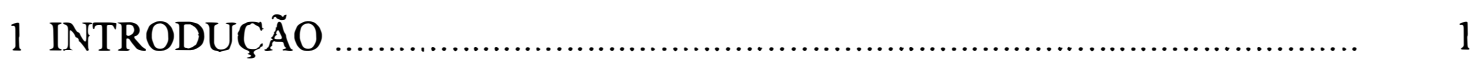

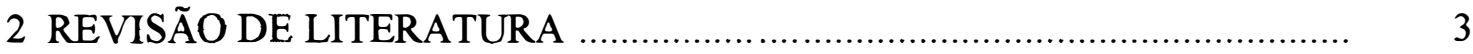

2.1 Efeitos da cobertura plástica sobre os elementos meteorológicos .................. 3

2.1.1 Radiação ........................................................................................... 3

2.1.2 Temperatura do ar .......................................................................... 5

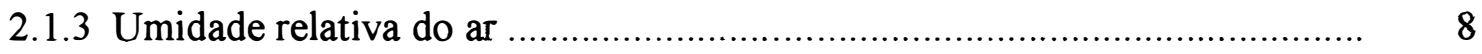

2.1.4 Evapotranspiração ............................................................................... 9

2.2 A evapotranspiração ........................................................................... 10

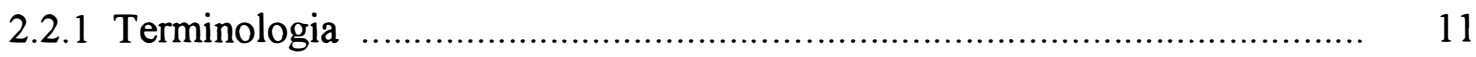

2.2.2 Medidas da evapotranspiração ......................................................... 12

2.2.3 Estimativas da evapotranspiração .............................................................. 14

2.3 O sistema automático da razão de Bowen ................................................... 18

3. MATERIAL E MÉTODOS …................................................................... 22



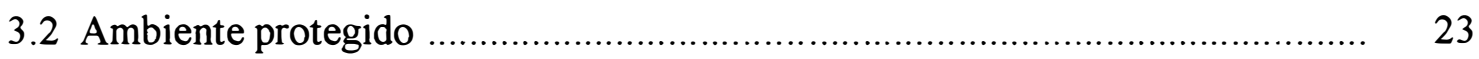

3.3 Cultura e condução do experimento ....................................................... 24

3.4 Evapotranspiração da cultura .................................................................. 26

3.4.1 Lisímetro de pesagem ..................................................................... 26

3.4.2 Método do Balanço de Energia ................................................................ 30 
Página

3.4.3 Sistema automático da razão de Bowen ............................................. 33

3.5 Evapotranspiração de referência ...................................................... 43

3.6 Elementos meteorológicos externos ....................................................... 45

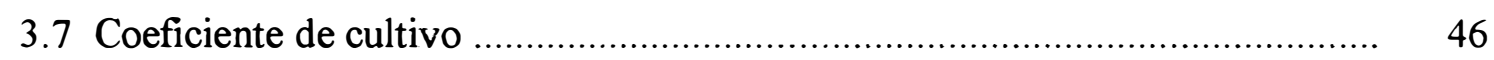

3.8 Perfil vertical de temperatura e umidade atmosférica .................................. 47

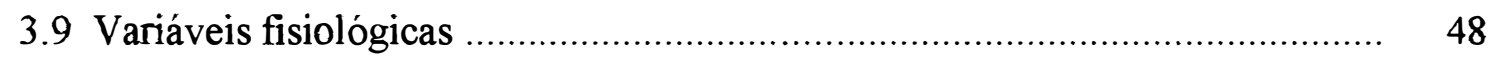

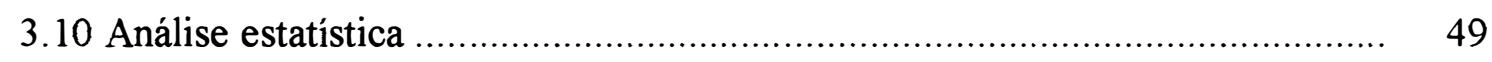

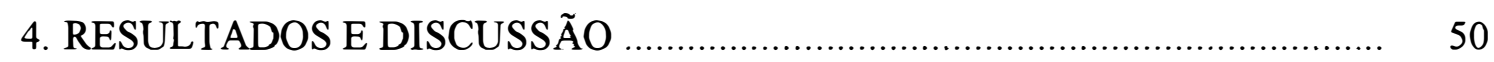

4.1 Efeitos da cobertura plástica sobre os elementos meteorológicos ................... 50

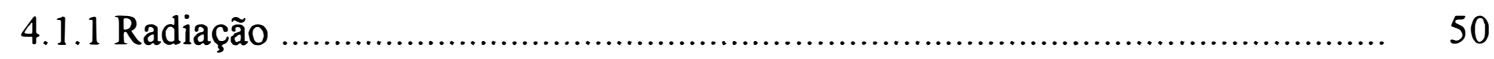

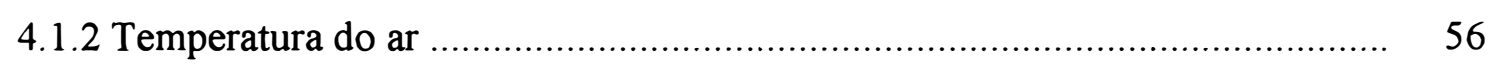

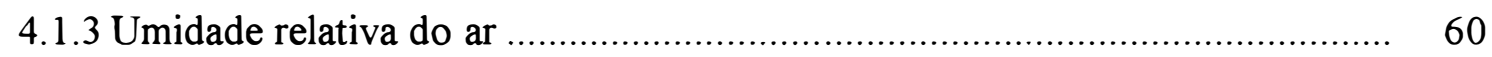

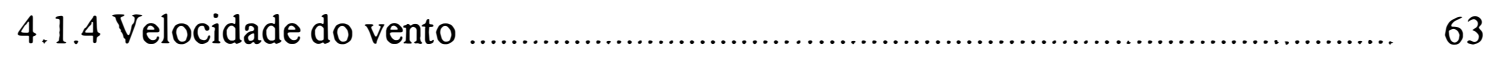

4.1.5 Evapotranspiração de referência .................................................. 65

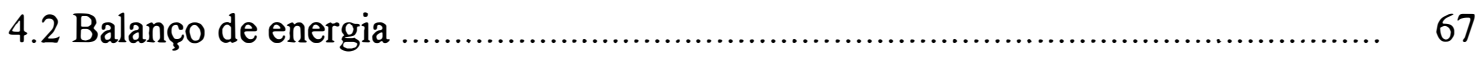

4.3 Evapotranspiração da cultura ...................................................... 71

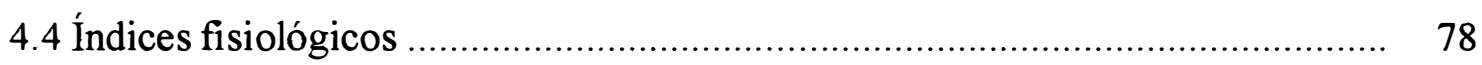

4.5 Coeficiente de cultivo .................................................................. 82

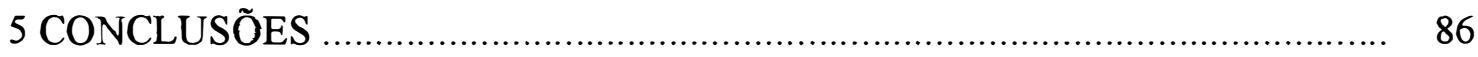



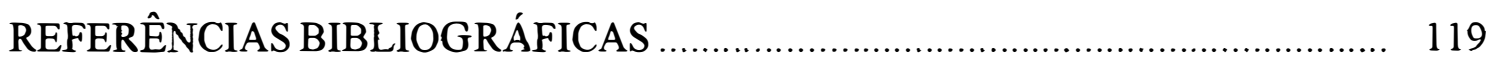




\section{LISTA DE FIGURAS}

Página

1 Ambiente protegido e disposição dos equipamentos

2 Ambiente protegido em perspectiva

3 Vista frontal do ambiente protegido

4 Plantio das mudas de alface em 4 fileiras por canteiro

5 Tensiômetro e tensímetro digital de punção

6 Vista lateral do lisímetro de pesagem instalado no interior do ambiente protegido

7 Planta da estrutura de sustentação do lisímetro

8 Preenchimento do lisímetro de pesagem com solo

9 Lisímetro de pesagem cultivado com a alface

10 Sistema automático da razão de Bowen instalado no centro do ambiente protegido

11 Ponto de sucção do ar com envoltório de proteção, instalado a 0,25 e 1,25 m sobre a alface, no interior do ambiente protegido 
Página

12 Higrômetro, tipo espelho, modelo Dew-10, utilizado na medida da temperatura do ponto de orvalho, no interior do ambiente protegido

13 Termopar, de cromel-constantan, utilizado na medida da temperatura do ar, a 0,25 e $1,25 \mathrm{~m}$ sobre a alface, no interior do ambiente protegido

14 Saldo radiômetro instalado sobre a alface, a 1,0 m de altura, no interior do ambiente protegido

15 Placa de fluxo de calor no solo e termopares de solo, instalados sob a alface, no interior do ambiente protegido

16 Sensor de temperatura e umidade relativa do ar instalado a 2,0 m de altura, no interior do ambiente protegido

17 Sensores de velocidade e direção do vento instalados a 2,0 m de altura, no interior do ambiente protegido

18 Sistemas automáticos de medição da razão de Bowen instalados na estação meteorológica

19 Painel de controle e sistema de aquisição de dados do SRB

20 Rádio receptor instalado a, aproximadamente, $1500 \mathrm{~m}$ da área experimental

21 Estação meteorológica automatizada

22 Visão parcial do perfil psicrométrico instalado no interior do ambiente protegido, sobre o canteiro central 
23 Variação ao longo do dia do saldo de radiação medido no interior do ambiente protegido, sobre a alface, e na estação meteorológica, sobre grama batatais, aos 16 DAT no primeiro cultivo (a) e aos 22 DAT no segundo cultivo (b), em Piracicaba, SP, no ano de 2000

24 Variação do total diário do saldo de radiação medido no interior do ambiente protegido, sobre a alface, e na estação meteorológica, sobre grama batatais, no primeiro (a) e no segundo (b) cultivos, em Piracicaba, SP, no ano de 2000

25 Correlação entre os saldos diários de radiação $(\mathrm{Rn})$ medidos no interior do ambiente protegido, sobre a alface, e na estação meteorológica, sobre a grama, no primeiro (a) e no segundo (b) cultivos, em Piracicaba, SP, no ano de 2000

26 Variação ao longo do dia do saldo de radiação $(\mathrm{Rn})$, medido no interior do ambiente protegido, sobre a alface, e radiação solar global $(\mathrm{Rg})$, medida na estação meteorológica, sobre grama, aos 16 DAT no primeiro cultivo (a) e aos 22 DAT no segundo cultivo (b), em Piracicaba, SP, no ano de 2000 ...

27 Correlação entre os totais diários do saldo de radiação, medidos no interior do ambiente protegido sobre a alface, e da radiação solar global, medidos na estação meteorológica sobre grama batatais, no primeiro (a) e segundo (b) cultivos, em Piracicaba, SP, no ano de 2000

28 Variação ao longo do dia da temperatura do ar medida, no interior do ambiente protegido e na estação meteorológica, aos 16 DAT no primeiro cultivo (a) e aos 22 DAT no segundo cultivo (b), em Piracicaba, SP, no ano de 2000 
Página

29 Variação ao longo do dia da diferença entre as temperaturas do ar registradas no interior do ambiente protegido e na estação meteorológica, aos 16 DAT no primeiro cultivo (a) e aos 22 DAT no segundo cultivo (b), em Piracicaba, SP, no ano de 2000

30 Correlação entre a temperatura média diária do ar obtida no interior do ambiente protegido e na estação meteorológica, no primeiro (a) e no segundo (b) cultivos da alface, em Piracicaba, SP, no ano de 2000

31 Perfil vertical de temperatura do ar no interior do ambiente protegido, aos 16 DAT no primeiro cultivo (a) e aos 13 DAT no segundo cultivo (b), em Piracicaba, SP, no ano de 2000

32 Variação ao longo do dia da umidade relativa do ar medida no interior do ambiente protegido e na estação meteorológica, aos $16 \mathrm{DAT}$ no primeiro cultivo (a) e aos 22 DAT no segundo cultivo (b), em Piracicaba, SP, no ano de 2000

33 Variação ao longo do dia da diferença entre a umidade relativa do ar registrada no interior do ambiente protegido e a registrada na estação meteorológica, aos 16 DAT no primeiro cultivo(a) e aos 22 DAT no segundo cultivo (b), em Piracicaba, SP, no ano de 2000

34 Correlação entre a umidade relativa média diária d o ar medida no interior do ambiente protegido e na estação meteorológica, no primeiro (a) e no segundo (b) cultivos da alface, em Piracicaba, SP, no ano de 2000 
35 Variação ao longo do dia da velocidade do vento medida no interior do ambiente protegido e na estação meteorológica, aos 67 (a) e 68 (b) dias Julianos, em Piracicaba, SP, no ano de 2000

36 Variação ao longo do dia da velocidade do vento medida, na estação meteorológica, e estimada, no ambiente protegido, aos $16 \mathrm{DAT}$ no primeiro cultivo (a) e aos 22 DAT no segundo cultivo (b), em Piracicaba, SP, no ano de 2000

37 Variação ao longo do dia da evapotranspiração de referência estimada, com a equação de Penman-Monteith, utilizando dados observados na estação meteorológica e no interior do ambiente protegido, aos 16 DAT no primeiro cultivo (a) e aos 22 DAT no segundo cultivo (b), em Piracicaba, SP, no ano de 2000

38 Correlação entre a evapotranspiração de referência estimada, com a equação de Penman-Monteith, utilizando dados observados no interior do ambiente protegido e na estação meteorológica, no primeiro (a) e no segundo (b) cultivos, em Piracicaba, SP, no ano de 2000

39 Variação no período diurno da razão de Bowen, no interior do ambiente protegido cultivado com alface, aos 16 DAT no primeiro cultivo (a) e aos 22 DAT no segundo cultivo (b), em Piracicaba, SP, no ano de 2000

40 Variação no período diurno dos fluxos de energia, no interior do ambiente protegido cultivado com alface, aos 16 DAT no primeiro cultivo (a) e aos 22 DAT no segundo cultivo (b), em Piracicaba, SP, no ano de 2000 
41 Variação da evapotranspiração da cultura medida no lisímetro de pesagem e estimada no sistema razão de Bowen (SRB), no primeiro (a) e segundo (b) cultivos da alface, em Piracicaba, SP, no ano de 2000

42 Correlação entre a evapotranspiração da cultura medida no lisímetro de pesagem e estimada no sistema razão de Bowen (SRB), no primeiro (a) e segundo (b) cultivos da alface, em Piracicaba, SP, no ano de 2000

43 Correlação entre a evapotranspiração da cultura medida no lisímetro de pesagem e estimada no sistema razão de Bowen (SRB), em dias com velocidade média diurna do vento superior a $1,5 \mathrm{~m} \cdot \mathrm{s}^{-1}$, no primeiro (a) e segundo (b) cultivos, em Piracicaba, SP, no ano de 2000

44 Correlação entre a evapotranspiração da cultura medida no lisímetro de pesagem e a estimada no sistema razão de Bowen, em dias com velocidade média diurna do vento inferior a $1,5 \mathrm{~m} \cdot \mathrm{s}^{-1}$, no primeiro (a) e no segundo (b) cultivos alface, em Piracicaba, SP, no ano de 2000

45 Variação no período diurno do gradiente de pressão de vapor aos 26 DAT no primeiro cultivo (a) e aos 23 DAT no segundo (b), em Piracicaba, SP, no ano de 2000

46 Variação no período diurno do gradiente de pressão de vapor aos 11 DAT no primeiro cultivo (a) e aos 12 DAT no segundo (b), em Piracicaba, SP, no ano de 2000

47 Índice de área foliar da alface, no primeiro (IAF1) e segundo (IAF2) cultivos, em Piracicaba, SP, no ano de 2000 
Página

48 Taxa de crescimento da cultura da alface, no primeiro (TCC1) e no segundo (TCC2) cultivos, em Piracicaba, SP, no ano de 2000

49 Taxa de crescimento relativo da alface, no primeiro (TCR1) e no segundo (TCR2) cultivos, em Piracicaba, SP, no ano de 2000

50 Taxa de assimilação líquida da alface, no primeiro (TAL1) e segundo (TAL2) cultivos, em Piracicaba, SP, no ano de 2000

51 Valores do coeficiente de cultivo da alface, estimado com dados meteorológicos externos $\left(\mathrm{Kc}_{(\mathrm{DE})}\right)$ e internos $\left(\mathrm{Kc}_{(\mathrm{DI})}\right)$, por quinquídio, no primeiro (a) e segundo (b) cultivos, em Piracicaba, SP, no ano de $2000 \quad \ldots$.

52 Valores do coeficiente de cultivo da alface, obtido com dados meteorológicos externos $\left(\mathrm{Kc}_{(\mathrm{DE})}\right)$ e internos $\left(\mathrm{Kc}_{(\mathrm{DI})}\right)$, por fase, no primeiro (a) e segundo (b) cultivos, em Piracicaba, SP, no ano de 2000 


\title{
EVAPOTRANSPIRAÇÃO OBTIDA COM O SISTEMA RAZÃO DE BOWEN E UM LISÍMETRO DE PESAGEM EM AMBIENTE PROTEGIDO
}

\author{
Autor: THALES VINÍCIUS DE ARAÚJO VIANA \\ Orientador: Prof. Dr. MARCOS VINÍCIUS FOLEGATTI
}

\section{RESUMO}

O objetivo deste trabalho foi o de avaliar as alterações microclimáticas em ambiente protegido, e estimar a evapotranspiração da cultura (ETc) com um sistema automático da razão de Bowen (SRB), comparando-a com a ETc medida com o uso de um lisímetro de pesagem. $\mathrm{O}$ experimento foi conduzido, em Piracicaba-SP, em ambiente protegido com cobertura plástica. A cultura utilizada foi a alface (Lactuca sativa, L.), variedade Verônica, em dois cultivos, um no outono e outro no inverno. A cultura foi irrigada através de mangueiras gotejadoras, e a quantidade de água a ser reposta ao solo foi estimada a partir do lisímetro de pesagem instalado no canteiro central. $O$ acompanhamento das condições hídricas do solo foi realizado através de tensiômetros. $\mathrm{O}$ SRB foi instalado no centro do ambiente protegido. Em uma estação meteorológica automatizada, próxima ao ambiente protegido, coletaram-se os dados climáticos externos.

$\mathrm{O}$ ambiente protegido afetou os elementos meteorológicos diminuindo o saldo de radiação, a velocidade do vento e a evapotranspiração de referência. O total 
evapotranspirado pela alface foi de 102,98 e $92,93 \mathrm{~mm}$, respectivamente, para o primeiro e o segundo cultivo. O SRB subestimou esses valores representando 75,9\% e $66,3 \%$ do total medido no lisímetro de pesagem, respectivamente, no primeiro e no segundo cultivo da alface.

O SRB não apresentou um bom desempenho na estimativa diária da evapotranspiração, em comparação com os valores medidos pelo lisímetro de pesagem. A redução da velocidade do vento e a contenção dos movimentos convectivos pela cobertura plástica diminuem a renovação das camadas de ar. Isso ocasiona baixos valores de gradiente de pressão parcial do vapor e dificulta a estimativa da evapotranspiração pelo SRB no interior do ambiente protegido. 


\title{
EVAPOTRANSPIRATION OBTAINED USING THE BOWEN RATIO SYSTEM AND A WEIGHING LYSIMETER IN A GREENHOUSE
}

\author{
Author: THALES VINÍCIUS DE ARAÚJO VIANA \\ Adviser: Prof. Dr. MARCOS VINÍCIUS FOLEGATTI
}

\section{SUMMARY}

The objectives of this work were to evaluate the microclimatics alterations and to estimate the crop evapotranspiration (ETc) in a greenhouse, using an automatic Bowen ratio system (BRS). The evapotranspiration estimated was compared with the evapotranspiration measured using a weighing lysimeter. The experiment was conducted in Piracicaba, São Paulo State, in a greenhouse. Lettuce (Lactuca sativa, L.), variety "Veronica", was used as crop and it was planted in fall and winter. The lettuce water requirements were measured by a weighing lysimeter and tensiometers were used as irrigation control. An automatic weather station was used to collected the weather data outside of the greenhouse.

The values of radiation balance, wind speed and the reference evapotranspiration were lower inside than outside of the greenhouse. The total evapotranspiration measured by the weighing lysimeter was $102.98 \mathrm{~mm}$ and $92.93 \mathrm{~mm}$, for the first and second crop cycle, respectively. The BRS underestimated the total lettuce evapotranspiration representing $75.9 \%$ and $66.3 \%$ of the measured evapotranspiration, for the first and second crop cycle, respectively. 
The daily data correlation for BRS did not show a good estimation for the reference evapotranspiration. The plastic cover decreased the wind speed and air movement. It caused low values of gradient of partial vapor pressure. That is the reason for the underestimation of evapotranspiration obtained by BRS in the greenhouse. 


\section{INTRODUÇÃO}

A utilização de coberturas plásticas, de menor custo e fácil manuseio, como os filmes de polietileno de baixa densidade (PEBD), possibilitaram um maior desenvolvimento do cultivo de diversas culturas em ambiente protegido. $\mathrm{O}$ ambiente protegido, com cobertura plástica, tem-se popularizado por permitir maior controle dos elementos microclimáticos ao longo do ano, e possibilitar a obtenção de produtos de melhor qualidade e maior regularização da oferta. Entretanto, diversas são as alterações nos elementos meteorológicos decorrentes da cobertura plástica, tais como redução na incidência de radiação solar e na velocidade do vento, com consequente redução da evapotranspiração.

A velocidade do vento tende a valores muito baixos, exceto quando o ambiente protegido dispõe de janelas e estas são mantidas abertas. Sem janelas abertas, a adveç̧ão é reduzida e há uma diminuição na renovação das camadas de ar. Um outro fator que altera as condições microclimáticas: é a contenção dos movimentos convectivos pela cobertura plástica.

A estimativa da evapotranspiração com o método da razão de Bowen, no Brasil, tem sido feita comumente através de observações com psicrômetros comuns. A popularização da microeletrônica permitiu a utilização de psicrômetros constituídos de pares termoelétricos de cobre-constantan conectados a um sistema de aquisição de dados (Cunha et al., 1996). A avaliação da estimativa da evapotranspiração pelo sistema automático da razão de Bowen (SRB) no Brasil é recente (Azevedo, 1999; Silva, 2000), tendo o SRB sido recomendado como substituto do lisímetro, na medida da evapotranspiração a céu aberto. 
O SRB registra instantaneamente, dentre outros, os gradientes de pressão parcial do vapor e de temperatura do ar, em duas alturas preestabelecidas, possibilitando a estimativa da evapotranspiração. Apresenta como maior vantagem, em relação aos lisímetros, a facilidade com que pode ser deslocado entre cultivos. Entretanto, no interior do ambiente protegido, os gradientes de pressão parcial do vapor e temperatura do ar são menores do que a céu aberto, devido à redução da velocidade do vento e a contração dos movimentos convectivos do ar pela cobertura plástica, o que pode dificultar a estimativa da evapotranspiração pelo SRB. Além disso, a ocorrência de gradiente de pressão parcial do vapor muito pequeno diminui a confiabilidade dos valores estimados pelo sistema razão de Bowen (Perez et al., 1999). Por conseguinte, a viabilidade ou não da utilização do sistema razão de Bowen no interior do ambiente protegido requer análise detalhada. Entretanto, não há informações disponíveis sobre o seu uso em ambiente protegido, fazendo-se necessária a avaliação do seu desempenho.

Este trabalho teve como objetivos avaliar os efeitos da cobertura plástica sobre os elementos meteorológicos e estimar, no interior do ambiente protegido, a evapotranspiração com o sistema automático da razão de Bowen, comparando-a com a medida com um lisímetro de pesagem. 


\section{REVISÃO DE LITERATURA}

\subsection{Efeito da cobertura plástica sobre os elementos meteorológicos}

A utilização de ambientes protegidos por coberturas plásticas implica diversas modificações micrometeorológicas que alteram a evapotranspiração. $O$ processo convectivo, originário do saldo de radiação positivo, é dificultado pela cobertura plástica que retém o ar quente, provocando a elevação da temperatura, alterando o balanço de energia e os diversos elementos micrometeorológicos, em relação ao ambiente externo (Seeman, 1979)

\subsubsection{Radiação}

A reflexão e a absorção promovidas pela cobertura plástica diminuem a incidência de radiação solar no interior do ambiente protegido (Seeman, 1979; Prados, 1986; Kurata, 1990, Farias et al., 1994; Sentelhas et al., 1997, Folegatti et al., 1997). Essa redução é variável em função do filme plástico (Al-Riahi et al., 1989; Mahrer, 1991; Sentelhas et al. 1999).

Sentelhas et al. (1997) observaram que a utilização, como cobertura, do polietileno de baixa densidade (PEBD), da manta, policloreto de vinila (PVC), tela branca (clarite, $50 \%$ ), tela preta (sombrite, $50 \%$ ) e tela verde $(50 \%)$ proporcionou uma atenuação da radiação solar global em 20,3\%; 37,4 \%; 35,0\%; 26,6\%; 41,2\% e 55,4 $\%$, respectivamente. Farias et al. (1993b) observaram uma redução média da radiação solar incidente provocada pelo PEBD de 17\%, e Mahrer (1991) encontrou uma redução variável entre $15 \%$ e $30 \%$. 
A quantidade de energia transmitida varia também com a orientação da cobertura e com o ângulo de incidência dos raios solares (Robledo de Pedro \& Vicente, 1988). Camacho et al. (1995) observaram que a transmissividade à radiação solar global do PEBD é maior na primavera do que no outono e, durante o dia, a maior transmissividade ocorre nas horas próximas ao meio-dia, ou seja, a transmissividade aumenta com a redução do ângulo de incidência dos raios solares. Scatolini (1996) comentou que a redução na transmissividade do PEBD no início da manhã foi devida à condensação do vapor d'água sobre a sua face interna, o que aumentou a absorção da radiação. Grafiadellis (1985) conclui que, ao longo do ano, a transmissividade média do polietileno de baixa densidade foi de $75 \%$. Resultados semelhantes foram obtidos por Martin \& Robledo (1981); entretanto, os autores ressaltam que o PEBD pode atingir picos de transmissividade de até $95 \%$. Assis \& Escobedo (1997), estudando a radiação solar global em ambientes protegidos com exposição leste-oeste (L-O) e norte-sul (N-S), observaram que na orientação L-O $75 \%$ da radiação global incidente foram transmitidos pela cobertura plástica de PEBD, ao passo que na orientação N-S ocorreu a transmissão de $65 \%$ da referida radiação. Resultados semelhantes foram obtidos por Galvani et al. (1998).

Um outro fator que também pode alterar a transmissividade do plástico à radiação é o seu tempo de uso. Reis \& Carrijo (1999) observaram que, após dois anos de uso, a transmissividade do PEBD foi reduzida, em média, em 5\%, devido à deposição de poeiras e formação de limo.

Sentelhas et al. (1999) observaram, ainda, diferenças na transmissividade do PEBD em função da sua coloração. Os autores observaram, em ambientes protegidos tipo túnel alto com orientação norte-sul, que a transmissividade do PEBD azul foi de $70,2 \%$, significativamente menor do que a registrada pelo transparente, $84,7 \%$.

Além de alterar a transmissividade da radiação solar direta, a cobertura plástica também influencia os valores de radiação difusa no interior do ambiente protegido. Para Prados (1986), a densidade de fluxo de radiação solar global no interior do ambiente protegido é menor do que a céu aberto, mas a fração difusa é maior. Comentários semelhantes fizeram Farias et al. (1993b) e Camacho et al. (1995). A 
fração da radiação difusa dentro do ambiente protegido, em condições de dia claro, pode atingir valores superiores a $60 \%$, ao passo que no ambiente externo essa fração atinge em média 20 \% (Martinez Garcia, 1978). Farias et al. (1993b) encontraram frações radiação difusa/global de $45 \%$ e $24 \%$ para dentro e fora do ambiente protegido, respectivamente.

Uma outra característica do plástico é possibilitar elevada transmissividade às radiações de ondas longa (Robledo de Pedro \& Vicente, 1988). A transmissividade do plástico às radiações de ondas longas pode atingir até $80 \%$ (Tapia, 1981), contribuindo consideravelmente para reduzir o saldo de radiação noturno no interior do ambiente protegido.

\subsubsection{Temperatura do ar}

Seeman (1979) comentou que a temperatura do ar no interior do ambiente protegido é variável, principalmente, com o seu tamanho e volume, com o tipo de polietileno, com a abertura ou não de janelas e cortinas, com o ângulo de incidência dos raios solares e com a cobertura do solo. Entretanto, as temperaturas mínimas e médias são pouco afetadas, ocorrendo o maior efeito sobre as temperaturas máximas.

Martinez Garcia (1986), estudando as alterações térmicas proporcionadas pelo ambiente protegido, concluiu que, apesar do avanço da técnica de plantio e da construção das coberturas plásticas, estas ainda são insatisfatórias do ponto de vista térmico, uma vez que durante o período diurno ocorrem temperaturas elevadas, que dificilmente são evitadas com a ventilação natural e, nas noites de inverno, com freqüência, ocorrem temperaturas inferiores às críticas das plantas cultivadas. Avaliando a temperatura no interior de ambiente protegido, com cobertura plástica e dotado de sistema de calefação por fluxo de ar quente, nos meses de inverno em Madri, Espanha, Martins \& Gonzalez (1995a) concluíram que a cobertura com PEBD não foi capaz, sem o uso do sistema de calefação, de superar as condições adversas de baixa temperatura no seu interior. 
As temperaturas mínimas no interior de ambientes protegidos com cobertura de PEBD são iguais ou ligeiramente superiores às externas (Montero et al., 1985; Farias et al., 1993a; Buriol et al., 1993a). Entretanto, há dias em que as temperaturas noturnas nesses ambientes são inferiores às registradas externamente (Herter \& Reisser Jr., 1987; Andriolo et al., 1989, Villele, 1989; Mills et al., 1990; Buriol et al., 1995). Fato também comentado por Buriol et al. (1993b), que observaram temperaturas inferiores no ambiente protegido, em noites com ventos fortes, pois estes, provavelmente, renovavam as camadas de ar junto à superfície do ambiente externo, evitando que a temperatura mínima do ar fosse mais baixa. Ainda, segundo esses autores, no interior do ambiente protegido, devido à reduzida renovação das camadas de ar, ocorreu um progressivo e ininterrupto resfriamento do ar, devido às perdas energéticas por radiação e por condução-convecção através do plástico. Para Tapia (1981) e Robledo de Pedro \& Vicente (1988), as baixas temperaturas noturnas no interior de ambientes protegidos ocorrem devido, principalmente, à elevada transparência do PEBD à radiação de onda longa.

Buriol et al. (1993a), ao analisarem as modificações micrometeorológicas causadas por coberturas plásticas de polietileno transparente e a sua influência sobre o crescimento da alface, concluíram que, nos meses mais frios, a cobertura proporcionou maior rendimento e precocidade na alface devido, principalmente, à maior temperatura do ar durante o período diurno. Entretanto, nos meses de primavera, houve vários dias com temperatura do ar elevada, e o crescimento foi prejudicado. Os autores relataram, entretanto, que a utilização da cobertura plástica aumentou a produtividade da cultura da alface, ao longo do ano.

Estudando o cultivo da uva em ambiente protegido com cobertura plástica, no verão, Schiedeck et al. (1997) afirmaram que a temperatura interna manteve-se, durante todo o período do experimento, superior às condições externas, mas após a retirada das janelas laterais a diferença das temperaturas mínimas dos ambientes interno e externo baixou, em média, de $4,2^{\circ} \mathrm{C}$ para $1,5^{\circ} \mathrm{C}$. Buriol et al. (1993b) também comentaram que a abertura ou o fechamento das cortinas laterais, à noite, afetou significativamente a temperatura mínima, sendo semelhante à externa quando as cortinas 
estavam abertas, e superior quando as cortinas foram fechadas. Mills et al. (1990) e Scatolini (1996), utilizando as cortinas abertas, relataram que as temperaturas mínimas no interior do ambiente protegido foram semelhantes às registradas a céu aberto.

Os maiores efeitos da cobertura plástica ocorrem sobre a temperatura máxima (Tanaka \& Genta, 1982; Villele, 1989; Farias et al., 1993a). As temperaturas máximas ocorridas no interior de ambiente protegido com cobertura plástica, em Pelotas, foram de $1,2{ }^{\circ} \mathrm{C}$ a $4,4^{\circ} \mathrm{C}$ superiores às ocorridas a céu aberto (Farias et al., 1993a). Martins \& Gonzalez (1995b), numa tentativa de reduzir as altas temperaturas sob ambiente protegido com cobertura plástica, avaliaram a possibilidade de resfriamento mediante sistema de ventilação e nebulização, em Madri, Espanha, e concluíram que: a) o sistema de ventilação não foi capaz de diminuir a temperatura no interior do ambiente protegido a valores inferiores a $30{ }^{\circ} \mathrm{C}$, necessitando, portanto, a implantação de um sistema adicional de resfriamento, para superar os momentos de alta temperatura da primavera; b) o sistema complementar de nebulização não foi suficiente para diminuir a temperatura interna do ambiente protegido a valores inferiores a $30^{\circ} \mathrm{C}$.

Furlan et al. (1999) observando o gradiente vertical de temperatura do ar no interior de ambiente protegido através de termopares de cobre-constantan, conectados a um sistema de aquisição de dados, instalados nas alturas de 0,5, 1,0, 2,0, 3,0 e 4,0 m, verificaram, no período noturno, uma pequena redução da temperatura do ar com a altura, e o inverso no período diurno, ou seja, ocorreu elevação da temperatura com a altura. Buriol et al. (1997) também observaram, no interior do ambiente protegido, aumento da temperatura do ar, com a altura, no período diurno.

Schneider et al. (1993) relataram que os valores de temperatura do solo foram mais elevados no interior do ambiente protegido por cobertura plástica, em comparação com as condições externas, tendo a diferença oscilado ao longo dia entre 1,7 e $6,3^{\circ} \mathrm{C}$. Comentaram, ainda, que no período diurno os processos convectivos foram interrompidos pela cobertura plástica, impedindo a saída do ar quente, que acumulado fez com que fosse registrada, no interior do ambiente protegido, temperatura máxima superior à ocorrida externamente. 


\subsubsection{Umidade relativa do ar}

Seeman (1979) comentou que os valores da umidade relativa do ar estão intimamente ligados à temperatura e são muito variáveis no interior do ambiente protegido por cobertura plástica. Montero et al. (1985) observaram que, normalmente, a umidade relativa no interior do ambiente protegido apresentou valores mais elevados que os obtidos externamente, no período noturno e inicio da manhã, e valores inferiores no período vespertino. Comentário idêntico fizeram Levit \& Gaspar (1988). Tanaka e Genta (1982) explicaram que a variação da umidade relativa, no período vespertino, ocorreu devido à maior elevação da temperatura do ar no interior do ambiente protegido. Em conseqüência, ocorreram valores de umidade relativa do ar internos inferiores aos obtidos externamente. Ainda, segundo os autores, à noite, em virtude da queda de temperatura, a umidade relativa aumenta bastante e torna-se superior à registrada externamente, devido à retenção do vapor d'água pela cobertura plástica. A umidade relativa do ar, no interior do ambiente protegido, normalmente, atinge $100 \%$ antes do nascer do sol, devido à queda acentuada de temperatura e à retenção de vapor d'água pela cobertura plástica (Prados, 1986). Entretanto, apesar de ocorrer elevada amplitude da umidade relativa, devido aos maiores valores noturnos e menores diários, os valores médios diários não diferiram dos valores externos (Martinez Garcia, 1978).

Um grande diferencial na variação da umidade relativa em ambientes protegidos com cobertura plástica é a abertura ou não de cortinas e janelas. A utilização de cortinas abertas possibilita que os ventos advectivos, que circulam no interior da cobertura plástica, transportem com mais facilidade o vapor d'água para o exterior, controlando a umidade e a temperatura no interior do ambiente protegido. Quando se utilizam as cortinas fechadas, os ventos de natureza convectiva transportam o vapor d'água para as camadas de ar mais elevadas do ambiente protegido, que sem mecanismos adequados de controle podem gerar taxas de umidade elevadas, provocando riscos fitopatológicos para as culturas estabelecidas em seu interior (Resi, 1997).

Schiedeck et al. (1997), estudando o cultivo da uva em ambiente protegido, com janelas fechadas, concluíram que a umidade relativa interna do ar foi sempre 
superior à externa, e esta superioridade pode ser explicada pela ventilação insuficiente. Entretanto, quando as janelas laterais foram retiradas, a ventilação interna passou a ocorrer de uma forma mais efetiva e, aliada às altas temperaturas, proporcionou ao ambiente interno, no período vespertino, valores de umidade relativa inferiores aos verificados a céu aberto.

Segundo Resi (1997), a umidade relativa do ar no interior do ambiente protegido, com janelas fechadas, foi maior em $2 \%$ do que a céu aberto, às $2: 00 \mathrm{~h}$, culminado em $10 \%$ às $8: 00 \mathrm{~h}$ da manhã, sendo que esta diferença foi diminuindo ao longo da tarde e atingiu o seu mínimo, 1\%, às 20:00 h. Farias et al. (1993a) observaram que, com cortinas abertas, a umidade relativa média diária dentro e fora do ambiente protegido foram semelhantes. Entretanto, relatam que a umidade relativa mínima foi sempre inferior dentro do ambiente protegido.

\subsubsection{Evapotranspiração}

A evapotranspiração no interior do ambiente protegido é menor que a registrada externamente devido à redução da incidência de radiação solar e da ação dos ventos, que são os principais fatores da demanda evapotranspirativa (Montero et al., 1985); entretanto, a temperatura elevada e a baixa umidade relativa, em alguns momentos, contribuem para o aumento da evapotranspiração no ambiente protegido. Ainda, segundo os autores, em geral, a evapotranspiração no interior do ambiente protegido fica em torno de $60 \%$ a $80 \%$ da verificada externamente. Resultados semelhantes obtiveram Montero et al. (1985), Prados (1986), Rosemberg et al. (1989), Martins (1992) e Martins \& Gonzalez (1995b). Já Farias et al. (1994) relataram que a evapotranspiração dentro do ambiente protegido variou de $45 \%$ a $77 \%$ da verificada na parte externa.

Boulard \& Jemaa (1993) também observaram que a evapotranspiração no interior do ambiente protegido foi inferior à registrada externamente, ressaltando ser o método de Penman-Monteith o mais adequado para a sua estimativa no referido ambiente. Faccioli (1998) também concluiu que o método de Penman-Monteith pode ser 
utilizado como padrão na estimativa da evapotranspiração de referência no interior de ambientes protegidos por cobertura plástica. Ainda, segundo o autor, que comparou os resultados obtidos com os medidos por um lisímetro de lençol freático de nível constante cultivado com grama no interior do ambiente protegido, a estimativa da evapotranspiração pelo método de Penman-Monteith não necessita de ajuste quando se utilizam os dados obtidos no interior do ambiente protegido.

Estudando modelos para estimativa da evapotranspiração no interior de ambientes protegidos, Scatolini (1996) chegou às seguintes conclusões: o ambiente protegido altera os elementos meteorológicos de maneira não uniforme, dificultando a estimativa da evapotranspiração a partir de elementos externos; as principais variáveis a serem consideradas na estimativa da evapotranspiração no interior do ambiente protegido são a radiação solar global e o índice de área foliar, sendo que os demais elementos meteorológicos, embora influenciem a evapotranspiração, não proporcionam grandes alterações na sua estimativa (inferiores a $1 \%$ ).

Prados (1986) recomendou, no interior do ambiente protegido, a utilização de coeficiente do tanque, Classe A, igual a 1,0. Já Vescambre \& Vaisse (1980) desaconselharam o uso do método tanque Classe A para estimar a evapotranspiração no interior do ambiente protegido.

\subsection{A evapotranspiração}

Em uma superficie vegetada ocorrem não somente $\mathrm{o}$ processo de evaporação, mas simultaneamente os processos de evaporação e de transpiração. A união desses processos foi denominada evapotranspiração, sendo esta uma função dos elementos meteorológicos, do solo e da planta.

Para Doorembos e Pruitt (1977), os elementos meteorológicos agem conjuntamente na formação do processo evapotranspirativo, sendo dificil distinguir o grau de importância de cada um. Ainda para os autores, quanto maior for a disponibilidade de energia solar, temperatura do ar e velocidade do vento, e menor umidade relativa do ar, maiores valores de evapotranspiração serão registrados. Para 
Chang (1971), em média para cultivos a céu aberto, a contribuição de radiação solar, velocidade do vento e umidade relativa do ar, em relação ao total evapotranspirado, foi de $80 \%, 14 \%$ e $6 \%$, respectivamente. Entretanto, outros fatores, tais como umidade do solo, tipo e porte da cultura, advecção de calor sensível de áreas circunvizinhas, etc., podem influir na evapotranspiração.

\subsubsection{Terminologia}

Thornthwaite (1948) definiu a evapotranspiração potencial (ETP) como a quantidade de água utilizada por uma extensa área vegetada, em crescimento ativo, sob condições ótimas de umidade do solo. A evapotranspiração de referência (ETo) foi definida, por Doorenbos \& Pruitt (1977), como a água utilizada por uma extensa superficie de grama, em crescimento ativo, com altura de 0,08 a $0,15 \mathrm{~m}$, cobrindo totalmente o solo e sem deficiência de água. Essa definição da ETo é semelhante a da ETP proposta por Thornthwaite, em 1948. Jensen (1973) propôs como cultura referencial a alfafa e definiu como evapotranspiração de referência a que se verifica em uma área sem deficiência hídrica, com bordadura mínima de $100 \mathrm{~m}$, sendo que a alfafa deve apresentar um porte de 0,30 a $0,50 \mathrm{~m}$ de altura. A evapotranspiração real ou atual (ETa) é aquela que ocorre em uma superfície vegetada, independentemente de sua área e das condições de umidade do solo (Thornthwaite, 1948; Pruitt et al., 1972; Villa Nova \& Reichardt, 1989; Pereira, 1997).

A evapotranspiração da cultura (ETc) é a quantidade de água utilizada por uma cultura agronômica, livre de doenças, desenvolvendo-se em uma área cultivada de um ou mais hectares, sob condições otimizadas de solo, incluindo água e fertilidade (Doorenbos \& Pruitt, 1977).

A advecção, segundo Millar (1964), é a troca, em virtude da heterogeneidade horizontal, de umidade e energia, proporcionando um aumento do consumo de calor latente em uma considerável faixa, após a interface seco/úmido, sendo este aumento reduzido à medida que o vento adentra a área úmida. Pelton et al. (1960) denominaram este aumento efeito varal. Para Pereira et al. (1997), nessas condições a 
evapotranspiração representa um valor exagerado pela advecção de calor sensível. Os autores denominaram a quantidade de água utilizada pelas plantas evapotranspiração de oásis (EO).

$\mathrm{Na}$ interface seco/úmido entre duas superficies distintas ocorrem mudanças abruptas nas condições do escoamento do ar, visto que cada superficie possui suas próprias características físicas e dinâmicas. Ocorre, nessas condições, a formação de uma camada limite superficial, sendo necessária a utilização de uma área tampão para uma adequada instalação do instrumental, minimizando-se as contribuições laterais. De maneira geral, quando o vento se desloca livremente de uma superficie mais rugosa para uma menos rugosa, esta área tampão equivale a uma bordadura de 40 vezes a altura da cultura (Pereira, 1998). Entretanto, a utilização de obstáculos afeta a velocidade do vento e a transferência de matéria e energia, reduzindo a demanda evapotranspirativa (Guyot, 1989). Essa redução na velocidade do vento e do efeito advectivo é variável com as características geométricas do obstáculo.

\subsubsection{Medidas da evapotranspiração}

A evapotranspiração pode ser medida através de equipamentos denominados lisímetros ou evapotranspirômetros. Os lisímetros são equipamentos constituídos de uma caixa impermeável, sendo preenchida com solo, mas mantida a sequência de horizontes do solo original. Os lisímetros, quando corretamente instalados, possibilitam medidas das mais precisas da evapotranspiração. Para Mantovani (1993), os lisímetros são parcelas experimentais onde é feito o balanço hídrico.

Aboukhaled et al. (1982) ressaltam que os lisímetros devem ser preenchidos corretamente, assemelhando-se o máximo possível às camadas externas de solo, e localizados de maneira a representar um ambiente específico. Quando adequadamente preenchidos, os lisímetros apresentam valores de evapotranspiração representativos da área circundante (Pruitt \& Angus, 1960; Howell et al., 1991). Na definição da localização do lisímetro, devem-se evitar obstáculos que possam alterar a radiação incidente e/ou o padrão de vento (Ritchie \& Burnet, 1968). 
Os lisímetros podem apresentar diversos formatos e tamanhos, e são classificados de acordo com o modo de medição do total evapotranspirado em: de pesagem, de drenagem, de lençol freático de nível constante e de flutuação. Para Howeel et al. (1991), a forma e área do lisímetro devem ser definidas a partir do tipo de cultura a ser utilizada, principalmente em função da dimensão do seu sistema radicular.

O lisímetro de pesagem é constituído de uma caixa impermeável, preenchida com solo, sob a qual é instalada uma célula de carga ou uma balança, para medir a sua variação de peso. $\mathrm{O}$ lisímetro de pesagem apresenta resultados satisfatórios em ambientes protegidos (Fernandes, 1996; Folegatti et al., 1997). Os lisímetros de drenagem são normalmente constituídos de grandes caixas com paredes impermeáveis enterradas até o nível do solo, plantados com vegetação idêntica à do terreno circundante, tendo no fundo da caixa um dreno, conectado a um vaso, no qual o excesso de água percolado é captado e medido (Camargo, 1971). O lisímetro de lençol freático constante consiste, além da caixa impermeável com solo e vegetação, de um sistema automático de reposição de água, possibilitando que o lençol freático, no interior da caixa, permaneça em nível constante, sendo a evapotranspiração proporcional à água que sai (Cruz, 1995). O lisímetro de flutuação consiste de um volume de solo contido num reservatório que flutua num fluido de alta densidade, por exemplo o $\mathrm{ZnCl}_{2}(\mathrm{McMilllan}$ \& Paul, 1961).

Silva et al. (1999b) avaliaram três tipos de lisímetros (de pesagem, de drenagem e com lençol freático de nível constante) na medição da evapotranspiração de referência (ETo). Segundo os autores, o lisímetro de pesagem mostrou-se eficiente na medida diária da evapotranspiração de referência, ao passo que os outros dois apresentaram um melhor funcionamento em períodos de 5 dias. Silva et al. (1999a), analisando o funcionamento de um lisímetro com sistema de pesagem, portando três células de carga, concluíram que este possui capacidade de medir a evapotranspiração a cada hora. Para Howeel et al. (1991), os lisímetros de pesagem são os mais utilizados em períodos menores que um dia. Entretanto, Ritchie \& Burnett (1968) afirmaram que intervalos de integração inferiores a 10-15 min são pouco recomendáveis. 


\subsubsection{Estimativas da evapotranspiração}

$\mathrm{Na}$ ausência de medidas diretas, como as obtidas através dos lisímetros, a evapotranspiração pode ser estimada por diversos métodos. Segundo Pereira et al. (1997), pode-se dividi-los de acordo com os princípios envolvidos em cinco categorias: empíricos, aerodinâmico, balanço de energia, combinados e correlações dos turbilhões.

Os métodos empíricos, tais como o do tanque Classe A, de Thornthwaite, de Camargo, de Makink, da Radiação Solar, de Hargreaves-Samani, etc., são, normalmente, resultantes de correlações entre a evapotranspiração medida em condições padronizadas e os elementos meteorológicos medidos em postos também padrões. $\mathrm{O}$ método aerodinâmico é um método micrometeorológico, com embasamento fisicoteórico da dinâmica dos fluídos e transporte turbulento. $\mathrm{O}$ método do balanço de energia representa a contabilidade das interações dos diversos tipos de energia com a superfície. Os métodos combinados retratam os efeitos do balanço de energia com aqueles do poder evaporante. O método de Penman foi o primeiro proposto dentro desta categoria, sendo posteriormente adaptado por Slatyer \& Mcilroy (1961), simplificado por Stanhill (1962) e modificado por Monteith (1965). O método dos turbilhões baseia-se nos deslocamentos verticais da atmosfera e conseqüente transporte das suas propriedades (Pereira et al. 1997).

Galvani et al. (1998), avaliando a evapotranspiração da alface, dentro e fora do ambiente protegido, concluíram que os valores de ETc estimados pelo tanque Classe A foram superiores aos dos métodos de Penman simplificado e Radiação. Os autores concluíram, ainda, que por diminuir a demanda hídrica o ambiente protegido contribui na redução nos custos de aplicação de água em plantios comerciais, otimizando os processos de irrigação.

Estudando a evapotranspiração e as respostas fisiológicas do feijão-vagem cultivado em substrato sob ambiente protegido, em condições ideais de umidade no solo, Martins \& Gonzalez (1995b) chegaram às seguintes conclusões: a) os valores de evapotranspiração real são bastantes próximos aos da evapotranspiração de referência interna do ambiente protegido estimados pelo método de Penman; b) a 
evapotranspiração de referência no interior do ambiente protegido é aproximadamente $60 \%$ da evapotranspiração de referência do ambiente externo; c) os valores de evapotranspiração real e evapotranspiração de referência interna representam, em média, a metade dos valores da radiação global incidentes no interior do ambiente protegido. Farias et al. (1994), estimando a evapotranspiração de referência pelo método de Penman, dentro e fora do ambiente protegido, concluíram que dentro esta foi sempre menor, sendo de $45 \%$ a $77 \%$ da verificada na parte externa.

O método do balanço de energia constitui-se, basicamente, na partição do saldo de radiação nos fluxos de calor latente de evapotranspiração, e nos fluxos de calor sensível no ar e no solo. Em certos momentos, os fluxos de calor sensível podem passar de consumidores para doadores de energia para o processo evapotranspirativo. A metodologia do balanço de energia, e conseqüentemente da razão de Bowen, já foi amplamente avaliada a céu aberto (Tanner, 1960; Vila Nova, 1973; Dunin et al., 1989; Kroon, 1989; Mastrorilli et al., 1989; Peterscmitt \& Katerji, 1989; Fontana et al., 1991; Maki, 1991; Moura \& Martins, 1992; Herbst et al., 1996; Bergamaschi et al., 1998; Steduto \& Hsiao, 1998), precisando ser, ainda, mais bem estudada em ambiente protegido.

A relação entre o fluxo de calor sensível do ar e o fluxo de calor latente de evapotranspiração constitui-se na razão de Bowen, conceito introduzido pelo próprio Bowen (1926). A referida razão apresenta valores bem distintos quando há diferenças significativas com relação à umidade do solo sendo que, normalmente, quanto mais úmido o solo mais próximos de zero tendem a ser os seus valores, pois maiores quantidades de energia são direcionadas ao processo de evapotranspiração. Quando há restrição hídrica uma maior parte da energia é utilizada no aquecimento do ar, o que resulta em um valor elevado da razão de Bowen. Reschke et al. (1997), em Ji-Paraná, RO, encontraram, em média, os seguintes valores para a estação chuvosa: 0,21 na área de floresta e 0,30 na área de pastagem. Para a estação seca os valores obtidos para a floresta e a pastagem foram de 0,26 e 0,31, respectivamente. Cargenel et al. (1996) obtiveram com feijão valores próximos a zero, um dia após a sua irrigação. Relataram, ainda, que à medida que a umidade do solo foi diminuindo os valores da razão de Bowen 
aproximaram-se de 0,45. Gutiérrez \& Meinzer (1994) encontraram, em cultivo de café, variações nos valores médios da razão de Bowen com a alteração dos valores do índice de área foliar. Segundo os autores, em condições ideais de umidade do solo, a razão de Bowen diminui de 0,92 para 0,36 quando o índice de área foliar aumentou de 1,4 para 6,7 .

Suzuki et al. (1999) analisaram a variação da razão de Bowen em um floresta de pinus coberta com neve tendo esta apresentado, predominantemente, valores superiores a 1,0. Os autores comentaram que os valores elevados da razão de Bowen foram decorrentes da baixa atividade fisiológica das plantas e, em conseqüência, maiores quantidades de energia foram direcionadas ao aquecimento do ar. Também observando a variação da razão de Bowen em pinus, porém no Canadá entre os dias Julianos 144 e 262, Joiner et al. (1999) obtiveram, como valores médios por experimento, 1,7 em 1994, e 1,5 em 1996, com médias máximas diárias de 4 e 6, respectivamente, nos dois ciclos experimentais. Ressaltaram que a ausência de irrigação complementar impediu o registro de valores da razão de Bowen mais próximos a zero.

Bergamaschi et al. (1988) observaram em cultivo de feijoeiro que maiores quantidades de radiação líquida foram utilizadas na evapotranspiração, quando a disponibilidade hídrica era maior. Além disso, segundo os autores, essa maior utilização da radiação líquida, na evapotranspiração, também tem relação direta com o aumento da demanda evaporativa da atmosfera e do índice de área foliar. Lira \& Oliveira (1997) analisaram as diferenças do balanço de energia sobre um canavial, na Zona da Mata alagoana, e concluíram haver diferenças significativas quando se comparam os valores de saldo de radiação e a sua partição nas estações do inverno e verão. Em julho, segundo os autores, o saldo de radiação médio foi de $8,78 \mathrm{MJ} \cdot \mathrm{m}^{-2} \cdot \mathrm{dia}^{-1}$, e $66 \%$ deste total foram utilizados pelo processo de evapotranspiração. Em dezembro o saldo médio foi de 15,88 MJ. $\mathrm{m}^{-2}$.dia ${ }^{-1}$, e apenas $46 \%$ foram utilizados para tal fim.

Cunha et al. (1996) estimaram a partição do saldo de energia em uma cultura de milho, a céu aberto, e chegaram às seguintes conclusões: a) a demanda da energia para o fluxo de calor latente de evaporação superou a demanda para o fluxo de calor sensível na atmosfera, aumentando a diferença entre ambos com $o$ 
desenvolvimento da cultura; b) o saldo de radiação foi utilizado, em proporções médias, para o ciclo de desenvolvimento, em $80 \%$ na forma de fluxo de calor latente de evaporação, $14 \%$ na forma de fluxo de calor sensível na atmosfera e $6 \%$ na forma de fluxo de calor no solo; c) a transferência de calor no solo acompanhou a disponibilidade energética na superfície, representada pelo saldo de radiação; d) a magnitude do fluxo de calor no solo e o índice de área foliar da cultura apresentaram uma relação inversa. Oliveira et al. (1997) analisaram os componentes do balanço de energia sobre um cultivo de amendoim irrigado a céu aberto, e concluíram que 93,2 \% da radiação disponível sobre a cultura foi utilizada para o fluxo de calor latente e $11,5 \%$ para aquecimento do solo. O fluxo de calor sensível no ar contribuiu, para o fluxo de calor latente, com 5,7\%, originário da advecção. Fontana et al. (1991) observaram em cultivo de soja que o fluxo de calor latente consumiu uma maior porção da radiação líquida, $95 \%$, quando cultivado em área irrigada, sendo este percentual reduzido para $78 \%$ na parcela não irrigada. Ressaltaram que parte da energia consumida pelo fluxo de calor latente foi originária da advecção de calor sensível. Bremer \& Ham (1999) concluíram que técnicas diferenciadas de cultivo de capim nativo afetaram os componentes do balanço de energia. Segundo os autores, em 44 dias observados, na área em que o capim foi inicialmente queimado, a radiação líquida apresentou um acréscimo médio diário de $8,6 \%$, possibilitando maiores valores médios diários do fluxo de calor latente de evapotranspiração, em relação à área que não foi queimada. Esse aumento ocorreu, segundo os autores, devido à redução do albedo na área queimada.

Grant (1975) estimou a evapotranspiração da cevada pelos métodos da razão de Bowen, balanço de energia e aerodinâmico, comparando-as com as medidas através de lisímetro de pesagem, tendo chegado à conclusão de que o melhor método de estimativa da evapotranspiração diária foi o da razão de Bowen. Já Green et al. (1984) comparando, na Nova Zelândia, a evapotranspiração de pastagem medida em lisímetro de pesagem e obtida através do método da razão de Bowen chegaram à conclusão de que os valores medidos e estimados apresentaram boa concordância no total diário evapotranspirado em dias sem chuvas. Quando dias chuvosos foram considerados, houve aumento na discrepância entre os dados. 
Apesar do seu largo emprego, alguns autores têm relatado problemas com o método do balanço de energia (Daamen et al., 1999; Ibanez et al., 1999). O método da razão de Bowen deve ter seu uso limitado ao período diurno (Heilman \& Brittin, 1989; Cellier \& Olioso, 1993; Kustas et al., 1996). Um ponto vulnerável do método é quando da aproximação da razão de Bowen do valor -1,0. Clothier et al. (1982) aconselharam, visando a uma maior eficiência do método, descartar os valores menores que $-0,5$, devido à sua inconsistência. Ortega-Farias et al. (1996) recomendaram descartar valores inferiores a -0,75. Para Perez et al. (1999), a faixa de descarte de dados deve ser variável com a acurácia do sensor, sendo tanto mais próxima de $-1,0$ quanto maior for a acurácia do instrumento de medida. Afirmaram, ainda, que devem ser descartados valores negativos da razão de Bowen, originários de ocorrência de condensação (fluxos positivos do calor latente de evapotranspiração), quando $\mathrm{Rn}-\mathrm{G}>0$. Unland et al. (1996) aconselharam o descarte de valores na faixa de $-0,7$ a $-1,3$, recomendação seguida nesta tese por ser a mais usual.

Para Howell (1991), o método da razão de Bowen produz bons resultados na estimativa da evapotranspiração em escalas de tempo de até um dia, mas não são recomendados para longos períodos. Para Blad \& Rosemberg (1974), em condições de advecção, o método do balanço de energia pode subestimar em até $20 \%$ as medidas lisimétricas. Ressaltaram, ainda, que comumente próximo ao nascer e pôr-do-sol ocorrem valores elevados da razão de Bowen devido à dificuldade de se obter gradientes de temperatura e pressão de vapor d'água. Para Angus \& Watts (1984), o método do balanço de energia somente proporciona bons resultados em solos úmidos. Esses autores relataram que em solos secos ou com consideráveis contribuições advectivas o modelo necessita de ajustes. Os autores propuseram, ainda, um modelo de ajuste dos dados para estas condições.

\subsection{O sistema automático da razão de Bowen}

Com o sistema automático da razão de Bowen (Bowen ratio system, BRS, Campbell Scientific, Logan, UT), é possível registrar instantaneamente a radiação 
líquida, o fluxo de calor no solo e gradientes de pressão parcial do vapor e temperatura do ar, em duas alturas, permitindo a estimativa do balanço de radiação e, conseqüentemente, da evapotranspiração. $O$ referido aparelho já foi testado em ambiente natural tendo estimado adequadamente a evapotranspiração (Tanner et al., 1987; Nie et al., 1992). Em muitos trabalhos, a evapotranspiração obtida através do sistema razão de Bowen foi utilizada como valor padrão para diversos fins (Malek, E., 1993; Allen et al., 1994; Bland et al. 1996; Malek et al. 1997; Rosset et al., 1997). Em outros, como referência para a avaliação de outros métodos de estimativa da evapotranspiração (Malek \& Binghan, 1993; Kjelgaard et al. 1994; Baselga \& Allen, 1996; Hatfield et al., 1996; Kjelgard, J.F., 1996; Jara et al., 1998; Tourula \& Heikinheimo, 1998).

Kjelgaard et al. (1994) compararam a evapotranspiração da cultura do milho, obtida com o sistema automático da razão de Bowen, com a estimada através da equação de Penman-Monteith e com uma equação modificada do balanço de energia, pela inclusão da temperatura do dossel no cálculo do fluxo de calor sensível. Os autores concluíram que, em média, os dois modelos superestimaram de $10 \%$ a $13 \%$ os valores obtidos no sistema razão de Bowen. Utilizando um sistema automático da razão de Bowen em área cultivada com milho, sob deficiência hídrica, Sauer et. al. (1998) concluíram que: nos dias nublados os valores médios diários da razão de Bowen foram próximos a 1,5 e, nos dias ensolarados, superiores a 2,3. Quando o solo foi umedecido os valores médios diários da razão de Bowen foram superiores a 0,87 nos dias nublados e a 1,5 nos dias ensolarados. Utilizando, também, sistemas automáticos da razão de Bowen, Malek \& Bighan (1997) analisaram a partição do saldo de radiação no deserto de Nevada, EUA. Concluíram que, em média, a referida partição ao longo do ano foi de $85,3 \%$ para o fluxo de calor sensível no ar, $14,6 \%$ para o fluxo de calor latente de evapotranspiração e $0,1 \%$ para o fluxo de calor sensível no solo.

Perez et al. (1999) estudaram o descarte de valores inconsistentes da razão de Bowen, com o SRB, visando ao aprimoramento do referido método. Os autores relataram que os dados inconsistentes apareceram, principalmente, no nascer e pôr-dosol, com Rn negativo, e à noite devido à inversão térmica. Uma outra fonte de ocorrência de erros foi o registro de $\lambda E>0$ (condensação), em períodos com $R n-G>0$. 
Afirmaram que isso ocorreu, normalmente, nos momentos com baixos fluxos de calor latente ( 0 a $50 \mathrm{~W} \cdot \mathrm{m}^{-2}$, geralmente no início da manhã ou no final da tarde) e, sob baixa advecção. Um outro problema citado pelos autores foram os baixos gradientes de pressão de vapor (menores que $0,03 \mathrm{kPa}^{-1}$ ) originários de advecção reduzida, chuvas ou irrigação. Nessas condições, ocorreram $\lambda E>0$ e valores da razão de Bowen próximos a $-1,0$. Os autores concluíram, ainda, que devem ser rejeitados os dados noturnos e obtidos após precipitação ou irrigação, e que a ocorrência de gradientes de vapor d'água muito pequenos afeta a consistência das estimativas do SRB.

No Brasil, a utilização do sistema automático da razão de Bowen é recente. O SRB foi inicialmente avaliado por Azevedo (1999), que comparou a evapotranspiração de referência estimada com a medida por um lisímetro de pesagem. $O$ autor conclui que o SRB estimou adequadamente a evapotranspiração de referência, tanto na escala diária como na horária, e recomendou-o para diversos estudos em substituição aos lisímetros devido à baixíssima mobilidade dos últimos em campo. Mais recentemente, Silva (2000) comparando a evapotranspiração da cultura do feijão medida em lisímetro de pesagem e estimada pelo sistema razão de Bowen também encontrou boa concordância entre os dados. Entretanto, ressaltou que apesar da boa concordância o sistema subestimou a evapotranspiração medida pelo lisímetro de pesagem.

Apesar de já avaliado em condições naturais não há registro da utilização do sistema razão de Bowen em ambiente protegido. Observou-se, ainda, que vários autores têm construído sistemas automatizados alternativos, de menor custo, para estimativa da razão de Bowen e obtido bons resultados a céu aberto (Ashktorab et al., 1989; Dugas et al., 1991; Cellier \& Olioso, 1993; Ashktorab et al., 1994; Frangi et al., 1996). Prueger et al. (1997) compararam os dados obtidos com um sistema simplificado de estimativa da razão de Bowen, no qual não havia alternância entre os fluxos de ar originários dos dois níveis, e sim dois psicrômetros, aos medidos por um lisímetro de pesagem. $\mathrm{O}$ autor concluiu que os dados medidos e estimados apresentaram boa concordância e, normalmente, diferiram em menos de $10 \%$.

Bausch \& Bernarnd (1992) realizaram estimativas do calor latente de evapotranspiração (LE), empregando um sistema automático da razão de Bowen com 
movimentação lateral dos braços, possibilitando realizar medidas psicrométricas com variações temporais e espaciais. Os resultados dos testes mostraram que o sistema Bowen-ratio construído estimava adequadamente a evapotranspiração, constituindo-se, também, em uma alternativa prática para substituir os lisímetros, e com a vantagem de maior mobilidade e apresentar menores custos. 


\section{MATERIAL E MÉTODOS}

\section{1 Área experimental}

O experimento foi conduzido em ambiente protegido, na área experimental de irrigação do Departamento de Engenharia Rural, da Escola Superior de Agricultura "Luiz de Queiroz", situada na fazenda Areão no município de Piracicaba, Estado de São Paulo, Figura 1.

O local está situado nas coordenadas geográficas $22^{\circ} 42^{\prime} 30^{\prime \prime} \mathrm{S}, 47^{0} 30^{\prime} 00^{\prime \prime}$ W e 576 metros. O clima é Cwa, ou seja, subtropical úmido conforme a classificação de Köepen, com verão chuvoso e seca no inverno, sendo de $1278,0 \mathrm{~mm}$ a precipitação média anual. As temperaturas médias mensais variam de $24,8{ }^{\circ} \mathrm{C}$ no verão a $17,1^{\circ} \mathrm{C}$ no inverno, com média anual de $21,4^{\circ} \mathrm{C}$ (Sentelhas et al., 1998).

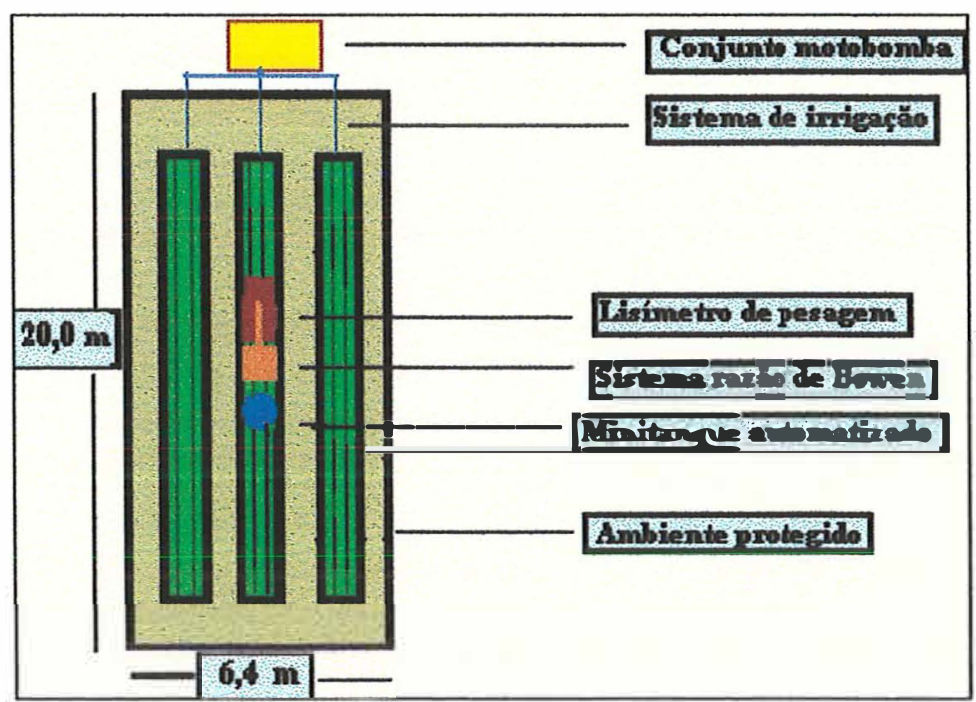

Figura 1 - Ambiente protegido e disposição dos equipamentos. 


\subsection{Ambiente protegido}

O ambiente protegido era do tipo estufa em forma de capela, com orientação no sentido leste-oeste, e tinha as seguintes dimensões: 6,4 m de largura, $20 \mathrm{~m}$ de comprimento, 4,2 $\mathrm{m}$ de altura na parte central e 3,0 m no pé-direito (Figuras 2 e 3). A estrutura era de ferro galvanizado com teto em forma de arco e cobertura de polietileno de baixa densidade (PEBD), transparente, com espessura de 0,1 $\mathrm{mm}$ e com aproximadamente 3 anos de uso. $\mathrm{O}$ ambiente protegido apresentava sistema de resfriamento através de abertura e fechamento de cortinas.

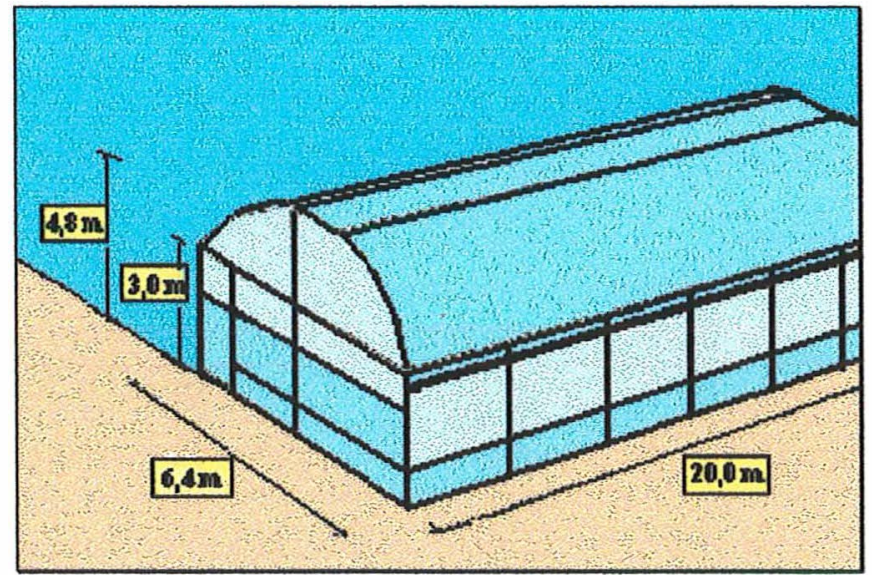

Figura 2 - Ambiente protegido em perspectiva.

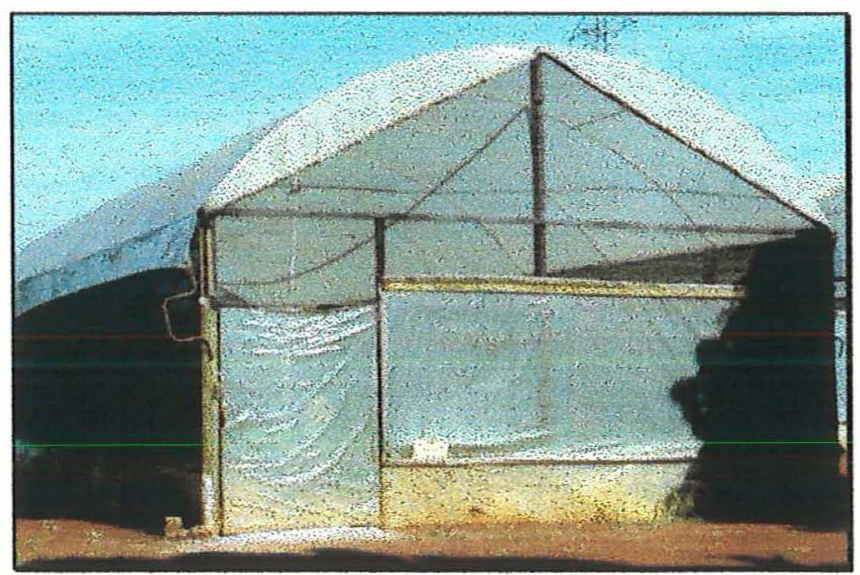

Figura 3 - Vista frontal do ambiente protegido. 


\subsection{Cultura e condução do experimento}

A cultura utilizada para a estimativa da evapotranspiração foi a alface (Lactuca sativa L.), cultivar Verônica, pertencente ao grupo manteiga com cabeça de porte grande, folhas rugosas, eretas e de coloração verde-clara. Cultivou-se a alface em dois períodos, sendo um no outono do ano de 2000, denominado primeiro cultivo, com transplantio em 7 de abril e início da colheita em 7 de maio, e outro no inverno do mesmo ano, com transplantio em 24 de junho e início da colheita em 5 de agosto, e denominado segundo cultivo. Em ambos, realizaram-se inicialmente a desinfeção do ambiente protegido, o preparo do solo com escarificação através de enxada rotativa, a adubação e a preparação dos canteiros. A adubação foi feita de acordo com a análise química do solo e a necessidade da cultura, e os canteiros foram confeccionados com $0,30 \mathrm{~m}$ de altura, 1,3 $\mathrm{m}$ de largura e 18,0 $\mathrm{m}$ de comprimento, e espaçados de 1,0 m.

A semeadura e conseqüente produção das mudas foram realizadas por uma empresa especializada, de reconhecida capacidade e idoneidade, em bandejas de isopor, adequadas à produção de mudas de hortaliças. Após seis dias da semeadura, realizou-se uma adubação foliar nitrogenada e o transplantio foi realizado aos 25 DAP (dias após o plantio), no primeiro cultivo, e aos 30 DAP, no segundo cultivo, quando as mudas estavam com quatro ou cinco folhas definitivas. As mudas de alface foram plantadas com espaçamento de $0,25 \times 0,25 \mathrm{~m}$, constituindo quatro linhas por canteiro (Figura 4). Escarificações complementares foram realizadas durante os dois períodos de cultivo com a finalidade de evitar o desenvolvimento de ervas daninhas e a formação de crostas superficiais. Nos dois períodos de cultivo foram feitas fertirrigações semanais, utilizando-se, em média, $50 \mathrm{~g}$ de uréia por canteiro, conforme recomendação originária da análise de solo. Foram também aplicados, de forma preventiva, pesticidas (inseticidas e fungicidas) para evitar que o desenvolvimento da cultura fosse prejudicado por pragas ou doenças, conforme recomendação de Ryder (1979) e Pereira e Leal (1989).

As cortinas foram mantidas abertas, nos dois cultivos, no período compreendido entre o transplantio e o início da colheita, visando a uma maior ventilação e, conseqüentemente, à redução dos riscos de pragas e doenças. 


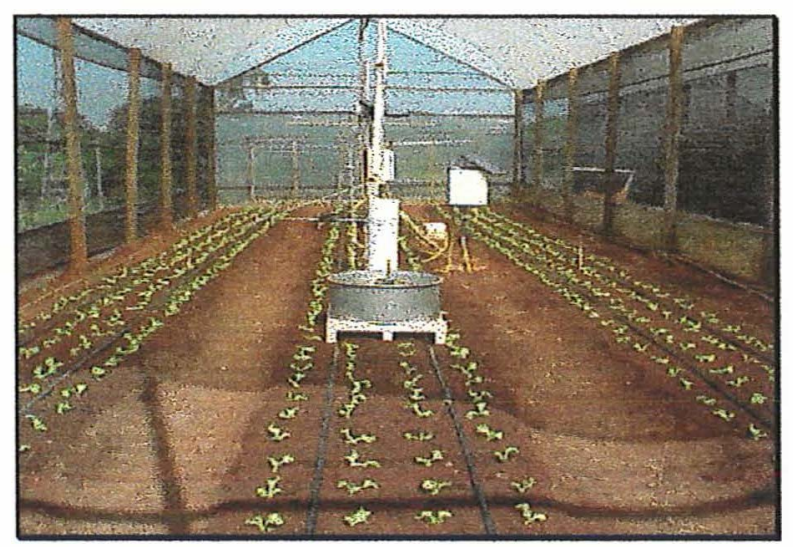

Figura 4 - Plantio das mudas de alface em 4 fileiras por canteiro.

O solo do local do experimento foi classificado como Terra Roxa Estruturada (Alfisol), série Luiz de Queiroz. Visando ao acompanhamento do potencial mátrico do solo instalou-se, na área experimental, a uma profundidade de $10 \mathrm{~cm}, 12$ tensiômetros, cujas leituras eram realizadas diariamente através de um tensímetro digital de punção, com medidas em bar (Figura 5). A tensão de água no solo utilizada para qualificar o momento de irrigar era de $0,01 \mathrm{MPa}(0,10 \mathrm{bar})$, conforme sugestão de Millar (1984) para obtenção de produção máxima com a cultura da alface. A cultura era irrigada através de mangueiras, com gotejadores espaçados de $20 \mathrm{~cm}$. Realizou-se, inicialmente, um teste de vazão com os gotejadores, tendo sido obtida uma vazão média, por gotejador, de 1,61. $\mathrm{h}^{-1}$, para a pressão de serviço na bomba de 0,06 MPa.

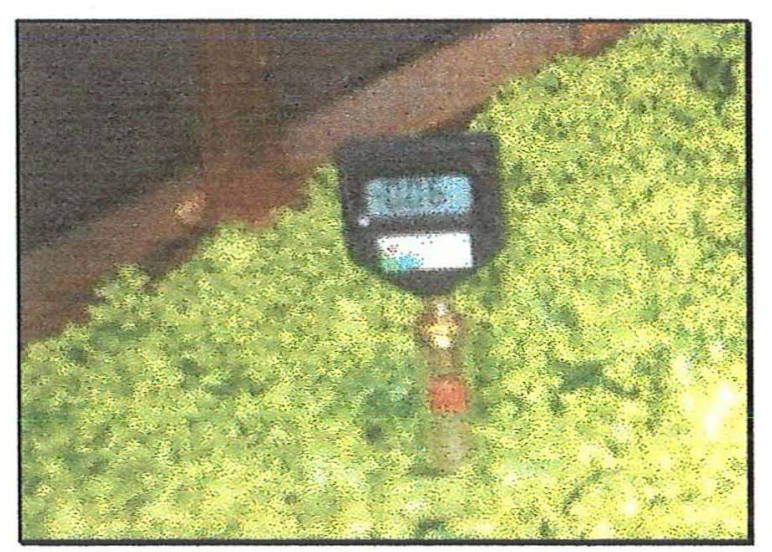

Figura 5 - Tensiômetro e tensímetro digital de punção. 


\subsection{Evapotranspiração da cultura}

A evapotranspiração da cultura no ambiente protegido foi medida por um lisímetro de pesagem, e estimada por um sistema automático da razão de Bowen.

\subsubsection{Lisímetro de pesagem}

O lisímetro de pesagem foi confeccionado a partir de caixas metálicas quadradas, de aço carbono, sendo que a interna tinha $0,45 \mathrm{~m}$ de profundidade e $1,0 \mathrm{~m}$ de largura e a externa profundidade de $0,75 \mathrm{~m}$ com largura de $1,08 \mathrm{~m}$ (Figura 6). A caixa externa foi fixada sobre camada de $0,05 \mathrm{~m}$ de brita $\mathrm{n}^{\circ} 2$ e apresentava um orificio de 0,03 $\mathrm{m}$ de diâmetro para, se necessário, drenar a água excedente.

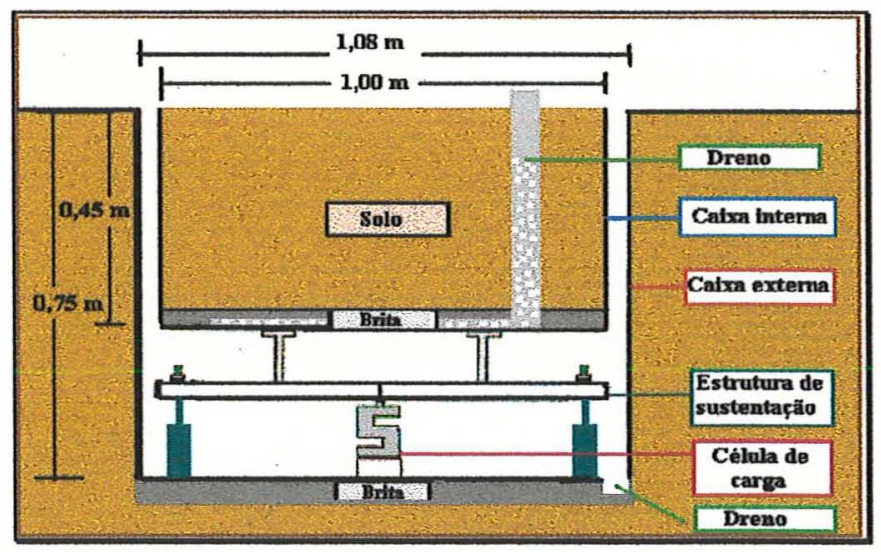

Figura 6 - Vista lateral do lisímetro de pesagem instalado no interior do ambiente protegido.

Sobre o fundo da caixa externa do lisímetro foi colocada uma base, de aço carbono, quadrada, com $0,05 \mathrm{~m}$ de espessura, apresentando lados com $0,10 \mathrm{~m}$ de largura e 1,0 m de comprimento, sobreposta em quatro parafusos, de aço inoxidável, com diâmetro de $0,05 \mathrm{~m}$ e altura de $0,20 \mathrm{~m}$, rosqueados a partir de $0,10 \mathrm{~m}$. Dois suportes em "V" fixados na base através de encaixes articuláveis convergem para o centro do fundo da caixa externa onde está fixada a célula de carga (Figura 7). Sobre cada suporte em 
"V" foram colocados dois parafusos rosqueados, de aço inoxidável e com diâmetro de $0,02 \mathrm{~m}$, para possibilitar a fixação da caixa interna. Os parafusos foram rosqueados para possibilitar ajustes que proporcionaram à caixa interna ficar em nível.



Figura 7 - Planta da estrutura de sustentação do lisímetro.

$\mathrm{Na}$ escavação para alocação do lisímetro, o solo de cada horizonte foi devidamente identificado e separado. No preenchimento foi utilizado o solo de cada camada do perfil, conforme seqüencia identificada, em uma tentativa de possibilitar a maior semelhança possível com o tipo e a profundidade dos diferentes horizontes do solo original, e conseqüentemente do solo da área circunvizinha ao lisímetro (Figura 8). No fundo da caixa interna foi colocada uma camada de $0,05 \mathrm{~m}$ de brita e uma tubulação de PVC com $0,0508 \mathrm{~m}$ de diâmetro, e perfurada em forma de U. Um tubo de PVC de 0,0508 $\mathrm{m}$ de diâmetro, com 0,60 $\mathrm{m}$ de altura e perfurado até a altura de 0,45 $\mathrm{m}$, foi conectado à tubulação descrita para possibilitar a sucção, através de conjunto motobomba, de possível excesso hídrico que viesse a se acumular na caixa interna. A camada de brita e a tubulação foram envolvidas com uma manta para drenagem ("biddin"), para evitar o acúmulo de solo na tubulação.

A célula de carga utilizada, modelo LCCA-2K, tinha capacidade para 910 $\mathrm{kg}$ e acurácia de $0,037 \%$ da sua capacidade e registrava o peso do lisímetro a cada segundo. O peso médio do lisímetro, a cada 20 minutos, era armazenado em um sistema de aquisição de dados, modelo $21 \mathrm{X}$. 


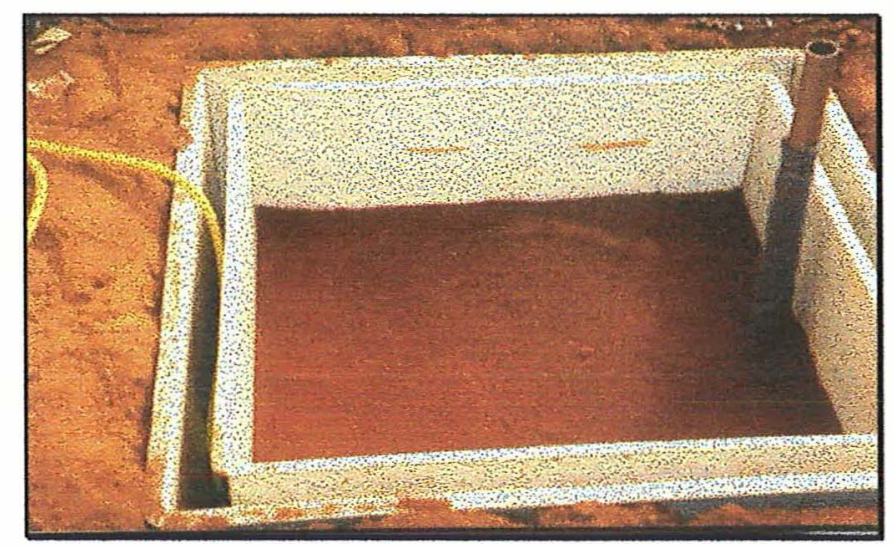

Figura 8 - Preenchimento do lisímetro de pesagem com solo.

Antes do primeiro cultivo, aproximadamente oito meses após o preenchimento do lisímetro, procedeu-se a sua calibração. Foram, inicialmente, adicionados, a cada 2 minutos, sucessivos pesos de 20,50, 100 e 500 gramas, até perfazer $10,0 \mathrm{~kg}$. Na calibração, a cada novo peso adicionado ao lisímetro, descartavamse os valores observados nos primeiros quarenta segundos, sendo a média dos valores dos 80 segundos restantes registrada pelo sistema de aquisição de dados. Em seguida, realizou-se o mesmo procedimento para a retirada dos pesos. No Anexo 1 pode-se observar o resultado da calibração do lisímetro, cujo coeficiente de determinação foi de 0,993 mostrando excelente precisão entre os dados obtidos. Através da calibração, concluiu-se que as variações de peso no lisímetro deveriam ser multiplicadas pela constante 1,4152 para registrar a variação de peso real.

O tempo de irrigação era assim calculado:

$$
\mathrm{T}=\frac{1,4152 * \Delta L_{c} * E_{L} * E_{G} * F_{C}}{E i * V_{G}}
$$

em que $\mathrm{T}$ é o tempo de irrigação, em horas; 1,4152 a constante de calibração do lisímetro; $\Delta \mathrm{L}_{\mathrm{C}}$ a diferença de leitura no lisímetro entre duas irrigações sucessivas, em $\mathrm{kg} ; \mathrm{E}_{\mathrm{L}} \mathrm{o}$ espaçamento entre linhas de irrigação, 0,50 m; $\mathrm{E}_{\mathrm{G}}$ o espaçamento entre gotejadores, 0,20 m; $\mathrm{F}_{\mathrm{C}}$ o fator de cobertura do solo; Ei a eficiência de irrigação, adotouse 0,90 e $V_{G}$ a vazão média do gotejador, $1,61 . \mathrm{h}^{-1}$. 
Visando a repor exatamente a mesma quantidade de água evapotranspirada no lisímetro de pesagem fecharam-se sobre ele os gotejadores, com o uso de cola de secagem rápida. A quantidade de água evapotranspirada entre duas irrigações, no lisímetro, era reposta através de um regador com acompanhamento em tempo real da leitura da célula de carga. Procurou-se, assim, manter, após as irrigações, aproximadamente, o mesmo peso do lisímetro. Tal procedimento, visou a evitar possíveis reposições hídricas, no lisímetro, diferentes do total evapotranspirado, em virtude de erros decorrentes das aproximações e/ou coeficientes utilizados no cálculo do tempo de irrigação ou de variações na vazão do gotejador, originárias de defeitos de fabricação, entupimentos, diferenças de pressão, etc.

A alface cultivada sobre o lisímetro de pesagem (Figura 9) foi submetida às mesmas técnicas de cultivo dos canteiros. A evapotranspiração diária era medida somando-se as alterações de peso ocorridas, no lisímetro, no período de luz solar. Estas alterações eram multiplicadas pelo fator 1,4152 . As irrigações eram realizadas à noite para evitar variações positivas, bruscas, de peso no lisímetro durante o período diurno, utilizado no cálculo da evapotranspiração. Nos Anexos 2 e 3 podem-se observar, respectivamente, a variação de peso do lisímetro em um dia em que não ocorreu irrigação (dia Juliano 177) e em outro que ocorreu (dia Juliano 178).

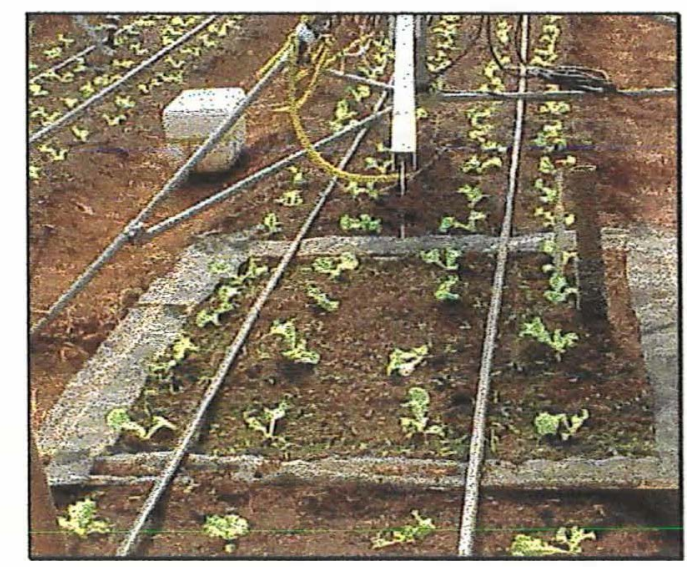

Figura 9 - Lisímetro de pesagem cultivado com a alface. 


\subsubsection{Método do Balanço de Energia}

Estimou-se a evapotranspiração, no interior do ambiente protegido, com o método do balanço de energia. Este método permite estimar as necessidades de água de comunidades vegetais, medindo-se a energia líquida disponível e separando-a em diferentes processos, destacando-se a evapotranspiração. Segundo Villa Nova (1973), Rosenberg (1983) e Pereira et al. (1997), a energia líquida disponível na superficie da terra se divide em fluxo de calor latente de evaporação (LE), fluxo de calor sensível para o ar $(\mathrm{H})$, fluxo de calor para o solo $(\mathrm{G})$, fotossíntese $(\mathrm{F})$ e trocas devidas à atividade metabólica e ao armazenamento nos tecidos das planta, podendo-se desprezar os dois últimos componentes, pois os seus valores são inferiores ao erro experimental na medida dos componentes principais. Portanto, a partição do saldo de energia considera, geralmente, apenas os três primeiros processos, sendo assim equacionado:

$$
\mathrm{R}_{\mathrm{n}} \cong \mathrm{LE}+\mathrm{G}+\mathrm{H}
$$

em que $R_{n}$ é o saldo de radiação; LE o fluxo de calor latente de evaporação; $G$ o fluxo de calor no solo e $\mathrm{H}$ o fluxo de calor sensível no ar.

Bowen (1926) relacionou os fluxos de calor sensível (H) e latente (LE), conforme equação a seguir, sendo esta conhecida como razão de Bowen $(\beta)$ e tendo sido amplamente utilizada na estimativa da evapotranspiração (Mastorilli et al., 1989; Fontana et al., 1991; Herbst et al., 1996; Steduto \& Hsiao, 1998).

$$
\beta=\frac{H}{L E}
$$

A partir da razão de Bowen e da eq. (02) pode-se isolar o fluxo de calor latente:

$$
\mathrm{LE}=\frac{R n-G}{(1+\beta)}
$$


sendo que à medida que $\beta$ se aproxima de -1 essa equação torna-se indefinida.

Pela dinâmica dos fluídos, a densidade de fluxo (F) de uma propriedade atmosférica qualquer $(\mathrm{X})$ por unidade de volume pode ser representada por uma equação de difusão:

$$
\mathrm{F}=-\mathrm{Kx} \cdot \frac{d X}{d z}
$$

em que $\mathrm{Kx}$ é o coeficiente de transporte turbulento da propriedade $\mathrm{X}$; $\mathrm{X}$ é a propriedade transportada; z é a altura acima da superficie.

Portanto, quando a propriedade transportada é o calor latente (LE), tem-se:

$$
\begin{aligned}
& \mathrm{LE}=-\mathrm{Ke} \cdot \frac{d(\lambda \cdot \rho \cdot q)}{d z} \\
& \mathrm{LE}=-\mathrm{Ke} \cdot \lambda \cdot \rho \cdot \frac{d q}{d z}
\end{aligned}
$$

sendo $\mathrm{Ke}$ o coeficiente de transporte turbulento do calor latente; $\lambda$ o calor latente de evaporação $\left(2,45 \mathrm{MJ} \mathrm{kg}^{-1}\right.$ a $\left.20^{\circ} \mathrm{C}\right)$ e $\rho$ a densidade do ar seco $\left(1,26 \mathrm{~kg} \cdot \mathrm{m}^{-3}\right)$. A umidade específica do ar (q) é dada por:

$$
\mathrm{q}=0,622 \cdot \frac{e a}{P}
$$

em que ea é a pressão parcial do vapor e $\mathrm{P}$ a pressão atmosférica local, utilizadas na mesma unidade. Por analogia com o fluxo de calor latente, o fluxo de calor sensível poderá ser estimado pela eq. (09):

$$
\mathrm{H}=-\mathrm{Kh} \cdot \rho \cdot \mathrm{cp} \cdot \frac{d T}{d z}
$$


em que Kh é o coeficiente de transporte turbulento do calor sensível, cp é o calor específico do ar (1,005 MJ.kg $\left.{ }^{-1} \cdot \mathrm{K}^{-1}\right)$ e T a temperatura do ar.

Como as propriedades são igualmente transportadas considera-se $\mathrm{Kh}=\mathrm{Ke}$. Logo,

$$
\beta=\frac{H}{L E}=\frac{c p \cdot d T}{\lambda \cdot d q}
$$

Substituindo a umidade específica, eq. (08), na eq. (10) tem-se:

$$
\beta=\frac{c p \cdot P \cdot d T}{0,622 \cdot \lambda \cdot d e a}
$$

sendo que, comumente, considera-se $\mathrm{dT}$ e dea como $\Delta \mathrm{T}$ e $\Delta \mathrm{ea}$, respectivamente. $\mathrm{O}$ coeficiente psicrométrico, $\gamma$, é dado por:

$$
\gamma=\frac{c p \cdot P}{0,622 \cdot \lambda}
$$

Então a razão de Bowen resulta em:

$$
\beta=\gamma \cdot \frac{d T}{d e a}
$$

Como a pressão parcial do vapor corresponde à pressão de saturação na temperatura do ponto de orvalho, o sistema automático da razão de Bowen mede a temperatura do ar e do ponto de orvalho e estima a pressão parcial do vapor, em duas alturas preestabelecidas, o que possibilita a utilização da eq. (13) para cálculo da razão de Bowen. 


\subsubsection{Sistema automático da razão de Bowen}

Instalou-se, visando a estimar a evapotranspiração da cultura, um sistema automático da razão de Bowen (Bowen ratio system, Campbell Scientific, Logan, UT) no centro do ambiente protegido (Figura 10). O aparelho consta, além da estrutura de sustentação, de dois braços metálicos, bomba e controlador de fluxo de ar, sensores micrometeorológicos e sistemas de aquisição e transmissão, via rádio, de dados.

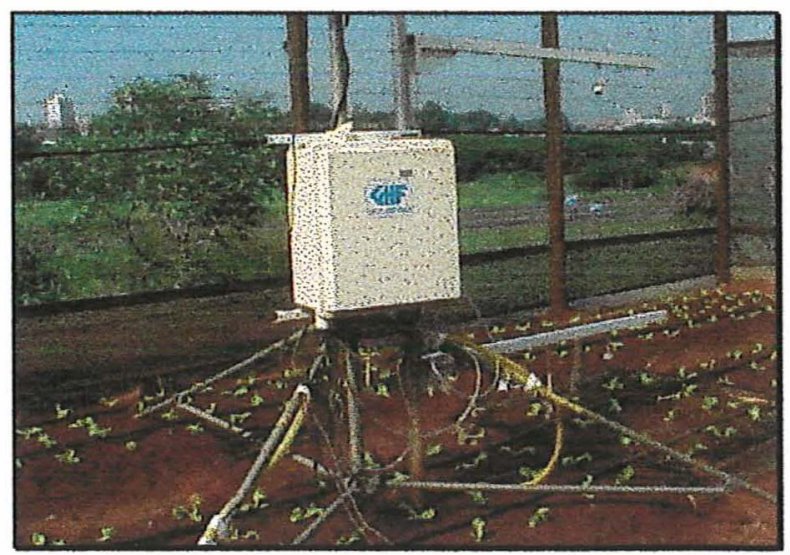

Figura 10 - Sistema automático da razão de Bowen instalado no centro do ambiente protegido.

Os dois braços metálicos (modelo BPA/UPR), do sistema automático de estimativa da razão de Bowen, SRB, foram instalados as alturas de 0,25 e 1,25 m acima da cultura estabelecida no lisímetro, sendo que estes foram deslocados verticalmente à medida que a alface se desenvolveu, de modo a manter as distâncias prefixadas. Sob cada braço havia uma mangueira que canalizava o ar succionado na sua extremidade para o interior do aparelho. O ponto de sucção do ar, na extremidade da mangueira, constituía-se de um sistema filtros de ar de teflon, com poros de 1,0 $\mu \mathrm{m}$, e de envoltório para proteção a danos ambientais (Figura 11). A finalidade do sistema de filtros era impedir a penetração de poeira e líquidos no sistema. Os braços do SRB, e, conseqüentemente, os sensores de temperatura e de sucção do ar, foram colocados sobre 
o lisímetro para minimizar o efeito de possíveis variações horizontais, de temperatura e/ou de pressão parcial do vapor, no interior do ambiente protegido.

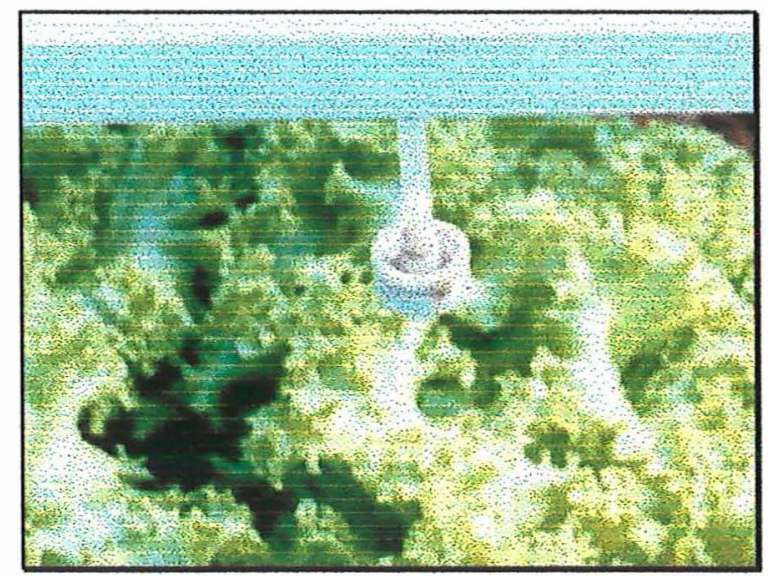

Figura 11 - Ponto de sucção do ar com envoltório de proteção, instalado a 0,25 e $1,25 \mathrm{~m}$ sobre a alface, no interior do ambiente protegido.

O SRB succionava o ar ambiente, pelas mangueiras, utilizando uma pequena bomba. $\mathrm{O}$ ar succionado era direcionado para um controlador de fluxo de ar, modelo $023 \mathrm{~A}$, no qual havia um higrômetro, tipo espelho, modelo Dew-10 (Figura 12), através do qual era estimada a temperatura do ponto de orvalho, conforme metodologia proposta por Lemon (1960). A cada 2 minutos eram alterados os fluxos de ar por uma válvula, ou seja, nos dois primeiros minutos eram succionadas amostras de ar do braço inferior e, nos dois seguintes, do braço superior, e assim sucessivamente. Em cada ciclo, os primeiros quarenta segundos de cada observação eram dedicados à estabilização do sistema, sendo os 80 segundos restantes utilizados na estimativa da nova temperatura do ponto de orvalho. Como a leitura ocorria a cada segundo e a temperatura do ponto de orvalho era medida durante 1 minuto e 20 segundos, por ciclo de 4 minutos, foram geradas 400 medições/20 minutos/nível. O valor médio dessas medições era armazenado em um sistema de aquisição de dados, modelo $21 \mathrm{X}$. O aparelho utiliza um único psicrômetro, para as duas alturas observadas, visando a reduzir a ocorrência de erros sistemáticos, conforme proposição de Fuchs \& Tanner (1970). 


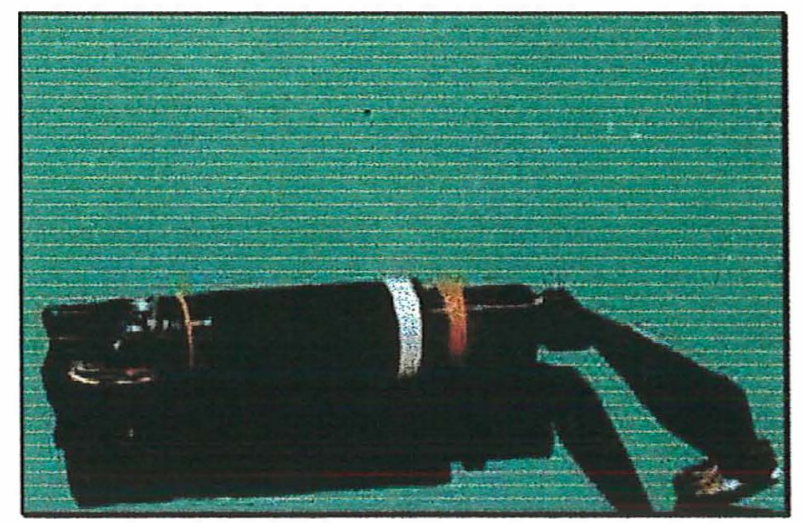

Figura 12 - Higrômetro, tipo espelho, modelo Dew-10, utilizado na medida da temperatura do ponto de orvalho, no interior do ambiente protegido.

A medição da temperatura do ponto de orvalho, nos dois níveis, apresentava uma resolução de $\pm 0,003{ }^{\circ} \mathrm{C}$ e precisão de $\pm 0,05{ }^{\circ} \mathrm{C}$. A partir da temperatura do ponto de orvalho, o sistema estimava com precisão de $0,01 \mathrm{kPa}, \mathrm{a}$ pressão parcial do vapor nos dois níveis citados, através da equação descrita por Lowe (1976):

$$
e s=a_{0}+a_{1} \cdot T+a_{2} \cdot T^{2}+a_{3} \cdot T^{3}+a_{4} \cdot T^{4}+a_{5} \cdot T^{5}+a_{6} \cdot T^{6}
$$

em que es é a pressão parcial do vapor $(\mathrm{mb}), \mathrm{t}$ é a temperatura do $\operatorname{ar}\left({ }^{\circ} \mathrm{C}\right), \mathrm{e} \mathrm{a}_{0}, \mathrm{a}_{1}, \mathrm{a}_{2}$, $a_{3}, a_{4}, a_{5} e a_{6}$, constantes adimensionais, cujos respectivos valores são: 6,10779, $4,43651 \cdot 10^{-1}, 1,42894 \cdot 10^{-2}, 2,65064 \cdot 10^{-4}, 3,03124 \cdot 10^{-6}, 2,03408 \cdot 10^{-8} \mathrm{e}$ $6,13682 \cdot 10^{-11}$. Para converter o valor da pressão parcial do vapor de mb para $\mathrm{kPa}$, multiplica-se por 0,1 .

A temperatura do ar era medida nos dois níveis com termopares de cromelconstantan, modelo TCBR-3 (Figura 13), colocados no extremo de cada braço do SRB. A resolução dos termopares era de $0,006{ }^{\circ} \mathrm{C}$ e os dados médios para cada 20 minutos (média de 1200 observações/nível) foram armazenados no sistema de aquisição de dados. 


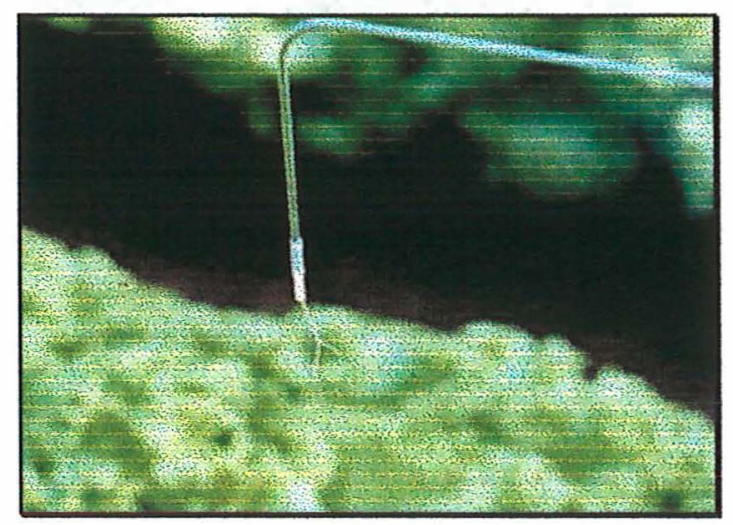

Figura 13 - Termopar, de cromel-constantan, utilizado na medida da temperatura do ar, a 0,25 e 1,25 m sobre a alface, no interior do ambiente protegido.

Acrescentou-se ainda ao SRB, para estimativa do balanço de energia, vários outros sensores micrometeorológicos. A radiação líquida foi medida, a cada segundo, a partir de um saldo radiômetro (modelo Q7.1 Net Radiometer-REBS; espectro de 0,25 a $60 \mu \mathrm{m}$ ) instalado a 1,0 m de altura (Figura 14). Os valores médios para cada 20 minutos, de radiação líquida, também foram armazenados no sistema de aquisição de dados, modelo $21 \mathrm{X}$.

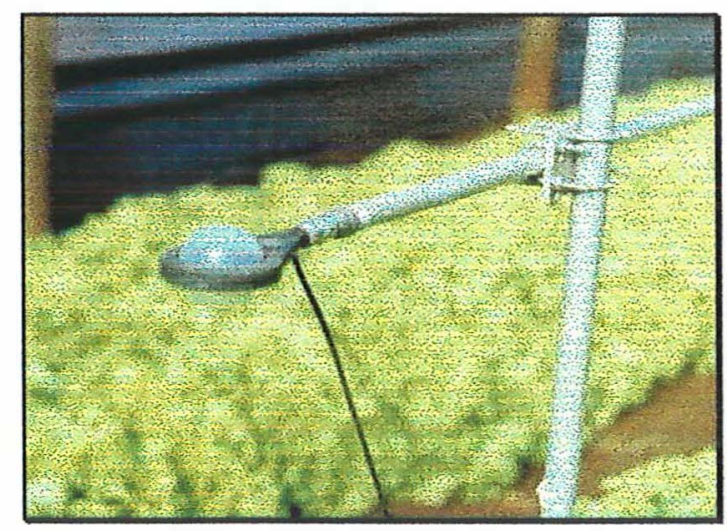

Figura 14 - Saldo radiômetro instalado sobre a alface, a 1,0 m de altura, no interior do ambiente protegido. 
O fluxo de calor sensível no solo foi medido a partir de duas placas (modelo HFT-3) instaladas a uma distância de 2,0 m da base do aparelho e a 1,0 m uma da outra, na profundidade de $0,08 \mathrm{~m}$. As placas apresentavam sensibilidade de 36 $\mathrm{W} \cdot \mathrm{m}^{-2} \cdot \mathrm{mV}^{-1}$ e seus valores foram monitorados através de termopares de solo, de cromelconstantan (modelo TCAV). Os termopares de solo foram instalados, acima das placas de solo, nas profundidades 0,02 e $0,06 \mathrm{~m}$. Na Figura 15 observam-se uma placa de fluxo de calor solo e um par de termômetros de solo.

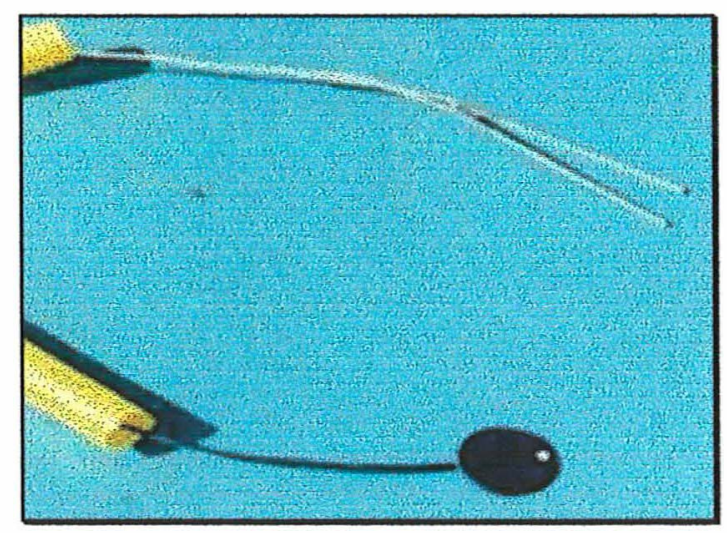

Figura 15 - Placa de fluxo de calor no solo e termopares de solo, instalados sob a alface, no interior do ambiente protegido.

Foram adicionados ao SRB sensores para medida da temperatura e umidade relativa do ar, a 2,0 m de altura da superfície do solo. O sensor utilizado, modelo HMP35C, apresentava, segundo o fabricante, acurácia de $\pm 0,1{ }^{\circ} \mathrm{C}$ para a temperatura do ar e $\pm 3 \%$ para a umidade relativa do ar (Figura 16 ).

Tentou-se medir a velocidade e direção do vento, no interior do ambiente protegido, com um anemômetro de canecas, modelo $014 \mathrm{~A}$, cujo valor de partida era de $0,2 \mathrm{~m} . \mathrm{s}^{-1}$ (Figura 17). Entretanto, como poderá ser observado no tópico 3, os resultados não foram adequados devido ao elevado valor de partida do sensor para as condições de ambiente protegido, sendo posteriormente desconectado do sistema de aquisição de 
dados para liberar canais e memória. Em conseqüência, optou-se por estimar a velocidade do vento, no interior do ambiente protegido, como $5 \%$ da velocidade externa, conforme proposição de Prados (1986).

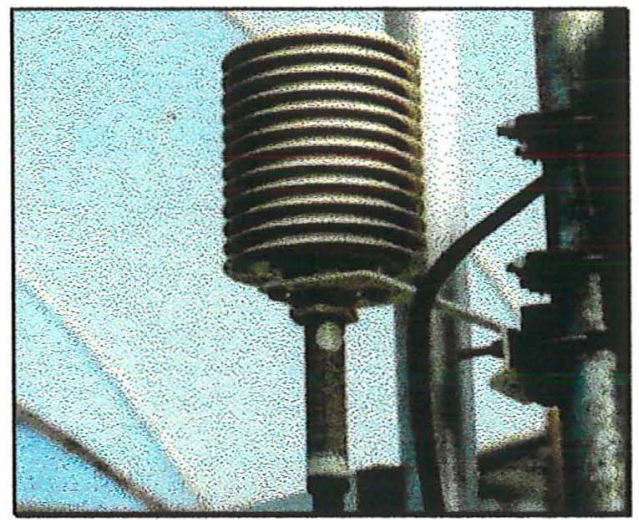

Figura 16 - Sensor de temperatura e umidade relativa do ar instalado a 2,0 m de altura, no interior do ambiente protegido.



Figura 17 - Sensores de velocidade e direção do vento instalados a 2,0 $\mathrm{m}$ de altura, no interior do ambiente protegido.

O SRB era alimentado por uma bateria de $12 \mathrm{~V}$ e $70 \mathrm{~A}$, e um painel solar, modelo MSX10, que proporcionaram um adequado suprimento de energia para o sistema nos dois períodos de cultivo, mesmo no mês de julho, quando ocorreram baixos valores diários de radiação, principalmente no ambiente protegido. 
Visando ao adequado registro das condições micrometeorológicas por parte do SRB realizou-se, antes do primeiro cultivo, em uma área a céu aberto, plantada com grama batatais, a comparação dos valores da evapotranspiração de referência estimados pelo SRB, utilizado no experimento, com os estimados por um segundo SRB (Figura 18) e os medidos por um lisímetro de pesagem. Os resultados dessa análise encontram-se nos Anexos 4 e 5, tendo sido observado excelente exatidão entre os dois SRB, e entre o SRB e o lisímetro de pesagem.

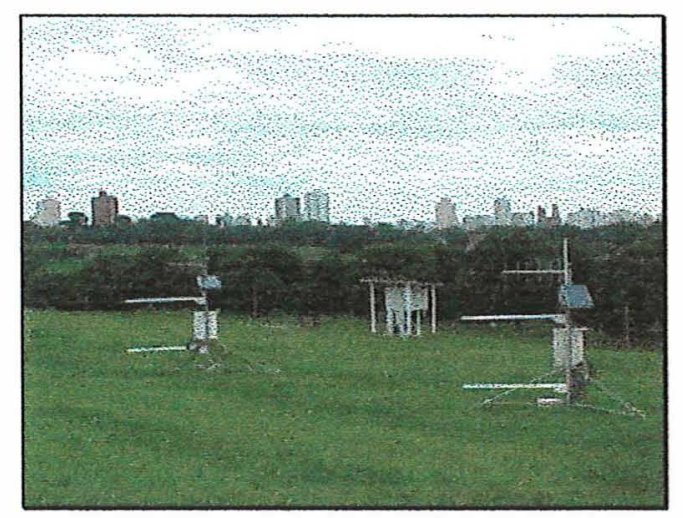

Figura 18 - Sistemas automáticos de medição da razão de Bowen instalados na estação meteorológica.

Os dados obtidos a cada segundo, nos diversos sensores do SRB, eram alocados na memória intermediária do sistema de aquisição de dados, e a cada 20 minutos eram gerados valores médios, armazenados na memória final do sistema (Figura 19). O sistema gerava dois relatórios de dados, sendo um denominado 110 , que continha as seguintes informações: dia Juliano, horário correspondente, temperatura de referência (obtida no interior do sistema de aquisição de dados), do ar, do ponto de orvalho e pressão parcial do vapor, sendo as três últimas nas duas alturas escolhidas, 1,25 e 0,25 m (Anexo 6). O outro relatório, denominado 237, continha além das informações sobre dia Juliano e horário correspondente, os valores médios para cada 20 minutos da radiação líquida, dos dois fluxos de calor no solo, da umidade relativa e da temperatura do ar, a 2,0 m de altura, e do peso do lisímetro (Anexo 7). 


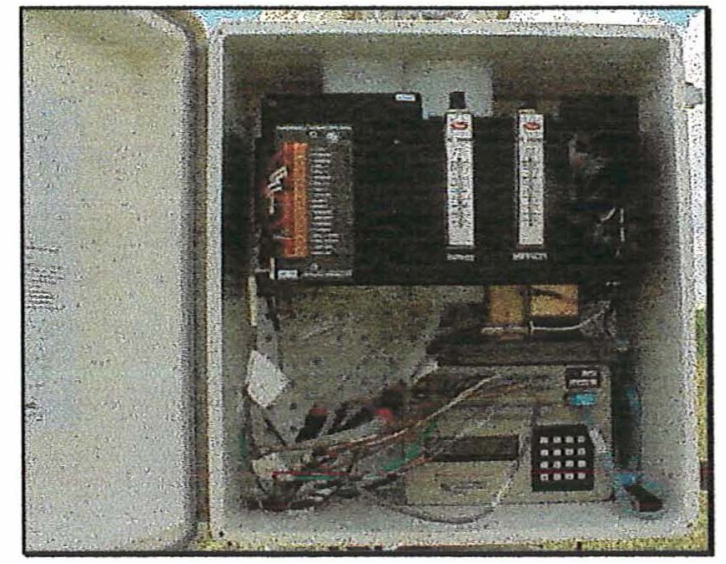

Figura 19 - Painel de controle e sistema de aquisição de dados do SRB.

Os relatórios com os valores médios dos diferentes elementos meteorológicos observados eram coletados semanalmente através do sistema de transmissão via rádio. O sistema era constituído de um radiotransmissor e antena, instalados no sistema razão de Bowen, e de um rádio receptor e computador, instalados a aproximadamente $1500 \mathrm{~m}$ da área experimental (Figura 20).

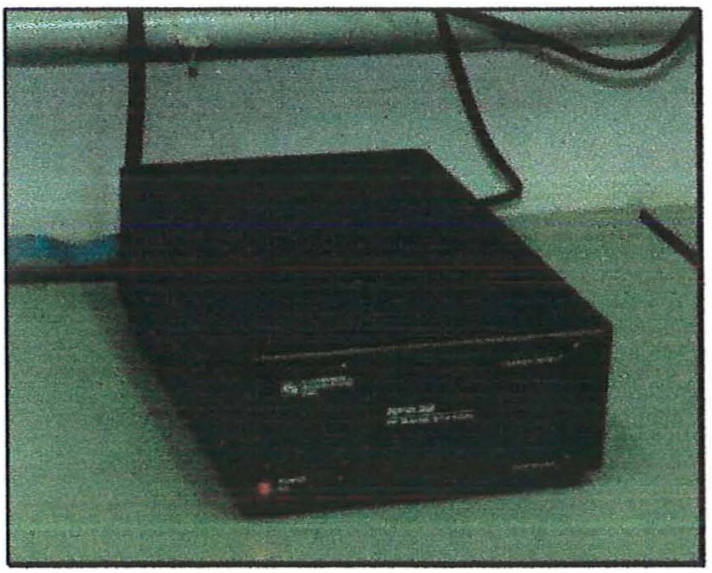

Figura 20 - Rádio receptor instalado a, aproximadamente, $1500 \mathrm{~m} \mathrm{da}$ área experimental. 
Uma vez disponibilizados no computador, os dados eram analisados a partir do software "Split" que separava os dados originários dos dois relatórios (110 e 237). Após a separação, os dados eram transportados para uma planilha do aplicativo Microsoft Excel, para cálculo do balanço de energia e comparações diversas com os dados obtidos na estação meteorológica, que distava aproximadamente $50 \mathrm{~m}$ do ambiente protegido.

No cálculo da razão de Bowen e do balanço de energia utilizam-se as seguintes informações: dia Juliano, horário correspondente, temperatura do ar, em ${ }^{\circ} \mathrm{C}$, a $1,25 \mathrm{~m}\left(\mathrm{~T}_{1,25}\right)$, temperatura do ar, em ${ }^{\circ} \mathrm{C}$, a $0,25 \mathrm{~m}\left(\mathrm{~T}_{0,25}\right)$, gradiente de temperatura do ar, em ${ }^{\circ} \mathrm{C},\left(\Delta \mathrm{T}=\mathrm{T}_{0,25}-\mathrm{T}_{1,25}\right)$, temperatura do ponto de orvalho, em ${ }^{\circ} \mathrm{C}$, a $1,25 \mathrm{~m}$ $\left(\mathrm{TO}_{1,25}\right)$, pressão parcial do vapor, em $\mathrm{kPa}$, a $1,25 \mathrm{~m}\left(\mathrm{ea}_{1,25}\right)$, temperatura do ponto de orvalho, em ${ }^{\circ} \mathrm{C}$, a $0,25 \mathrm{~m}\left(\mathrm{TO}_{0,25}\right)$, pressão parcial do vapor, em $\mathrm{kPa}$, a $0,25 \mathrm{~m}\left(\mathrm{ea}_{0,25}\right)$, radiação líquida, em W. $\mathrm{m}^{-2}$ e fluxos 1 e 2 de calor sensível no solo, em W. $\mathrm{m}^{-2}$.

A estimativa da razão de Bowen, $\beta$, era calculada através da equação:

$$
\beta=\gamma \cdot \frac{\Delta T}{\left(e a_{0,25}-e a_{1,25}\right)}
$$

em que $\gamma$ era o coeficiente psicrométrico, cujo valor assumido era de $0,0626 \mathrm{kPa} .{ }^{\circ} \mathrm{C}^{-1}$.

$\mathrm{O}$ valor assumido para o coeficiente psicrométrico foi resultante da seguinte equação:

$$
\gamma=\frac{P \cdot c p}{\lambda \cdot \varepsilon}
$$

em que $\mathrm{P}$, pressão atmosférica, $\mathrm{cp}$, calor específico do ar à pressão constante, $\lambda$, calor latente de evaporação, $\varepsilon$, a razão entre a massa molecular do vapor d'água e a massa molecular do ar, foram considerados, respectivamente, iguais a $94,93 \mathrm{kPa}, 1005 \mathrm{~J}_{\mathrm{kg}}{ }^{-1}$, $2450000 \mathrm{~J} \cdot \mathrm{kg}^{-1}$ e 0,622 . 
O fluxo de calor latente, em W. $\mathrm{m}^{-2}$, foi então estimado através da equação:

$$
\mathrm{LE}=\frac{R n-\left(\frac{G_{1}+G_{2}}{2}\right)}{(1+\beta)}
$$

Considerou-se positivo o fluxo que fluía da atmosfera ou do subsolo para a superficie, e negativo quando fluía da superficie para a atmosfera ou subsolo. Entretanto, matematicamente para que tais considerações fossem aplicadas corretamente, no cálculo do fluxo de calor latente, fez-se necessário adicionar o sinal negativo junto ao saldo de radiação. Devido à convenção adotada pelo SRB, fez-se também necessário adicionar o sinal negativo aos valores obtidos com os fluxos de calor no solo. Assim sendo, a eq. (16) tornou-se:

$$
\mathrm{LE}=\frac{-R n-\left(\frac{-G_{1}-G_{2}}{2}\right)}{(1+\beta)}
$$

O fluxo de calor sensível, $H$, em W. $\mathrm{m}^{-2}$, foi estimado através da seguinte equação:

$$
H=\beta . L E
$$

A estimativa da evapotranspiração, em mm, para cada intervalo de tempo de 20 min foi então calculada pela eq. (19):

$$
\operatorname{ETc}\left(\mathrm{mm} .20 \mathrm{~min}^{-1}\right)=\frac{L E .20 .60}{(2.450 .000)}
$$


em que as constantes 20, tempo em minutos, e 60, quantidade de segundos em um minuto, foram utilizadas para ajustar a escala de tempo. A constante 2.450.000, representava o valor do calor latente de evaporação da água, em J por $\mathrm{kg}$ a $20^{\circ} \mathrm{C}$, e foi utilizada para converter o fluxo de calor latente em água evapotranspirada.

Na estimativa da evapotranspiração da cultura consideraram-se somente os valores diários conforme recomendação de Heilman \& Brittin (1989), Cellier \& Olioso al. (1993) e Kustas et al. (1996). Foram também descartadas as estimativas de ETc originárias de valores razão de Bowen entre $-0,7$ e $-1,3$, consoante sugestão de Uhland et al. (1996).

Enfatiza-se que se considerou período diurno aquele compreendido entre 6 e 18 horas. A soma dos totais de evapotranspiração, a cada 20 minutos, ocorridos no período citado, excetuando-se as condições expostas no parágrafo anterior, correspondeu à estimativa da evapotranspiração diária.

Ressalta-se, ainda, que semanalmente foram feitas manutenções no SRB, em conformidade com o recomendado pelo fabricante, através de calibrações no higrômetro, limpeza dos termopares de cromel-constantan, das mangueiras de sucção, do painel solar e da estrutura de sustentação e troca, quinzenal, dos filtros de papel colocados nos pontos de suç̧ão do ar ambiente.

\subsection{Evapotranspiração de referência}

Estimou-se a evapotranspiração de referência, dentro e fora do ambiente protegido, pelo método de Penman-Monteith. A estimativa da evapotranspiração de referência visou à obtenção do coeficiente de cultivo e à análise da sua variação dentro e fora do ambiente protegido, e foi realizada a partir da equação proposta por Monteith (1965):

$$
\lambda \mathrm{E}=\frac{s \cdot(R n-G)+M \rho \cdot c p \cdot \frac{\Delta e}{r a}}{s+\gamma\left(1+\frac{r c}{r a}\right)}
$$


em que $\lambda E$ é o calor latente de evapotranspiração, em W.m $\mathrm{m}^{-2}$; $\mathrm{Rn}$ a radiação líquida, em W. $\mathrm{m}^{-2}$; G o fluxo de calor sensível no solo, em W. $\mathrm{m}^{-2} ; \rho$ a massa específica do ar atmosférico, $1,26 \mathrm{~kg} \cdot \mathrm{m}^{-3} ; \mathrm{C}_{\mathrm{p}} \mathrm{o}$ calor específico do ar à pressão constante, $1,005 \mathrm{MJ} \cdot \mathrm{kg}^{-}$ ${ }^{1} . \mathrm{C}^{-1} ; \Delta \mathrm{e}$ o déficit de pressão de vapor d'água a temperatura do ar (es - ea), em kPa; rc a resistência da cobertura vegetal, em $\mathrm{s} . \mathrm{m}^{-1}$; ra a resistência aerodinâmica à transferência de calor sensível e calor latente de evaporação, em s. $\mathrm{m}^{-1} ; \gamma$ o coeficiente psicrométrico, adotou-se $0,0626 \mathrm{kPa}^{\circ} \mathrm{C}^{-1}$; s a inclinação da tangente à curva de pressão de saturação de vapor d'água, no ponto dado pela temperatura do ar, em $\mathrm{kPa} .{ }^{\circ} \mathrm{C}^{-1}$.

$\mathrm{O}$ coeficiente $\mathrm{M}$ ajusta a escala de tempo, visto que ra é dada em $\mathrm{s} . \mathrm{m}^{-1}$, portanto, para $20 \min \mathrm{M}=1200$. $\mathrm{O}$ valor da tangente à curva de pressão de saturação de vapor d'água, s, foi calculado pela eq. (22):

$$
\mathrm{s}=\frac{4098 e s}{(T+237,3)^{2}}
$$

em que es é a pressão de saturação do vapor, em $\mathrm{kPa}$, e $\mathrm{T}$ a temperatura do $\mathrm{ar}$, em ${ }^{\circ} \mathrm{C}$. No calculo da pressão de saturação do vapor, es em $\mathrm{kPa}$, foi utilizada a equação de Tetens:

$$
\text { es }=0,6108 \cdot 10^{\left(\frac{7,5 \cdot T}{237,3+T}\right)}
$$

A pressão parcial do vapor, ea em $\mathrm{kPa}$, foi calculada pela eq. (24):

$$
\mathrm{ea}=\frac{e s \cdot U R}{100}
$$

em que UR é a umidade relativa do ar, em \%. 
Assumiu-se, em concordância com a parametrização proposta pela $\mathrm{FAO}$, a eq. (25) para cálculo da resistência aerodinâmica, ra em s.m ${ }^{-1}$ :

$$
r a=\frac{208}{u_{2,0 m}}
$$

em que $\mathrm{u}_{2,0 \mathrm{~m}}$ é a velocidade do vento a $2,0 \mathrm{~m}$ de altura, em $\mathrm{m} . \mathrm{s}^{-1}$. Do mesmo modo, a relação $\frac{r c}{r a}$ foi quantificada através da eq. (26).

$$
\frac{r c}{r a} \cong 0,33 \cdot u_{2,0 m}
$$

\subsection{Elementos meteorológicos externos}

Os elementos meteorológicos externos ao ambiente protegido foram obtidos a partir de uma estação meteorológica automatizada instalada a aproximadamente $50 \mathrm{~m}$ do ambiente protegido (Figura 21). A estação possui, dentre outros sensores, termohigrômetro (modelo HMP35C), saldo radiômetro (modelo Q7.1 Net Radiometer-REBS; espectro de 0,25 a $60 \mu \mathrm{m}$ ), placas de fluxo de calor no solo (modelo HFT-3), anemômetro de canecas (modelo 014 A, com valor de partida de 0,2 $\mathrm{m} . \mathrm{s}^{-1}$ ), piranômetro (modelo LI200X-L) e pluviômetro (modelo CS700-L).

Os dados obtidos na estação meteorológica foram armazenados em um sistema de aquisição de dados, modelo CR10 com multiplexador, e semanalmente eram coletados via rádio, gerando o relatório de dados denominado 101, com o qual selecionavam-se as seguintes informações: dia Juliano, horário, temperatura do ar, umidade relativa, velocidade do vento, radiação global, radiação líquida, nível de água no tanque e precipitação (Anexo 8). 


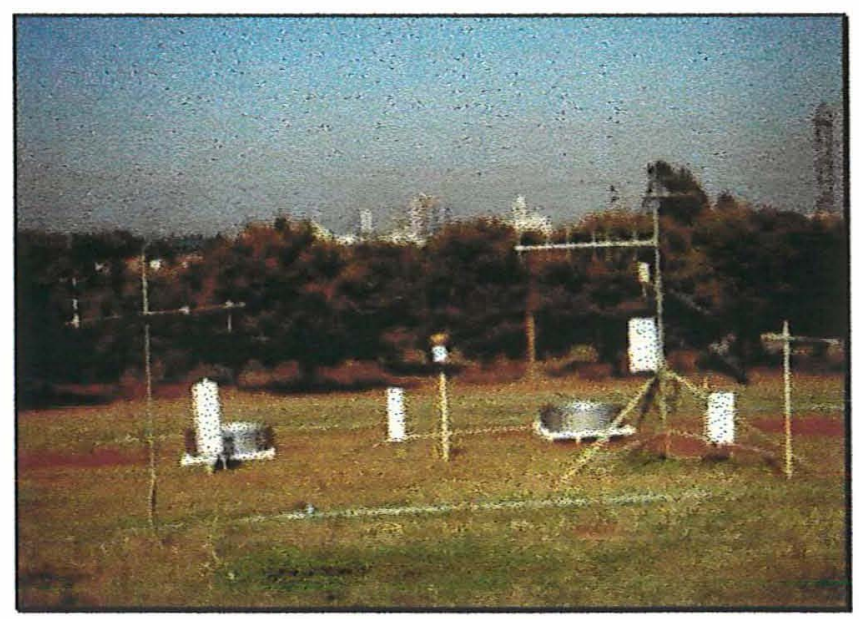

Figura 21 - Estação meteorológica automatizada

Os dados obtidos ao longo de cada dia de cultivo, dentro e fora do ambiente protegido, foram colocados em planilhas do aplicativo Microsoft Excel, totalizando 31 planilhas no primeiro ciclo experimental, e 43 no segundo. A partir dessas planilhas foram realizadas diversas comparações entre os elementos meteorológicos obtidos dentro e fora do ambiente protegido. Ressalta-se que, por não haver piranômetro instalado no interior do ambiente protegido, a radiação solar incidente foi estimada como inferior em $20,3 \%$ à registrada exteriormente, conforme resultados obtidos por Sentelhas et al. (1997).

\subsection{Coeficiente de cultivo}

Estimou-se o coeficiente de cultivo da alface $(\mathrm{Kc})$, para os dois períodos, através da relação entre a evapotranspiração da cultura medida no lisímetro de pesagem (ETc) e a evapotranspiração de referência (ETo), estimada pela equação de PenmanMonteith. Os coeficientes de cultivo foram apresentados por valores médios para cada 5 dias, ou seja, por qüinqǘdio e por fase fisiológica. Ressalta-se que, como a evapotranspiração da cultura compreendeu o somatório das variações de peso no lisímetro durante o período diurno, considerou-se, também, somente o período diurno na quantificação da evapotranspiração de referência. 


\subsection{Perfil vertical de temperatura e umidade atmosférica}

Visando a medir diferenças verticais de temperatura e umidade, no ambiente protegido, construiu-se a diferentes alturas psicrômetros constituídos de termopares, seco e úmido, de cobre-constantan (Figura 22). O termômetro úmido era constituído além do termopar de uma gaze embebida em água destilada, colocada em um pequeno recipiente, conforme procedimento utilizado por Cunha et al. (1996). O recipiente era semanalmente reabastecido com água destilada.

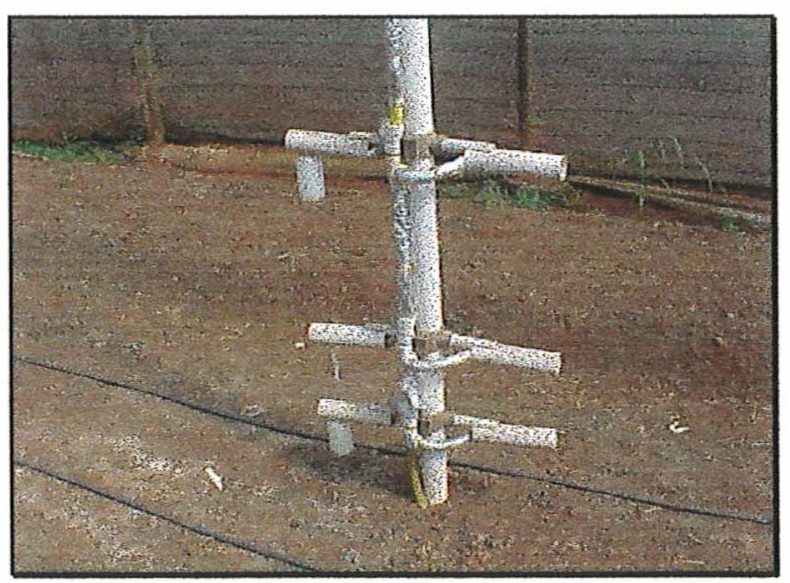

Figura 22 - Visão parcial do perfil psicrométrico instalado no interior do ambiente protegido, sobre o canteiro central.

Os psicrômetros foram instalados em microabrigos de PVC branco, nos níveis correspondentes a 0,$25 ; 0,50 ; 1,00$ e $2,0 \mathrm{~m}$, acima da cultura. Os termopares foram protegidos por conduítes e papel alumínio, visando a minimizar trocas térmicas com o meio. Os dados de temperatura dos bulbos secos e úmidos foram armazenados em um sistema de aquisição de dados, modelo CR-10. O relatório de saída de dados do sistema, identificado como 101, encontra-se exemplificado no Anexo 9. 


\subsection{Variáveis fisiológicas}

Foram colhidas, em intervalos semanais, cinco plantas da bordadura, visando a estimar o índice de área foliar e a matéria seca total. As folhas das plantas semanalmente colhidas eram destacadas e medidas num integrador de área foliar (Modelo 3100, Licor-Inc), tendo a média das cinco plantas, em $\mathrm{m}^{2}$, constituído a área foliar total da respectiva semana. $\mathbf{O}$ índice de área foliar era, então, assim estimado:

$$
\mathrm{IAF}_{\mathrm{i}}=\mathrm{AF} \mathrm{F}_{\mathrm{i}} \cdot \mathrm{n}^{\circ} \text { plantas por } \mathrm{m}^{2}
$$

em que $\mathrm{IAF}_{\mathrm{i}}$ era o índice de área foliar na semana $\mathrm{e}_{\mathrm{i}} \mathrm{AF}_{\mathrm{i}}$ a área foliar total na semana ${ }_{\mathrm{i}}$. $\mathrm{O}$ número de plantas por $\mathrm{m}^{2}$ era 16 (espaçamento $0,25 \mathrm{~m} \mathrm{x} \mathrm{0,25} \mathrm{m).}$

Após medição, as folhas das respectivas plantas eram acrescidas dos seus restos e levadas à estufa por 48 horas em uma temperatura de $80^{\circ} \mathrm{C}$. Após secagem eram pesadas em uma balança de precisão, tendo a média de peso das cinco amostras constituído o peso da matéria seca na coleta ${ }_{\mathrm{i}}$.

$\mathrm{Na}$ estimativa da taxa de crescimento da cultura (TCC, em g.dia ${ }^{-1}$ ) utilizouse a seguinte equação:

$$
\mathrm{TCC}_{\mathrm{i}, \mathrm{i}-1}=\frac{M s_{i}-M s_{i-1}}{t_{i}-t_{i-1}}
$$

em que Ms era a matéria seca, em g, t o tempo, em dias após transplantio, e i-1 e $\mathrm{i}$ duas coletas consecutivas.

A taxa de crescimento relativo (TCR, em g.dia ${ }^{-1}$ ) foi estimada pela fórmula:

$$
\mathrm{TCR}_{\mathrm{i}, \mathrm{i}-1}=\frac{\operatorname{LnM}_{\mathrm{i}}-\operatorname{LnM} s_{i-1}}{t_{i}-t_{i-1}}
$$


$\mathrm{Na}$ estimativa da taxa de assimilação líquida, TAL $\left(\mathrm{g} \cdot \mathrm{dm}^{-2} \cdot \mathrm{dia}^{-1}\right)$, utilizouse a eq. (29):

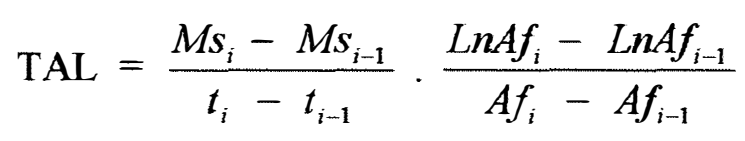

Findos os experimentos, identificaram-se as fases de crescimento, inicial intermediária e final, com o auxilio dos índices fisiológicos IAF, TTC e TCR e TAL.

\subsection{Análise estatística}

Os elementos meteorológicos obtidos dentro e fora do ambiente protegido, saldo de radiação, temperatura do ar, umidade atmosférica e evapotranspiração de referência, foram comparados pelas variações ao longo dos dias e dos períodos de cultivos. Correlacionou-se, ainda, cada elemento meteorológico citado, com a finalidade de se obterem as relações entre os valores internos e externos.

Os valores da evapotranspiração da cultura (ETc) estimados pelo sistema automático da Razão de Bowen foram comparados com os medidos pelo lisímetro de pesagem, pelo coeficiente de determinação $\left(\mathrm{r}^{2}\right)$ e pelo índice de concordância de Wilmott (id). $\mathrm{O}$ valor de $\mathrm{r}^{2}$ varia de 0 a 1,0 e quanto mais próximo o valor for de 1,0 maior é a precisão entre os dados correlacionados. O índice de concordância proposto por Willmott (1981) é variável de 0 a 1,0 e quanto mais próximo o seu valor for de 1,0, maior é a exatidão entre os valores medidos e estimados. $O$ índice de Wilmott é calculado através da seguinte equação:

$$
\mathrm{id}=1-\frac{\Sigma(P i-O i)^{2}}{\Sigma[(P i-\bar{O})+(O i-\bar{O})]^{2}}
$$

em que $\mathrm{P}$ é a evapotranspiração estimada pelo SRB $(\mathrm{mm}), \mathrm{O}$ a evapotranspiração observada no lisímetro (mm) e $\bar{O}$ a evapotranspiração observada média (mm). 


\section{RESULTADOS E DISCUSSÃO}

\subsection{Efeitos da cobertura plástica sobre os elementos meteorológicos}

\subsubsection{Radiação}

Na Figura 23 são mostradas as variações ao longo do dia do saldo de radiação sobre a alface, no interior do ambiente protegido, e sobre grama batatais, na estação meteorológica, aos $16 \mathrm{DAT}_{1}$ (16 dias após o transplantio, no primeiro cultivo da alface) e $22 \mathrm{DAT}_{2}$ (22 dias após o transplantio, no segundo cultivo). As figuras foram construídas a partir de valores médios para cada 20 minutos, e os dias relatados foram escolhidos por representarem o meio de cada cultivo.

Observa-se que, ao longo do período noturno, o saldo de radiação na estação meteorológica foi inferior ao registrado dentro do ambiente protegido, principalmente aos $16 \mathrm{DAT}_{1}$, e isso ocorreu devido ao fato de que em condições de céu aberto a radiação terrestre é mais facilmente transmitida para a atmosfera, possibilitando saldos noturnos menores. Em oposição, a radiação terrestre no ambiente protegido é parcialmente absorvida e refletida pela cobertura plástica, fazendo com que um menor percentual da radiação terrestre seja transmitido para a atmosfera. Ressalta-se que o plástico da cobertura, PEBD, apresenta elevada transparência à radiação de ondas longas (Tapia, 1981; Robledo de Pedro \& Vicente, 1988), porém não total. Além disso, a cobertura plástica tende a emitir radiação em direção ao solo, formando um dipólo emissivo (solo-plástico), tornando menos negativo o saldo de radiação durante a noite dentro do ambiente protegido. 
(a)

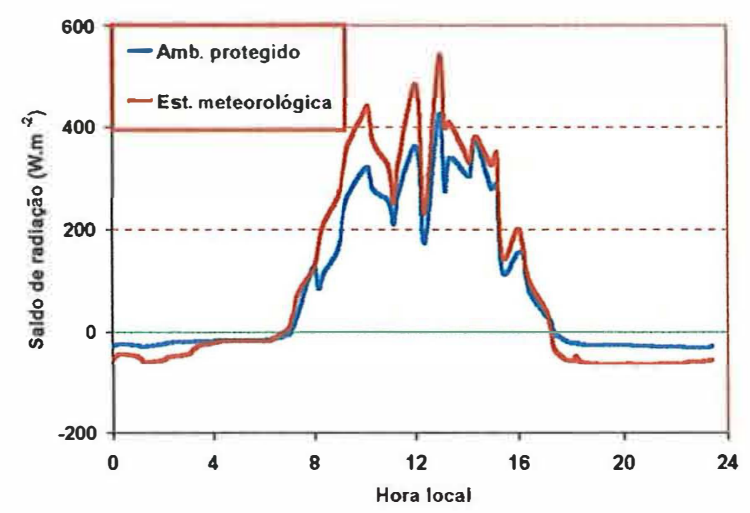

(b)

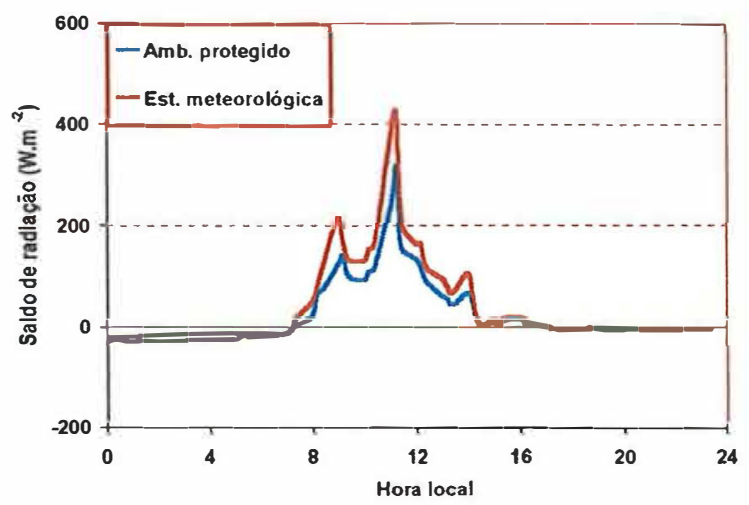

Figura 23 - Variação ao longo do dia do saldo de radiação medido no interior do ambiente protegido, sobre a alface, e na estação meteorológica, sobre grama batatais, aos 16 DAT no primeiro cultivo (a) e aos 22 DAT no segundo cultivo (b), em Piracicaba, SP, no ano de 2000.

Ao longo do período diurno o saldo de radiação dentro do ambiente protegido foi inferior ao registrado externamente na estação meteorológica. Isto deveuse à menor incidência de radiação solar no interior do ambiente protegido, devido à sua reflexão e absorção por parte do plástico. Comentário semelhante fizeram Seeman (1979), Prados (1986), Kurata (1990), Farias et al. (1994), Camacho et al. (1995), Sentelhas et al. (1997) e Folegatti et al. (1997).

No interior do ambiente protegido há um aumento da radiação solar difusa em comparação com o ambiente externo, proporcionado pela reflexão do plástico. $\mathrm{O}$ aumento da radiação difusa foi observado por Martinez Garcia (1978), Prados (1986), Farias et al. (1993b) e Camacho et al. (1995). Há também aumento de radiação de ondas longas, decorrente da emissão radiativa da cobertura plástica (Grafiadelis, 1985; Mahrer, 1991). Apesar desses aumentos de incidência de radiação na superfície, observou-se durante o período diurno um menor no saldo de radiação no interior do ambiente protegido. Isto ocorreu devido ao fato de os aumentos de incidência de radiação difusa e de ondas longas não terem sido suficientes para compensar a redução da incidência de radiação solar direta e, assim sendo, o saldo de radiação no interior do ambiente 
protegido foi inferior ao ocorrido externamente. Enfatiza-se que, um outro fator que também pode ter contribuído para o registro de saldo de radiação diferenciado, dentro e fora do ambiente protegido, é o valor do albedo das culturas, ou seja, a alface e a grama podem ter refletido a radiação solar em intensidades diferentes, contribuindo para aumentar as diferenças dos valores registrados nos dois ambientes.

O total diário de saldo de radiação disponível no interior do ambiente protegido representou $85,76 \%$ e $70,49 \%$ do total externo, respectivamente, aos 16 $\mathrm{DAT}_{1}$ e $22 \mathrm{DAT}_{2}$ (Anexos 10 e 11). Estão plotados na Figura 24 os totais diários do saldo de radiação dentro e fora do ambiente protegido, para o primeiro (a) e o segundo (b) cultivos. Observou-se que, no primeiro cultivo, os saldos diários de radiação, dentro e fora do ambiente protegido, tenderam a decrescer com o desenvolvimento da cultura, desde valores superiores a $9 \mathrm{MJ} \cdot \mathrm{m}^{-2} \cdot \mathrm{dia}^{-1}$ até valores inferiores a $4 \mathrm{MJ} \cdot \mathrm{m}^{-2} \cdot \operatorname{dia}^{-1}$. A média diária do saldo de radiação dentro e fora do ambiente protegido foram, respectivamente, 7,78 e 9,13 MJ.m ${ }^{-2} \cdot$ dia $^{-1}$ (Anexo 10). Em oposição, como é característico da estação do inverno, o segundo período de cultivo da alface apresentou totais menores, com valores médios de 4,93 e 6,10 MJ.m ${ }^{-2} \cdot$ dia $^{-1}$, respectivamente, dentro e fora do ambiente protegido (Anexo 11). Em conseqüência, enquanto no primeiro período de cultivo foram necessários 31 dias, do transplantio ao início da colheita, no segundo perdurou por 43 dias.

Na Figura 25 podem-se observar as correlações das radiações líquidas obtidas dentro e fora do ambiente protegido, ao longo do primeiro (a) e do segundo (b) cultivos. No primeiro cultivo o total diário do saldo de radiação no interior do ambiente protegido representou $85,22 \%$ do registrado na estação $\left(r^{2}=0,850\right)$, e no segundo o percentual foi reduzido para $80,81 \%\left(r^{2}=0,898\right)$. O menor percentual no segundo período de cultivo deveu-se à maior inclinação dos raios solares que atingiam a área experimental, o que deve ter contribuído para um maior albedo da cobertura plástica e, conseqüentemente, uma menor incidência relativa de radiação solar no interior do ambiente protegido. Esse aumento do albedo do PEBD, com o aumento da inclinação solar, foi observado por Martin \& Robledo (1981), Grafiadelis (1985), Robledo de Pedro $\&$ Vicente(1988) e Camacho et al. (1995). 
(a)

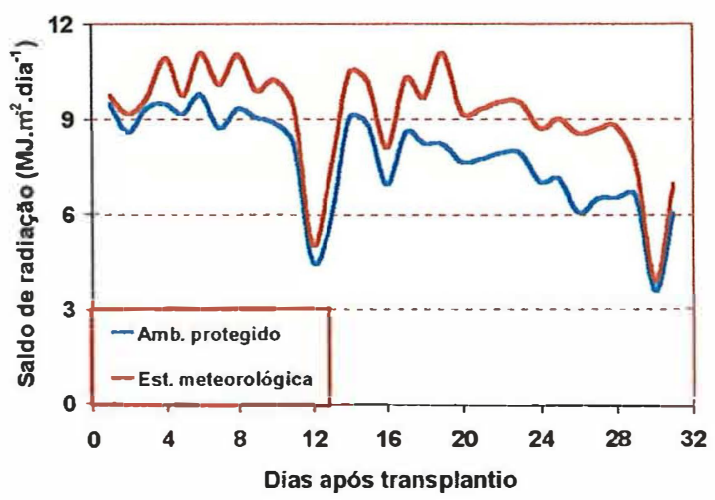

(b)

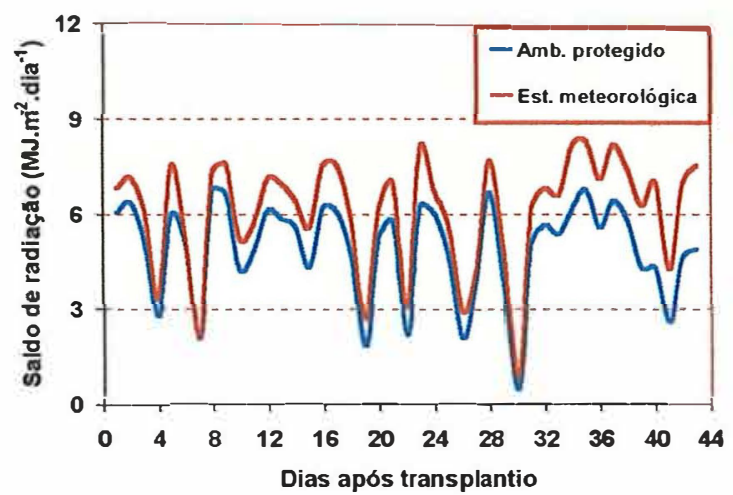

Figura 24 - Variação do total diário do saldo de radiação, medido no interior do ambiente protegido, sobre a alface, e na estação meteorológica, sobre grama batatais, no primeiro (a) e no segundo (b) cultivos, em Piracicaba, SP, no ano de 2000.

(a)

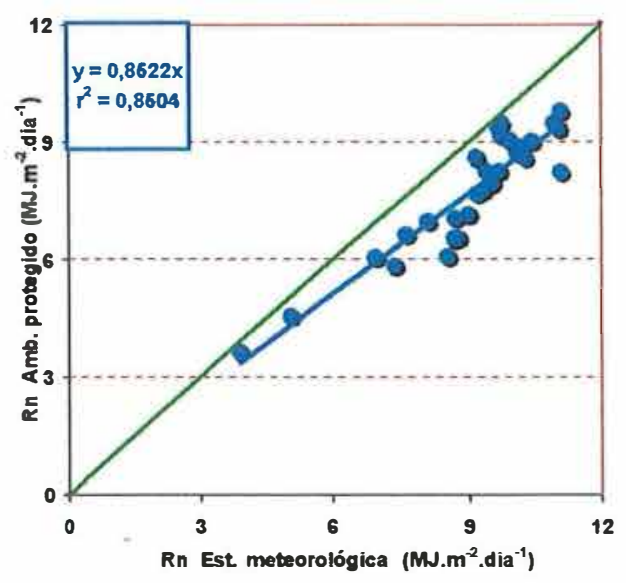

(b)

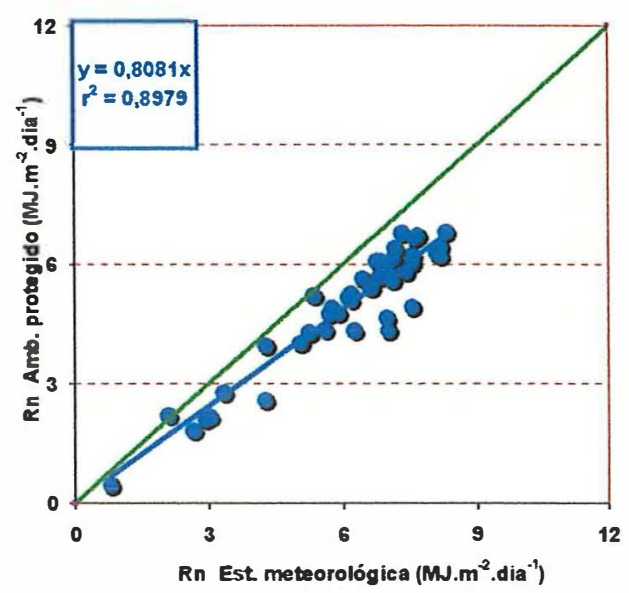

Figura 25 - Correlação entre os saldos diários de radiação (Rn) medidos no interior do ambiente protegido, sobre a alface, e na estação meteorológica, sobre a grama, no primeiro (a) e no segundo (b) cultivos, em Piracicaba, SP, no ano de 2000. 
Na Figura 26 são mostradas as variações ao longo do dia do saldo de radiação, dentro do ambiente protegido, e da incidência externa da radiação solar global, aos $16 \mathrm{DAT}_{1}$ (a) e $22 \mathrm{DAT}_{2}$ (b). A incidência externa de radiação solar global à noite, em ambos os dias, foi igual a zero. Com o nascer do sol e conseqüente redução do ângulo zenital, a incidência dos raios solares foi aumentando até tornar-se máxima às 13:00 h aos $16 \mathrm{DAT}_{1}, 747,00 \mathrm{~W} \cdot \mathrm{m}^{-2}$, e às 11:20 h aos $22 \mathrm{DAT}_{2}, 603,6 \mathrm{~W} \cdot \mathrm{m}^{-2}$. Em seguida, apesar de algumas oscilações, principalmente aos $16 \mathrm{DAT}_{1}$, decresceu, atingindo novamente zero à noite. Os valores máximos do saldo de radiação foram de 424,82 e $314,80 \mathrm{~W} \cdot \mathrm{m}^{-2}$, para os respectivos dias. O total de radiação global incidente fora do ambiente protegido, aos $16 \mathrm{DAT} 1$, foi de $16,31 \mathrm{MJ} \cdot \mathrm{m}^{-2} \cdot \mathrm{dia}^{-1}$, ao passo que o saldo de radiação interno foi de 6,95 MJ.m $\mathrm{m}^{-2} \cdot \mathrm{dia}^{-1}$, representando 42,61 \% (Anexo 10). Aos $22 \mathrm{DAT}_{2}$ o total do saldo de radiação foi de 2,14 MJ.m $\mathrm{m}^{-2}$.dia ${ }^{-1}$, perfazendo 35,40\% da incidente externamente, 6,03 MJ.m $\mathrm{m}^{-2} \cdot \mathrm{dia}^{-1}$ (Anexo 11).

(a)

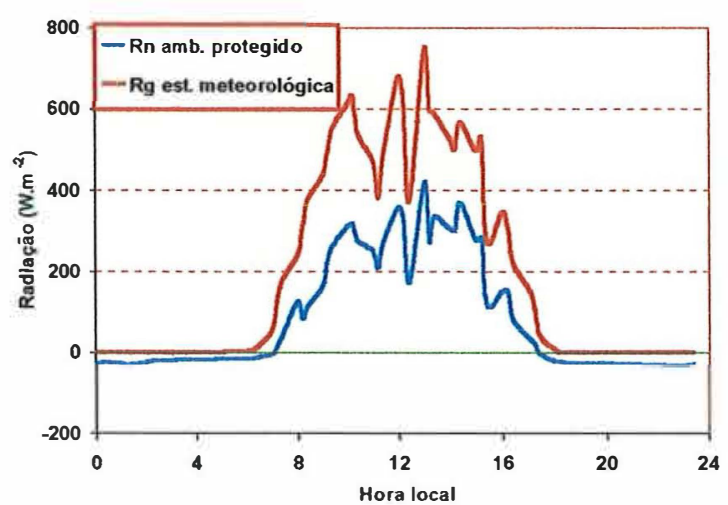

(b)

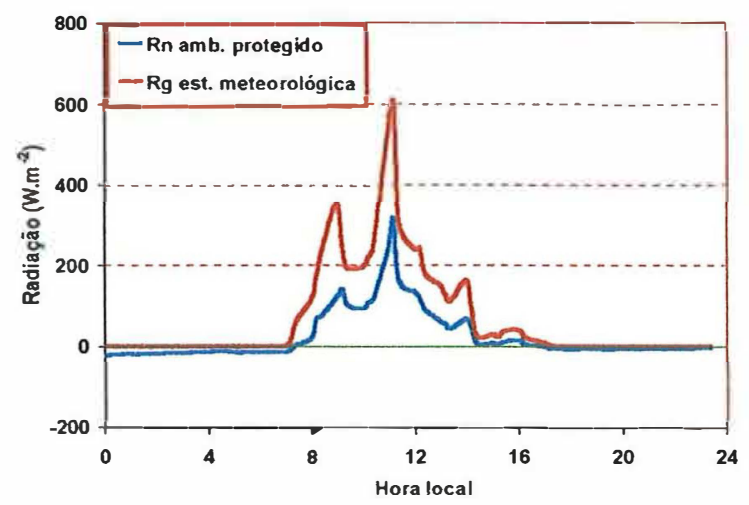

Figura 26 - Variação ao longo do dia do saldo de radiação (Rn), medido no interior do ambiente protegido, sobre a alface, e da radiação solar global $(\mathrm{Rg})$, medida na estação meteorológica, sobre grama batatais, aos 16 DAT no primeiro cultivo (a) e aos 22 DAT no segundo cultivo (b), em Piracicaba, SP, no ano de 2000 . 
Os resultados da correlação entre os totais diários do saldo de radiação obtidos, sobre a alface, dentro do ambiente protegido e da incidência externa de radiação solar global, no primeiro e no segundo cultivos, encontram-se na Figura 27 (a) e (b), respectivamente. Os totais diários do saldo de radiação, no primeiro período de cultivo, representaram 45,55\% $\left(\mathrm{r}^{2}=0,917\right)$ dos totais diários de radiação global medidos externamente. No segundo período de cultivo da alface esse percentual foi de $40,76 \%\left(\mathrm{r}^{2}\right.$ $=0,888)$. Em parte, esse menor percentual no segundo cultivo pode ser explicado pela maior inclinação dos raios solares, e pelo maior albedo da cobertura plástica, nesse período, proporcionando uma menor incidência relativa de radiação global no interior do ambiente protegido.

(a)

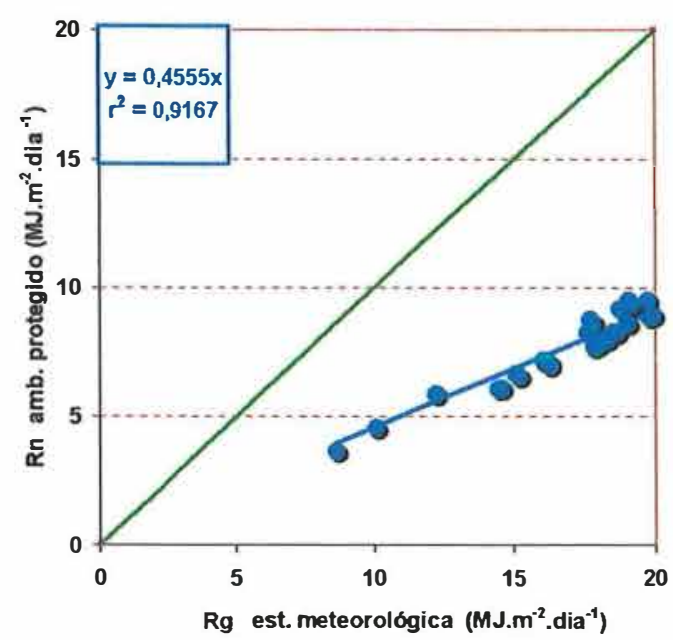

(b)

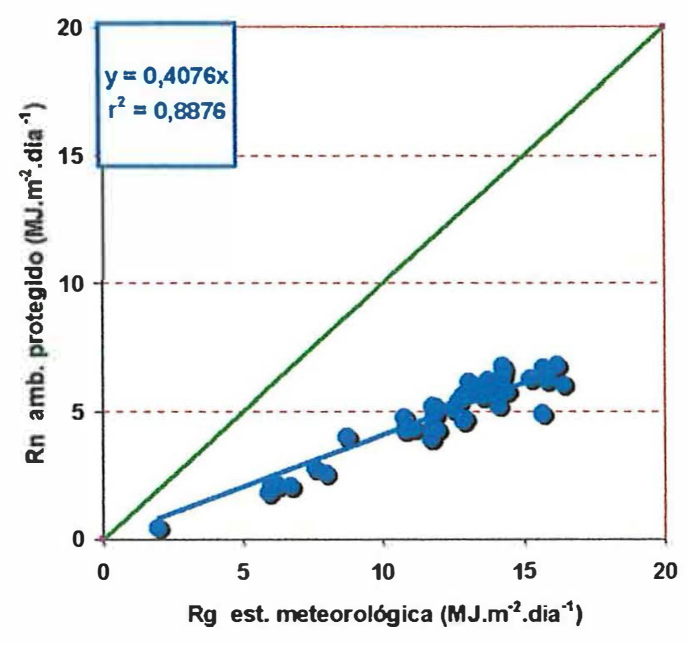

Figura 27 - Correlação entre os totais diários do saldo de radiação (Rn), medidos no interior do ambiente protegido sobre a alface, e de radiação solar global $(\mathrm{Rg})$, medidos na estação meteorológica sobre grama batatais, no primeiro (a) e no segundo (b) cultivos, em Piracicaba, SP, no ano de 2000. 


\subsubsection{Temperatura do ar}

As variações, ao longo do dia, da temperatura do ar dentro e fora do ambiente protegido aos $16 \mathrm{DAT}_{1}$ e $22 \mathrm{DAT}_{2}$ são mostradas na Figura 28. Nos dois dias no período diurno, das 9 às $15 \mathrm{~h}$, observaram-se maiores temperaturas no interior do ambiente protegido. Isso ocorreu porque, durante o período diurno, o ar aquecido tende, convectivamente, a se elevar dissipando calor para as camadas mais altas. Entretanto, no ambiente protegido, os movimento convectivos das camadas de ar são contidos pela cobertura plástica, ocorrendo o acúmulo do ar aquecido nas partes mais altas. Em conseqüência, há uma maior elevação de temperatura no interior do ambiente protegido. Em função disso, durante as horas próximas ao meio-dia, as temperaturas no interior do ambiente protegido são superiores às registradas externamente. Maiores temperaturas diurnas no interior do ambiente protegido também foram observadas por Tanaka \& Genta (1982), Villele (1989), Buriol et al. (1993), Farias et al. (1993a), Pezzopane (1994) e Scatolini (1996).

(a)

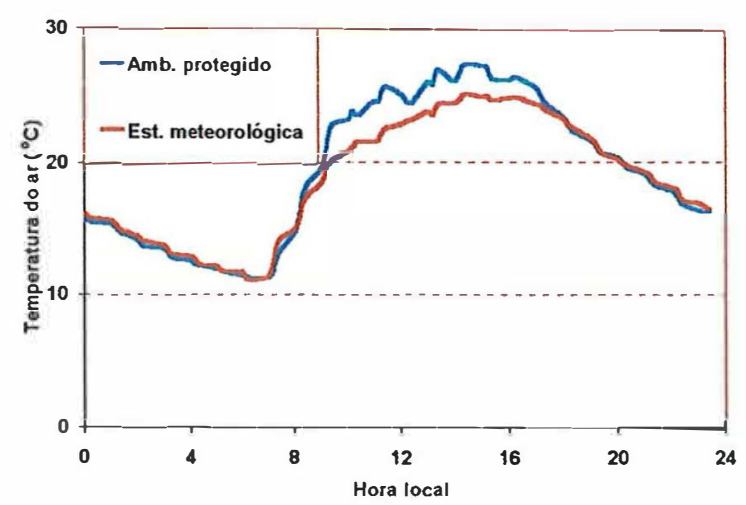

(b)

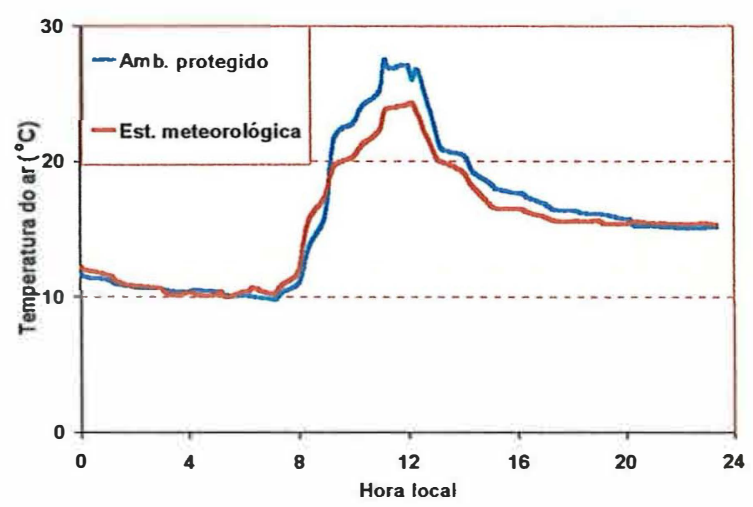

Figura 28 - Variação ao longo do dia da temperatura do ar medida, no interior do ambiente protegido e na estação meteorológica, aos 16 DAT no primeiro cultivo (a) e aos 22 DAT no segundo cultivo (b), em Piracicaba, SP, no ano de 2000 . 
Durante a noite, as temperaturas decresceram, sendo que no interior do ambiente protegido registraram-se valores semelhantes aos externos, às vezes inferiores. As baixas temperaturas no interior do ambiente protegido foram decorrentes da elevada transparência do PEBD à radiação de onda longa, o que possibilitou um considerável resfriamento noturno no seu interior. Aliado a isso, como já comentando no item anterior, o saldo diário de radiação no interior do ambiente protegido era menor do que o registrado externamente (Anexos 10 e 11). Assim sendo, uma menor quantidade de energia calorífica era disponibilizada, à noite, no interior do ambiente protegido para os processos de aquecimento do ar e do solo, evapotranspiração, etc. Em conseqüência desse menor saldo de radiação, e do descenso das camadas de ar resfriadas, as temperaturas do ar dentro do ambiente protegido durante a madrugada e o início da manhã eram semelhantes às registradas externamente, às vezes menores. Temperaturas noturnas no interior do ambiente protegido inferiores às registradas externamente também foram encontradas por Herter \& Reisser Jr. (1987), Andriolo et al. (1989), Villele (1989), Mills et al. (1990) e Buriol et al. (1993b).

As diferenças de temperatura entre o interior e exterior do ambiente protegido, ao longo dos dois dias citados anteriormente, estão quantificadas na Figura 29. A maior diferença térmica aos $16 \mathrm{DAT}_{1}$ ocorreu às $11: 40 \mathrm{~h}$, quando a temperatura dentro do ambiente protegido superou a externa em $3,17^{\circ} \mathrm{C}$. A menor ocorreu às 7:40 quando a temperatura interna foi inferior em $0,94^{\circ} \mathrm{C}$ à externa.

Aos $22 \mathrm{DAT}_{2}$ a maior diferença ocorreu às $11: 20 \mathrm{~h}$, quando a temperatura no interior do ambiente protegido superou a externa em $3,77^{\circ} \mathrm{C}$, e a menor $\left(-1,96{ }^{\circ} \mathrm{C}\right)$ às 8:20 h. Observou-se, ainda, que as menores diferenças térmicas ocorreram no início da manhã, nos dois dias analisados, provavelmente porque na madrugada as temperaturas dentro do ambiente protegido já eram menores do que as registradas na estação meteorológica e, com o início da manhã, a radiação solar global foi maior na parte externa, possibilitando um aquecimento mais rápido fora do ambiente protegido. Entretanto, após o aumento da temperatura do ar no ambiente protegido, o ar interior deve ter se elevado convectivamente, porém contido pela cobertura plástica não pôde fazê-lo indefinidamente. Em conseqüência, acumulou-se nas partes superiores do 
ambiente protegido, aquecendo-o e contribuindo para a ocorrência de temperaturas superiores às registradas na estação meteorológica. Enfatiza-se que a reduzida velocidade do vento no interior do ambiente protegido deve acarretar uma baixíssima renovação das camadas de ar, o que deve também influir nas diferenças de temperatura entre o interior e o exterior do ambiente protegido.

(a)

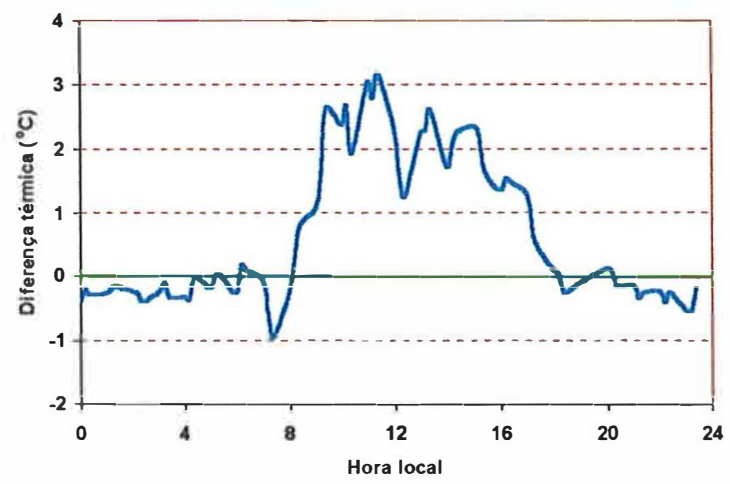

(b)

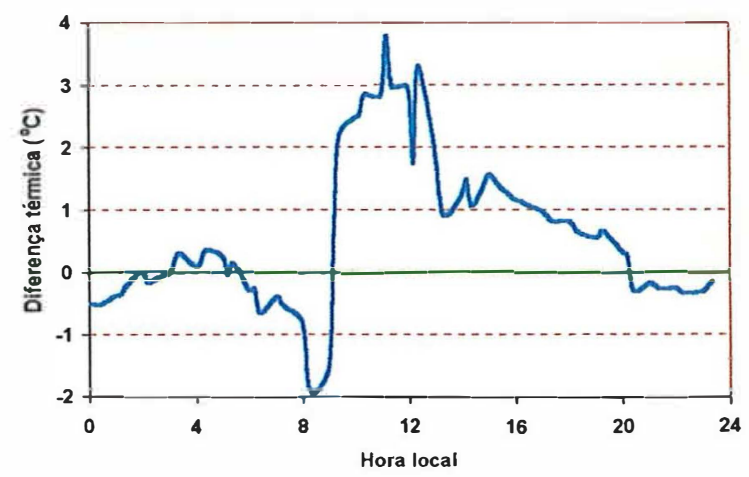

Figura 29 - Variação ao longo do dia da diferença entre as temperaturas do ar registradas no interior do ambiente protegido e na estação meteorológica, aos 16 DAT no primeiro cultivo (a) e aos 22 DAT no segundo cultivo (b), em Piracicaba, SP, no ano de 2000.

Na Figura 30 encontram-se as correlações entre as temperaturas médias diárias do ar obtidas dentro e fora do ambiente protegido, no primeiro (a) e no segundo (b) cultivos da alface. No primeiro cultivo, a temperatura média no interior do ambiente protegido foi superior à registrada externamente em $4,54 \%\left(r^{2}=0,971\right)$. No segundo, o acréscimo foi de $1,65 \%$, para um coeficiente de determinação de 0,984. Este menor acréscimo da temperatura média dentro do ambiente protegido, em comparação com externa, no segundo cultivo, deve ter ocorrido em função da estação, o inverno, quando se registra uma menor incidência média diária de radiação solar. Esta menor incidência deve ter contribuído para uma redução nos movimentos de ascensão convectiva, dentro 
do ambiente protegido. Assim sendo, ocorreu uma diminuição do aquecimento no interior do ambiente protegido, durante o período diurno, e por conseguinte, a diferença em relação à temperatura externa. Maiores temperaturas médias no interior do ambiente protegido também foram observadas por Montero et al. (1985), Farias et al. (1993a), Pezzopane (1994), Martins \& Gonzales (1995b) e Fernandes (1996).

(a)

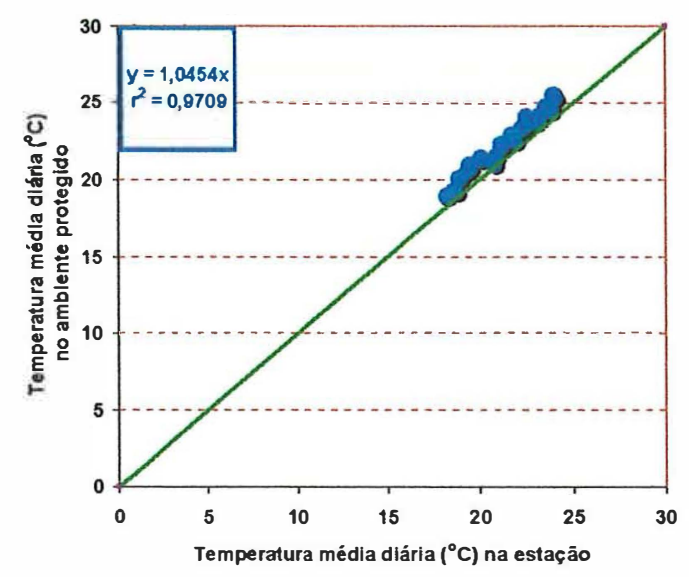

(b)



Figura 30 - Correlação entre a temperatura média diária do ar obtida no interior do ambiente protegido e na estação meteorológica, no primeiro (a) e segundo (b) cultivos da alface, em Piracicaba, SP, no ano de 2000.

A ascensão convectiva das camadas de ar aquecidas no interior do ambiente protegido e seu conseqüente acúmulo no período diurno na parte superior proporcionou no período vespertino, além de uma maior temperatura no seu interior, uma elevação da temperatura do ar com a altura, como pode ser visualizado na Figura 31 , aos $16 \operatorname{DAT}_{1}$ (a) e $13 \mathrm{DAT}_{2}(\mathrm{~b})$.

$\mathrm{O}$ maior acúmulo de calor nas partes mais altas do ambiente protegido deve contribuir para um acréscimo de temperatura com a altura, no seu interior, sendo mais bem caracterizado no período da tarde que, provavelmente, deve coincidir com o período de maior convecção. No início da noite, com o descenso das camadas de ar, este 
gradiente é minimizado chegando a ser imperceptível na madrugada, como pode ser visualizado na Figura 31. Um aumento da temperatura com a altura no interior do ambiente protegido, no período diurno, também foi observado por Buriol et al. (1997) e Furlan et al. (1999).

(a)



(b)

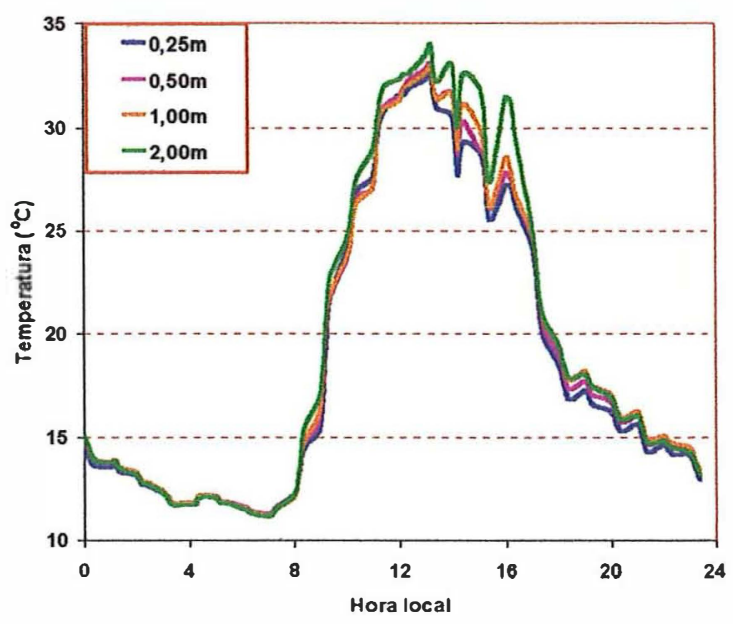

Figura 31 - Perfil vertical de temperatura do ar no interior do ambiente protegido, aos 16 DAT no primeiro cultivo (a) e aos 13 DAT no segundo cultivo (b), em Piracicaba, SP, no ano de 2000.

\subsubsection{Umidade relativa do ar}

Na Figura 32 observam-se as variações, aos $16 \mathrm{DAT}_{1}$ (a) e $22 \mathrm{DAT}_{2}$ (b), da umidade relativa do ar, medida dentro e fora do ambiente protegido. Em ambos os dias, registrou-se no período noturno, principalmente na madrugada, a ocorrência de maiores valores de umidade relativa no interior do ambiente protegido. Talvez, isso tenha ocorrido devido a uma maior quantidade de vapor d'água presente no ambiente protegido, em função da reduzida velocidade do vento no seu interior, e das menores temperaturas noturnas, em comparação com as registradas externamente. Enfatiza-se 
que, no início da manhã, em função das baixas temperaturas e velocidade do vento, a umidade relativa no interior da do ambiente protegido manteve-se até pelo menos às $8 \mathrm{~h}$ em $100 \%$, o que originava as maiores diferenças, quando comparada com a medida externa. Tanaka e Genta (1982), Montero et al. (1985), Bailey (1985), Levit \& Gaspar (1988) e Resi (1997) também encontraram valores de umidade relativa do ar superiores no interior do ambiente protegido durante a madrugada.

(a)

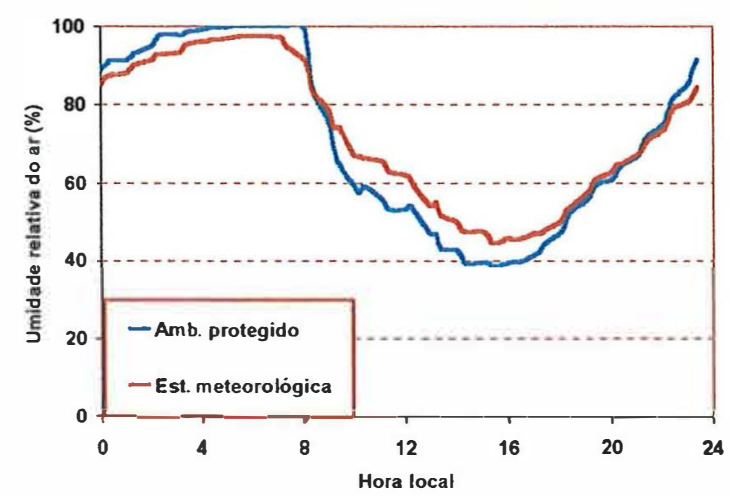

(b)

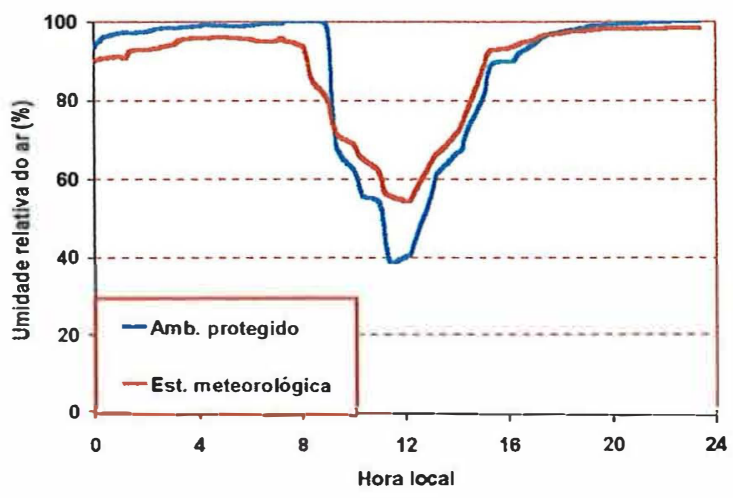

Figura 32 - Variação ao longo do dia da umidade relativa do ar medida no interior do ambiente protegido e na estação meteorológica, aos 16 DAT no primeiro cultivo (a) e aos 22 DAT no segundo cultivo (b), em Piracicaba, SP, no ano de 2000 .

As variações das diferenças entre a umidade relativa medida dentro e fora do ambiente protegido, aos $16 \mathrm{DAT}_{1}$ e $22 \mathrm{DAT}_{2}$, encontram-se na Figura 33. Em ambos os dias as maiores diferenças ocorreram no início da manhã, sendo aos $16 \mathrm{DAT}_{1}$ de 8,59 pontos percentuais com registro às $8: 00 \mathrm{~h}$ e aos $22 \mathrm{DAT}_{2}$ de 18,45 pontos às 9:00 $\mathrm{h}$. Notou-se, ainda, que após as maiores diferenças, em função do aquecimento do ambiente protegido e conseqüentemente da elevação de sua temperatura, a umidade relativa diminuiu acentuadamente, e nos dois dias registraram-se, no período diurno, valores inferiores aos ocorridos externamente. Como a umidade relativa apresenta 
variação inversa à da temperatura do ar, e no interior do ambiente protegido se registraram diurnamente valores de temperatura superiores aos externos, a umidade relativa tendeu a apresentar, no referido período, valores inferiores aos externos. Resultados semelhantes obtiveram Bailey (1985), Prados, (1986), Farias et al. (1993a) e Resi (1997).

(a)



(b)

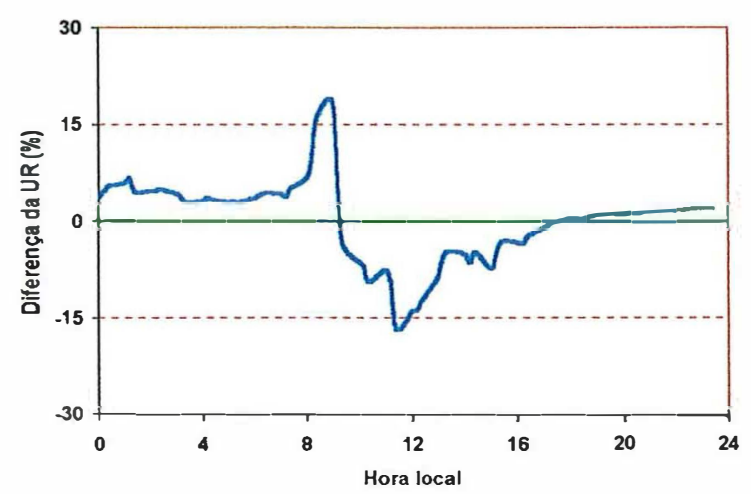

Figura 33 - Variação ao longo do dia da diferença entre a umidade relativa do ar registrada no interior do ambiente protegido e a registrada na estação meteorológica, aos 16 DAT no primeiro cultivo (a) e aos 22 DAT no segundo cultivo (b), em Piracicaba, SP, no ano de 2000.

Nos Anexos 14 e 15 encontram-se os valores médios diários da umidade relativa obtidos dentro e fora do ambiente protegido, no primeiro e no segundo cultivos, respectivamente. Notou-se que os valores obtidos dentro e fora do ambiente protegido foram semelhantes, fato que também pode ser visto através da Figura 34. No primeiro cultivo a umidade relativa média interna correspondeu a aproximadamente $99,5 \%$ da média externa $\left(r^{2}=0,919\right)$, ao passo que no segundo esse percentual foi de $100,3 \%\left(r^{2}\right.$ $=0,963)$.

As médias diárias foram bem próximas porque à noite a umidade relativa interna apresentava valores superiores aos registrados externamente, e durante a maior 
parte do período diurno a situação se invertia e, assim sendo, havia uma compensação entre os dois períodos citados. Resultados obtidos por Martinez Garcia et al. (1978), Montero et al. (1985) e Farias et al. (1993a) também apresentaram proximidade entre as umidade relativas médias externas e internas.

(a)

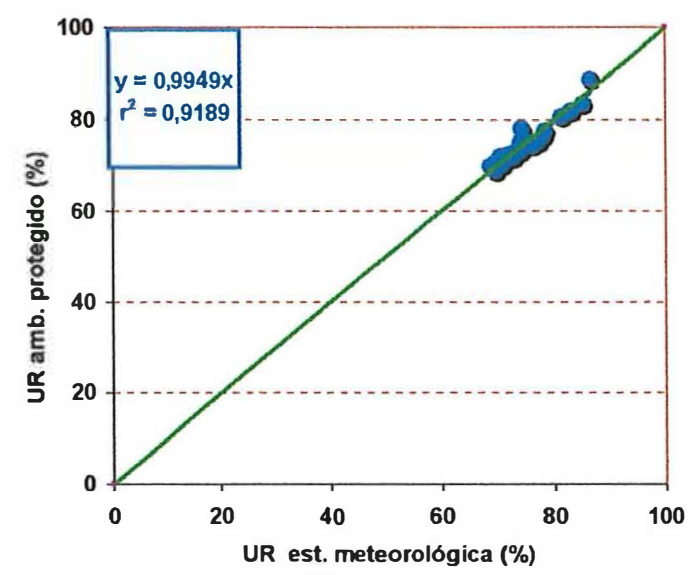

(b)

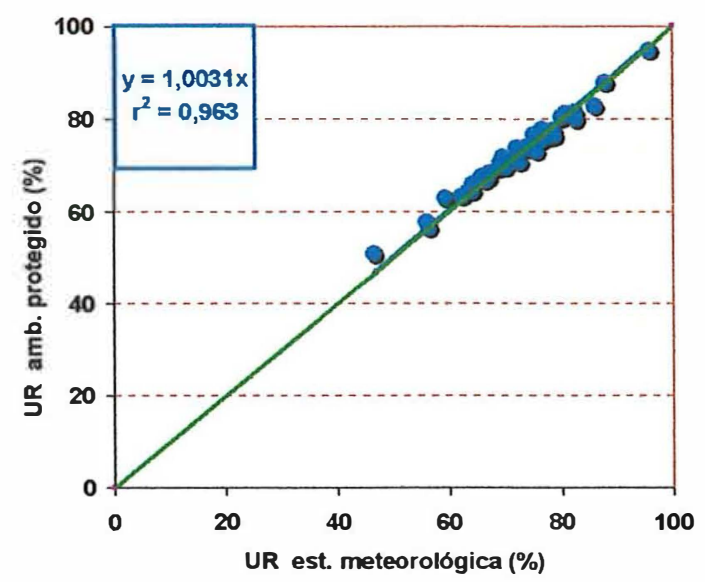

Figura 34 - Correlação entre a umidade relativa média diária do ar medida no interior do ambiente protegido e na estação meteorológica, no primeiro (a) e no segundo (b) cultivos da alface, em Piracicaba, SP, no ano de 2000.

\subsubsection{Velocidade do vento}

Tentou-se inicialmente medir a velocidade do vento no interior do ambiente protegido com o uso de um anemômetro de canecas, descrito no item Material e Métodos. Como observou-se que comumente o sensor não era movimentado no interior do ambiente protegido, e este freqüentemente registrava $0,2 \mathrm{~m} . \mathrm{s}^{-1}$, como pode ser visualizado na Figura 35, optou-se por descartar esses dados e estimar a velocidade do vento como $5 \%$ da obtida externamente, conforme conclusão de Prados (1986). Ressalta-se que às vezes o referido anemômetro girava em pequenos intervalos de tempo 
mas, como os dados gerados eram médias para cada 20 minutos, o resultado final acabava sendo de aproximadamente $0,2 \mathrm{~m} \cdot \mathrm{s}^{-1}$.

(a)

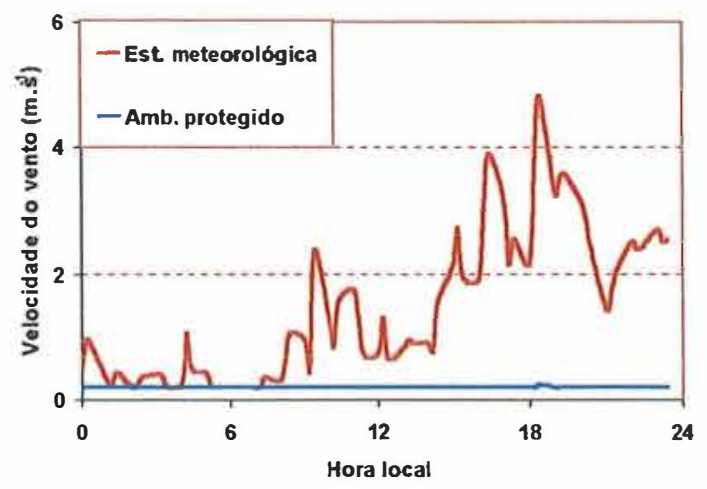

(b)

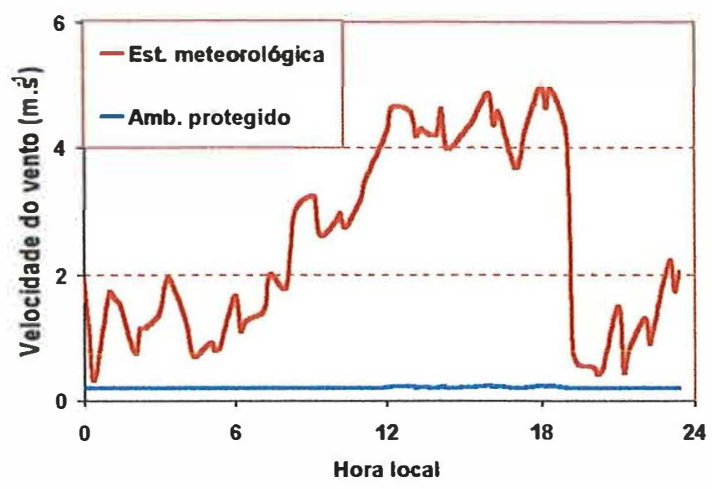

Figura 35 - Variação ao longo do dia da velocidade do vento medida no interior do ambiente protegido e na estação meteorológica, aos 67 (a) e 68 (b) dias Julianos, em Piracicaba, SP, no ano de 2000.

Na Figura 36 são apresentadas as variações da velocidade do vento dentro e fora do ambiente protegido, aos $16 \mathrm{DAT}_{1}$ (a) e $22 \mathrm{DAT}_{2}$ (b). Observou-se, através da estimativa da velocidade do vento no interior do ambiente protegido, em $5 \%$ da externa, que predominavam valores inferiores a $0,2 \mathrm{~m} \cdot \mathrm{s}^{-1} \mathrm{e}$, portanto, impossíveis de serem medidos com o anemômetro disponível. Externamente, aos $16 \mathrm{DAT}_{1}$ a velocidade do vento foi sempre superior a $0,2 \mathrm{~m} \cdot \mathrm{s}^{-1}$ atingindo $3,862 \mathrm{~m} \cdot \mathrm{s}^{-1}$ às 13:00 h. Aos $22 \mathrm{DAT}_{2}$ apresentou maior valor, $3,190 \mathrm{~m} \cdot \mathrm{s}^{-1}$, às 4:00 h.

Nos Anexos 16 e 17 encontram-se os valores médios diários e diurnos da velocidade do vento, obtidos no interior do ambiente protegido e na estação meteorológica, no primeiro e no segundo cultivos, respectivamente. A velocidade média do vento, externa, ao longo do primeiro cultivo foi de $1,195 \mathrm{~m} \cdot \mathrm{s}^{-1}$, enquanto no segundo cultivo foi de $1,523 \mathrm{~m} \cdot \mathrm{s}^{-1}$. Quando analisou-se somente o período diurno, as médias elevaram-se para 1,324 e $1,725 \mathrm{~m} . \mathrm{s}^{-1}$, respectivamente, para o primeiro e o 
segundo cultivos. Por conseguinte, observou-se velocidade média do vento, diária e diurna, no segundo cultivo superior à do primeiro.

(a)

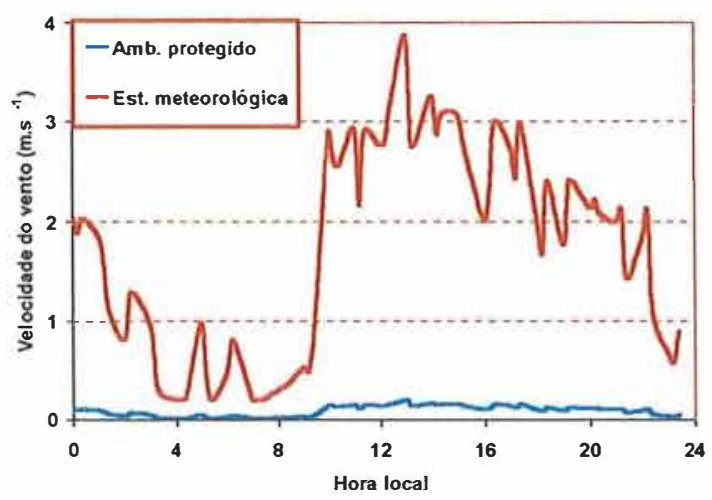

(b)

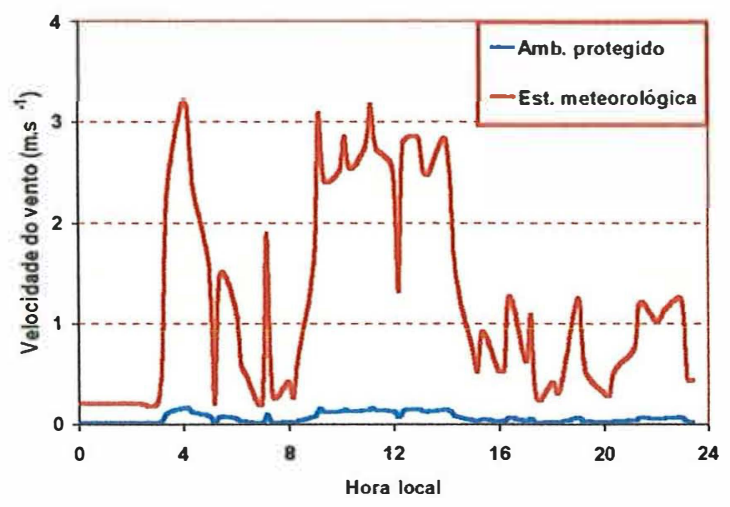

Figura 36 - Variação ao longo do dia da velocidade do vento medida, na estação meteorológica, e estimada, no ambiente protegido, aos 16 DAT no primeiro cultivo (a) e aos 22 DAT no segundo cultivo (b), em Piracicaba, SP, no ano de 2000.

\subsubsection{Evapotranspiração de referência}

Observam-se na Figura 37 as variações ao longo do dia da evapotranspiração de referência, estimada pelo método de Penman-Monteith, com os dados obtidos na estação meteorológica e no interior do ambiente protegido, aos 16 $\mathrm{DAT}_{1}$ (a) e $22 \mathrm{DAT}_{2}$ (b). Nota-se que a evapotranspiração de referência estimada com dados externos, ao longo de ambos os dias, foi superior à estimada com dados internos.

Observou-se no primeiro e no segundo cultivos maiores valores diários da evapotranspiração de referência estimada com dados obtidos na estação meteorológica (Figura 38 e Anexos 18 e 19). A evapotranspiração estimada com dados internos representou $70,32\left(r^{2}=0,744\right)$ e $60,14 \%\left(r^{2}=0,719\right)$ do total externo, no primeiro e no segundo cultivos, respectivamente. 
(a)

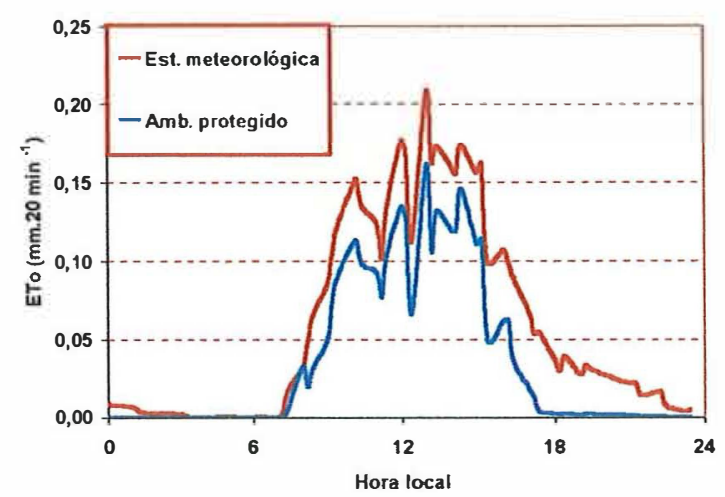

(b)

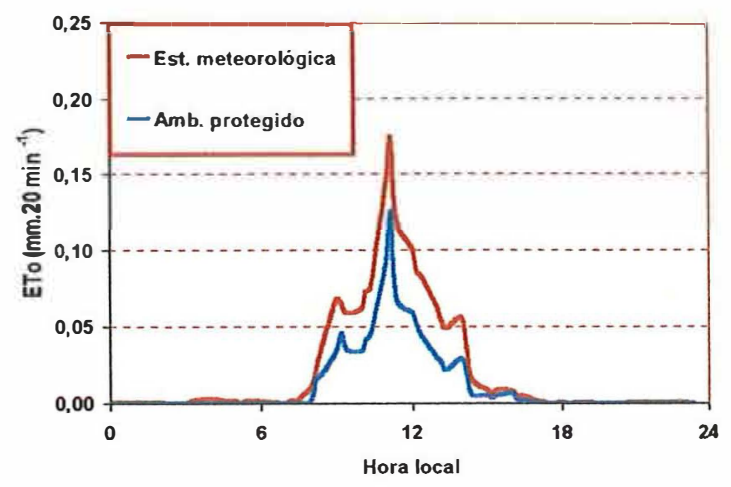

Figura 37 - Variação ao longo do dia da evapotranspiração de referência (ETo) estimada, com a equação de Penman-Monteith, utilizando dados observados na estação meteorológica e no interior do ambiente protegido, aos 16 DAT no primeiro cultivo (a) e aos 22 DAT no segundo cultivo (b), em Piracicaba, SP, no ano de 2000.

(a)

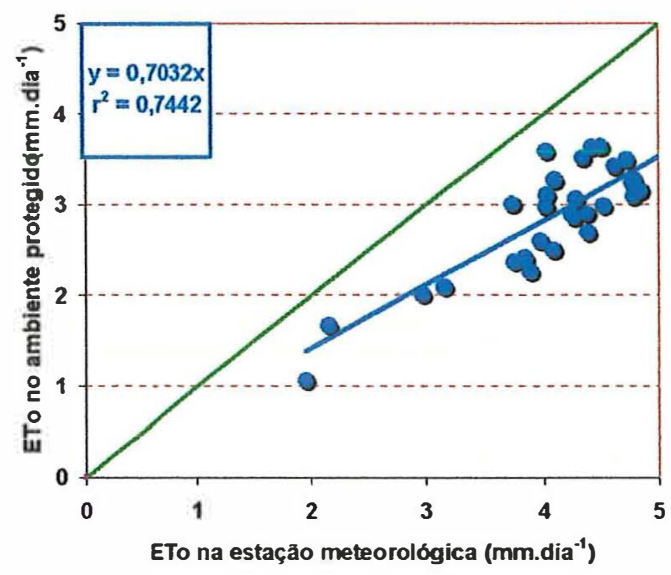

(b)

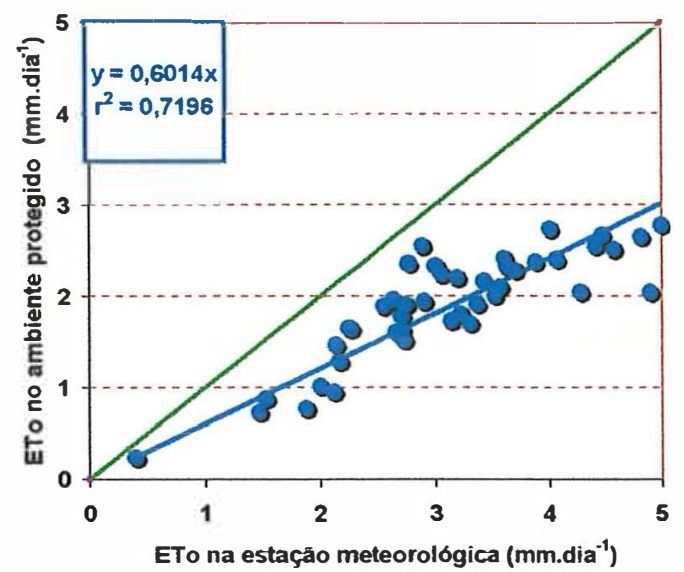

Figura 38 - Correlação entre a evapotranspiração de referência (ETo) estimada, com a equação de Penman-Monteith, utilizando dados observados no interior do ambiente protegido e na estação meteorológica, no primeiro (a) e no segundo (b) cultivos, em Piracicaba, SP, no ano de 2000. 
Valores de evapotranspiração de referência, estimados para o interior do ambiente protegido, inferiores aos registrados externamente, também foram observados por Montero et al. (1985), Prados (1986), Rosemberg et al. (1989), Boulard \& Jemaa (1991), Martins (1992), Farias et al. (1994), Martins \& Gonzalez (1995), e Faccioli (1998).

\subsection{Balanço de energia}

As variações ao longo do período diurno da razão de Bowen, aos $16 \mathrm{DAT}_{1}$ e $22 \mathrm{DAT}_{2}$, encontram-se na Figura 39, (a) e (b), respectivamente. Os valores da razão de Bowen encontram-se também, além dos gradientes de temperatura do ar e pressão parcial do vapor, nos Anexos 20 e 21. Ressalta-se que os dois dias analisados apresentaram balanços de energia que caracterizaram os dois cultivos.

(a)

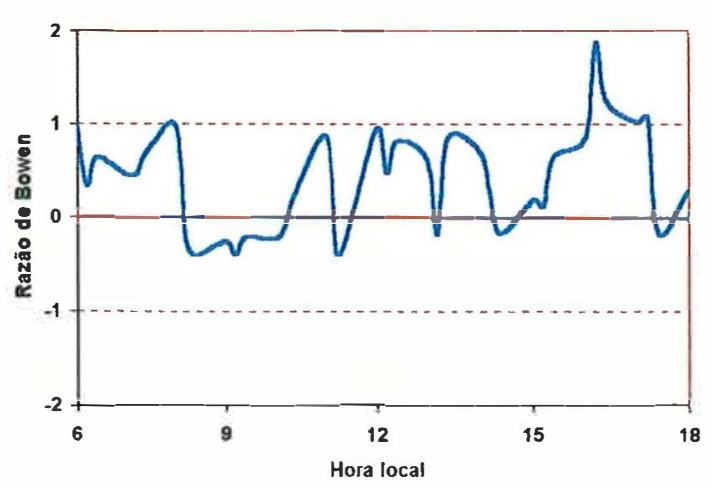

(b)

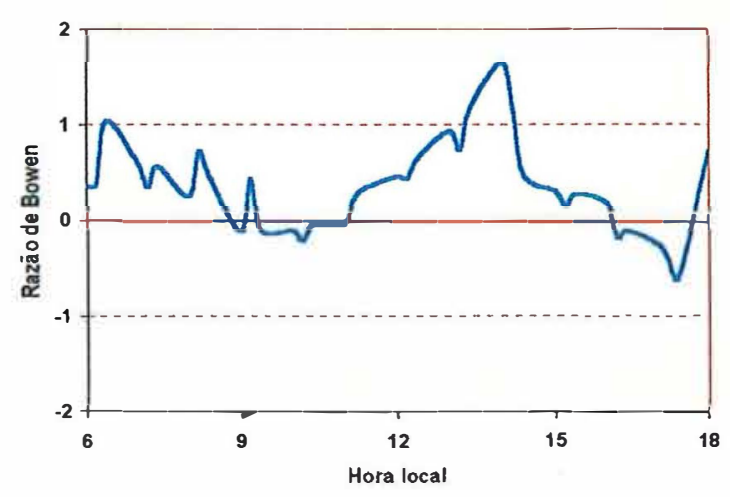

Figura 39 - Variação no período diurno da razão de Bowen, no interior do ambiente protegido cultivado com alface, aos 16 DAT no primeiro cultivo (a) e aos 22 DAT no segundo cultivo (b), em Piracicaba, SP, no ano de 2000.

Observou-se aos $16 \mathrm{DAT}_{1}$ e $22 \mathrm{DAT}_{2}$ que a razão de Bowen apresentou desde valores próximos a $-0,7$ até valores próximos a 2,0 , sendo o valor médio diurno de 
0,56 e 0,47 , respectivamente, aos $16 \mathrm{DAT}_{1}$ e $22 \mathrm{DAT}_{2}$. Esses valores foram superiores aos registrados, em ambiente externo sob condições ideais de umidade do solo, por Gutiérrez \& Meinzer (1994), 0,36 em café, por Cargenel et al. (1996), valores próximos a zero em feijão, e Reschke et al. (1997), 0,21 em floresta e 0,30 em pastagem.

Os gradientes térmicos representavam, em concordância com o programa instalado no sistema razão de Bowen, a diferença entre o valor observado a 0,25 m e o observado a 1,25 m. Portanto, valores negativos do gradiente térmico representavam aumento da temperatura com a altura e, do mesmo modo, valores negativos do gradiente de pressão parcial do vapor mostravam aumento da referida pressão com a altura.

Os valores dos gradientes térmicos e de pressão parcial do vapor foram, predominantemente, negativos, principalmente à tarde, como pode ser visualizado nos Anexos 20 e 21. O gradiente térmico variou assim devido ao bloqueio dos movimentos convectivos pelo plástico, o que fez com que no interior do ambiente protegido, principalmente no período vespertino, a temperatura aumentasse com a altura de observação. A diminuição desses movimentos convectivos deve ter também impedido uma maior redistribuição do vapor d'água e, em conseqüência, ocorreu sua retenção nas camadas mais altas do ambiente protegido, o que possibilitou gradientes de pressão parcial do vapor também negativos. Como os dois gradientes eram negativos e, portanto, variaram de maneira inversa ao que comumente se registra em ambiente externo no período diurno, e em condições de solo úmido (a temperatura e a pressão de vapor diminuem com o aumento da altura de observação), conforme verificado por Cargenel et al. (1996), Cunha et al. (1996), Oliveira et al. (1997) e Perez et al. (1999), a razão de Bowen apresentava, em muitos momentos, valores positivos no período diurno. Entretanto, o meio parece ser desfavorável ao método, pois o próprio Bowen (1926) quando o idealizou, para condições externas, baseou-se na redução de temperatura e pressão parcial do vapor com a altura. Enfatiza-se, ainda, que a diminuição dos movimentos convectivos deve proporcionar reduções nas dimensões dos gradientes, em comparação com o ambiente externo. Tal redução deve ser um complicador para o SRB, pois, segundo Perez et al. (1999), este produz estimativas pouco consistentes com pequenos valores de gradientes de pressão parcial do vapor. 
Na Figura 40 estão plotadas as variações diurnas dos fluxos de energia aos $16 \operatorname{DAT}_{1}$ (a) e $22 \operatorname{DAT}_{2}$ (b). Por ela nota-se que o saldo de radiação (Rn) foi consideravelmente maior aos $16 \mathrm{DAT}_{1}$, possibilitando, neste dia, fluxos de calor, latente e sensivel, mais intensos. Os maiores valores médios em 20 minutos de $\mathrm{Rn}$ foram 424,82 W.m. $\mathrm{m}^{-2}$ aos $16 \mathrm{DAT}_{1}$, às 13:00 h, e 314,80 W.m. ${ }^{-2}$ aos $22 \mathrm{DAT}_{2}$, às 11:20 h. A partir das 14:00 h, aos $22 \mathrm{DAT}_{2}$, os fluxos de calor foram sensivelmente reduzidos em virtude da redução drástica neste período do saldo de radiação, ao passo que aos $16 \mathrm{DAT}_{1}$ somente após às $16: 40 \mathrm{~h}$ o saldo de radiação foi reduzido a valores inferiores a $100 \mathrm{~W} \cdot \mathrm{m}^{-2}$.

(a)

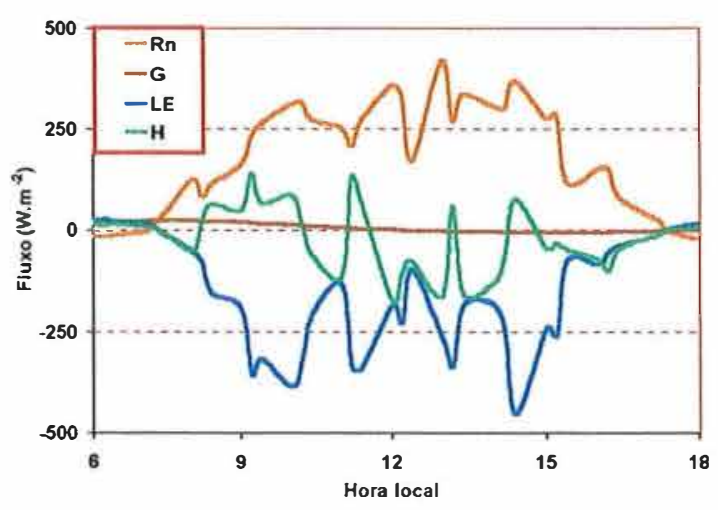

(b)

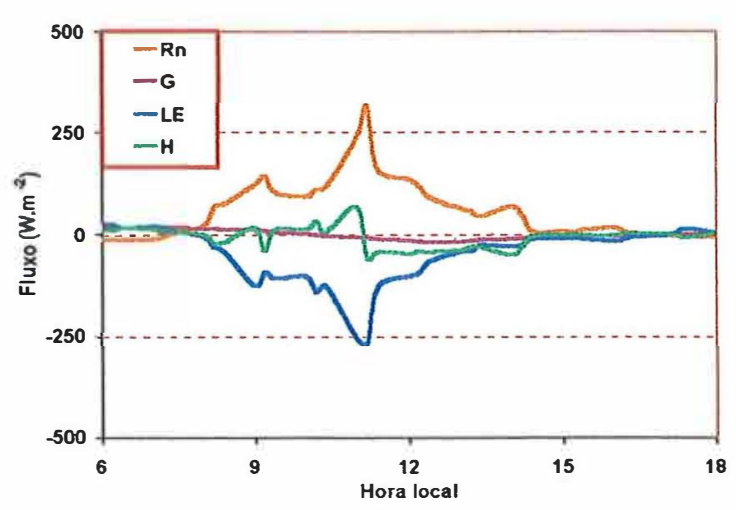

Figura 40 - Variação no período diurno dos fluxos de energia, no interior do ambiente protegido cultivado com alface, aos 16 DAT no primeiro cultivo (a) e aos 22 DAT no segundo cultivo (b), em Piracicaba, SP, no ano de 2000.

O fluxo de calor no solo (G) apresentou valores baixos ao longo do período diurno, em ambos os dias, predominando valores positivos no início do período diurno, caracterizando o aquecimento da superfície pelas camadas do solo abaixo desta. Em oposição, no período da tarde predominaram valores negativos, caracterizando o aquecimento das camadas abaixo da superfície do solo pela superfície, provavelmente devido a uma maior temperatura na superfície em função do seu maior aquecimento 
pela incidência direta de radiação solar. Nessas condições ocorreu um fluxo de calor sensível, por condução da superficie para as camadas do solo abaixo desta.

O fluxo de calor latente de evapotranspiração (LE) apresentou, principalmente aos $16 \mathrm{DAT}_{1}$, em alguns momentos, valores superiores aos do saldo de radiação em virtude do fluxo de calor sensivel do ar, que apresentou valores positivos, contribuindo na ocorrência da evapotranspiração. Tais acréscimos, originários da elevação da temperatura com a altura, contribuíram para o aumento do fluxo de calor latente de evapotranspiração. O maior fluxo de calor latente de evapotranspiração, aos $16 \mathrm{DAT}_{1}$, foi registrado às $14: 40 \mathrm{~h}$ sendo de $454,65 \mathrm{~W} . \mathrm{m}^{-2}$. Nesse momento, o fluxo de calor no solo era de $-5,81 \mathrm{~W} \cdot \mathrm{m}^{-2}$, o saldo de radiação $372,94 \mathrm{~W} \cdot \mathrm{m}^{-2}$, portanto inferior ao fluxo de calor latente de evapotranspiração, que só registrou o valor referido anteriormente devido à contribuição de $87,52 \mathrm{~W} \cdot \mathrm{m}^{-2}$ do fluxo de calor sensivel do ar.

Aos $22 \mathrm{DAT}_{2}$ o maior fluxo de calor latente de evapotranspiração foi registrado às $11: 20 \mathrm{~h}$ sendo de $264,18 \mathrm{~W} \cdot \mathrm{m}^{-2}$. Nesse momento, os fluxos de calor sensivel no ar e no solo também foram negativos, sendo de $59,26 \mathrm{~W} \cdot \mathrm{m}^{-2}$ e de $8,64 \mathrm{~W} \cdot \mathrm{m}^{-2}$, respectivamente.

Em síntese, a partição do saldo de radiação, aos $16 \mathrm{DAT}_{1}$, ficou assim constituída: 62,6 \% para o fluxo de calor latente de evapotranspiração (LE), 34,7 \% para o fluxo de calor sensível no ar $(\mathrm{H})$ e 3,3 \% para o fluxo de calor sensível no solo (G). Aos $22 \mathrm{DAT}_{2}$ a referida partição ficou assim quantificada: 67,2 \% para LE, 31,5\% para $\mathrm{H}$ e 1,3\% para G. Os percentuais obtidos, nos dois dias, para o fluxo de calor latente de evapotranspiração foram inferiores aos obtidos externamente, sob condições ideais de umidade do solo, por Fontana et al. (1991) com soja (95\%), por Cunha et al. (1996) com milho (80\%) e por Oliveira et al. (1997) com amendoim (93,2\%). Esses menores percentuais, obtidos para LE, podem ser resultados da dificuldade do SRB em medir gradientes de pressão parcial do vapor no interior do ambiente protegido, o que implicaria na superestimativa dos valores da razão de Bowen, e subestimativas do fluxo de calor latente de evapotranspiração. Ressalta-se que os elevados percentuais obtidos por Fontana et al. (1991), com soja, e Oliveira et al. (1997), com amendoim, também 
foram frutos de contribuição advectiva, contribuição esta de menor magnitude no interior do ambiente protegido.

\subsection{Evapotranspiração da cultura}

Os valores da evapotranspiração da cultura, medidos pelo lisímetro de pesagem e estimados pelo sistema razão de Bowen, estão apresentados na Figura 41, para o primeiro (a) e o segundo (b) cultivos. Os valores diários da evapotranspiração da cultura podem também ser visualizados nos Anexos 22 e 23. Ressalta-se que nos dois períodos analisados as cortinas foram mantidas abertas para possibilitar maior ventilação e renovação das camadas de ar no interior do ambiente protegido.

No primeiro cultivo a evapotranspiração da alface, do transplantio ao início da colheita, medida pelo lisímetro de pesagem, foi de 102,98 mm, com média diária de 3,32 mm. Enfatiza-se que o primeiro cultivo perdurou por 31 dias. O sistema razão de Bowen subestimou a evapotranspiração em relação ao lisímetro, sendo de $78,18 \mathrm{~mm}$, com média diária de $2,52 \mathrm{~mm}$. A evaporanspiração estimada pelo SRB para o primeiro cultivo correspondeu a $75,9 \%$ da medida pelo lisímetro de pesagem.

No segundo cultivo, com duração de 43 dias, a evapotranspiração média diária medida pelo lisímetro de pesagem foi de $2,16 \mathrm{~mm}$, ao passo que a média diária estimada pelo sistema razão de Bowen foi de $1,43 \mathrm{~mm}$. A evapotranspiração total no segundo cultivo foi de $92,93 \mathrm{~mm}$, obtida com o lisímetro, e de $61,62 \mathrm{~mm}$ com o sistema razão de Bowen. A evapotranspiração total estimada pelo SRB representou, neste cultivo, $66,3 \%$ da medida pelo lisímetro de pesagem.

Observou-se, nos dois cultivos, que o sistema razão de Bowen subestimou a evapotranspiração da cultura. A subestimativa da evapotranspiração da cultura pode ser originária de superestimativa, no interior do ambiente protegido, da razão de Bowen. Valores positivos e elevados da razão de Bowen implicariam a estimativa de maior fluxo de calor sensível do ar, em detrimento do fluxo de calor latente de evapotranspiração. Essa superestimativa da razão de Bowen pode ser decorrente da dificuldade em se medir gradientes de pressão parcial do vapor no interior do ambiente protegido. Pode-se 
observar nos Anexos 20 e 21 que, comumente, os gradientes de pressão parcial do vapor não ultrapassavam $0,03 \mathrm{kPa}$.

(a)

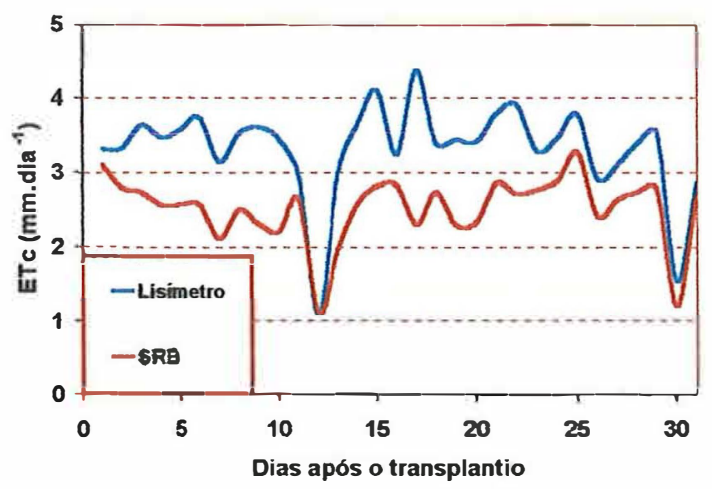

(b)

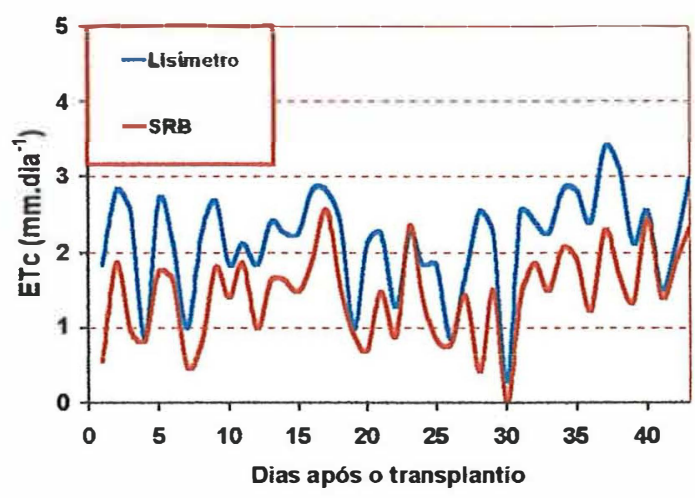

Figura 41 - Variação da evapotranspiração da cultura (ETc) medida no lisímetro de pesagem e estimada no sistema razão de Bowen (SRB), no primeiro (a) e no segundo (b) cultivos da alface, em Piracicaba, SP, no ano de 2000.

No interior do ambiente protegido, tanto os gradientes de pressão parcial do vapor como os de temperatura devem ser inferiores aos registrados no ambiente externo, devido à redução dos movimentos convectivos e da velocidade do vento. Entretanto, valores elevados da razão de Bowen implicam a ocorrência de uma maior redução nos gradientes de pressão parcial do vapor, em comparação com os gradientes térmicos. Em conseqüência, pode-se afirmar que a redução dos movimentos convectivos e da velocidade do vento, no interior do ambiente protegido, afetam de forma mais acentuada os gradientes de pressão do vapor, em comparação com o gradiente térmico, resultando em subestimativa da evapotranspiração da cultura. Ressalta-se que a superestimativa de valores negativos da razão de Bowen implicariam, no período diurno, fluxos de calor latente mais intensos, uma vez que seria adicionada ao saldo de radiação a energia proveniente do fluxo de calor sensível. Entretanto, valores negativos de razão de Bowen, no período diurno, foram menos freqüentes. 
Na Figura 42 encontram-se as correlações entre os valores de ETc obtidos no lisímetro de pesagem e no sistema razão de Bowen, quando todos os dias foram considerados, no primeiro (a) e no segundo (b) cultivos da alface. No primeiro cultivo a evapotranspiração da cultura estimada pelo sistema razão de Bowen representou 75,11 $\%$ da medida pelo lisímetro de pesagem. Entretanto, o valor do coeficiente de determinação foi de 0,433 , mostrando baixa precisão entre os dados. Do mesmo modo, o coeficiente de Wilmott foi de 0,622 , indicando não haver uma boa exatidão entre os dados medidos no lisímetro de pesagem, e estimados, no SRB.

(a)

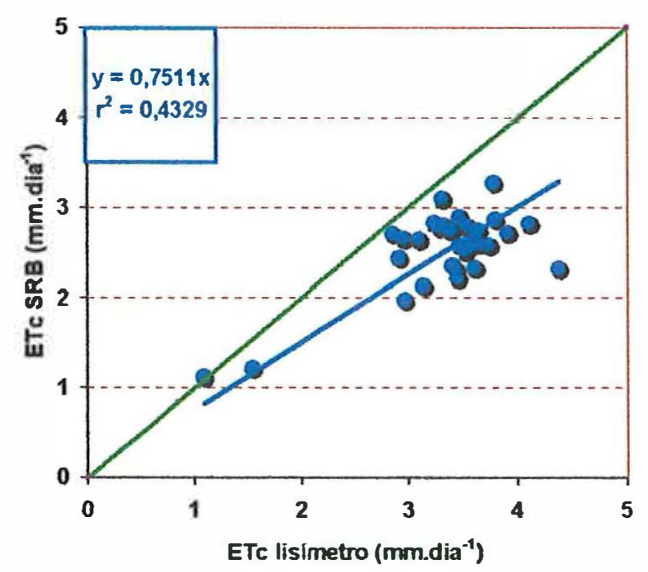

(b)

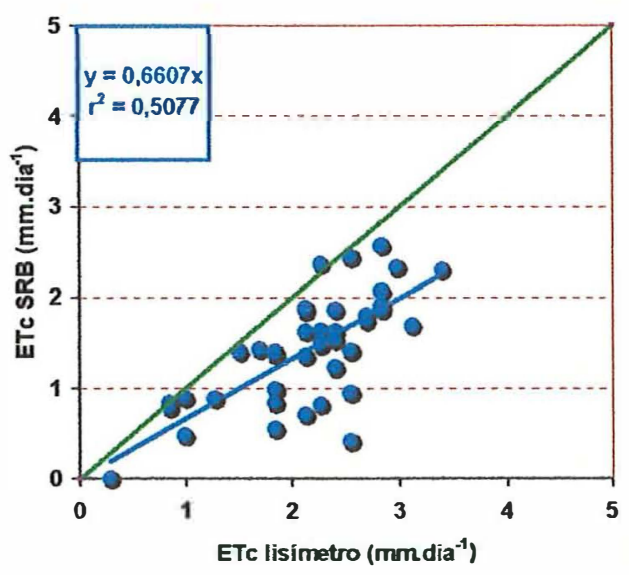

Figura 42 - Correlação entre a evapotranspiração da cultura (ETc) medida no lisímetro de pesagem e estimada no sistema razão de Bowen (SRB), no primeiro (a) e no segundo (b) cultivos da alface, em Piracicaba, SP, no ano de 2000.

No segundo cultivo ocorreu variação semelhante, sendo que a ETc estimada a partir da razão de Bowen representou 66,07 \% da ETc medida no lisímetro de pesagem, porém também com baixo $r^{2}$, 0,508. O coeficiente de Wilmott foi bem superior ao registrado no segundo cultivo, 0,789. Esse valor maior do índice de Wilmott, no segundo cultivo, deveu-se aos menores valores de evapotranspiração da 
cultura ao longo do cultivo que, matematicamente, contribuiu para minimizar as diferenças entre os valores medidos e estimados.

A baixa correlação obtida entre os dados medidos pelo lisímetro de pesagem e estimados pelo SRB, quando todos os dias foram considerados, diferiu dos resultados encontrados, a céu aberto, por Tanner et al. (1987), Nie et. al. (1992), Malek (1993), Azevedo (1999) e Silva (2000). Entretanto, em ambiente protegido há uma baixa renovação das camadas de ar, o que implica condições bem distintas das que ocorrem externamente.

Analisou-se, também, a resposta do sistema razão de Bowen nos dias com velocidade média diurna do vento, externa, superior e inferior a $1,5 \mathrm{~m} \cdot \mathrm{s}^{-1}$. Referida análise fundamentou-se na hipótese de que em dias com maiores velocidades externas do vento poderia ocorrer, no interior do ambiente protegido, uma maior renovação do ar, possibilitando a ocorrência de maiores gradientes de pressão parcial do vapor e, em conseqüência, menores valores da razão de Bowen. Nessas condições, alimentava-se que a evapotranspiração da cultura estimada pelo sistema razão de Bowen pudesse se aproximar mais dos valores medidos no lisímetro de pesagem e aumentar os coeficientes de determinação e de Wilmott. Ressalta-se que a velocidade média de $1,5 \mathrm{~m} . \mathrm{s}^{-1}$ foi adotada como divisora da situação, pois no primeiro cultivo, em que ocorreram as menores velocidades médias do vento, apenas dois dias apresentaram médias superiores a 2,0 m.s $\mathrm{s}^{-1}$, ao passo que 11 apresentaram valores superiores a $1,5 \mathrm{~m} \cdot \mathrm{s}^{-1}$.

Na Figura 43 encontram-se os resultados das correlações entre os dados medidos e estimados, para dias com velocidade média do vento, no período diurno, superior a $1,5 \mathrm{~m} \cdot \mathrm{s}^{-1}$, para o primeiro (a) e o segundo (b) cultivos. Observam-se em ambos os cultivos maiores valores dos coeficientes de correlação e de Wilmott. No primeiro cultivo, o valor de $\mathrm{r}^{2}$ aumentou de 0,432 , quando todos os dias foram considerados, para 0,732. O índice de Wilmott aumentou de 0,622 para 0,681. No segundo cultivo o coeficiente de determinação aumentou de 0,508 para 0,663 e o de Wilmott de 0,789 para 0,799. Entretanto, nota-se que apesar de uma maior exatidão entre os valores medidos e estimados, o SRB continuou subestimando a evapotranspiração da cultura nos dias analisados. 
(a)

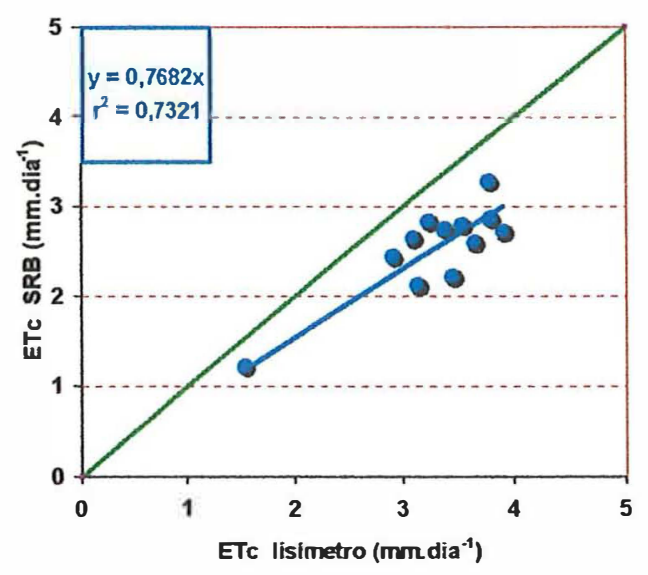

(b)

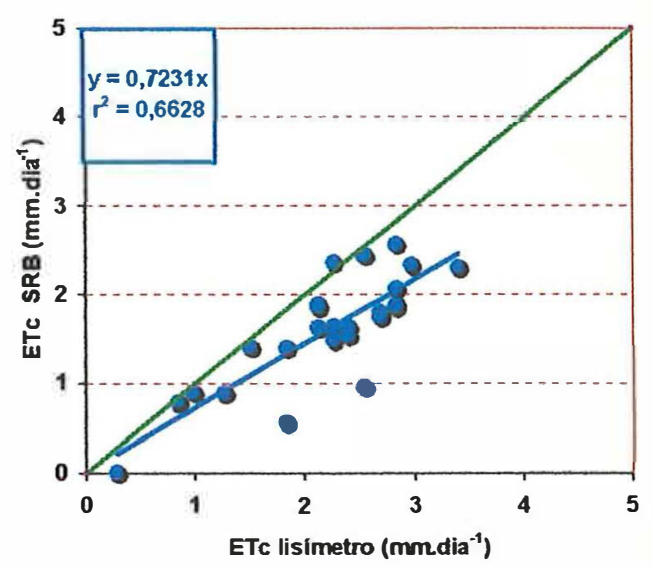

Figura 43 - Correlação entre a evapotranspiração da cultura medida no lisímetro de pesagem e estimada no sistema razão de Bowen (SRB), em dias com velocidade média diurna do vento superior a $1,5 \mathrm{~m} . \mathrm{s}^{-1}$, no primeiro (a) e no segundo (b) cultivos, em Piracicaba, SP, no ano de 2000.

Quando analisaram-se somente os dias com velocidade média do vento, diurna, inferiores a $1,5 \mathrm{~m} \cdot \mathrm{s}^{-1}$, os valores de $\mathrm{r}^{2}$ foram reduzidos significativamente (Figura 44). Nessa condição, os coeficientes de determinação foram de 0,186 e 0,192, respectivamente, para o primeiro e o segundo cultivos. O índice de Wilmott apresentou os seguintes valores: 0,669 e 0,490, para os respectivos cultivos citados anteriormente. Em ambos os cultivos, o desempenho do sistema razão de Bowen nos dias com velocidade média diurna do vento menores que $1,5 \mathrm{~m} . \mathrm{s}^{-1}$ foi muito inferior ao registrado nos dias com velocidades superiores a $1,5 \mathrm{~m} . \mathrm{s}^{-1}$. Nota-se, ainda, que além de uma menor exatidão entre os valores medidos e estimados, o SRB continuou subestimando a evapotranspiração da cultura nos dias analisados.

Os resultados obtidos nos dias com velocidade do vento média, diurna, superiores a 1,5 m. $\mathrm{s}^{-1}$ mostraram um melhor desempenho do sistema razão de Bowen nessas condições, para o uso em ambiente protegido. Entretanto, mesmo nesses dias o SRB subestimou a evapotranspiração da cultura medida no lisímetro de pesagem, 
mostrando que o método da razão de Bowen pode requerer ajustes para um adequado uso no interior de ambiente protegido, ao contrário do que foi observado a céu aberto por Tanner (1960), Vila Nova (1973), Dunin et al. (1989), Kroon (1989), Mastrorilli et al. (1989), Peterscmitt \& Katerji (1989), Fontana et al. (1991), Maki (1991), Moura \& Martins (1992), Herbst et al. (1996), Bergamaschi et al. (1998), e Steduto \& Hsiao (1998).

(a)

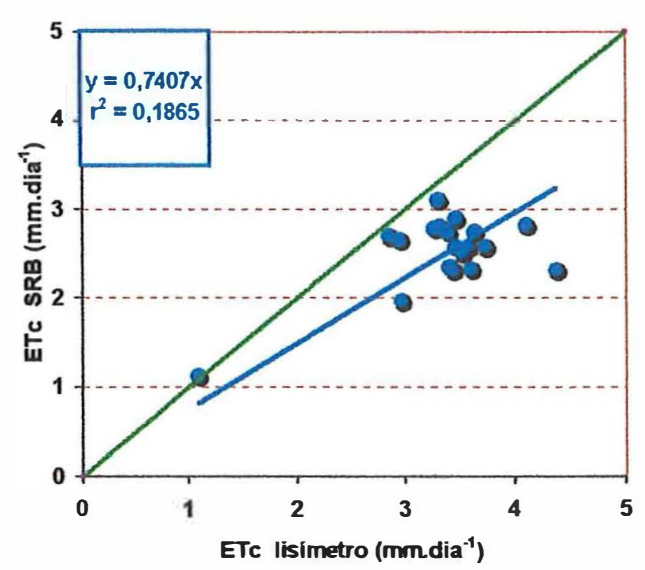

(b)

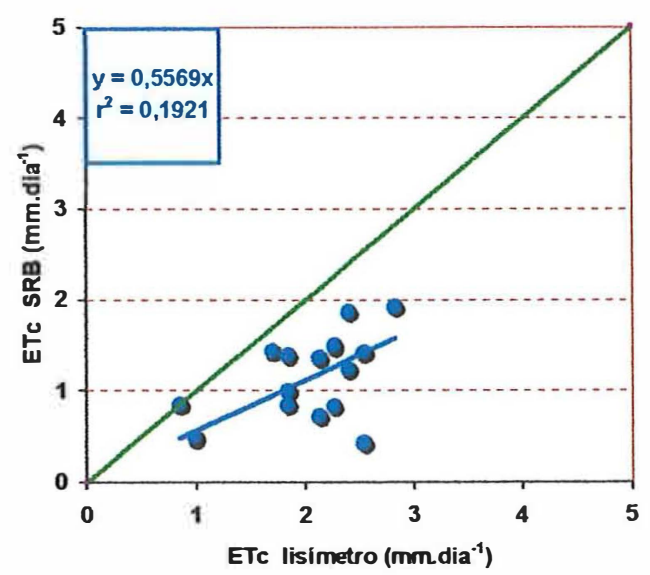

Figura 44 - Correlação entre a evapotranspiração da cultura medida no lisímetro de pesagem e a estimada no sistema razão de Bowen, em dias com velocidade média diurna do vento inferior a $1,5 \mathrm{~m} \cdot \mathrm{s}^{-1}$, no primeiro (a) e no segundo (b) cultivos da alface, em Piracicaba, SP, no ano de 2000.

Nos dias com maiores velocidades do vento ocorreram, na maioria das vezes, no interior do ambiente protegido, maiores gradientes de pressão parcial de vento (Figura 45), em comparação com os registrados nos dias com baixa velocidade vento (Figura 46). Entretanto, nos dias com maiores velocidades do vento, o SRB continuou a subestimar a evapotranspiração da cultura, talvez devido aos baixos gradientes de pressão de vapor, mesmo nessas condições. Enfatiza-se que os baixos gradientes de pressão do vapor além de implicarem valores elevados da razão de Bowen, diminuem a 
confiabilidade dos valores estimados pelo SRB, conforme comentário feito por Perez et al. (1999).

(a)

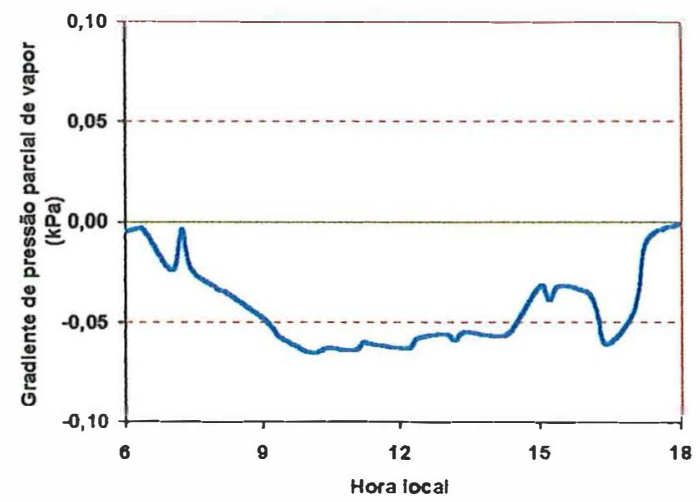

(b)

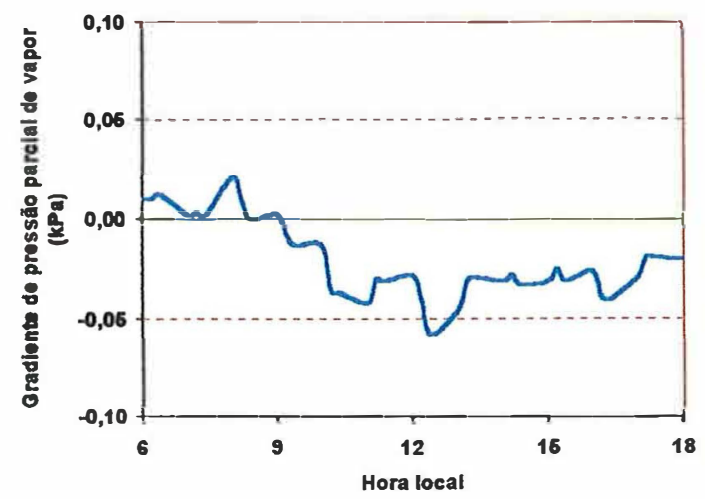

Figura 45 - Variação no período diurno do gradiente de pressão parcial do vapor aos 26 dias após transplantio, no primeiro cultivo (a) e aos 23 dias após transplantio, no segundo cultivo da alface (b), em Piracicaba, SP, no ano de 2000.

(a)

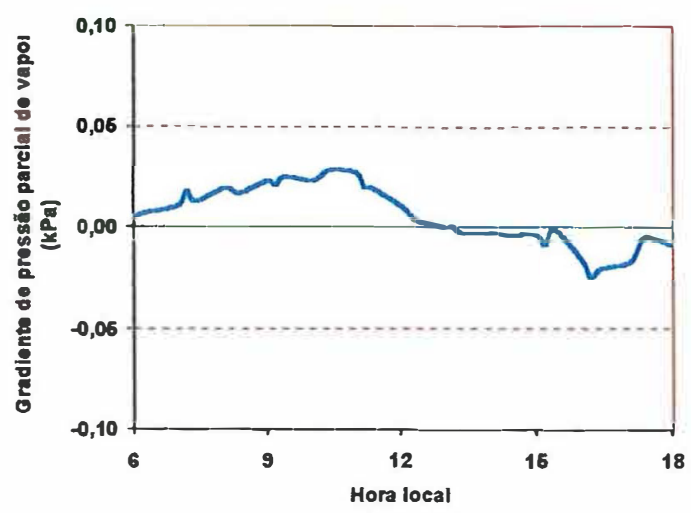

(b)



Figura 46 - Variação no período diurno do gradiente de pressão parcial do vapor aos 11 dias após transplantio, no primeiro cultivo (a) e aos 12 dias após transplantio, no segundo cultivo da alface (b), em Piracicaba, SP, no ano de 2000. 
$\mathrm{Na}$ realidade, o que pode se deduzir, a partir desses cultivos da alface, é que em ambiente protegido é dificil medir gradientes de pressão parcial do vapor, devido à baixa renovação das camadas de ar, em função da baixa velocidade do vento e da pequena atividade convectiva em seu interior. Como o sistema razão de Bowen requer consideráveis gradientes de pressão parcial do vapor para o seu adequado funcionamento (Perez et al., 1999), a sua utilização para a estimativa da evapotranspiração da cultura no interior do ambiente protegido é dificultada. Em consequência, o SRB não apresentou bom desempenho na estimativa da ETc, quando os sensores foram colocados a 0,25 e $1,25 \mathrm{~m}$ acima da cultura. Esse resultado difere dos obtidos em ambiente externo por Tanner et al. (1987), Nie et al. (1992), Azevedo (1999) e Silva (2000), ressaltando que a céu aberto, em oposição ao ambiente protegido, o SRB já foi adotado por diversos autores (Malek, 1993; Allen et al., 1994; Bland et al., 1996; Malek et al., 1997; Rosset et al., 1997) como método padrão.

Ressalta-se que maiores diferenças térmicas e de pressão parcial do vapor devem ser conseguidas com o aumento da distância entre sensores do SRB. Talvez, esse aumento possa possibilitar variações nos gradientes de temperatura e pressão do vapor. Assim sendo, se o gradiente de pressão parcial do vapor tiver relativamente um maior aumento a ETc estimada pelo SRB tenderá a se aproximar da ETc medida pelo lisímetro de pesagem. Caso contrário, os valores medidos e estimados se distanciarão. Em virtude disso, recomenda-se, visando a uma análise mais ampla do desempenho do SRB no interior do ambiente protegido, estudos futuros com distâncias entre os sensores diferenciadas da utilizada nesse trabalho.

\section{4 Índices fisiológicos}

As variações do índice de área foliar (IAF), para o primeiro e o segundo cultivos, podem ser observadas na Figura 47. Analisando-se a variação do referido índice, percebe-se que este apresenta, em ambos os cultivos, valores superiores a 5,0, no início da colheita. A colheita no primeiro cultivo foi iniciada aos $31 \mathrm{DAT}$, ao passo que, no segundo cultivo, somente aos 43 DAT. O acréscimo de 12 dias na duração do 
segundo cultivo deveu-se ao menor saldo de radiação e temperatura do ar neste cultivo, visto que este foi realizado na estação do inverno, enquanto o primeiro foi realizado no outono. Essa menor disponibilidade de radiação solar e temperatura do ar deve ter diminuído a intensidade dos diversos processos dependentes destas, dentre eles a fotossíntese. Em conseqüência, as plantas do segundo cultivo apresentaram crescimento mais lento, como pode ser observado na Figura 48, de acordo com as variações da taxa de crescimento (TCC) observada nos dois cultivos da alface. Essa menor taxa de crescimento da alface, no segundo cultivo, foi devida à menor produção de fotoassimilados. Ressalta-se que, apesar da menor taxa de crescimento ocorrida no segundo cultivo, os valores do índice de área foliar, em ambos os cultivos, foram crescentes até o início da colheita, o que coincidiu com as observações experimentais realizadas a céu aberto por Hamada (1993) e Bastos (1994).

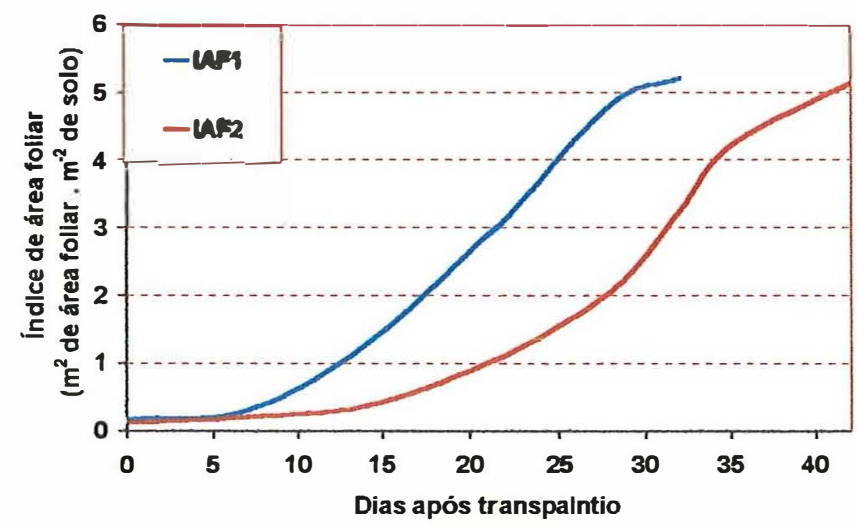

Figura 47 - Índice de área foliar da alface, no primeiro (IAF1) e no segundo (IAF2) cultivos, em Piracicaba, SP, no ano de 2000.

Observa-se, ainda na Figura 48, que a cultura da alface apresentou as maiores taxa de crescimento, no primeiro cultivo, próximo aos $28 \mathrm{DAT}$, e no segundo cultivo, somente aos 35 DAT, demonstrando o crescimento mais lento da alface nesse cultivo. Em ambos os cultivos, ficaram caracterizadas três fases: uma inicial de crescimento lento, uma intermediária de crescimento acelerado e uma final com menores 
taxas de crescimento do que a intermediária. Hamada (1993) e Bastos (1994) também observaram estas três fases de crescimento para a alface. No primeiro cultivo as três fases citadas compreenderam, respectivamente, os períodos entre os DAT, 0 e $14 ; 15$ e 28 e acima de 28, respectivamente. Para o segundo cultivo os períodos foram: 0 e $21 ; 22$ e 35 e acima de 35 DAT, respectivamente, para as fases inicial, intermediária e final. Ressalta-se que não foram analisados os períodos do plantio até o transplantio e após o início da colheita.

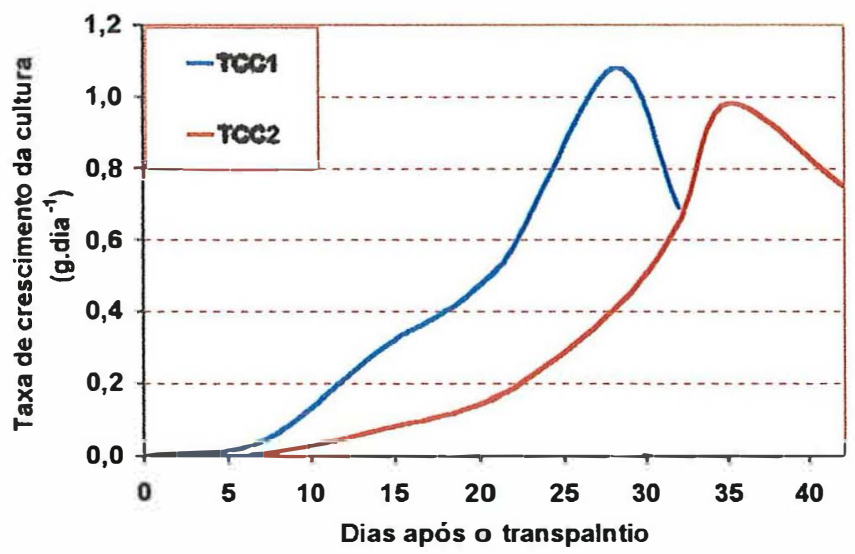

Figura 48 - Taxa de crescimento da cultura da alface, no primeiro (TCC1) e no segundo (TCC2) cultivos, em Piracicaba, SP, no ano de 2000.

Na Figura 49 pode-se observar a variação da taxa de crescimento relativo (TCR), no primeiro e no segundo cultivos. Segundo Briggs et al. (1920), a taxa de crescimento relativo revela a eficiência das plantas em acumular matéria seca. Observou-se que, até os 14 DAT, em ambos os cultivos, os acúmulos relativos de matéria seca foram crescentes, e, a partir daí, decresceram, ou seja, a alface foi mais eficiente em acumular matéria seca na sua fase inicial. As maiores taxas de TCR ocorreram no primeiro cultivo, mostrando um desenvolvimento mais rápido da alface nesse cultivo, entretanto, após os 21 DAT, ocorreram no segundo cultivo maiores taxas, em comparação com o primeiro cultivo, provavelmente porque em função do menor 
peso das plantas neste cultivo, acréscimos absolutos menores de matéria seca possibilitavam acréscimos relativos maiores.

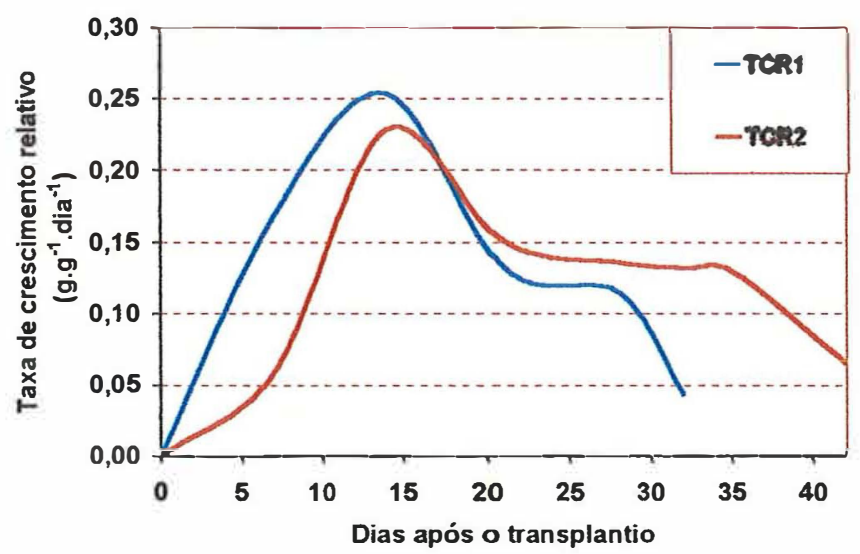

Figura 49 - Taxa de crescimento relativo da alface, no primeiro (TCR1) e no segundo (TCR2) cultivos, em Piracicaba, SP, no ano de 2000.

As variações da taxa de assimilação líquida (TAL) no primeiro e no segundo cultivos podem ser visualizadas na Figura 50. A TAL representa, segundo Pereira e Machado (1987), o balanço entre os carboidratos produzidos através da fotossíntese e os consumidos pela respiração, indicando a eficiência da planta em produzir novos tecidos. Observou-se que a TAL apresentou valores máximos no primeiro cultivo aos 14 DAT. Tal variação nesse cultivo deveu-se ao rápido crescimento da alface, e por conseqüência da área foliar, proporcionando já aos 14 DAT maiores elevações nas taxas respiratórias. No segundo cultivo, a TAL aumentou lentamente, só atingindo taxas máximas após os 30 DAT, devido ao menor crescimento relativo da alface nesse cultivo. Os resultados obtidos no primeiro cultivo foram semelhantes aos observados por Hamada (1993) e Bastos (1994), a céu aberto, que também estimaram valores mais elevados da TAL na primeira fase de desenvolvimento da alface. 


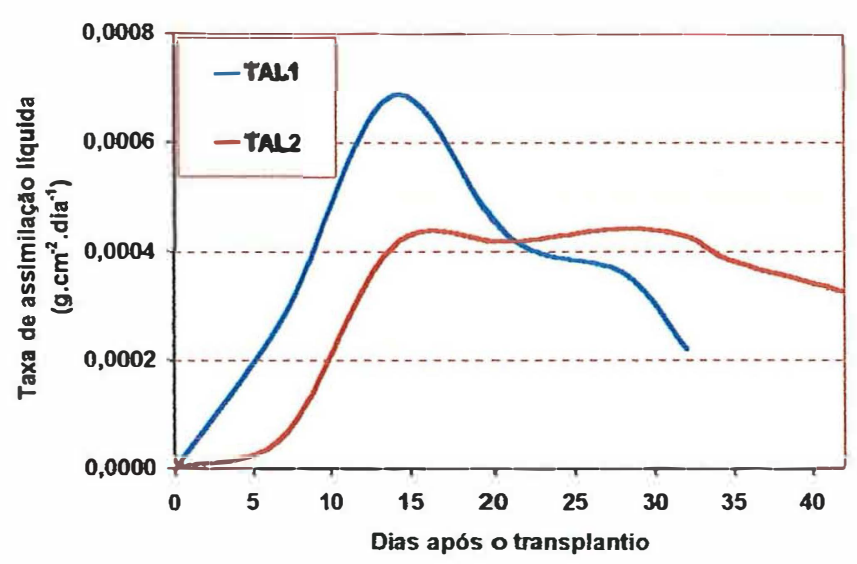

Figura 50 - Taxa de assimilação líquida da alface, no primeiro (TAL1) e no segundo (TAL2) cultivos, em Piracicaba, SP, no ano de 2000.

\subsection{Coeficiente de cultivo}

Estimou-se o coeficiente de cultivo $(\mathrm{Kc})$ para o primeiro e o segundo cultivos, pela relação entre a evapotranspiração da cultura medida no lisímetro de pesagem (ETc) e a evapotranspiração de referência (ETo). Quando o coeficiente de cultivo foi estimado a partir da evapotranspiração de referência calculada com dados observados externamente, foi denominado $\mathrm{Kc}_{(\mathrm{DE})}$. Do mesmo modo, quando estimado a partir de dados internos, foi denominado $\mathrm{Kc}_{(\mathrm{DI})}$. Ressalta-se que, como a evapotranspiração da cultura compreendeu o somatório das variações de peso no lisímetro durante o período diurno, considerou-se, também, somente o período diurno na quantificação da evapotranspiração de referência.

Os coeficientes de cultivo são apresentados em valores médios para cada 5 dias, ou seja, por qüinqüídios. Podem-se visualizar na Figura 51 e nos Anexos 24 e 25 os valores de $\mathrm{Kc}_{(\mathrm{DE})}$ e $\mathrm{Kc}_{(\mathrm{DI})}$ por qüinqüídios, no primeiro (a) e no segundo (b) cultivos. Observa-se que os valores de $\mathrm{Kc}_{(\mathrm{DE})}$ foram sempre inferiores aos de $\mathrm{Kc}_{(\mathrm{DI})}$, nos dois cultivos. Tal resposta deveu-se ao fato de os valores da evapotranspiração de referência estimada com dados externos terem sido sempre superiores aos valores obtidos no interior do ambiente protegido. 
No primeiro cultivo, o valor de $\mathrm{Kc}_{(\mathrm{DE})}$ foi menor no segundo qüinqüídio $(0,76)$ e depois aumentou com o desenvolvimento da alface, sendo de 0,97 no sexto qüinqüídio. Bastos (1994) também encontrou coeficientes de cultivo crescentes com o desenvolvimento da alface, principalmente após os 19 DAT. Os valores de $\mathrm{Kc}_{\text {(DI) }}$ cresceram continuamente desde 0,99 , no primeiro qüinqüídio, até 1,32 , no sexto valor médio. Ressalta-se que o sexto valor médio não representa um qüinqüídio, e sim uma média dos seis últimos valores diários, uma vez que também foi agrupado o valor obtido aos 31 DAT. A tendência crescente e contínua, obtida com $\mathrm{Kc}_{(\mathrm{DI})}$, coincide com a obtida, a céu aberto, por Hamada (1993), e proposta por Doorembos \& Pruitt (1977), para o coeficiente de cultivo da alface, do transplantio até o início da colheita.

(a)

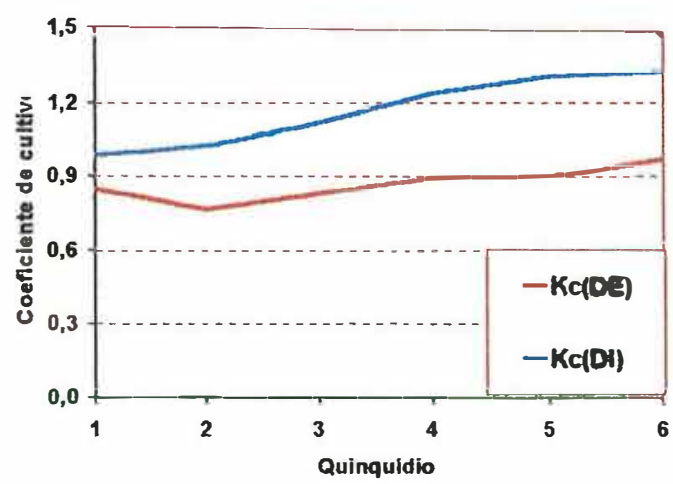

(b)

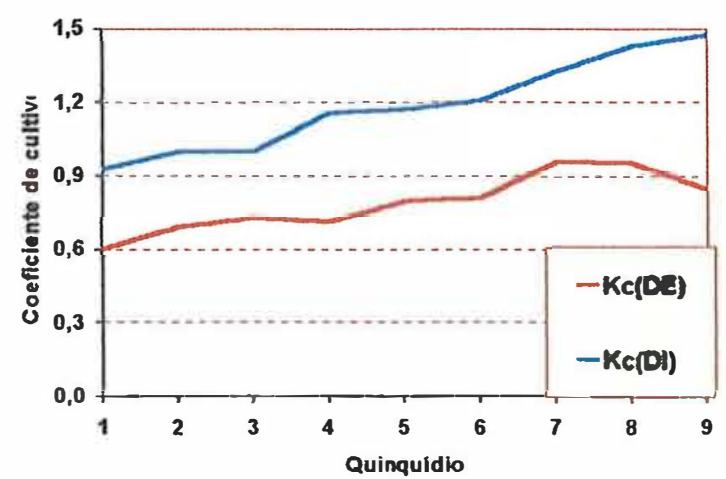

Figura 51 - Valores do coeficiente de cultivo da alface, estimado com dados meteorológicos externos $\left(\mathrm{Kc}_{(\mathrm{DE})}\right)$ e internos $\left(\mathrm{Kc}_{(\mathrm{DI})}\right)$, por qüinqüídio, no primeiro (a) e no segundo (b) cultivos, em Piracicaba, SP, no ano de 2000 .

Os valores do $\mathrm{Kc}_{(\mathrm{DE})}$, no segundo cultivo, oscilaram de 0,60 , no primeiro qüinqüídio a 0,96 , no sétimo (Figura 51 b). Do mesmo modo que no primeiro cultivo, não ocorreu um continuo aumento do $\mathrm{Kc}_{(\mathrm{DE})}$ do transplantio até a colheita. Em oposição, 
os valores de $\mathrm{Kc}_{(\mathrm{DI})}$ foram continuamente crescentes desde 0,93 , no primeiro qüinqüídio, até $1,47,(41$ a 43 DAT $)$.

Observou-se que a tendência dos valores do coeficiente de cultivo obtidos a partir de evapotranspiração de referência estimada dentro e fora do ambiente protegido diferiu, ligeiramente, nos dois cultivos. Enquanto os valores de $\mathrm{Kc}_{(\mathrm{DI})}$ mostraram sempre uma tendência de crescimento persistente, os valores de $\mathrm{Kc}_{(\mathrm{DE})}$ mostraram uma tendência crescente, porém não persistente, ocorrendo elevações e reduções no seu valor por qüinqüídio, ao longo dos dois cultivos. Provavelmente, tais variações divergentes podem ser originadas do fato de as variações diurnas do regime de ventos influenciarem menos significativamente a evapotranspiração no interior do ambiente protegido, dificultando a estimativa do coeficiente de cultivo para condições internas a partir dos dados externos.

Podem ser observados na Figura 52 (a) os valores de $\mathrm{Kc}_{(\mathrm{DE})}$ por fase fisiológica, para os dois cultivos da alface. No primeiro cultivo, obteve-se, respectivamente, para as fases inicial, intermediária e final, os seguintes valores de $\mathrm{Kc}_{(\mathrm{DE})}: 0,80,0,90$ e 0,94 . Na mesma seqüência de fase, os valores para o segundo cultivo foram: $0,69,0,86$ e 0,91 . Já os valores de $\mathrm{Kc}_{(\mathrm{DI})}$ para as referidas fases no primeiro cultivo foram, respectivamente, $1,02,1,29$ e 1,45. No segundo cultivo apresentaram os seguintes valores: 1,02, 1,24 e 1,44, respectivamente, nas fases inicial, intermediária e final.

Os valores do $\mathrm{Kc}_{(\mathrm{DE}}$ por fase apresentaram uma melhor tendência do que os obtidos através de qüinqüídios pois, em oposição ao modo anterior, apresentaram valores continuadamentes crescentes com o desenvolvimento da cultura, conforme proposto por Doorembos \& Pruitt (1977), para cultivos da alface a céu aberto. Entretanto, os valores de $\mathrm{Kc}_{(\mathrm{DE})}$ por fase nos dois cultivos divergiram mais que os valores de $\mathrm{Kc}_{(\mathrm{DI})}$ para os mesmos cultivos e fases. Isso realça comentário anterior de que os valores de coeficiente de cultivo, para uso em ambiente protegido, devem apresentar valores mais consistentes quando calculados a partir de elementos meteorológicos internos. 
(a)

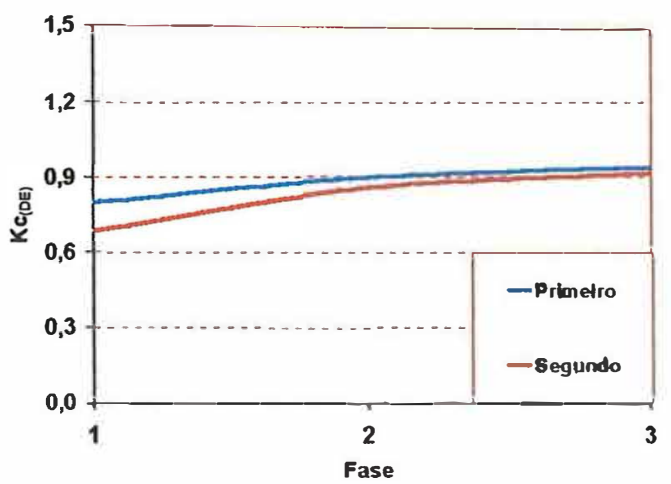

(b)

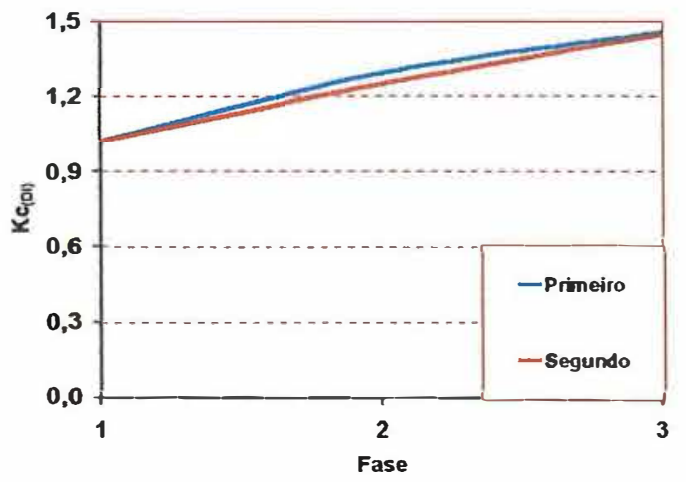

Figura 52 - Valores do coeficiente de cultivo da alface, obtido com dados meteorológicos externos $\left(\mathrm{Kc}_{(\mathrm{DE})}\right)$ e internos $\left(\mathrm{Kc}_{(\mathrm{DI})}\right)$, por fase, no primeiro (a) e no segundo (b) cultivos, em Piracicaba, SP, no ano de 2000 . 


\section{CONCLUSÕES}

A partir dos resultados obtidos nos dois cultivos da alface e discutidos neste trabalho, obtiveram-se as seguintes conclusões:

a) A cobertura plástica afetou os elementos meteorológicos diminuindo o saldo de radiação, a velocidade do vento e a evapotranspiração de referência, e aumentando a temperatura máxima do ar;

b) $\mathrm{O}$ total evapotranspirado pela alface foi de 102,98 e $92,93 \mathrm{~mm}$, respectivamente, para o primeiro e o segundo cultivo. O SRB subestimou esses valores, representando $75,9 \%$ e $66,3 \%$ do total medido no lisímetro de pesagem, respectivamente, no primeiro e no segundo cultivo da alface;

c) A correlação dos dados diários mostrou que o SRB não apresentou um bom desempenho na estimativa da evapotranspiração no interior do ambiente protegido. A redução da velocidade do vento e a contenção dos movimentos convectivos pela cobertura plástica diminuem a renovação das camadas de ar no interior do ambiente protegido. Isso origina baixos valores de gradiente de pressão parcial do vapor e dificulta a estimativa da ETc pelo SRB;

d) No interior do ambiente protegido o SRB necessita de menor manutenção do que no ambiente externo, devido à inexistência de chuvas, ventos fortes, geadas, etc. Entretanto, O SRB não se mostrou capaz de substituir o lisímetro de pesagem na medição da ETc nesse meio, quando os sensores foram colocados a 0,25 e $1,25 \mathrm{~m}$ acima da cultura. Recomenda-se, estudos futuros com sensores do SRB colocados a uma maior distância, visando a comprobação desses resultados. 
ANEXOS

Parte A - Figuras 
Anexo 1 - Calibração do lisímetro de pesagem realizada em campo, oito meses após o seu preenchimento com solo, em Piracicaba, SP, no ano de 2000.

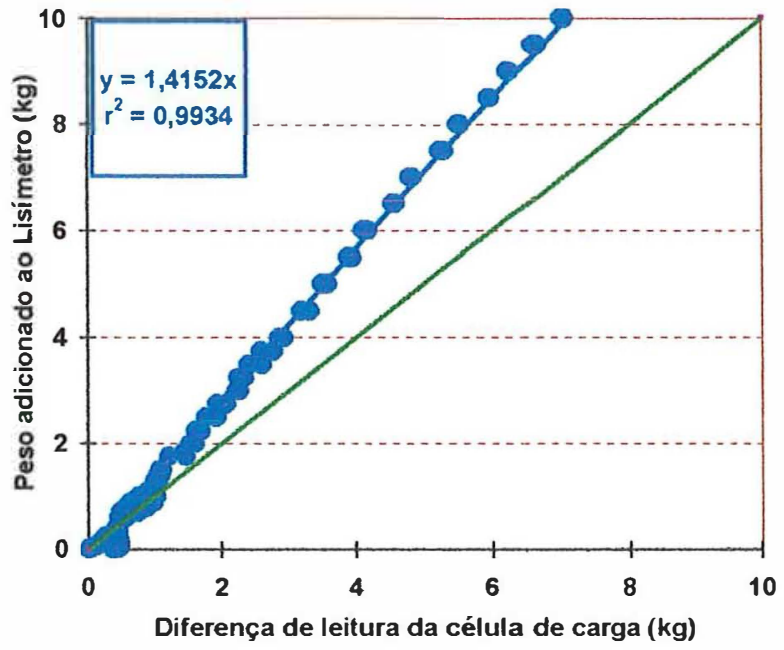

Anexo 2 - Variação do peso do lisímetro $(\mathrm{kg})$, plantado com a alface, ao longo do dia Juliano 177, no qual não ocorreu irrigação, em Piracicaba, SP, no ano de 2000 .

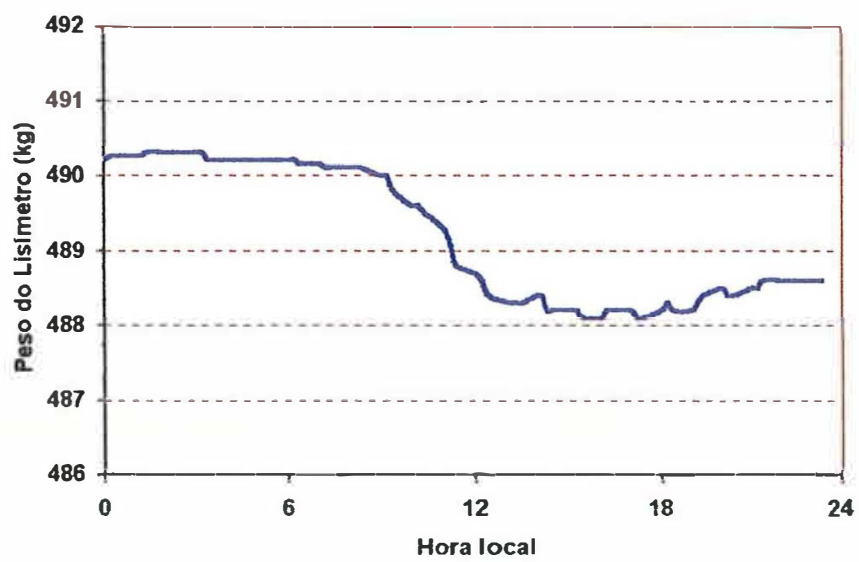


Anexo 3 - Variação do peso do lisímetro $(\mathrm{kg})$, plantado com a alface, ao longo do dia Juliano 178, no qual ocorreu irrigação, em Piracicaba, SP, no ano de 2000.

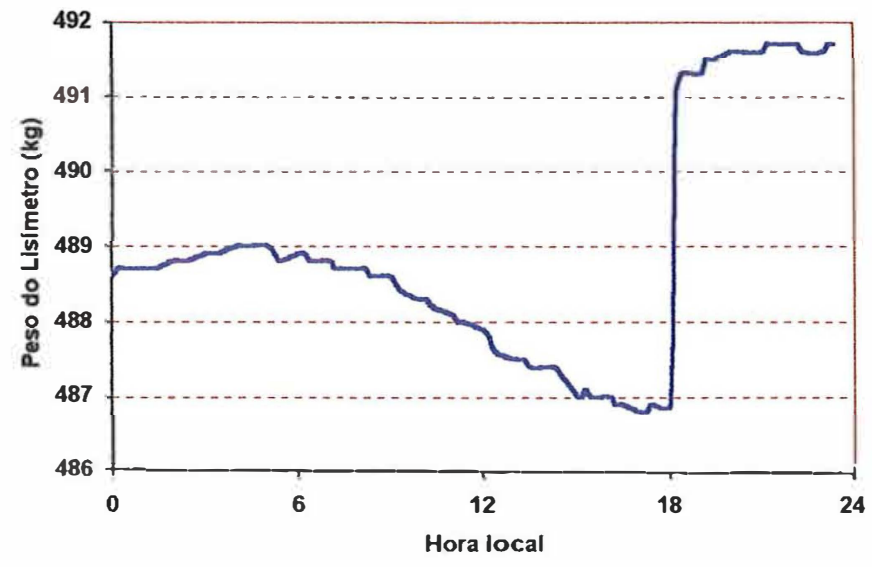

Anexo 4 - Correlação entre os valores da evapotranspiração de referência (ETo, em mm. dia ${ }^{-1}$ ) estimados por dois sistemas razão de Bowen, a céu aberto, em Piracicaba, SP, no ano de 2000.

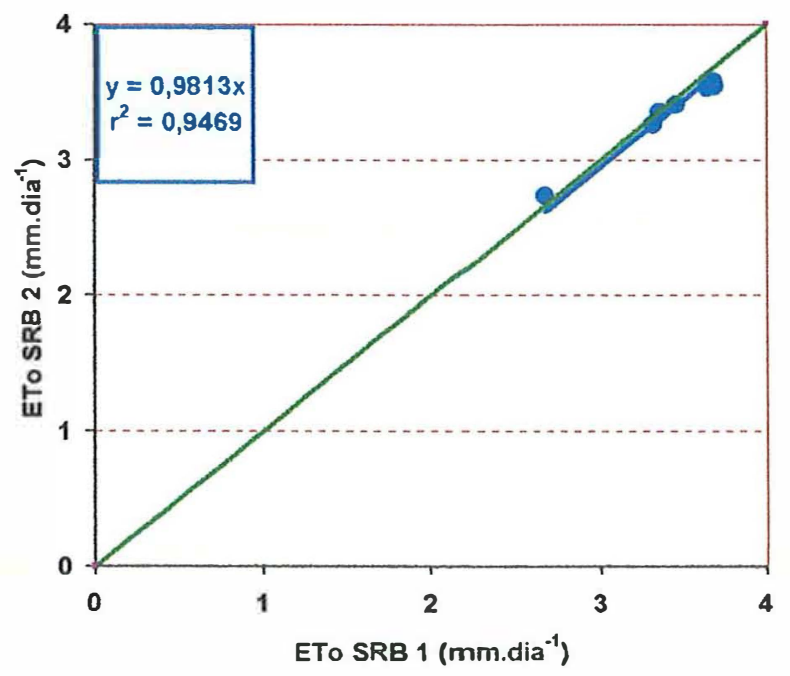


Anexo 5 - Correlação entre os valores da evapotranspiração de referência (ETo, em mm.dia ${ }^{-1}$ ), medidos por um lisímetro de pesagem e estimados por um sistema razão de Bowen, em Piracicaba, SP, no ano de 2000.

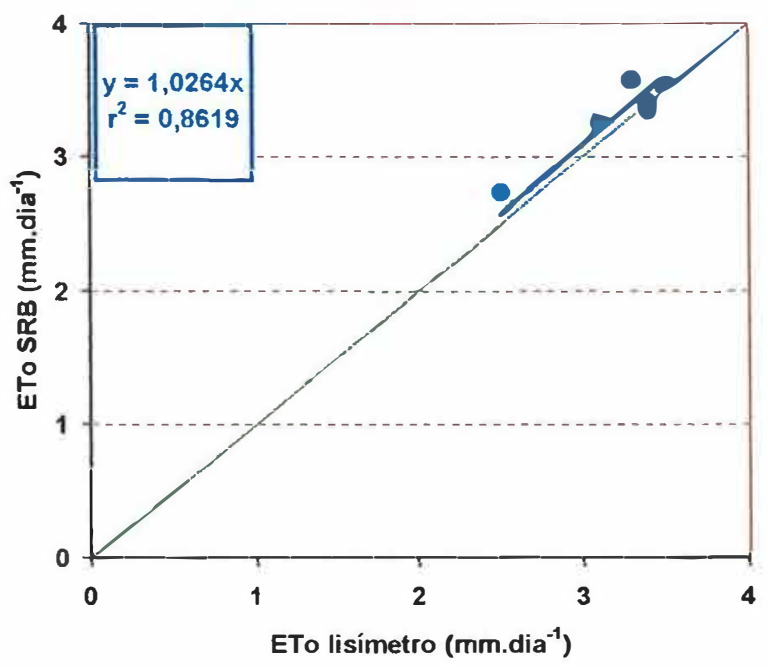


ANEXOS

Parte B - Tabelas 


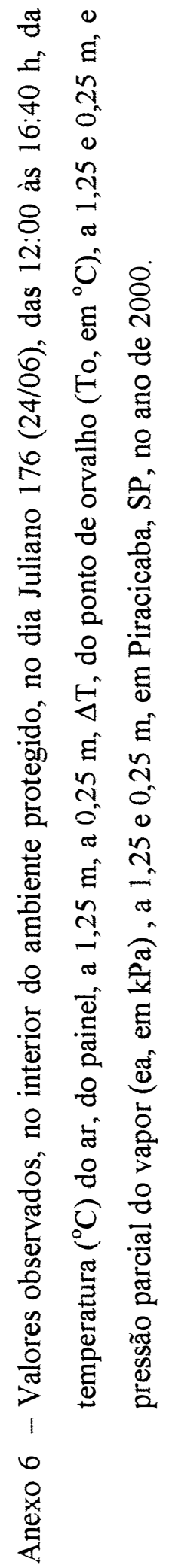

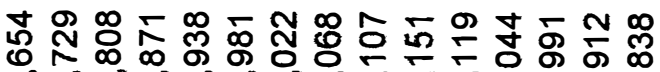

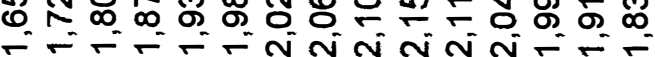

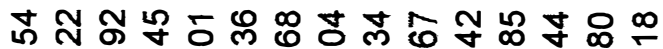

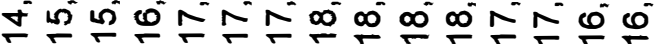

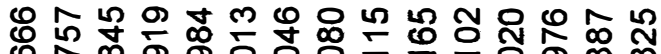
0 -

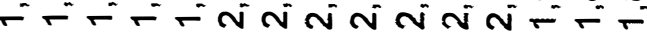

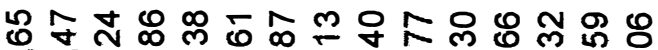

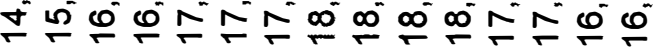

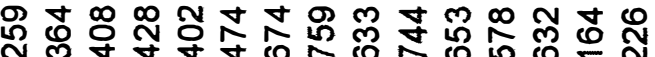
ó ó ó ó ó ó ó ó ó ó

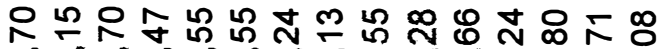
సิ N

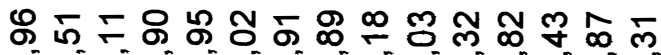
ล N

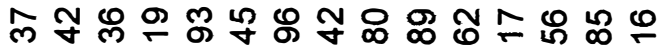

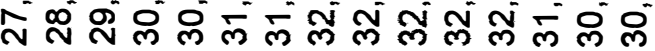

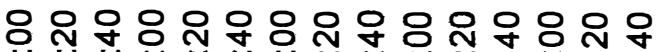

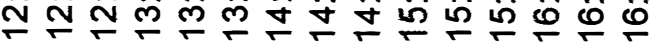

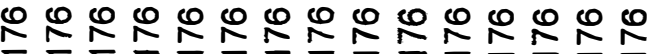

hthththththth

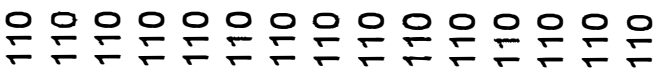




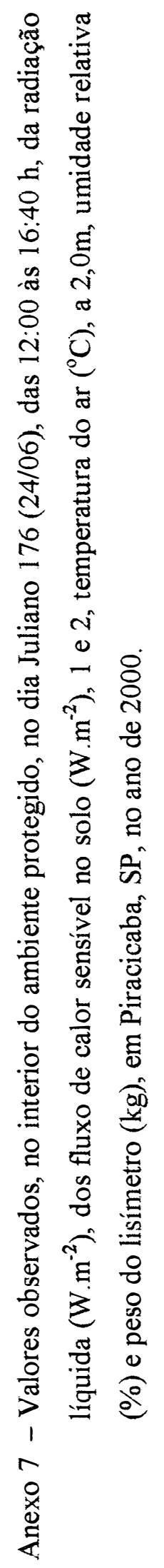

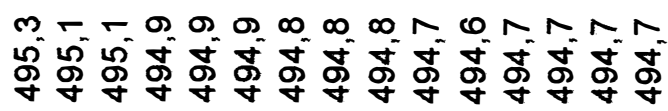

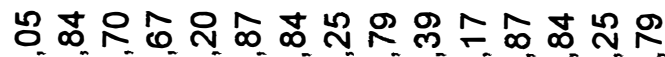
ตั

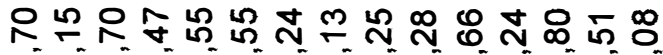

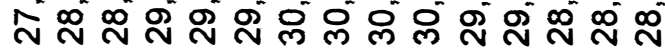

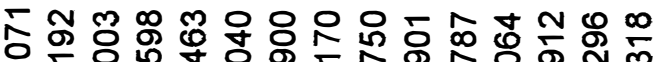
กั

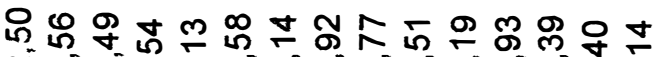
กับง

$\forall$ on

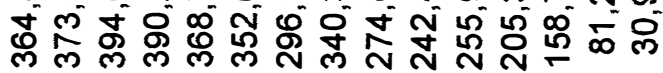

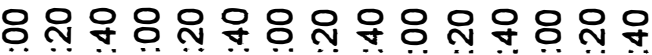

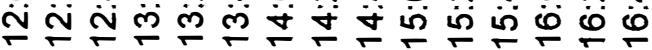

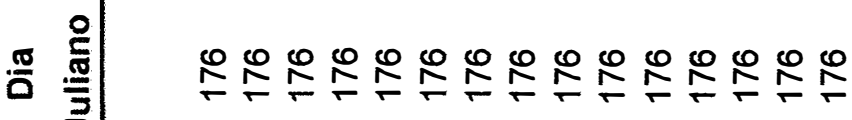

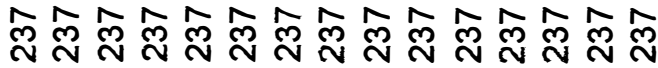




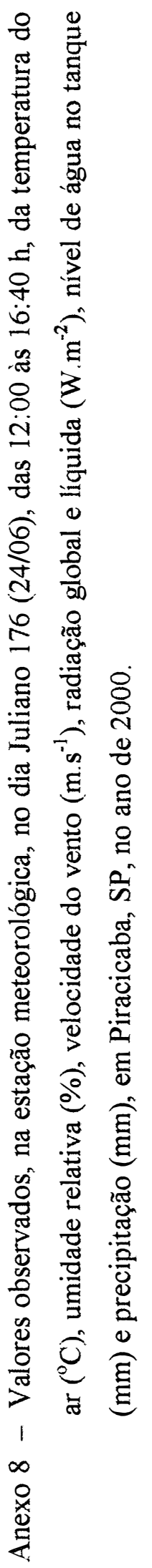

000000000000000

-

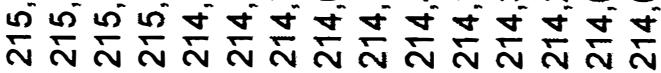

m. 幽

\& ฟิ ฮิ ชิ


ल

กิ่า ఫ

0 ผ

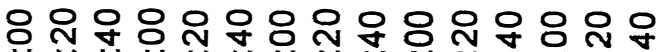

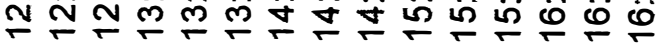
泀

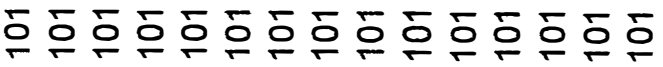


œ ๓

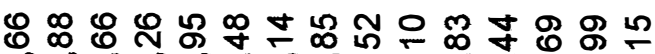



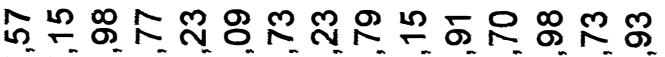
ベกี

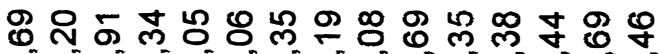
ஸே

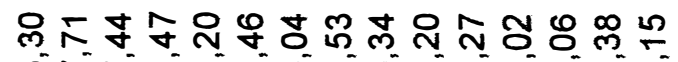
๓ก์

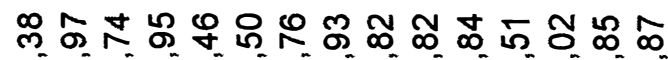
뭉

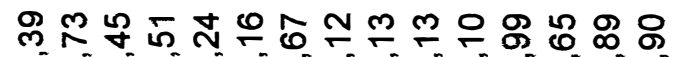

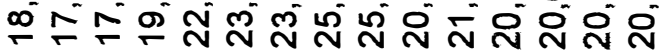

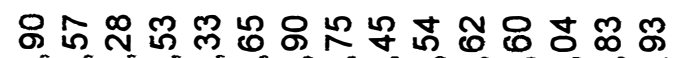
은

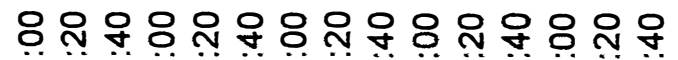
ஸ்



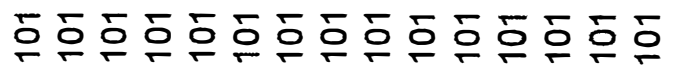


Anexo 10 - Saldo de radiação $(R n)$ e radiação solar global $(\mathrm{Rg})$, diários, obtidos no interior do ambiente protegido e na estação meteorológica, e relações decorrentes, ao longo do primeiro cultivo da alface, em Piracicaba, SP, no ano de 2000.

\begin{tabular}{|c|c|c|c|c|c|c|c|c|c|}
\hline \multirow{3}{*}{ DAT } & \multirow{3}{*}{$\begin{array}{c}\text { Dia } \\
\text { Juliano }\end{array}$} & \multicolumn{8}{|c|}{ Total de radiação $\left(\mathrm{MJ} \mathrm{m}^{-2} \cdot \mathrm{dia}^{-1}\right)$} \\
\hline & & \multicolumn{3}{|c|}{ Ambiente protregido } & \multicolumn{3}{|c|}{ Estação Meteorológica } & \multicolumn{2}{|c|}{ Amb. prot./Estação } \\
\hline & & $\mathbf{R n}$ & $\mathbf{R g}$ & Rn/Rg & $\mathbf{R n}$ & $\mathbf{R g}$ & $\mathbf{R n} / \mathbf{R g}$ & Rn/Rn & $\mathbf{R n} / \mathbf{R g}$ \\
\hline 1 & 98 & 9,47 & 15,20 & 0,62 & 9,73 & 19,08 & 0,51 & 0,97 & 0,50 \\
\hline 2 & 99 & 8,59 & 14,22 & 0,60 & 9,17 & 17,84 & 0,51 & 0,94 & 0,48 \\
\hline 3 & 100 & 9,35 & 15,25 & 0,61 & 9,67 & 19,14 & 0,51 & 0,97 & 0,49 \\
\hline 4 & 101 & 9,47 & 15,75 & 0,60 & 10,92 & 19,76 & 0,55 & 0,87 & 0,48 \\
\hline 5 & 102 & 9,16 & 14,98 & 0,61 & 9,73 & 18,80 & 0,52 & 0,94 & 0,49 \\
\hline 6 & 103 & 9,77 & 16,08 & 0,61 & 11,08 & 20,17 & 0,55 & 0,88 & 0,48 \\
\hline 7 & 104 & 8,72 & 14,12 & 0,62 & 10,09 & 17,72 & 0,57 & 0,86 & 0,49 \\
\hline 8 & 105 & 9,33 & 15,31 & 0,61 & 11,03 & 19,20 & 0,57 & 0,85 & 0,49 \\
\hline 9 & 106 & 9,06 & 15,04 & 0,60 & 9,90 & 18,87 & 0,52 & 0,91 & 0,48 \\
\hline 10 & 107 & 8,88 & 15,93 & 0,56 & 10,22 & 19,98 & 0,51 & 0,87 & 0,44 \\
\hline 11 & 108 & 8,23 & 14,04 & 0,59 & 9,41 & 17,62 & 0,53 & 0,87 & 0,47 \\
\hline 12 & 109 & 4,54 & 8,06 & 0,56 & 5,07 & 10,11 & 0,50 & 0,90 & 0,45 \\
\hline 13 & 110 & 5,83 & 9,79 & 0,60 & 7,37 & 12,29 & 0,60 & 0,79 & 0,47 \\
\hline 14 & 111 & 9,00 & 16,03 & 0,56 & 10,42 & 20,11 & 0,52 & 0,86 & 0,45 \\
\hline 15 & 112 & 8,85 & 15,80 & 0,56 & 10,21 & 19,82 & 0,51 & 0,87 & 0,45 \\
\hline 16 & 113 & 6,95 & 13,00 & 0,53 & 8,10 & 16,31 & 0,50 & 0,86 & 0,43 \\
\hline 17 & 114 & 8,57 & 15,20 & 0,56 & 10,27 & 19,07 & 0,54 & 0,84 & 0,45 \\
\hline 18 & 115 & 8,24 & 14,81 & 0,56 & 9,68 & 18,58 & 0,52 & 0,85 & 0,44 \\
\hline 19 & 116 & 8,21 & 14,88 & 0,55 & 11,08 & 18,67 & 0,59 & 0,74 & 0,44 \\
\hline 20 & 117 & 7,66 & 14,24 & 0,54 & 9,19 & 17,86 & 0,51 & 0,83 & 0,43 \\
\hline 21 & 118 & 7,75 & 14,38 & 0,54 & 9,33 & 18,04 & 0,52 & 0,83 & 0,43 \\
\hline 22 & 119 & 7,94 & 14,61 & 0,54 & 9,54 & 18,33 & 0,52 & 0,83 & 0,43 \\
\hline 23 & 120 & 7,93 & 14,26 & 0,56 & 9,52 & 17,89 & 0,53 & 0,83 & 0,44 \\
\hline 24 & 121 & 7,04 & 12,98 & 0,54 & 8,70 & 16,29 & 0,53 & 0,81 & 0,43 \\
\hline 25 & 122 & 7,13 & 12,81 & 0,56 & 9,00 & 16,07 & 0,56 & 0,79 & 0,44 \\
\hline 26 & 123 & 6,06 & 11,61 & 0,52 & 8,54 & 14,57 & 0,59 & 0,71 & 0,42 \\
\hline 27 & 124 & 6,52 & 12,14 & 0,54 & 8,69 & 15,23 & 0,57 & 0,75 & 0,43 \\
\hline 28 & 125 & 6,53 & 12,12 & 0,54 & 8,77 & 15,21 & 0,58 & 0,74 & 0,43 \\
\hline 29 & 126 & 6,61 & 12,05 & 0,55 & 7,63 & 15,11 & 0,50 & 0,87 & 0,44 \\
\hline 30 & 127 & 3,62 & 6,89 & 0,53 & 3,92 & 8,65 & 0,45 & 0,92 & 0,42 \\
\hline \multirow[t]{2}{*}{31} & 128 & 6,03 & 11,53 & 0,52 & 6,95 & 14,47 & 0,48 & 0,87 & 0,42 \\
\hline & $\begin{array}{l}\text { Média } \\
\text { Total }\end{array}$ & $\begin{array}{r}7,78 \\
241,03\end{array}$ & $\begin{array}{c}13,65 \\
423,08\end{array}$ & 0,57 & $\begin{array}{c}9,13 \\
282,93\end{array}$ & $\begin{array}{c}17,12 \\
530,84\end{array}$ & 0,53 & 0,85 & 0,45 \\
\hline
\end{tabular}


Anexo 11 - Saldo de radiação $(R n)$ e radiação solar global $(R g)$, diários, obtidos no interior do ambiente protegido e na estação meteorológica, e relações decorrentes, ao longo do segundo cultivo da alface, em Piracicaba, SP, no ano de 2000.

\section{Total de radiação (MJ.m ${ }^{-2} \cdot$ dia $^{-1}$ )}

\begin{tabular}{|c|c|c|c|c|c|c|c|c|c|}
\hline \multirow[t]{2}{*}{ DAT } & \multirow{2}{*}{$\begin{array}{c}\text { Dia } \\
\text { Juliano } \\
\end{array}$} & \multicolumn{3}{|c|}{ Ambiente protegido } & \multicolumn{3}{|c|}{ Estação Meteorológica } & \multicolumn{2}{|c|}{ Amb. prot./Estação } \\
\hline & & $\mathbf{R n}$ & $\mathbf{R g}$ & $\mathbf{R n} / \mathbf{R g}$ & $\mathbf{R n}$ & $\mathbf{R g}$ & $\mathbf{R n} / \mathbf{R g}$ & Rn/Rn & $\mathbf{R n} / \mathbf{R g}$ \\
\hline 1 & 176 & 6,05 & 11,28 & 0,54 & 6,82 & 14,16 & 0,48 & 0,89 & 0,43 \\
\hline 2 & 177 & 6,38 & 11,35 & 0,56 & 7,17 & 14,25 & 0,50 & 0,89 & 0,45 \\
\hline 3 & 178 & 5,15 & 9,48 & 0,54 & 6,11 & 11,90 & 0,51 & 0,84 & 0,43 \\
\hline 4 & 179 & 2,76 & 6,06 & 0,46 & 3,34 & 7,60 & 0,44 & 0,83 & 0,36 \\
\hline 5 & 180 & 6,00 & 10,54 & 0,57 & 7,54 & 13,22 & 0,57 & 0,80 & 0,45 \\
\hline 6 & 181 & 5,20 & 9,39 & 0,55 & 5,33 & 11,78 & 0,45 & 0,98 & 0,44 \\
\hline 7 & 182 & 2,08 & 5,36 & 0,39 & 2,11 & 6,72 & 0,31 & 0,98 & 0,31 \\
\hline 8 & 183 & 6,76 & 11,35 & 0,60 & 7,32 & 14,24 & 0,51 & 0,92 & 0,47 \\
\hline 9 & 184 & 6,64 & 11,39 & 0,58 & 7,60 & 14,29 & 0,53 & 0,87 & 0,46 \\
\hline 10 & 185 & 4,26 & 8,60 & 0,49 & 5,23 & 10,79 & 0,48 & 0,81 & 0,39 \\
\hline 11 & 186 & 4,88 & 9,43 & 0,52 & 5,75 & 11,84 & 0,49 & 0,85 & 0,41 \\
\hline 12 & 187 & 6,12 & 10,42 & 0,59 & 7,12 & 13,07 & 0,55 & 0,86 & 0,47 \\
\hline 13 & 188 & 5,87 & 10,55 & 0,56 & 6,97 & 13,24 & 0,53 & 0,84 & 0,44 \\
\hline 14 & 189 & 5,62 & 10,25 & 0,55 & 6,45 & 12,86 & 0,50 & 0,87 & 0,44 \\
\hline 15 & 190 & 4,33 & 8,85 & 0,49 & 5,59 & 11,10 & 0,50 & 0,77 & 0,39 \\
\hline 16 & 191 & 6,21 & 10,95 & 0,57 & 7,57 & 13,74 & 0,55 & 0,82 & 0,45 \\
\hline 17 & 192 & 6,09 & 11,32 & 0,54 & 7,55 & 14,20 & 0,53 & 0,81 & 0,43 \\
\hline 18 & 193 & 4,76 & 8,58 & 0,55 & 5,90 & 10,77 & 0,55 & 0,81 & 0,44 \\
\hline 19 & 194 & 1,80 & 4,73 & 0,38 & 2,66 & 5,94 & 0,45 & 0,68 & 0,30 \\
\hline 20 & 195 & 5,22 & 11,24 & 0,46 & 6,18 & 14,11 & 0,44 & 0,84 & 0,37 \\
\hline 21 & 196 & 5,77 & 11,28 & 0,51 & 6,99 & 14,15 & 0,49 & 0,82 & 0,41 \\
\hline 22 & 197 & 2,14 & 4,81 & 0,44 & 3,03 & 6,03 & 0,50 & 0,70 & 0,35 \\
\hline 23 & 198 & 6,25 & 12,13 & 0,52 & 8,10 & 15,22 & 0,53 & 0,77 & 0,41 \\
\hline 24 & 199 & 6,05 & 13,06 & 0,46 & 6,75 & 16,39 & 0,41 & 0,90 & 0,37 \\
\hline 25 & 200 & 4,73 & 10,29 & 0,46 & 5,67 & 12,91 & 0,44 & 0,83 & 0,37 \\
\hline 26 & 201 & 2,09 & 5,00 & 0,42 & 2,92 & 6,27 & 0,47 & 0,71 & 0,33 \\
\hline 27 & 202 & 3,93 & 9,33 & 0,42 & 4,27 & 11,71 & 0,36 & 0,92 & 0,34 \\
\hline 28 & 203 & 6,70 & 12,49 & 0,54 & 7,68 & 15,67 & 0,49 & 0,87 & 0,43 \\
\hline 29 & 204 & 4,00 & 6,95 & 0,58 & 5,04 & 8,72 & 0,58 & 0,79 & 0,46 \\
\hline 30 & 205 & 0,45 & 1,58 & 0,28 & 0,81 & 1,98 & 0,41 & 0,55 & 0,23 \\
\hline 31 & 206 & 5,09 & 9,95 & 0,51 & 6,18 & 12,49 & 0,50 & 0,82 & 0,41 \\
\hline 32 & 207 & 5,67 & 11,01 & 0,51 & 6,82 & 13,82 & 0,49 & 0,83 & 0,41 \\
\hline 33 & 208 & 5,38 & 10,11 & 0,53 & 6,62 & 12,69 & 0,52 & 0,81 & 0,42 \\
\hline 34 & 209 & 6,19 & 12,60 & 0,49 & 8,18 & 15,81 & 0,52 & 0,76 & 0,39 \\
\hline 35 & 210 & 6,78 & 12,88 & 0,53 & 8,32 & 16,16 & 0,52 & 0,81 & 0,42 \\
\hline
\end{tabular}

Continua ... 
Anexo 11 - Saldo de radiação $(\mathrm{Rn})$ e radiação solar global $(\mathrm{Rg})$, diários, obtidos no interior do ambiente protegido e na estação meteorológica, e relações decorrentes, ao longo do segundo cultivo da alface, em Piracicaba, SP, no ano de 2000.

\begin{tabular}{|c|c|c|c|c|c|c|c|c|c|}
\hline \multirow{3}{*}{ DAT } & \multirow{3}{*}{$\begin{array}{c}\text { Dia } \\
\text { Juliano }\end{array}$} & \multicolumn{8}{|c|}{ Total de radiação $\left(M J \cdot m^{-2} \cdot d^{-1}{ }^{-1}\right)$} \\
\hline & & \multicolumn{3}{|c|}{ Ambiente protegido } & \multicolumn{3}{|c|}{ Estação Meteorológica } & \multicolumn{2}{|c|}{ Amb. prot./Estação } \\
\hline & & $\mathbf{R n}$ & $\mathbf{R g}$ & $\mathbf{R n} / \mathbf{R g}$ & $\mathbf{R n}$ & $\mathbf{R g}$ & $\mathbf{R n} / \mathbf{R g}$ & $\mathbf{R n} / \mathbf{R n}$ & $\mathbf{R n} / \mathbf{R g}$ \\
\hline 36 & 211 & 5,57 & 10,78 & 0,52 & 7,10 & 13,52 & 0,53 & 0,78 & 0,41 \\
\hline 37 & 212 & 6,42 & 12,63 & 0,51 & 8,19 & 15,85 & 0,52 & 0,78 & 0,41 \\
\hline 38 & 213 & 5,79 & 11,47 & 0,51 & 7,41 & 14,39 & 0,51 & 0,78 & 0,40 \\
\hline 39 & 214 & 4,31 & 9,50 & 0,45 & 6,27 & 11,92 & 0,53 & 0,69 & 0,36 \\
\hline 40 & 215 & 4,31 & 9,34 & 0,46 & 7,01 & 11,71 & 0,60 & 0,62 & 0,37 \\
\hline 41 & 216 & 2,57 & 6,36 & 0,40 & 4,25 & 7,98 & 0,53 & 0,60 & 0,32 \\
\hline 42 & 217 & 4,63 & 10,24 & 0,45 & 6,97 & 12,85 & 0,54 & 0,66 & 0,36 \\
\hline 43 & 218 & 4,90 & 12,47 & 0,39 & 7,54 & 15,65 & 0,48 & 0,65 & 0,31 \\
\hline & $\begin{array}{l}\text { Média } \\
\text { Total }\end{array}$ & $\begin{array}{r}4,93 \\
211,85\end{array}$ & $\begin{array}{c}9,71 \\
417,37\end{array}$ & 0,51 & $\begin{array}{r}6,10 \\
262,42\end{array}$ & $\begin{array}{c}12,18 \\
523,68\end{array}$ & 0,50 & 0,81 & 0,40 \\
\hline
\end{tabular}


Anexo 12 - Temperatura média diária $\left({ }^{\circ} \mathrm{C}\right)$, no interior do ambiente protegido e na estação meteorológica, e maiores e menores diferenças térmicas ao longo do dia, no primeiro cultivo da alface, em Piracicaba, SP, no ano de 2000.

\begin{tabular}{|c|c|c|c|c|c|c|c|c|}
\hline \multirow[t]{2}{*}{ DAT } & \multirow{2}{*}{$\begin{array}{c}\text { Dia } \\
\text { Juliano }\end{array}$} & \multicolumn{3}{|c|}{ Temperatura média diária $\left({ }^{\circ} \mathrm{C}\right)$} & \multicolumn{4}{|c|}{ Diferença térmica $\left({ }^{\circ} \mathrm{C}\right)$} \\
\hline & & Amb. prot. & Estação & Amb./est. & Maior* & Horário & Menor** & Horário \\
\hline 1 & 98 & 24,09 & 22,51 & 1,07 & 6,08 & $12: 00$ & $-1,36$ & $2: 20$ \\
\hline 2 & 99 & 24,68 & 23,57 & 1,05 & 6,89 & $14: 00$ & $-0,72$ & $2: 40$ \\
\hline 3 & 100 & 25,31 & 24,08 & 1,05 & 6,92 & $15: 20$ & $-2,18$ & $2: 00$ \\
\hline 4 & 101 & 25,52 & 23,97 & 1,06 & 6,42 & $13: 20$ & $-2,29$ & $7: 20$ \\
\hline 5 & 102 & 24,80 & 23,64 & 1,05 & 5,13 & $12: 20$ & $-2,20$ & $7: 00$ \\
\hline 6 & 103 & 23,47 & 22,40 & 1,05 & 4,81 & $12: 00$ & $-1,97$ & $6: 40$ \\
\hline 7 & 104 & 23,95 & 23,22 & 1,03 & 3,83 & $10: 20$ & $-0,27$ & $20: 00$ \\
\hline 8 & 105 & 24,45 & 23,82 & 1,03 & 4,25 & $14: 20$ & $-2,08$ & $7: 00$ \\
\hline 9 & 106 & 24,66 & 23,86 & 1,03 & 4,73 & $12: 00$ & $-2,43$ & $7: 20$ \\
\hline 10 & 107 & 22,52 & 21,91 & 1,03 & 4,10 & $13: 20$ & $-1,21$ & $7: 20$ \\
\hline 11 & 108 & 22,31 & 21,17 & 1,05 & 5,86 & $12: 40$ & $-0,92$ & $19: 40$ \\
\hline 12 & 109 & 22,74 & 21,77 & 1,04 & 4,22 & $12: 40$ & $-0,27$ & $2: 20$ \\
\hline 13 & 110 & 24,12 & 23,23 & 1,04 & 3,62 & $11: 00$ & $-0,12$ & $4: 00$ \\
\hline 14 & 111 & 21,49 & 20,89 & 1,03 & 2,93 & $13: 20$ & $-1,80$ & $22: 40$ \\
\hline 15 & 112 & 19,18 & 18,78 & 1,02 & 3,47 & $13: 20$ & $-2,22$ & $21: 40$ \\
\hline 16 & 113 & 19,25 & 18,65 & 1,03 & 3,17 & $11: 40$ & $-0,94$ & $7: 40$ \\
\hline 17 & 114 & 20,11 & 19,02 & 1,06 & 6,39 & $14: 20$ & $-2,34$ & $21: 20$ \\
\hline 18 & 115 & 20,53 & 19,36 & 1,06 & 4,97 & $12: 20$ & $-2,29$ & $20: 40$ \\
\hline 19 & 116 & 20,93 & 19,48 & 1,07 & 7,53 & $12: 20$ & $-0,94$ & $7: 20$ \\
\hline 20 & 117 & 20,05 & 18,94 & 1,06 & 6,17 & $13: 20$ & $-2,33$ & $19: 00$ \\
\hline 21 & 118 & 20,69 & 19,52 & 1,06 & 6,68 & $13: 20$ & $-2,93$ & $6: 40$ \\
\hline 22 & 119 & 21,30 & 20,13 & 1,06 & 5,82 & $14: 00$ & $-0,97$ & $7: 20$ \\
\hline 23 & 120 & 21,42 & 20,10 & 1,07 & 6,17 & $12: 40$ & $-2,34$ & 7:00 \\
\hline 24 & 121 & 22,03 & 21,18 & 1,04 & 6,30 & $14: 00$ & $-0,32$ & $20: 20$ \\
\hline 25 & 122 & 23,40 & 22,39 & 1,05 & 5,59 & $14: 00$ & $-1,96$ & 7:00 \\
\hline 26 & 123 & 22,90 & 21,72 & 1,05 & 7,86 & $13: 00$ & $-0,79$ & $18: 40$ \\
\hline 27 & 124 & 23,86 & 22,67 & 1,05 & 6,10 & $13: 40$ & $-1,27$ & $7: 20$ \\
\hline 28 & 125 & 23,29 & 22,27 & 1,05 & 5,10 & $12: 40$ & $-1,07$ & $18: 40$ \\
\hline 29 & 126 & 23,74 & 23,03 & 1,03 & 5,05 & $14: 40$ & $-2,60$ & $19: 20$ \\
\hline 30 & 127 & 20,98 & 20,83 & 1,01 & 2,51 & $9: 20$ & $-1,67$ & $0: 20$ \\
\hline 31 & 128 & 18,91 & 18,26 & 1,04 & 5,43 & $10: 40$ & $-2,06$ & 7:00 \\
\hline
\end{tabular}

\section{$\begin{array}{llllll}\text { Média } & 22,47 & 21,50 & 1,05 & 5,29 & -1,58\end{array}$}

* Maior superávit entre os valores, médios de 20 minutos, obtidos no interior do ambiente protegido em comparação com os obtidos externamente;

** Maior déficit entre os valores, médios de 20 minutos, obtidos no interior do ambiente protegido em comparação com os obtidos externamente. 
Anexo 13 - Temperatura média diária $\left({ }^{\circ} \mathrm{C}\right)$, no interior do ambiente protegido e na estação meteorológica, e maiores e menores diferenças térmicas ao longo do dia, no segundo cultivo da alface, em Piracicaba, SP, no ano de 2000.

\begin{tabular}{|c|c|c|c|c|c|c|c|c|}
\hline \multirow[t]{2}{*}{ DAT } & \multirow{2}{*}{$\begin{array}{c}\text { Dia } \\
\text { Juliano }\end{array}$} & \multicolumn{3}{|c|}{ Temperatura média diária $\left({ }^{\circ} \mathrm{C}\right)$} & \multicolumn{4}{|c|}{ Diferença térmica $\left({ }^{\circ} \mathrm{C}\right)$} \\
\hline & & Amb. prot. & Estação & Amb.jest. & Maior* & Horário & Menor** & Horário \\
\hline 1 & 176 & 17,74 & 18,23 & 0,97 & 2,41 & $13: 00$ & $-0,42$ & $23: 40$ \\
\hline 2 & 177 & 21,85 & 22,27 & 0,98 & 2,39 & $11: 20$ & $-1,19$ & $2: 00$ \\
\hline 3 & 178 & 21,19 & 20,97 & 1,01 & 5,22 & $13: 20$ & $-1,54$ & $1: 40$ \\
\hline 4 & 179 & 20,62 & 20,51 & 1,01 & 2,91 & $13: 40$ & $-2,91$ & $2: 00$ \\
\hline 5 & 180 & 20,31 & 19,79 & 1,03 & 4,44 & $14: 20$ & $-0,36$ & $23: 00$ \\
\hline 6 & 181 & 20,85 & 21,65 & 0,96 & 2,79 & $11: 20$ & $-1,21$ & $2: 20$ \\
\hline 7 & 182 & 18,10 & 17,85 & 1,01 & 5,34 & $15: 00$ & $-0,68$ & $2: 40$ \\
\hline 8 & 183 & 17,89 & 16,85 & 1,06 & 6,19 & $13: 40$ & $-2,22$ & $18: 40$ \\
\hline 9 & 184 & 19,98 & 19,29 & 1,04 & 4,91 & $13: 40$ & $-0,34$ & $1: 40$ \\
\hline 10 & 185 & 19,58 & 19,28 & 1,02 & 2,90 & $10: 20$ & $-1,25$ & $4: 20$ \\
\hline 11 & 186 & 18,56 & 17,94 & 1,03 & 3,16 & $15: 40$ & $-0,58$ & $22: 40$ \\
\hline 12 & 187 & 18,64 & 17,69 & 1,05 & 5,89 & $14: 20$ & $-2,60$ & $1: 40$ \\
\hline 13 & 188 & 19,34 & 18,36 & 1,05 & 5,31 & $13: 40$ & $-2,30$ & $18: 40$ \\
\hline 14 & 189 & 19,52 & 18,79 & 1,04 & 5,21 & $15: 40$ & $-1,86$ & $6: 40$ \\
\hline 15 & 190 & 19,79 & 19,60 & 1,01 & 5,04 & $13: 20$ & $-2,14$ & $20: 00$ \\
\hline 16 & 191 & 21,62 & 21,14 & 1,02 & 5,32 & $15: 00$ & $-2,34$ & $6: 40$ \\
\hline 17 & 192 & 21,36 & 21,32 & 1,00 & 4,41 & $15: 00$ & $-0,43$ & $22: 40$ \\
\hline 18 & 193 & 23,06 & 22,93 & 1,01 & 3,18 & $10: 40$ & $-2,68$ & $0: 00$ \\
\hline 19 & 194 & 16,82 & 16,30 & 1,03 & 2,35 & $12: 00$ & $-0,27$ & $23: 40$ \\
\hline 20 & 195 & 13,33 & 13,30 & 1,00 & 3,85 & $12: 40$ & $-0,43$ & 7:00 \\
\hline 21 & 196 & 14,63 & 13,87 & 1,05 & 5,29 & $12: 00$ & $-1,86$ & $0: 00$ \\
\hline 22 & 197 & 15,93 & 15,29 & 1,04 & 3,77 & $11: 20$ & $-1,96$ & $8: 40$ \\
\hline 23 & 198 & 15,47 & 14,74 & 1,05 & 2,44 & $11: 40$ & $-0,34$ & $20: 40$ \\
\hline 24 & 199 & 9,16 & 8,40 & 1,09 & 4,45 & $13: 00$ & $-1,46$ & $1: 00$ \\
\hline 25 & 200 & 9,79 & 9,48 & 1,03 & 3,84 & $13: 20$ & $-0,16$ & $7: 00$ \\
\hline 26 & 201 & 11,81 & 11,37 & 1,04 & 3,49 & $12: 00$ & $-1,55$ & 21:00 \\
\hline 27 & 202 & 11,09 & 11,07 & 1,00 & 5,06 & $13: 00$ & $-0,82$ & $2: 00$ \\
\hline 28 & 203 & 12,62 & 12,34 & 1,02 & 4,33 & $12: 40$ & $-1,63$ & $6: 00$ \\
\hline 29 & 204 & 20,17 & 19,73 & 1,02 & 5,32 & $13: 00$ & $-1,71$ & $19: 20$ \\
\hline 30 & 205 & 15,85 & 15,15 & 1,05 & 2,90 & $12: 40$ & $-0,49$ & $0: 00$ \\
\hline 31 & 206 & 12,92 & 12,79 & 1,01 & 3,61 & $11: 20$ & $-0,83$ & $2: 40$ \\
\hline 32 & 207 & 14,04 & 13,71 & 1,02 & 4,53 & $12: 20$ & $-0,78$ & $6: 00$ \\
\hline 33 & 208 & 14,51 & 14,08 & 1,03 & 5,30 & $12: 20$ & $-1,69$ & $1: 40$ \\
\hline 34 & 209 & 16,30 & 15,59 & 1,05 & 4,69 & $12: 00$ & $-2,04$ & $2: 00$ \\
\hline 35 & 210 & 16,32 & 15,85 & 1,03 & 5,66 & $12: 20$ & $-0,32$ & $6: 00$ \\
\hline
\end{tabular}

Continua $\ldots$ 
Anexo 13 - Temperatura média diária $\left({ }^{\circ} \mathrm{C}\right)$, no interior do ambiente protegido e na estação meteorológica, e maiores e menores diferenças térmicas ao longo do dia, no segundo cultivo da alface, em Piracicaba, SP, no ano de 2000.

\begin{tabular}{|c|c|c|c|c|c|c|c|c|}
\hline \multirow[t]{2}{*}{ DAT } & \multirow{2}{*}{$\begin{array}{c}\text { Dia } \\
\text { Juliano }\end{array}$} & \multicolumn{3}{|c|}{ Temperatura média diária $\left({ }^{\circ} \mathrm{C}\right)$} & \multicolumn{4}{|c|}{ Diferença térmica $\left({ }^{\circ}{ }^{\circ}\right.$ ) } \\
\hline & & Amb. prot. & Estação & Amb.lest. & Maior* & Horário & Menor** & Horário \\
\hline 36 & 211 & 15,17 & 15,39 & 0,99 & 3,92 & $11: 20$ & $-0,49$ & $1: 20$ \\
\hline 37 & 212 & 17,46 & 17,44 & 1,00 & 3,57 & $12: 00$ & $-0,57$ & $5: 20$ \\
\hline 38 & 213 & 18,70 & 18,46 & 1,01 & 3,77 & $13: 00$ & $-1,47$ & $6: 00$ \\
\hline 39 & 214 & 18,23 & 18,39 & 0,99 & 1,19 & $11: 20$ & $-1,66$ & 23:00 \\
\hline 40 & 215 & 19,16 & 19,64 & 0,98 & 2,79 & $12: 20$ & $-0,64$ & $1: 20$ \\
\hline 41 & 216 & 18,68 & 18,65 & 1,00 & 1,96 & 9:20 & $-1,39$ & 1:00 \\
\hline 42 & 217 & 16,02 & 15,54 & 1,03 & 4,43 & $13: 00$ & $-2,02$ & $5: 40$ \\
\hline 43 & 218 & 13,52 & 13,16 & 1,03 & 4,13 & $13: 00$ & $-1,00$ & $5: 40$ \\
\hline & Média & 17,16 & 16,84 & 1,02 & 4,04 & & $-1,27$ & \\
\hline
\end{tabular}

* Maior superávit entre os valores, médios de 20 minutos, obtidos no interior do ambiente protegido em comparação com os obtidos externamente;

** Maior déficit entre os valores, médios de 20 minutos, obtidos no interior do ambiente protegido em comparação com os obtidos externamente. 
Anexo 14 - Umidade relativa média diária (\%), no interior do ambiente protegido e na estação meteorológica, e maiores e menores diferenças ao longo do dia, no primeiro cultivo da alface, em Piracicaba, SP, no ano de 2000.

\begin{tabular}{|c|c|c|c|c|c|c|c|c|}
\hline \multirow[t]{2}{*}{ DAT } & \multirow{2}{*}{$\begin{array}{c}\text { Dia } \\
\text { Juliano }\end{array}$} & \multicolumn{3}{|c|}{ Umidade Relativa média (\%) } & Diferença & \multicolumn{3}{|c|}{ (UR Amb. prot - UFR Estaça) } \\
\hline & & Amb. prot. & Estação & Amb./est. & Maior* & Horário & Menor & Horário \\
\hline 1 & 98 & 76,31 & 78,07 & 0,98 & 13,30 & $18: 40$ & $-18,18$ & $12: 00$ \\
\hline 2 & 99 & 72,93 & 74,04 & 0,99 & 13,45 & $20: 40$ & $-15,70$ & $14: 20$ \\
\hline 3 & 100 & 72,11 & 73,11 & 0,99 & 13,37 & $1: 00$ & $-15,77$ & $13: 40$ \\
\hline 4 & 101 & 74,29 & 76,32 & 0,97 & 16,60 & $19: 40$ & $-17,82$ & $13: 20$ \\
\hline 5 & 102 & 74,00 & 75,07 & 0,99 & 14,80 & $19: 40$ & $-15,45$ & $10: 00$ \\
\hline 6 & 103 & 70,01 & 70,76 & 0,99 & 8,65 & $1: 00$ & $-13,13$ & 11:00 \\
\hline 7 & 104 & 73,04 & 73,39 & 1,00 & 12,76 & $20: 00$ & $-12,60$ & $10: 20$ \\
\hline 8 & 105 & 74,64 & 74,63 & 1,00 & 10,80 & $19: 20$ & $-11,94$ & $13: 20$ \\
\hline 9 & 106 & 74,33 & 75,94 & 0,98 & 12,10 & $19: 20$ & $-15,26$ & $12: 00$ \\
\hline 10 & 107 & 68,66 & 69,64 & 0,99 & 8,05 & $8: 00$ & $-9,85$ & $13: 40$ \\
\hline 11 & 108 & 75,11 & 77,37 & 0,97 & 10,38 & $20: 20$ & $-18,33$ & $12: 40$ \\
\hline 12 & 109 & 83,40 & 85,04 & 0,98 & 5,64 & $22: 20$ & $-13,88$ & $12: 40$ \\
\hline 13 & 110 & 81,93 & 83,05 & 0,99 & 5,83 & $7: 40$ & $-12,78$ & $11: 20$ \\
\hline 14 & 111 & 71,43 & 72,17 & 0,99 & 13,49 & $22: 40$ & $-11,05$ & $13: 00$ \\
\hline 15 & 112 & 72,38 & 71,92 & 1,01 & 15,73 & $21: 40$ & $-10,53$ & $13: 20$ \\
\hline 16 & 113 & 71,66 & 72,81 & 0,98 & 8,59 & $8: 00$ & $-10,08$ & $11: 20$ \\
\hline 17 & 114 & 74,79 & 75,17 & 0,99 & 14,18 & $21: 20$ & $-14,85$ & $12: 40$ \\
\hline 18 & 115 & 75,05 & 75,91 & 0,99 & 13,54 & $20: 40$ & $-16,05$ & $10: 00$ \\
\hline 19 & 116 & 71,16 & 71,61 & 0,99 & 17,04 & $20: 20$ & $-20,78$ & $12: 00$ \\
\hline 20 & 117 & 69,79 & 68,80 & 1,01 & 20,55 & $23: 00$ & $-16,27$ & $10: 40$ \\
\hline 21 & 118 & 71,28 & 70,39 & 1,01 & 15,65 & $24: 00$ & $-13,48$ & $10: 20$ \\
\hline 22 & 119 & 70,43 & 69,63 & 1,01 & 15,55 & $19: 20$ & $-13,99$ & $10: 40$ \\
\hline 23 & 120 & 71,24 & 71,56 & 1,00 & 10,24 & $19: 00$ & $-15,63$ & $10: 20$ \\
\hline 24 & 121 & 71,94 & 70,57 & 1,02 & 18,46 & $20: 20$ & $-15,08$ & $10: 20$ \\
\hline 25 & 122 & 73,62 & 73,99 & 0,99 & 10,21 & 19:00 & $-15,69$ & $10: 20$ \\
\hline 26 & 123 & 81,70 & 82,83 & 0,99 & 8,76 & $8: 00$ & $-25,05$ & $13: 00$ \\
\hline 27 & 124 & 77,40 & 78,47 & 0,99 & 7,00 & $8: 00$ & $-14,03$ & $13: 20$ \\
\hline 28 & 125 & 80,56 & 81,34 & 0,99 & 7,67 & $18: 40$ & $-13,66$ & $12: 20$ \\
\hline 29 & 126 & 75,10 & 74,18 & 1,01 & 15,55 & $22: 20$ & $-13,01$ & $11: 40$ \\
\hline 30 & 127 & 88,75 & 86,34 & 1,03 & 12,07 & $0: 20$ & $-8,73$ & $10: 20$ \\
\hline 31 & 128 & 77,93 & 74,31 & 1,05 & 19,15 & $9: 00$ & $-10,11$ & $15: 40$ \\
\hline
\end{tabular}

\section{$\begin{array}{llllll}\text { Média } & 74,74 & 75,11 & 1,00 & 12,55 & -14,48\end{array}$}

* Maior superávit entre os valores, médios de 20 minutos, obtidos no interior do ambiente protegido em comparação com os obtidos externamente;

** Maior déficit entre os valores, médios de 20 minutos, obtidos no interior do ambiente protegido em comparação com os obtidos externamente. 
Anexo 15 - Umidade relativa média diária (\%), no interior do ambiente protegido e na estação meteorológica, e maiores e menores diferenças ao longo do dia, no segundo cultivo da alface, em Piracicaba, SP, no ano de 2000.

\begin{tabular}{|c|c|c|c|c|c|c|c|c|}
\hline \multirow[t]{2}{*}{ DAT } & \multirow{2}{*}{$\begin{array}{c}\text { Dia } \\
\text { Juliano }\end{array}$} & \multicolumn{3}{|c|}{ Umidade Relativa média (\%) } & Diferença & \multicolumn{3}{|c|}{ (UR Amb. prot. - UF' Estaçăo) } \\
\hline & & Amb. prot. & Estação & Amb./prot. & Maior* & Horário & Menort* & Horário \\
\hline 1 & 176 & 63,27 & 62,27 & 1,02 & 25,80 & $8: 40$ & $-16,18$ & $16: 00$ \\
\hline 2 & 177 & 57,68 & 56,01 & 1,03 & 17,30 & $0: 00$ & $-8,00$ & $11: 40$ \\
\hline 3 & 178 & 65,11 & 64,05 & 1,02 & 13,83 & $19: 40$ & $-10,32$ & $13: 00$ \\
\hline 4 & 179 & 73,65 & 73,36 & 1,00 & 12,99 & $20: 20$ & $-11,12$ & $14: 00$ \\
\hline 5 & 180 & 67,34 & 66,88 & 1,01 & 14,88 & $23: 00$ & $-19,25$ & $10: 20$ \\
\hline 6 & 181 & 50,80 & 46,41 & 1,09 & 19,23 & 8:00 & $-6,25$ & $14: 20$ \\
\hline 7 & 182 & 76,23 & 76,39 & 1,00 & 10,20 & $2: 40$ & $-18,09$ & $15: 00$ \\
\hline 8 & 183 & 80,57 & 82,31 & 0,98 & 9,31 & $18: 40$ & $-19,67$ & $13: 40$ \\
\hline 9 & 184 & 70,65 & 69,77 & 1,01 & 13,89 & $19: 40$ & $-10,40$ & $12: 20$ \\
\hline 10 & 185 & 73,65 & 74,18 & 0,99 & 7,15 & $7: 40$ & $-10,45$ & $10: 20$ \\
\hline 11 & 186 & 73,05 & 75,50 & 0,97 & 3,77 & 23:00 & $-11,51$ & $15: 40$ \\
\hline 12 & 187 & 75,52 & 76,45 & 0,99 & 15,49 & $20: 20$ & $-17,95$ & $12: 40$ \\
\hline 13 & 188 & 71,39 & 72,23 & 0,99 & 7,27 & $1: 40$ & $-13,43$ & $11: 40$ \\
\hline 14 & 189 & 66,61 & 66,39 & 1,00 & 8,23 & $1: 00$ & $-9,90$ & $11: 40$ \\
\hline 15 & 190 & 67,68 & 66,06 & 1,02 & 11,57 & $1: 40$ & $-10,09$ & $13: 20$ \\
\hline 16 & 191 & 64,23 & 63,38 & 1,01 & 14,35 & $23: 00$ & $-9,64$ & $15: 00$ \\
\hline 17 & 192 & 62,89 & 59,36 & 1,06 & 25,98 & $22: 20$ & $-8,56$ & $15: 00$ \\
\hline 18 & 193 & 56,31 & 56,44 & 1,00 & 11,99 & $8: 40$ & $-9,50$ & $10: 40$ \\
\hline 19 & 194 & 70,72 & 72,55 & 0,97 & 3,52 & $23: 40$ & $-9,75$ & $12: 20$ \\
\hline 20 & 195 & 65,83 & 64,20 & 1,03 & 14,75 & $19: 40$ & $-20,81$ & $13: 00$ \\
\hline 21 & 196 & 73,89 & 73,76 & 1,00 & 12,95 & $1: 00$ & $-22,84$ & $12: 40$ \\
\hline 22 & 197 & 87,93 & 87,73 & 1,00 & 18,45 & $9: 00$ & $-16,77$ & $11: 40$ \\
\hline 23 & 198 & 70,68 & 69,92 & 1,01 & 5,98 & $3: 40$ & $-6,86$ & $13: 00$ \\
\hline 24 & 199 & 64,35 & 64,18 & 1,00 & 17,41 & $8: 40$ & $-21,77$ & $15: 20$ \\
\hline 25 & 200 & 73,72 & 72,09 & 1,02 & 13,18 & $19: 20$ & $-14,63$ & $12: 40$ \\
\hline 26 & 201 & 76,68 & 75,21 & 1,02 & 18,89 & 21:00 & $-13,00$ & $16: 20$ \\
\hline 27 & 202 & 68,36 & 67,32 & 1,02 & 17,84 & $20: 40$ & $-14,90$ & $10: 40$ \\
\hline 28 & 203 & 70,46 & 69,16 & 1,02 & 17,91 & $8: 40$ & $-15,16$ & $14: 40$ \\
\hline 29 & 204 & 69,43 & 69,15 & 1,00 & 11,71 & $1: 20$ & $-16,69$ & $12: 20$ \\
\hline 30 & 205 & 94,79 & 95,76 & 0,99 & 3,22 & $19: 40$ & $-9,65$ & $13: 00$ \\
\hline 31 & 206 & 81,55 & 82,39 & 0,99 & 15,53 & $20: 40$ & $-18,80$ & $12: 40$ \\
\hline 32 & 207 & 80,01 & 82,54 & 0,97 & 10,32 & $0: 00$ & $-21,34$ & $12: 20$ \\
\hline 33 & 208 & 82,82 & 85,94 & 0,96 & 13,82 & $20: 20$ & $-14,79$ & $13: 20$ \\
\hline 34 & 209 & 76,35 & 78,77 & 0,97 & 9,59 & $9: 00$ & $-20,92$ & $13: 00$ \\
\hline 35 & 210 & 76,21 & 78,14 & 0,98 & 15,17 & $22: 40$ & $-22,20$ & $13: 20$ \\
\hline
\end{tabular}


Anexo 15 - Umidade relativa média diária (\%), no interior do ambiente protegido e na estação meteorológica, e maiores e menores diferenças ao longo do dia, no segundo cultivo da alface, em Piracicaba, SP, no ano de 2000.

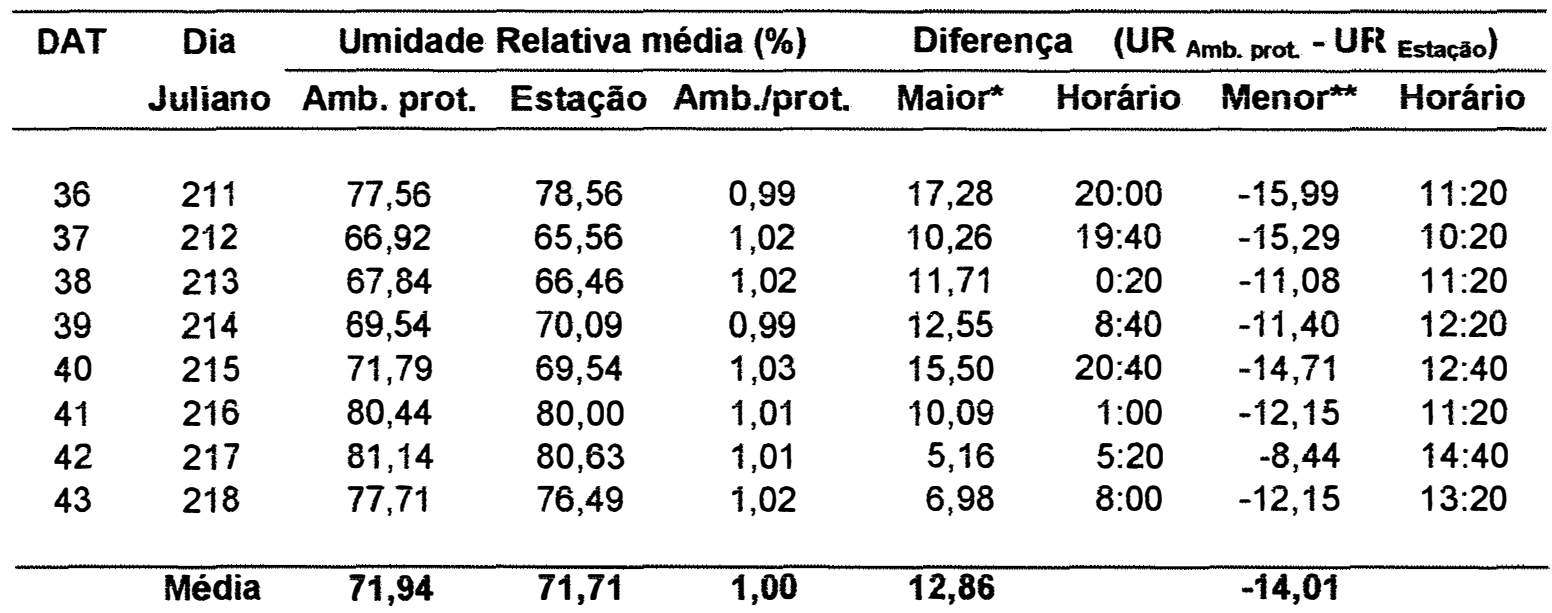

* Maior superávit entre os valores, médios de 20 minutos, obtidos no interior do ambiente protegido em comparação com os obtidos extemamente;

** Maior déficit entre os valores, médios de 20 minutos, obtidos no interior do ambiente protegido em comparação com os obtidos externamente. 
Anexo 16 - Velocidade média do vento $\left(\mathrm{m} . \mathrm{s}^{-1}\right)$, diária e diurna, no interior do ambiente protegido e na estação meteorológica, e máximas diárias, no primeiro cultivo da alface, em Piracicaba, SP, no ano de 2000.

\begin{tabular}{|c|c|c|c|c|c|c|c|c|}
\hline \multirow{3}{*}{ DAT } & \multirow{3}{*}{$\begin{array}{c}\text { Dia } \\
\text { Juliano }\end{array}$} & \multicolumn{7}{|c|}{ Velocidade do Vento $\left({\left.\mathrm{m} . \mathrm{s}^{-1}\right)}^{-1}\right.$} \\
\hline & & \multicolumn{2}{|c|}{ Média tiária } & \multicolumn{2}{|c|}{ Média cliurna } & \multicolumn{3}{|c|}{ Máxima diária } \\
\hline & & Amb. prot. & Estação & Amb. prot. & Estação & Amb. prot. & Estação & Horário \\
\hline 1 & 98 & 0,04 & 0,80 & 0,05 & 0,91 & 0,08 & 1,61 & $22: 40$ \\
\hline 2 & 99 & 0,04 & 0,80 & 0,04 & 0,70 & 0,11 & 2,11 & 21:00 \\
\hline 3 & 100 & 0,05 & 0,92 & 0,04 & 0,89 & 0,11 & 2,11 & 21:00 \\
\hline 4 & 101 & 0,05 & 0,98 & 0,06 & 1,16 & 0,13 & 2,54 & $11: 20$ \\
\hline 5 & 102 & 0,04 & 0,86 & 0,05 & 1,06 & 0,11 & 2,21 & $22: 00$ \\
\hline 6 & 103 & 0,05 & 1,09 & 0,07 & 1,36 & 0,12 & 2,46 & $14: 20$ \\
\hline 7 & 104 & 0,07 & 1,40 & 0,08 & 1,64 & 0,15 & 2,94 & $14: 00$ \\
\hline 8 & 105 & 0,04 & 0,80 & 0,05 & 0,98 & 0,15 & 2,99 & $23: 40$ \\
\hline 9 & 106 & 0,06 & 1,21 & 0,05 & 0,96 & 0,16 & 3,20 & $20: 20$ \\
\hline 10 & 107 & 0,07 & 1,39 & 0,07 & 1,44 & 0,16 & 3,28 & $9: 40$ \\
\hline 11 & 108 & 0,03 & 0,69 & 0,04 & 0,74 & 0,11 & 2,12 & $20: 40$ \\
\hline 12 & 109 & 0,03 & 0,68 & 0,04 & 0,80 & 0,09 & 1,88 & $14: 20$ \\
\hline 13 & 110 & 0,06 & 1,26 & 0,07 & 1,45 & 0,20 & 4,00 & $20: 00$ \\
\hline 14 & 111 & 0,09 & 1,83 & 0,11 & 2,23 & 0,19 & 3,86 & $15: 40$ \\
\hline 15 & 112 & 0,06 & 1,13 & 0,07 & 1,47 & 0,14 & 2,88 & $22: 20$ \\
\hline 16 & 113 & 0,08 & 1,70 & 0,07 & 1,42 & 0,19 & 3,86 & $13: 00$ \\
\hline 17 & 114 & 0,04 & 0,79 & 0,06 & 1,12 & 0,13 & 2,67 & $10: 00$ \\
\hline 18 & 115 & 0,05 & 1,02 & 0,05 & 1,04 & 0,13 & 2,54 & $23: 00$ \\
\hline 19 & 116 & 0,06 & 1,24 & 0,07 & 1,34 & 0,12 & 2,32 & $21: 20$ \\
\hline 20 & 117 & 0,07 & 1,33 & 0,07 & 1,46 & 0,13 & 2,63 & $10: 00$ \\
\hline 21 & 118 & 0,07 & 1,31 & 0,08 & 1,51 & 0,13 & 2,64 & $10: 00$ \\
\hline 22 & 119 & 0,08 & 1,56 & 0,07 & 1,48 & 0,16 & 3,10 & $12: 00$ \\
\hline 23 & 120 & 0,06 & 1,23 & 0,07 & 1,31 & 0,12 & 2,46 & $14: 20$ \\
\hline 24 & 121 & 0,05 & 0,92 & 0,05 & 1,08 & 0,11 & 2,20 & $14: 00$ \\
\hline 25 & 122 & 0,08 & 1,53 & 0,09 & 1,80 & 0,17 & 3,36 & $11: 40$ \\
\hline 26 & 123 & 0,09 & 1,90 & 0,10 & 1,95 & 0,19 & 3,71 & $10: 00$ \\
\hline 27 & 124 & 0,07 & 1,45 & 0,08 & 1,62 & 0,15 & 3,04 & $21: 20$ \\
\hline 28 & 125 & 0,07 & 1,31 & 0,08 & 1,50 & 0,15 & 3,02 & $10: 20$ \\
\hline 29 & 126 & 0,08 & 1,63 & 0,10 & 1,91 & 0,17 & 3,47 & $10: 00$ \\
\hline 30 & 127 & 0,07 & 1,44 & 0,09 & 1,83 & 0,22 & 4,34 & $12: 20$ \\
\hline 31 & 128 & 0,04 & 0,86 & 0,04 & 0,89 & 0,10 & 2,03 & $23: 40$ \\
\hline
\end{tabular}


Anexo 17 - Velocidade média do vento $\left(\mathrm{m}_{\mathrm{s}} \mathrm{s}^{-1}\right)$, diária e diurna, no interior do ambiente protegido e na estação meteorológica, e máximas diárias, ao longo do segundo cultivo da alface, em Piracicaba, SP, no ano de 2000.

\begin{tabular}{|c|c|c|c|c|c|c|c|c|}
\hline \multirow{3}{*}{ DAT } & \multirow{3}{*}{$\begin{array}{c}\text { Dia } \\
\text { Juliano }\end{array}$} & \multicolumn{7}{|c|}{ Velocidade do Vento $\left(\mathrm{m} . \mathrm{s}^{-1}\right)$} \\
\hline & & \multicolumn{2}{|c|}{ Média dliária } & \multicolumn{2}{|c|}{ Média diurna } & \multicolumn{3}{|c|}{ Máxima diária } \\
\hline & & Amb. prot. & Estação & Amb. prot. & Estação & Amb. prot. & Estação & Horário \\
\hline 1 & 176 & 0,14 & 2,74 & 0,17 & 3,45 & 0,29 & 5,79 & $11: 00$ \\
\hline 2 & 177 & 0,10 & 2,02 & 0,10 & 1,93 & 0,21 & 4,22 & $2: 20$ \\
\hline 3 & 178 & 0,09 & 1,73 & 0,10 & 1,93 & 0,17 & 3,41 & 7:00 \\
\hline 4 & 179 & 0,06 & 1,22 & 0,06 & 1,14 & 0,17 & 3,42 & $10: 00$ \\
\hline 5 & 180 & 0,08 & 1,59 & 0,12 & 2,36 & 0,24 & 4,89 & $13: 20$ \\
\hline 6 & 181 & 0,10 & 1,97 & 0,12 & 2,33 & 0,20 & 4,09 & $13: 20$ \\
\hline 7 & 182 & 0,08 & 1,68 & 0,07 & 1,38 & 0,23 & 4,50 & $7: 40$ \\
\hline 8 & 183 & 0,06 & 1,10 & 0,05 & 1,02 & 0,11 & 2,19 & $23: 20$ \\
\hline 9 & 184 & 0,09 & 1,72 & 0,10 & 2,09 & 0,16 & 3,13 & $16: 20$ \\
\hline 10 & 185 & 0,11 & 2,12 & 0,12 & 2,38 & 0,22 & 4,32 & $17: 00$ \\
\hline 11 & 186 & 0,09 & 1,75 & 0,11 & 2,21 & 0,18 & 3,57 & $10: 40$ \\
\hline 12 & 187 & 0,03 & 0,63 & 0,03 & 0,67 & 0,11 & 2,16 & $22: 00$ \\
\hline 13 & 188 & 0,08 & 1,63 & 0,09 & 1,85 & 0,15 & 3,09 & $13: 20$ \\
\hline 14 & 189 & 0,10 & 1,91 & 0,11 & 2,20 & 0,21 & 4,14 & $12: 20$ \\
\hline 15 & 190 & 0,09 & 1,86 & 0,11 & 2,17 & 0,19 & 3,89 & $11: 40$ \\
\hline 16 & 191 & 0,10 & 1,96 & 0,11 & 2,13 & 0,15 & 2,92 & $12: 40$ \\
\hline 17 & 192 & 0,10 & 2,08 & 0,13 & 2,64 & 0,20 & 4,03 & $12: 20$ \\
\hline 18 & 193 & 0,09 & 1,85 & 0,10 & 2,09 & 0,17 & 3,46 & $13: 40$ \\
\hline 19 & 194 & 0,07 & 1,46 & 0,08 & 1,67 & 0,12 & 2,45 & $13: 00$ \\
\hline 20 & 195 & 0,03 & 0,69 & 0,05 & 0,96 & 0,08 & 1,66 & $10: 40$ \\
\hline 21 & 196 & 0,05 & 1,05 & 0,06 & 1,22 & 0,13 & 2,59 & $18: 40$ \\
\hline 22 & 197 & 0,06 & 1,21 & 0,08 & 1,56 & 0,16 & 3,19 & 4:00 \\
\hline 23 & 198 & 0,12 & 2,47 & 0,17 & 3,32 & 0,22 & 4,42 & $15: 20$ \\
\hline 24 & 199 & 0,05 & 0,98 & 0,05 & 0,98 & 0,10 & 1,93 & $22: 20$ \\
\hline 25 & 200 & 0,06 & 1,25 & 0,06 & 1,25 & 0,13 & 2,64 & $10: 00$ \\
\hline 26 & 201 & 0,07 & 1,48 & 0,08 & 1,69 & 0,17 & 3,48 & $9: 00$ \\
\hline 27 & 202 & 0,05 & 0,92 & 0,04 & 0,72 & 0,12 & 2,41 & $21: 40$ \\
\hline 28 & 203 & 0,06 & 1,24 & 0,06 & 1,16 & 0,12 & 2,31 & $0: 00$ \\
\hline 29 & 204 & 0,11 & 2,17 & 0,12 & 2,47 & 0,21 & 4,16 & $14: 00$ \\
\hline 30 & 205 & 0,07 & 1,42 & 0,08 & 1,66 & 0,17 & 3,48 & $15: 00$ \\
\hline 31 & 206 & 0,04 & 0,88 & 0,05 & 1,01 & 0,10 & 2,01 & $15: 40$ \\
\hline 32 & 207 & 0,04 & 0,71 & 0,03 & 0,65 & 0,10 & 2,00 & $21: 40$ \\
\hline 33 & 208 & 0,04 & 0,79 & 0,05 & 0,90 & 0,12 & 2,30 & $20: 40$ \\
\hline 34 & 209 & 0,08 & 1,52 & 0,08 & 1,67 & 0,20 & 3,97 & $19: 00$ \\
\hline 35 & 210 & 0,04 & 0,75 & 0,04 & 0,79 & 0,12 & 2,46 & $21: 40$ \\
\hline
\end{tabular}


Anexo 17 - Velocidade média do vento $\left(\mathrm{m} . \mathrm{s}^{-1}\right)$, diária e diurna, no interior do ambiente protegido e na estação meteorológica, e máximas diárias, ao longo do segundo cultivo da alface, em Piracicaba, SP, no ano de 2000.

\begin{tabular}{|c|c|c|c|c|c|c|c|c|}
\hline \multirow{3}{*}{ DAT } & \multirow{3}{*}{$\begin{array}{c}\text { Dia } \\
\text { Juliano }\end{array}$} & \multicolumn{7}{|c|}{ Velocidade do Vento $\left(\mathrm{m} \cdot \mathrm{s}^{-1}\right)$} \\
\hline & & \multicolumn{2}{|c|}{ Média diária } & \multicolumn{2}{|c|}{ Média diurna } & \multicolumn{3}{|c|}{ Máxima } \\
\hline & & Amb. prot. & Estação & Amb. prot. & Estação & Amb. prot. & Estação & Horário \\
\hline 36 & 211 & 0,04 & 0,74 & 0,03 & 0,62 & 0,12 & 2,48 & $13: 20$ \\
\hline 37 & 212 & 0,09 & 1,88 & 0,10 & 1,92 & 0,16 & 3,22 & $11: 20$ \\
\hline 38 & 213 & 0,08 & 1,62 & 0,07 & 1,48 & 0,19 & 3,87 & $20: 20$ \\
\hline 39 & 214 & 0,04 & 0,75 & 0,04 & 0,73 & 0,09 & 1,89 & $16: 20$ \\
\hline 40 & 215 & 0,09 & 1,73 & 0,12 & 2,35 & 0,22 & 4,35 & $12: 20$ \\
\hline 41 & 216 & 0,07 & 1,33 & 0,08 & 1,64 & 0,12 & 2,50 & $8: 00$ \\
\hline 42 & 217 & 0,16 & 3,20 & 0,20 & 3,96 & 0,31 & 6,19 & $15: 20$ \\
\hline 43 & 218 & 0,09 & 1,72 & 0,09 & 1,88 & 0,17 & 3,38 & $0: 00$ \\
\hline & Média & $\overline{0,08}$ & 1,52 & 0,09 & 1,73 & 0,17 & 3,32 & \\
\hline
\end{tabular}


Anexo 18 - Evapotranspiração de referência $\left(E T o\right.$, em $\mathrm{mm} \cdot$ dia $\left.^{-1}\right)$ estimada, pela equação de Penman-Monteith, com dados obtidos na estação meteorológica e no interior do ambiente protegido, e respectivas contribuições diabáticas e adiabáticas, no primeiro cultivo da alface, em Piracicaba, SP, no ano de 2000.

\begin{tabular}{|c|c|c|c|c|c|c|c|}
\hline \multirow[t]{2}{*}{ DAT } & \multirow{2}{*}{$\begin{array}{c}\text { Dia } \\
\text { Juliano }\end{array}$} & \multicolumn{3}{|c|}{ ETo Estação (mm.dia $\left.{ }^{-1}\right)$} & \multicolumn{3}{|c|}{ ETo Amb. protegido (mm.dia $\left.{ }^{-1}\right)$} \\
\hline & & Diabática & Adiabática & Total & Diabática & Adiabática & Total \\
\hline 1 & 98 & 3,40 & 0,62 & 4,02 & 3,54 & 0,04 & 3,58 \\
\hline 2 & 99 & 3,35 & 0,75 & 4,09 & 3,22 & 0,04 & 3,26 \\
\hline 3 & 100 & 3,57 & 0,84 & 4,42 & 3,57 & 0,05 & 3,63 \\
\hline 4 & 101 & 3,62 & 0,88 & 4,49 & 3,57 & 0,06 & 3,63 \\
\hline 5 & 102 & 3,44 & 0,89 & 4,33 & 3,45 & 0,06 & 3,51 \\
\hline 6 & 103 & 3,86 & 1,27 & 5,13 & 3,62 & 0,08 & 3,70 \\
\hline 7 & 104 & 3,46 & 1,32 & 4,78 & 3,18 & 0,08 & 3,26 \\
\hline 8 & 105 & 3,92 & 0,80 & 4,72 & 3,44 & 0,05 & 3,49 \\
\hline 9 & 106 & 3,66 & 0,95 & 4,61 & 3,36 & 0,06 & 3,42 \\
\hline 10 & 107 & 3,37 & 1,39 & 4,76 & 3,15 & 0,09 & 3,23 \\
\hline 11 & 108 & 3,22 & 0,52 & 3,73 & 2,97 & 0,04 & 3,00 \\
\hline 12 & 109 & 1,80 & 0,36 & 2,16 & 1,64 & 0,02 & 1,67 \\
\hline 13 & 110 & 2,30 & 0,86 & 3,16 & 2,03 & 0,06 & 2,09 \\
\hline 14 & 111 & 3,25 & 1,59 & 4,84 & 3,04 & 0,11 & 3,15 \\
\hline 15 & 112 & 3,21 & 1,07 & 4,28 & 2,98 & 0,07 & 3,05 \\
\hline 16 & 113 & 2,53 & 1,55 & 4,08 & 2,39 & 0,11 & 2,50 \\
\hline 17 & 114 & 3,29 & 0,74 & 4,03 & 3,04 & 0,06 & 3,10 \\
\hline 18 & 115 & 3,27 & 0,75 & 4,02 & 2,93 & 0,05 & 2,98 \\
\hline 19 & 116 & 3,61 & 1,17 & 4,77 & 3,01 & 0,08 & 3,09 \\
\hline 20 & 117 & 3,11 & 1,15 & 4,26 & 2,78 & 0,07 & 2,85 \\
\hline 21 & 118 & 3,06 & 1,18 & 4,24 & 2,81 & 0,08 & 2,89 \\
\hline 22 & 119 & 3,18 & 1,34 & 4,52 & 2,90 & 0,08 & 2,98 \\
\hline 23 & 120 & 3,26 & 1,11 & 4,37 & 2,83 & 0,07 & 2,90 \\
\hline 24 & 121 & 3,04 & 0,93 & 3,97 & 2,53 & 0,06 & 2,59 \\
\hline 25 & 122 & 3,02 & 1,37 & 4,38 & 2,60 & 0,09 & 2,69 \\
\hline 26 & 123 & 2,90 & 0,99 & 3,88 & 2,19 & 0,07 & 2,26 \\
\hline 27 & 124 & 2,87 & 0,97 & 3,84 & 2,33 & 0,07 & 2,39 \\
\hline 28 & 125 & 2,86 & 0,89 & 3,75 & 2,30 & 0,06 & 2,36 \\
\hline 29 & 126 & 2,66 & 1,18 & 3,84 & 2,33 & 0,07 & 2,41 \\
\hline 30 & 127 & 1,31 & 0,65 & 1,96 & 1,02 & 0,04 & 1,06 \\
\hline 31 & 128 & 2,29 & 0,69 & 2,98 & 1,97 & 0,04 & 2,01 \\
\hline & $\begin{array}{l}\text { Média } \\
\text { Total }\end{array}$ & $\begin{array}{r}3,09 \\
95,67\end{array}$ & $\begin{array}{r}0,99 \\
30,73\end{array}$ & $\begin{array}{r}4,08 \\
126,40\end{array}$ & $\begin{array}{r}2,80 \\
86,71\end{array}$ & $\begin{array}{l}0,06 \\
2,00\end{array}$ & $\begin{array}{r}2,86 \\
88,71\end{array}$ \\
\hline
\end{tabular}


Anexo 19 - Evapotranspiração de referência $\left(E T o\right.$, em $\left.\mathrm{mm} \cdot \mathrm{dia}^{-1}\right)$ estimada, pela equação de Penman-Monteith, com dados obtidos na estação meteorológica e no interior do ambiente protegido, e respectivas contribuições diabáticas e adiabáticas, no segundo cultivo da alface, em Piracicaba, SP, no ano de 2000.

\begin{tabular}{|c|c|c|c|c|c|c|c|}
\hline \multirow[t]{2}{*}{ DAT } & \multirow{2}{*}{$\begin{array}{c}\text { Dia } \\
\text { Juliano }\end{array}$} & \multicolumn{3}{|c|}{ ETo Estação (mm.dia $\left.{ }^{-1}\right)$} & \multicolumn{3}{|c|}{ ETo Amb. protegido (mm.dia $\left.{ }^{-1}\right)$} \\
\hline & & Diabática & Adiabática & Total & Diabática & Adiabática & Total \\
\hline 1 & 176 & 2,04 & 2,53 & 4,58 & 2,34 & 0,17 & 2,51 \\
\hline 2 & 177 & 2,62 & 2,38 & 5,00 & 2,63 & 0,14 & 2,77 \\
\hline 3 & 178 & 2,20 & 1,50 & 3,70 & 2,19 & 0,09 & 2,28 \\
\hline 4 & 179 & 1,35 & 0,82 & 2,17 & 1,24 & 0,05 & 1,28 \\
\hline 5 & 180 & 2,23 & 2,18 & 4,41 & 2,39 & 0,15 & 2,54 \\
\hline 6 & 181 & 1,91 & 2,99 & 4,90 & 1,86 & 0,17 & 2,04 \\
\hline 7 & 182 & 0,98 & 1,02 & 2,00 & 0,95 & 0,06 & 1,01 \\
\hline 8 & 183 & 2,36 & 0,53 & 2,89 & 2,51 & 0,04 & 2,55 \\
\hline 9 & 184 & 2,47 & 1,54 & 4,01 & 2,63 & 0,10 & 2,73 \\
\hline 10 & 185 & 1,69 & 1,53 & 3,22 & 1,70 & 0,11 & 1,80 \\
\hline 11 & 186 & 1,73 & 1,17 & 2,91 & 1,85 & 0,08 & 1,94 \\
\hline 12 & 187 & 2,26 & 0,52 & 2,77 & 2,32 & 0,03 & 2,35 \\
\hline 13 & 188 & 2,16 & 1,44 & 3,60 & 2,31 & 0,10 & 2,41 \\
\hline 14 & 189 & 2,07 & 1,81 & 3,89 & 2,25 & 0,12 & 2,37 \\
\hline 15 & 190 & 1,90 & 1,62 & 3,52 & 1,90 & 0,10 & 2,00 \\
\hline 16 & 191 & 2,51 & 1,97 & 4,48 & 2,54 & 0,12 & 2,66 \\
\hline 17 & 192 & 2,40 & 2,42 & 4,82 & 2,49 & 0,15 & 2,64 \\
\hline 18 & 193 & 1,97 & 2,31 & 4,28 & 1,90 & 0,14 & 2,04 \\
\hline 19 & 194 & 0,93 & 0,94 & 1,87 & 0,71 & 0,06 & 0,77 \\
\hline 20 & 195 & 2,03 & 0,61 & 2,64 & 1,91 & 0,04 & 1,95 \\
\hline 21 & 196 & 2,16 & 0,89 & 3,05 & 2,17 & 0,06 & 2,23 \\
\hline 22 & 197 & 0,96 & 0,57 & 1,54 & 0,84 & 0,04 & 0,88 \\
\hline 23 & 198 & 1,90 & 1,67 & 3,57 & 1,98 & 0,12 & 2,10 \\
\hline 24 & 199 & 1,95 & 0,71 & 2,67 & 1,55 & 0,04 & 1,60 \\
\hline 25 & 200 & 1,64 & 0,61 & 2,26 & 1,61 & 0,04 & 1,65 \\
\hline 26 & 201 & 0,82 & 0,65 & 1,47 & 0,69 & 0,04 & 0,73 \\
\hline 27 & 202 & 1,51 & 0,63 & 2,14 & 1,42 & 0,04 & 1,46 \\
\hline 28 & 203 & 2,30 & 0,71 & 3,01 & 2,28 & 0,04 & 2,32 \\
\hline 29 & 204 & 1,57 & 1,73 & 3,30 & 1,59 & 0,11 & 1,70 \\
\hline 30 & 205 & 0,29 & 0,12 & 0,41 & 0,23 & 0,01 & 0,24 \\
\hline 31 & 206 & 1,85 & 0,41 & 2,26 & 1,61 & 0,03 & 1,64 \\
\hline 32 & 207 & 2,18 & 0,38 & 2,55 & 1,86 & 0,03 & 1,89 \\
\hline 33 & 208 & 2,29 & 0,42 & 2,71 & 1,76 & 0,02 & 1,78 \\
\hline 34 & 209 & 2,50 & 1,13 & 3,62 & 2,24 & 0,09 & 2,32 \\
\hline 35 & 210 & 2,65 & 0,54 & 3,19 & 2,16 & 0,04 & 2,20 \\
\hline
\end{tabular}


Anexo 19 - Evapotranspiração de referência $\left(E T o\right.$, em $m$ mma $\left.^{-1}\right)$ estimada, pela equação de Penman-Monteith, com dados obtidos na estação meteorológica e no interior do ambiente protegido, e respectivas contribuições diabáticas e adiabáticas, no segundo cultivo da alface, em Piracicaba, SP, no ano de 2000.

\begin{tabular}{|c|c|c|c|c|c|c|c|}
\hline \multirow[t]{2}{*}{ DAT } & \multirow{2}{*}{$\begin{array}{c}\text { Dia } \\
\text { Juliano }\end{array}$} & \multicolumn{3}{|c|}{ ETo Estação (mm.dia $\left.{ }^{-1}\right)$} & \multicolumn{3}{|c|}{ ETo Amt. protegido $\left(\mathrm{mm} \mathrm{dia}^{-1}\right)$} \\
\hline & & Diabática & Adiabática & Total & Diabática & Adiabática & Total \\
\hline 36 & 211 & 2,28 & 0,47 & 2,75 & 1,88 & 0,03 & 1,90 \\
\hline 37 & 212 & 2,63 & 1,44 & 4,07 & 2,31 & 0,08 & 2,39 \\
\hline 38 & 213 & 2,09 & 1,34 & 3,43 & 2,08 & 0,08 & 2,16 \\
\hline 39 & 214 & 2,08 & 0,65 & 2,73 & 1,48 & 0,04 & 1,52 \\
\hline 40 & 215 & 1,54 & 1,18 & 2,71 & 1,53 & 0,10 & 1,63 \\
\hline 41 & 216 & 1,39 & 0,74 & 2,13 & 0,90 & 0,04 & 0,95 \\
\hline 42 & 217 & 1,68 & 1,46 & 3,14 & 1,61 & 0,12 & 1,73 \\
\hline 43 & 218 & 1,78 & 1,58 & 3,37 & 1,79 & 0,12 & 1,91 \\
\hline & $\begin{array}{l}\text { Média } \\
\text { Total }\end{array}$ & $\begin{array}{r}1,90 \\
81,85\end{array}$ & $\begin{array}{r}1,21 \\
51,87\end{array}$ & $\begin{array}{r}3,11 \\
133,72\end{array}$ & $\begin{array}{r}1,82 \\
78,21\end{array}$ & $\begin{array}{l}0,08 \\
3,36\end{array}$ & $\begin{array}{r}1,90 \\
81,57\end{array}$ \\
\hline
\end{tabular}


Anexo 20 - Gradientes, térmico $\left({ }^{\circ} \mathrm{C}\right)$ e de pressão parcial do vapor $(\mathrm{kPa})$, razão de Bowen e saldo de radiação ( $\mathrm{Rn}$, em W. $\mathrm{m}^{-2}$ ), aos $16 \mathrm{DAT}$, no primeiro cultivo da alface, em Piracicaba, SP, no ano de 2000

\begin{tabular}{|c|c|c|c|c|c|c|c|c|}
\hline \multirow[t]{2}{*}{ Horário } & \multicolumn{3}{|c|}{ Temperatura do ar $\left({ }^{\circ} \mathrm{C}\right)$} & \multicolumn{3}{|c|}{ Pressão parcial do vapor (kPa) } & \multirow{2}{*}{$\begin{array}{c}\text { Razão de } \\
\text { Bowen }\end{array}$} & \multirow{2}{*}{$\begin{array}{c}R n \\
\left(W \cdot m^{-2}\right)\end{array}$} \\
\hline & $1,25 \mathrm{~m}$ & $0,25 \mathrm{~m}$ & $\Delta T$ & $1,25 \mathrm{~m}$ & $0,25 \mathrm{~m}$ & $\Delta$ ea & & \\
\hline $6: 00$ & 11,22 & 11,19 & $-0,032$ & 1,259 & 1,257 & $-0,002$ & 1,002 & $-16,13$ \\
\hline $6: 20$ & 11,19 & 11,17 & $-0,022$ & 1,281 & 1,277 & $-0,004$ & 0,344 & $-15,57$ \\
\hline $6: 40$ & 11,00 & 10,97 & $-0,031$ & 1,271 & 1,268 & $-0,003$ & 0,647 & $-13,09$ \\
\hline 7:00 & 11,31 & $\uparrow 1,29$ & $-0,022$ & 1,351 & 1,348 & $-0,003$ & 0,459 & $-4,58$ \\
\hline $7: 20$ & 12,15 & 12,13 & $-0,023$ & 1,356 & 1,353 & $-0,003$ & 0,480 & 11,59 \\
\hline $7: 40$ & 13,34 & 13,32 & $-0,023$ & 1,390 & 1,388 & $-0,002$ & 0,720 & 39,86 \\
\hline $8: 00$ & 14,58 & 14,61 & 0,031 & 1,381 & 1,383 & 0,002 & 0,970 & 126,04 \\
\hline $8: 20$ & 16,07 & 16,10 & 0,035 & 1,413 & 1,404 & $-0,009$ & $-0,243$ & 82,77 \\
\hline $8: 40$ & 17,74 & 17,82 & 0,077 & 1,432 & 1,420 & $-0,012$ & $-0,402$ & 114,28 \\
\hline $9: 00$ & 18,78 & 18,85 & 0,064 & 1,440 & 1,424 & $-0,016$ & $-0,250$ & 165,04 \\
\hline $9: 20$ & 20,19 & 20,29 & 0,106 & 1,445 & 1,428 & $-0,017$ & $-0,390$ & 234,24 \\
\hline $9: 40$ & 21,36 & 21,40 & 0,040 & 1,451 & 1,439 & $-0,012$ & $-0,209$ & 266,86 \\
\hline $10: 00$ & 22,14 & 22,16 & 0,017 & 1,461 & 1,459 & $-0,002$ & $-0,532$ & 314,99 \\
\hline $10: 20$ & 22,87 & 22,89 & 0,023 & 1,543 & 1,539 & $-0,004$ & $-0,360$ & 319,55 \\
\hline $10: 40$ & 22,92 & 22,88 & $-0,033$ & 1,618 & 1,611 & $-0,007$ & 0,295 & 277,30 \\
\hline $11: 00$ & 23,52 & 23,66 & 0,137 & 1,662 & 1,672 & 0,010 & 0,858 & 254,71 \\
\hline $11: 20$ & 23,05 & 23,08 & 0,031 & 1,701 & 1,696 & $-0,005$ & $-0,388$ & 210,03 \\
\hline $11: 40$ & 24,46 & 24,5 & 0,042 & 1,762 & 1,749 & $-0,013$ & $-0,202$ & 274,36 \\
\hline $12: 00$ & 24,52 & 24,28 & $-0,240$ & 1,812 & 1,796 & $-0,016$ & 0,939 & 361,80 \\
\hline $12: 20$ & 24,62 & 24,59 & $-0,030$ & 1,844 & 1,840 & $-0,004$ & 0,469 & 335,25 \\
\hline $12: 40$ & 25,64 & 25,67 & 0,026 & 1,870 & 1,872 & 0,002 & 0,814 & 173,25 \\
\hline $13: 00$ & 26,17 & 26,07 & $-0,099$ & 1,856 & 1,846 & $-0,010$ & 0,620 & 424,82 \\
\hline $13: 20$ & 25,34 & 25,29 & $-0,047$ & 1,940 & 1,949 & 0,009 & $-0,327$ & 274,97 \\
\hline $13: 40$ & 26,04 & 26,14 & 0,108 & 2,015 & 2,023 & 0,008 & 0,845 & 339,00 \\
\hline $14: 00$ & 25,62 & 25,73 & 0,113 & 2,018 & 2,028 & 0,010 & 0,707 & 309,42 \\
\hline $14: 20$ & 26,34 & 26,32 & $-0,022$ & 2,072 & 2,066 & $-0,006$ & 0,229 & 304,86 \\
\hline $14: 40$ & 26,88 & 26,91 & 0,034 & 2,119 & 2,108 & $-0,011$ & $-0,192$ & 372,94 \\
\hline $15: 00$ & 26,2 & 26,19 & $-0,009$ & 2,165 & 2,162 & $-0,003$ & 0,188 & 278,92 \\
\hline $15: 20$ & 26,53 & 26,53 & $-0,002$ & 2,155 & 2,154 & $-0,001$ & 0,125 & 287,23 \\
\hline $15: 40$ & 25,43 & 25,29 & $-0,135$ & 2,124 & 2,111 & $-0,013$ & 0,650 & 117,93 \\
\hline $16: 00$ & 25,69 & 25,63 & $-0,068$ & 2,067 & 2,062 & $-0,005$ & 0,851 & 152,88 \\
\hline $16: 20$ & 26,27 & 26,08 & $-0,208$ & 2,018 & 2,011 & $-0,007$ & 1,860 & 152,68 \\
\hline $16: 40$ & 25,48 & 25,28 & $-0,199$ & 1,973 & 1,963 & $-0,010$ & 1,246 & 82,37 \\
\hline $17: 00$ & 24,84 & 24,63 & $-0,211$ & 1,891 & 1,878 & $-0,013$ & 1,016 & 36,56 \\
\hline $17: 20$ & 24,51 & 24,34 & $-0,170$ & 1,800 & 1,790 & $-0,010$ & 1,064 & 24,09 \\
\hline $17: 40$ & 23,65 & 23,63 & $-0,023$ & 1,644 & 1,653 & 0,009 & $-0,160$ & $-3,28$ \\
\hline $18: 00$ & 22,86 & 22,88 & 0,023 & 1,511 & 1,516 & 0,005 & 0,288 & $-21,92$ \\
\hline
\end{tabular}


Anexo 21 - Gradientes, térmico $\left({ }^{\circ} \mathrm{C}\right)$ e de pressão parcial do vapor $(\mathrm{kPa})$, razão de Bowen e saldo de radiação $\left(\mathrm{Rn}, \mathrm{em} \mathrm{W} \cdot \mathrm{m}^{-2}\right)$, aos $22 \mathrm{DAT}$, no segundo cultivo da alface, em Piracicaba, SP, no ano de 2000.

\begin{tabular}{|c|c|c|c|c|c|c|c|c|}
\hline \multirow[t]{2}{*}{ Horário } & \multicolumn{3}{|c|}{ Temperatura do ar $\left({ }^{\circ} \mathrm{C}\right)$} & \multicolumn{3}{|c|}{ Pressão parcial do vapor (kPa) } & \multirow{2}{*}{$\begin{array}{c}\text { Razão de } \\
\text { Bowen }\end{array}$} & \multirow{2}{*}{$\begin{array}{c}\text { Rn } \\
\left(W \cdot m^{-2}\right) \\
\end{array}$} \\
\hline & $1,25 \mathrm{~m}$ & $0,25 \mathrm{~m}$ & $\Delta \mathrm{T}$ & $1,25 \mathrm{~m}$ & $0,25 \mathrm{~m}$ & $\Delta$ ea & & \\
\hline 6:00 & 9,96 & 9,98 & 0,017 & 0,783 & 0,786 & 0,003 & 0,355 & $-13,72$ \\
\hline $6: 20$ & 9,79 & 9,8 & 0,012 & 0,784 & 0,786 & 0,002 & 0,376 & $-14,20$ \\
\hline $6: 40$ & 9,71 & 9,74 & 0,033 & 0,781 & 0,783 & 0,002 & 1,033 & $-14,23$ \\
\hline 7:00 & 9,48 & 9,51 & 0,029 & 0,774 & 0,777 & 0,003 & 0,605 & $-13,21$ \\
\hline $7: 20$ & 9,94 & 9,95 & 0,011 & 0,773 & 0,775 & 0,002 & 0,344 & $-5,58$ \\
\hline $7: 40$ & 10,68 & 10,71 & 0,027 & 0,786 & 0,789 & 0,003 & 0,563 & 4,38 \\
\hline $8: 00$ & 11,63 & 11,63 & 0,004 & 0,809 & 0,810 & 0,001 & 0,250 & 21,08 \\
\hline $8: 20$ & 13,46 & 13,43 & $-0,023$ & 0,846 & 0,844 & $-0,002$ & 0,720 & 67,51 \\
\hline $8: 40$ & 16,18 & 16,16 & $-0,022$ & 0,904 & 0,901 & $-0,003$ & 0,459 & 74,70 \\
\hline $9: 00$ & 19,34 & 19,31 & $-0,027$ & 0,966 & 0,980 & 0,014 & $-0,121$ & 122,00 \\
\hline $9: 20$ & 21,13 & 21,08 & $-0,055$ & 1,131 & 1,123 & $-0,008$ & 0,430 & 141,50 \\
\hline $9: 40$ & 21,27 & 21,29 & 0,021 & 1,243 & 1,231 & $-0,012$ & $-0,110$ & 101,60 \\
\hline $10: 00$ & 21,57 & 21,59 & 0,023 & 1,281 & 1,268 & $-0,013$ & $-0,111$ & 92,60 \\
\hline $10: 20$ & 22,53 & 22,56 & 0,032 & 1,323 & 1,314 & $-0,009$ & $-0,223$ & 108,60 \\
\hline $10: 40$ & 22,91 & 22,92 & 0,009 & 1,370 & 1,359 & $-0,011$ & $-0,051$ & 116,70 \\
\hline $11: 00$ & 25,54 & 25,55 & 0,011 & 1,546 & 1,526 & $-0,020$ & $-0,034$ & 237,90 \\
\hline $11: 20$ & 28,43 & 28,39 & $-0,043$ & 1,754 & 1,742 & $-0,012$ & 0,224 & 314,80 \\
\hline $11: 40$ & 26,77 & 26,68 & $-0,091$ & 1,864 & 1,847 & $-0,017$ & 0,335 & 160,70 \\
\hline $12: 00$ & 26,45 & 26,34 & $-0,110$ & 1,875 & 1,860 & $-0,015$ & 0,459 & 134,40 \\
\hline $12: 20$ & 25,97 & 25,88 & $-0,091$ & 1,836 & 1,823 & $-0,013$ & 0,438 & 117,60 \\
\hline $12: 40$ & 24,07 & 23,89 & $-0,185$ & 1,794 & 1,776 & $-0,018$ & 0,643 & 91,80 \\
\hline $13: 00$ & 21,22 & 20,97 & $-0,252$ & 1,676 & 1,659 & $-0,017$ & 0,928 & 63,37 \\
\hline $13: 20$ & 20,56 & 20,34 & $-0,224$ & 1,546 & 1,527 & $-0,019$ & 0,738 & 56,77 \\
\hline $13: 40$ & 20,41 & 20,2 & $-0,207$ & 1,484 & 1,473 & $-0,011$ & 1,178 & 44,32 \\
\hline $14: 00$ & 20,1 & 19,87 & $-0,236$ & 1,441 & 1,432 & $-0,009$ & 1,641 & 68,35 \\
\hline $14: 20$ & 19,29 & 19,12 & $-0,169$ & 1,412 & 1,403 & $-0,009$ & 1,175 & 45,65 \\
\hline $14: 40$ & 18,46 & 18,36 & $-0,107$ & 1,370 & 1,356 & $-0,014$ & 0,478 & 7,29 \\
\hline $15: 00$ & 17,25 & 17,2 & $-0,049$ & 1,299 & 1,289 & $-0,010$ & 0,307 & 7,93 \\
\hline $15: 20$ & 17,1 & 17,08 & $-0,026$ & 1,272 & 1,261 & $-0,011$ & 0,148 & 5,29 \\
\hline $15: 40$ & 17,1 & 17,06 & $-0,039$ & 1,261 & 1,252 & $-0,009$ & 0,271 & 10,85 \\
\hline $16: 00$ & 17,14 & 17,13 & $-0,014$ & 1,253 & 1,248 & $-0,005$ & 0,175 & 16,11 \\
\hline $16: 20$ & 17,03 & 17,05 & 0,015 & 1,246 & 1,241 & $-0,005$ & $-0,188$ & 6,46 \\
\hline $16: 40$ & 16,53 & 16,55 & 0,017 & 1,227 & 1,218 & $-0,009$ & $-0,118$ & 3,27 \\
\hline $17: 00$ & 16,14 & 16,18 & 0,041 & 1,205 & 1,195 & $-0,010$ & $-0,257$ & 0,44 \\
\hline $17: 20$ & 15,98 & 16,04 & 0,059 & 1,202 & 1,193 & $-0,009$ & $-0,410$ & $-3,99$ \\
\hline $17: 40$ & 15,93 & 15,97 & 0,039 & 1,190 & 1,186 & $-0,004$ & $-0,610$ & $-5,68$ \\
\hline $18: 00$ & 15,92 & 15,96 & 0,034 & 1,181 & 1,184 & 0,003 & 0,709 & $-6,48$ \\
\hline
\end{tabular}


Anexo 22 - Evapotranspiração da cultura $\left(\mathrm{mm} .12 \mathrm{~h}^{-1}\right)$, medida pelo lisímetro de pesagem e estimada pelo sistema razão de Bowen (SRB), e velocidade média diurna do vento $\left(\mathrm{m} . \mathrm{s}^{-1}\right)$, ao longo do primeiro cultivo da alface, em Piracicaba, SP, no ano de 2000 .

\begin{tabular}{|c|c|c|c|c|c|}
\hline \multirow[t]{2}{*}{ DAT } & \multirow{2}{*}{$\begin{array}{c}\text { Dia } \\
\text { Juliano }\end{array}$} & \multicolumn{3}{|c|}{ Evapotranspiração da cultura $\left(\mathrm{mm} .12 \mathrm{~h}^{-1}\right)$} & \multirow{2}{*}{$\begin{array}{c}\text { Veloc. média } \\
\text { do vento }\left(\mathrm{m}^{-\mathrm{s}^{-1}}\right)\end{array}$} \\
\hline & & Lisimetro & SRB & SRB / lisímetro & \\
\hline 1 & 98 & 3,31 & 3,10 & 0,94 & 0,91 \\
\hline 2 & 99 & 3,33 & 2,80 & 0,84 & 0,70 \\
\hline 3 & 100 & 3,64 & 2,74 & 0,75 & 0,89 \\
\hline 4 & 101 & 3,47 & 2,57 & 0,74 & 1,16 \\
\hline 5 & 102 & 3,58 & 2,58 & 0,72 & 1,06 \\
\hline 6 & 103 & 3,74 & 2,57 & 0,69 & 1,36 \\
\hline 7 & 104 & 3,14 & 2,12 & 0,67 & 1,64 \\
\hline 8 & 105 & 3,52 & 2,51 & 0,71 & 0,98 \\
\hline 9 & 106 & 3,61 & 2,32 & 0,64 & 0,96 \\
\hline 10 & 107 & 3,45 & 2,21 & 0,64 & 1,54 \\
\hline 11 & 108 & 2,96 & 2,65 & 0,90 & 0,74 \\
\hline 12 & 109 & 1,09 & 1,12 & 1,02 & 0,80 \\
\hline 13 & 110 & 2,97 & 1,96 & 0,66 & 1,45 \\
\hline 14 & 111 & 3,65 & 2,59 & 0,71 & 2,23 \\
\hline 15 & 112 & 4,10 & 2,82 & 0,69 & 1,47 \\
\hline 16 & 113 & 3,24 & 2,82 & 0,87 & 2,02 \\
\hline 17 & 114 & 4,37 & 2,31 & 0,53 & 1,12 \\
\hline 18 & 115 & 3,40 & 2,74 & 0,81 & 1,04 \\
\hline 19 & 116 & 3,44 & 2,31 & 0,67 & 1,34 \\
\hline 20 & 117 & 3,41 & 2,35 & 0,69 & 1,46 \\
\hline 21 & 118 & 3,79 & 2,86 & 0,75 & 1,51 \\
\hline 22 & 119 & 3,91 & 2,71 & 0,69 & 1,68 \\
\hline 23 & 120 & 3,28 & 2,78 & 0,85 & $i, 31$ \\
\hline 24 & 121 & 3,47 & 2,89 & 0,83 & 1,08 \\
\hline 25 & 122 & 3,78 & 3,27 & 0,86 & 1,80 \\
\hline 26 & 123 & 2,92 & 2,43 & 0,83 & 1,95 \\
\hline 27 & 124 & 3,10 & 2,64 & 0,85 & 1,62 \\
\hline 28 & 125 & 3,38 & 2,74 & 0,81 & 1,50 \\
\hline 29 & 126 & 3,54 & 2,79 & 0,79 & 1,91 \\
\hline 30 & 127 & 1,54 & 1,21 & 0,78 & 1,83 \\
\hline \multirow[t]{3}{*}{31} & 128 & 2,86 & 2,70 & 0,94 & 0,89 \\
\hline & Média & 3,32 & 2,52 & 0,77 & 1,35 \\
\hline & Total & 102,99 & 78,18 & & \\
\hline
\end{tabular}


Anexo 23 - Evapotranspiração da cultura $\left(\mathrm{mm} .12 \mathrm{~h}^{-1}\right)$, medida pelo lisímetro de pesagem e estimada pelo sistema razão de Bowen (SRB), e velocidade média diurna do vento $\left(\mathrm{m} \mathrm{.}^{-1}\right)$, ao longo do segundo cultivo da alface, em Piracicaba, SP, no ano de 2000 .

\begin{tabular}{|c|c|c|c|c|c|}
\hline \multirow[t]{2}{*}{ DAT } & \multirow{2}{*}{$\begin{array}{c}\text { Dia } \\
\text { Juliano }\end{array}$} & \multicolumn{3}{|c|}{ Evapotranspiração da cultura $\left(\mathbf{m m} .12 \mathrm{~h}^{-1}\right)$} & \multirow{2}{*}{$\begin{array}{l}\text { Veloc. média } \\
\text { do vento }\left(\mathrm{m} . \mathrm{s}^{-1}\right)\end{array}$} \\
\hline & & Lisímetro & SRB & SRB / lisimetro & \\
\hline 1 & 176 & 1,84 & 0,55 & 0,30 & 3,45 \\
\hline 2 & 177 & 2,83 & 1,86 & 0,66 & 1,93 \\
\hline 3 & 178 & 2,55 & 0,95 & 0,37 & 1,93 \\
\hline 4 & 179 & 0,85 & 0,83 & 0,98 & 1,14 \\
\hline 5 & 180 & 2,69 & 1,74 & 0,65 & 2,36 \\
\hline 6 & 181 & 2,12 & 1,62 & 0,76 & 2,33 \\
\hline 7 & 182 & 0,99 & 0,48 & 0,48 & 1,38 \\
\hline 8 & 183 & 2,26 & 0,82 & 0,36 & 1,02 \\
\hline 9 & 184 & 2,69 & 1,80 & 0,67 & 2,09 \\
\hline 10 & 185 & 1,84 & 1,40 & 0,76 & 2,38 \\
\hline 11 & 186 & 2,12 & 1,86 & 0,87 & 2,21 \\
\hline 12 & 187 & 1,84 & 0,99 & 0,54 & 0,67 \\
\hline 13 & 188 & 2,41 & 1,63 & 0,68 & 1,85 \\
\hline 14 & 189 & 2,26 & 1,63 & 0,72 & 2,20 \\
\hline 15 & 190 & 2,26 & 1,48 & 0,65 & 2,17 \\
\hline 16 & 191 & 2,83 & 1,89 & 0,67 & 2,13 \\
\hline 17 & 192 & 2,83 & 2,56 & 0,90 & 2,64 \\
\hline 18 & 193 & 2,41 & 1,53 & 0,64 & 2,09 \\
\hline 19 & 194 & 0,99 & 0,89 & 0,90 & 1,67 \\
\hline 20 & 195 & 2,12 & 0,71 & 0,33 & 0,96 \\
\hline 21 & 196 & 2,26 & 1,48 & 0,65 & 1,22 \\
\hline 22 & 197 & 1,27 & 0,89 & 0,69 & 1,56 \\
\hline 23 & 198 & 2,26 & 2,36 & 1,04 & 3,32 \\
\hline 24 & 199 & 1,84 & 1,38 & 0,75 & 0,98 \\
\hline 25 & 200 & 1,84 & 0,84 & 0,45 & 1,25 \\
\hline 26 & 201 & 0,85 & 0,79 & 0,92 & 1,69 \\
\hline 27 & 202 & 1,70 & 1,43 & 0,84 & 0,72 \\
\hline 28 & 203 & 2,55 & 0,41 & 0,16 & 1,16 \\
\hline 29 & 204 & 2,26 & 1,50 & 0,66 & 2,47 \\
\hline 30 & 205 & 0,28 & 0,00 & 0,00 & 1,66 \\
\hline 31 & 206 & 2,55 & 1,41 & 0,55 & 1,01 \\
\hline 32 & 207 & 2,41 & 1,86 & 0,77 & 0,65 \\
\hline 33 & 208 & 2,26 & 1,50 & 0,66 & 0,90 \\
\hline 34 & 209 & 2,83 & 2,07 & 0,73 & 1,67 \\
\hline 35 & 210 & 2,83 & 1,91 & 0,68 & 0,79 \\
\hline
\end{tabular}

Continua $\ldots$ 
Anexo 23 - Evapotranspiração da cultura $\left(\mathrm{mm} .12 \mathrm{~h}^{-1}\right)$, medida pelo lisímetro de pesagem e estimada pelo sistema razão de Bowen (SRB), e velocidade média diurna do vento $\left(\mathrm{m} . \mathrm{s}^{-1}\right.$ ), ao longo do segundo cultivo da alface, em Piracicaba, SP, no ano de 2000 .

\begin{tabular}{|c|c|c|c|c|c|}
\hline \multirow[t]{2}{*}{ DAT } & \multirow{2}{*}{$\begin{array}{c}\text { Dia } \\
\text { Juliano }\end{array}$} & \multicolumn{3}{|c|}{ Evapotranspiração da cultura (mm.12 $\left.\mathrm{h}^{-1}\right)$} & \multirow{2}{*}{$\begin{array}{c}\text { Veloc. média } \\
\text { do vento }\left(\mathrm{m} \cdot \mathrm{s}^{-1}\right)\end{array}$} \\
\hline & & Lisimetro & SRB & SRB / lisimetro & \\
\hline 36 & 211 & 2,41 & 1,23 & 0,51 & 0,62 \\
\hline 37 & 212 & 3,40 & 2,30 & 0,68 & 1,92 \\
\hline 38 & 213 & 3,11 & 1,69 & 0,54 & $i, 48$ \\
\hline 39 & 214 & 2,12 & 1,35 & 0,64 & 0,73 \\
\hline 40 & 215 & 2,55 & 2,44 & 0,96 & 2,35 \\
\hline 41 & 216 & 1,51 & 1,40 & 0,93 & 1,64 \\
\hline 42 & 217 & 2,12 & 1,88 & 0,89 & 3,96 \\
\hline 43 & 218 & 2,97 & 2,33 & 0,78 & 1,88 \\
\hline & $\begin{array}{l}\text { Média } \\
\text { Total }\end{array}$ & $\begin{array}{c}2,16 \\
92,93\end{array}$ & $\begin{array}{c}1,43 \\
61,62\end{array}$ & 0,66 & 1,73 \\
\hline
\end{tabular}


Anexo 24 - Evapotranspiração $\left(\mathrm{mm} .12 \mathrm{~h}^{-1}\right)$, da cultura (ETc) e de referência, estimada com dados externos $\left(\mathrm{ETo}_{(\mathrm{De})}\right)$ e internos $\left(\mathrm{ETo}_{(\mathrm{Di})}\right)$, e coeficiente de cultivo, estimado com dados externos $\left(\mathrm{Kc}_{(\mathrm{De})}\right)$ e internos $\left(\mathrm{Kc}_{(\mathrm{Di})}\right)$, ao longo do primeiro cultivo da alface, em Piracicaba, SP, no ano de 2000.

\begin{tabular}{|c|c|c|c|c|c|c|c|c|}
\hline \multirow[t]{2}{*}{ DAT } & \multirow{2}{*}{$\begin{array}{c}\text { Dia } \\
\text { Juliano }\end{array}$} & \multirow{2}{*}{$\begin{array}{c}\text { ETc } \\
\text { Lisímetro }\end{array}$} & \multirow[t]{2}{*}{$\mathrm{ETO}_{(\mathrm{De})}$} & \multirow[t]{2}{*}{$\mathrm{ETO}_{(\mathrm{Di})}$} & \multirow{2}{*}{$\begin{array}{c}\text { ETCl } \\
\text { ETO(De) }\end{array}$} & \multirow{2}{*}{$\begin{array}{l}\text { ETc / } \\
\text { ETo(Di) }\end{array}$} & \multicolumn{2}{|c|}{ Coefic. de cultivo } \\
\hline & & & & & & & $K \mathbf{c}_{(\mathrm{De})}$ & $K c_{(D i)}$ \\
\hline 1 & 98 & 3,31 & 3,91 & 3,58 & 0,85 & 0,93 & & \\
\hline 2 & 99 & 3,33 & 3,86 & 3,25 & 0,86 & 1,02 & & \\
\hline 3 & 100 & 3,64 & 4,17 & 3,62 & 0,87 & 1,01 & & \\
\hline 4 & 101 & 3,47 & 4,31 & 3,63 & 0,80 & 0,96 & & \\
\hline 5 & 102 & 3,58 & 4,19 & 3,51 & 0,85 & 1,02 & 0,85 & 0,99 \\
\hline 6 & 103 & 3,74 & 4,99 & 3,69 & 0,75 & 1,01 & & \\
\hline 7 & 104 & 3,14 & 4,58 & 3,26 & 0,69 & 0,96 & & \\
\hline 8 & 105 & 3,52 & 4,63 & 3,48 & 0,76 & 1,01 & & \\
\hline 9 & 106 & 3,61 & 4,27 & 3,40 & 0,85 & 1,06 & & \\
\hline 10 & 107 & 3,45 & 4,42 & 3,22 & 0,78 & 1,07 & 0,76 & 1,02 \\
\hline 11 & 108 & 2,96 & 3,59 & 3,00 & 0,82 & 0,99 & & \\
\hline 12 & 109 & 1,09 & 2,09 & 1,66 & 0,52 & 0,66 & & \\
\hline 13 & 110 & 2,97 & 2,99 & 2,08 & 0,99 & 1,43 & & \\
\hline 14 & 111 & 3,65 & 4,56 & 3,14 & 0,80 & 1,16 & & \\
\hline 15 & 112 & 4,10 & 4,09 & 3,04 & 1,00 & 1,35 & 0,83 & 1,12 \\
\hline 16 & 113 & 3,24 & 3,68 & 2,47 & 0,88 & 1,31 & & \\
\hline 17 & 114 & 4,37 & 3,97 & 3,10 & 1,10 & 1,41 & & \\
\hline 18 & 115 & 3,40 & 3,85 & 2,98 & 0,88 & 1,14 & & \\
\hline 19 & 116 & 3,44 & 4,46 & 3,08 & 0,77 & 1,12 & & \\
\hline 20 & 117 & 3,41 & 4,03 & 2,85 & 0,85 & 1,20 & 0,90 & 1,24 \\
\hline 21 & 118 & 3,79 & 4,02 & 2,88 & 0,94 & 1,32 & & \\
\hline 22 & 119 & 3,91 & 4,20 & 2,97 & 0,93 & 1,32 & & \\
\hline 23 & 120 & 3,28 & 4,10 & 2,89 & 0,80 & 1,14 & & \\
\hline 24 & 121 & 3,47 & 3,79 & 2,59 & 0,92 & 1,34 & & \\
\hline 25 & 122 & 3,78 & 4,15 & 2,68 & 0,91 & 1,41 & 0,90 & 1,30 \\
\hline 26 & 123 & 2,92 & 3,72 & 2,26 & 0,78 & 1,29 & & \\
\hline 27 & 124 & 3,10 & 3,59 & 2,38 & 0,86 & 1,30 & & \\
\hline 28 & 125 & 3,38 & 3,62 & 2,36 & 0,93 & 1,43 & & \\
\hline 29 & 126 & 3,54 & 3,67 & 2,40 & 0,96 & 1,47 & & \\
\hline 30 & 127 & 1,54 & 1,82 & 1,06 & 0,85 & 1,46 & & \\
\hline 31 & 128 & 2,86 & 2,85 & 2,00 & 1,00 & 1,43 & 0,97 & 1,32 \\
\hline & $\begin{array}{l}\text { Média } \\
\text { Total }\end{array}$ & $\begin{array}{c}3,32 \\
102,99\end{array}$ & $\begin{array}{c}3,88 \\
120,16\end{array}$ & $\begin{array}{c}2,85 \\
88,48\end{array}$ & & & & \\
\hline
\end{tabular}


Anexo 25 - Evapotranspiração $\left(\mathrm{mm} \cdot 12 \mathrm{~h}^{-1}\right)$, da cultura (ETc) e de referência, estimada com dados externos $\left(\mathrm{ETo}_{(\mathrm{De})}\right)$ e internos $\left(\mathrm{ETo}_{(\mathrm{Di})}\right)$, e coeficiente de cultivo, estimado com dados externos $\left(\mathrm{Kc}_{(\mathrm{De})}\right)$ e internos $\left(\mathrm{Kc}_{(\mathrm{Di})}\right)$, ao longo do segundo cultivo da alface, em Piracicaba, SP, no ano de 2000.

\begin{tabular}{|c|c|c|c|c|c|c|c|c|}
\hline \multirow[t]{2}{*}{ DAT } & \multirow{2}{*}{$\begin{array}{c}\text { Dia } \\
\text { Juliano }\end{array}$} & \multirow{2}{*}{$\begin{array}{c}\text { ETc } \\
\text { Lisimetro }\end{array}$} & \multirow[t]{2}{*}{$\mathrm{ETO}_{(\mathrm{De})}$} & \multirow[t]{2}{*}{$E T O_{(\mathrm{Di})}$} & \multirow{2}{*}{$\begin{array}{c}\text { ETc I } \\
\text { ETO(De) }\end{array}$} & \multirow{2}{*}{$\begin{array}{l}\text { ETc } / \\
\text { ETo(Di) }\end{array}$} & \multicolumn{2}{|c|}{ Coefic. de cultivo } \\
\hline & & & & & & & $K \mathbf{c}_{(\mathrm{De})}$ & $K c_{(D i)}$ \\
\hline 1 & 176 & 1,84 & 4,19 & 2,50 & 0,44 & 0,74 & & \\
\hline 2 & 177 & 2,83 & 4,15 & 2,73 & 0,68 & 1,04 & & \\
\hline 3 & 178 & 2,55 & 3,37 & 2,26 & 0,76 & 1,13 & & \\
\hline 4 & 179 & 0,85 & 1,83 & 1,27 & 0,46 & 0,67 & & \\
\hline 5 & 180 & 2,69 & 4,01 & 2,52 & 0,67 & 1,07 & 0,60 & 0,93 \\
\hline 6 & 181 & 2,12 & 4,01 & 2,00 & 0,53 & 1,06 & & \\
\hline 7 & 182 & 0,99 & 1,37 & 0,98 & 0,72 & 1,01 & & \\
\hline 8 & 183 & 2,26 & 2,73 & 2,54 & 0,83 & 0,89 & & \\
\hline 9 & 184 & 2,69 & 3,77 & 2,72 & 0,71 & 0,99 & & \\
\hline 10 & 185 & 1,84 & 2,84 & 1,78 & 0,65 & 1,03 & 0,69 & 1,00 \\
\hline 11 & 186 & 2,12 & 2,63 & 1,92 & 0,81 & 1,11 & & \\
\hline 12 & 187 & 1,84 & 2,62 & 2,35 & 0,70 & 0,78 & & \\
\hline 13 & 188 & 2,41 & 3,22 & 2,39 & 0,75 & 1,01 & & \\
\hline 14 & 189 & 2,26 & 3,45 & 2,35 & 0,66 & 0,96 & & \\
\hline 15 & 190 & 2,26 & 3,15 & 1,99 & 0,72 & 1,14 & 0,73 & $\mathbf{1 , 0 0}$ \\
\hline 16 & 191 & 2,83 & 3,98 & 2,64 & 0,71 & 1,07 & & \\
\hline 17 & 192 & 2,83 & 4,30 & 2,63 & 0,66 & 1,08 & & \\
\hline 18 & 193 & 2,41 & 3,59 & 2,01 & 0,67 & 1,20 & & \\
\hline 19 & 194 & 0,99 & 1,52 & 0,75 & 0,65 & 1,33 & & \\
\hline 20 & 195 & 2,12 & 2,47 & 1,95 & 0,86 & 1,09 & 0,71 & 1,15 \\
\hline 21 & 196 & 2,26 & 2,81 & 2,22 & 0,80 & 1,02 & & \\
\hline 22 & 197 & 1,27 & 1,51 & 0,88 & 0,84 & 1,45 & & \\
\hline 23 & 198 & 2,26 & 3,18 & 2,07 & 0,71 & 1,09 & & \\
\hline 24 & 199 & 1,84 & 2,48 & 1,59 & 0,74 & 1,16 & & \\
\hline 25 & 200 & 1,84 & 2,13 & 1,65 & 0,87 & 1,12 & 0,79 & $\mathbf{1 , 1 7}$ \\
\hline 26 & 201 & 0,85 & 1,32 & 0,72 & 0,64 & 1,17 & & \\
\hline 27 & 202 & 1,70 & 1,94 & 1,45 & 0,88 & 1,17 & & \\
\hline 28 & 203 & 2,55 & 2,80 & 2,32 & 0,91 & 1,10 & & \\
\hline 29 & 204 & 2,26 & 2,91 & 1,66 & 0,78 & 1,37 & & \\
\hline 30 & 205 & 0,28 & 0,34 & 0,23 & 0,83 & 1,21 & 0,81 & 1,20 \\
\hline 31 & 206 & 2,55 & 2,19 & 1,64 & 1,16 & 1,56 & & \\
\hline 32 & 207 & 2,41 & 2,45 & 1,89 & 0,98 & 1,28 & & \\
\hline 33 & 208 & 2,26 & 2,63 & 1,78 & 0,86 & 1,27 & & \\
\hline 34 & 209 & 2,83 & 3,31 & 2,31 & 0,86 & 1,23 & & \\
\hline 35 & 210 & 2,83 & 3,07 & 2,20 & 0,92 & 1,29 & 0,96 & 1,32 \\
\hline
\end{tabular}


Anexo 25 - Evapotranspiração $\left(\mathrm{mm} .12 \mathrm{~h}^{-1}\right)$, da cultura (ETc) e de referência, estimada com dados externos $\left(\mathrm{ETo}_{(\mathrm{De})}\right)$ e internos $\left(\mathrm{ETo}_{(\mathbf{( i )})}\right)$, e coeficiente de cultivo, estimado com dados externos $\left(\mathrm{Kc}_{\left(\mathbf{D}_{e}\right)}\right)$ e internos $\left(\mathrm{Kc}_{(\mathrm{Di})}\right)$, ao longo do segundo cultivo da alface, em Piracicaba, SP, no ano de 2000.

\begin{tabular}{|c|c|c|c|c|c|c|c|c|}
\hline \multirow[t]{2}{*}{ DAT } & \multirow{2}{*}{$\begin{array}{c}\text { Dia } \\
\text { Juliano }\end{array}$} & \multirow{2}{*}{$\begin{array}{c}\text { ETc } \\
\text { Lisímetro }\end{array}$} & \multirow[t]{2}{*}{$\mathrm{ETO}_{(\mathrm{De})}$} & \multirow[t]{2}{*}{$E T O_{(D i)}$} & \multirow{2}{*}{$\begin{array}{c}\text { ETc I } \\
\text { ETo(De) }\end{array}$} & \multirow{2}{*}{$\begin{array}{c}\text { ETC I } \\
\text { ETO(Di) }\end{array}$} & \multicolumn{2}{|c|}{ Coefic. de cultivo } \\
\hline & & & & & & & $K \mathbf{c}_{(\mathrm{De})}$ & $K c_{\left(D_{i}\right)}$ \\
\hline 36 & 211 & 2,41 & 2,57 & 1,90 & 0,94 & 1,27 & & \\
\hline 37 & 212 & 3,40 & 3,62 & 2,38 & 0,94 & 1,43 & & \\
\hline 38 & 213 & 3,11 & 3,07 & 2,14 & 1,02 & 1,46 & & \\
\hline 39 & 214 & 2,12 & 2,54 & 1,51 & 0,83 & 1,41 & & \\
\hline 40 & 215 & 2,55 & 2,44 & 1,62 & 1,04 & 1,57 & 0,95 & 1,43 \\
\hline 41 & 216 & 1,51 & 1,97 & 0,94 & 0,77 & 1,60 & & \\
\hline 42 & 217 & 2,12 & 2,82 & 1,71 & 0,75 & 1,24 & & \\
\hline 43 & 218 & 2,97 & 2,93 & 1,89 & 1,02 & 1,57 & 0,84 & 1,47 \\
\hline & $\begin{array}{l}\text { Média } \\
\text { Total }\end{array}$ & $\begin{array}{c}2,16 \\
92,93\end{array}$ & $\begin{array}{c}2,80 \\
120,19\end{array}$ & $\begin{array}{c}1,88 \\
80,92\end{array}$ & & & & \\
\hline
\end{tabular}




\section{REFERÊNCIAS BIBLIOGRÁFICAS}

ABOUKHALED, A.; ALFARO, A.; SMITH, M. Lysimeters. Rome, FAO, 1982. 68p. (FAO Irrigation and Drainage Paper, 39).

ALLEN, R.G.; HILL, R.W.; SRIKANTH, V. Evapotranspiration parameters for variably-sized wetlands. Transactions of the ASAE, v.37, 1994. p.9. (Paper 2132).

AL-RIAHI, M.; AL-KARAGHOULI, A; HASSON, A.W. Relations between radiation fluxes of a greenhouse in semi-arid conditions. Agricultural and Forest Meteorology, v.44, p.329-338, 1989.

ANDRIOLO, J.L.; BURIOL, G.A.; ESTEFANEL, V. et al. Determinação das variações de temperatura do ar e do solo e da umidade relativa do ar no ambiente interno e externo de uma estufa de polietileno em Santa Maria, RS. In: ENCONTRO DE PlASTICUltURA DA REGIÃO SUL, 3, Curitiba, 1989. Resumos. Curitiba: p.6, 1989.

ANGUS, D.E.; WATTS, P.J. Evapotranspiration - How good is the Bowen ratio method? Agricultural Water Manegement, v.8, p.133-150, 1984.

ASHKTORAB, H.; PRUITT, W.O.; PAWU, K.T.; GEORGE, W.V. Energy balance determinations close to the soil surface using a micro-Bowen ratio system. Agricultural and Forest Meteorology, v.46, n.3, p.259-274. 1989. 
ASHKTORAB, H; PRUITT, W.O.; PAWU, K.T. Partitioning of evapotranspiration using lysimeter and micro-Bowen-ratio system. Journal of Irrigation and Drainage Engineering, v.120, n.2, p.450-464. 1994.

ASSIS, S.V.; ESCOBEDO, J.F. Radiação solar Global e Difusa em estufas com orientações leste-oeste e norte-sul. In: CONGRESSO BRASILEIRO DE AGROMETEOROLOGIA 10, Piracicaba, 1997. Anais. Piracicaba: Sociedade Brasileira de Agrometeorologia, 1997. p.536-540.

AZEVEDO, B.M. Evapotranspiração de referência obtida com a razão de Bowen, lisímetro de pesagem e equação de Penman-Monteith utilizando sistemas automáticos. Piracicaba, 1999. 81p. Tese (Doutorado) - Escola Superior de Agricultura "Luiz de Queiroz", Universidade de São Paulo.

BASELGA, J.J.; ALLEN, R.G. A Penman-Monteith for a semi-arid climate in southwestern spain. Transactions of the ASAE, v.39, p.999-1007, 1996.

BASTOS, E.A. Determinação dos coeficientes de cultura da alface (Lactuca sativa L.). Botucatu, 1994. 101p. Dissertação (Mestrado) - Faculdade de Ciências Agronômicas, Universidade Estadual Paulista.

BAUSCH, W.C.; BERNARD, T.M. Spatial averaging Bowen ratio system: description and lysimeter comparison. Transactions of the ASAE, v.35, p.121$128,1992$.

BERGAMASCHI, H.; OMETTO, J.C.; VIEIRA, H.J. Deficiência hídrica em feijoeiro, II Balanço de energia. Pesquisa Agropecuária Brasileira, v.1, n.1, p.745-757, 1988. 
BLAD, B.L.; ROSENBERG, N.J. Lysimetric calibration of the Bowen ratio-energy balance method for evapotranspiration estimation in the central great plains. Journal of Applied Meteorology, v. 13, p.227-236, 1974.

BLAND, W.L.; LOEW, J.T.; NORMAN, J.M. Evaporation from cranberry. Agricultural and Forest Meteorology. v.81, p.1-12, 1996.

BOULARD, T.; JEMAA, R. Greenhouse tomato crop transpiration model aplication to irigation control. Acta Horticulture, v.335, p.335-387, 1993.

BOWEN, I. S. The ratio of heat losses by conductions and by evaporation from any water surface. Physical Review Serial 2, 27, p.779-787, 1926.

BREMER, D.J.; HAM, J.M. Effect of spring burning on the surface energy balance in a tallgrass prairie. Agricultural and Forest Meteorology. v.97, n.1, p.43-54, 1999.

BRIGGS, G.E.; KIDD, F.; WEST, C. A quantitative analysis of plant growth. Annuary aplied Biology. v.7, p. 103-123, 1920.

BURIOL, G.A.; STRECK, N.A.; SCHNEIDER, F.M. Modificação ambiental causada por túneis baixos de polietileno transparente perfurado cultivados com alface. Ciência Rural, v.23, p.261-266, 1993 a.

BURIOL, G.A.; SCHNEIDER, F.M.; ESTEFANEL, V.; ANDRIOLO, J.L.; MEDEIROS, S.L.P. Modificação na temperatura mínima do ar causada por estufas de polietileno transparente de baixa densidade. Revista Brasileira de Agrometeorologia, v.1, n.1, p.43-49, 1993 b. 
BURIOL, G.A.; LUFT, S.V.L.; HELDEWEIN, A.B.; STRECK, N.A.; SCHNEIDER, F.M. Efeito da ventilação sobre a temperatura e umidade do ar em túneis baixos de polietileno transparente e o crescimento do alface. Revista Brasileira de Agrometeorologia, v.5, n. 1, p.17-24, 1995.

BURIOL, G.A.; HELDEWEIN, A.B.; STRECK, N.A.; SCHNEIDER, F.M.; ESTEFANEL, V.; Gradiente vertical de temperatura do ar no interior de estufas plásticas. In: CONGRESSO BRASILEIRO DE AGROMETEOROLOGIA 10, Piracicaba, 1997. Anais. Piracicaba: Sociedade Brasileira de Agrometeorologia, 1997. p.471-472.

CAMACHO, M.J.; ASSIS, F.N.; MARTINS, S.R.; MENDEZ, M.E.G. Avaliação de elementos meteorológicos em estufa plástica em Pelotas, RS. Revista Brasileira de Agrometeorologia, v.3, p.19-24, 1995.

CAMARGO, A.P. Balanço hídrico no Estado de São Paulo. Campinas, IAC, 1971. 28p. (Boletim técnico, 116).

CARGENEL, A.L.; BREVEDAN, R.E.; LUAYZA, G; PALOMO, R. Evapotranspiration measurements over a soybean crop. Transactions of the ASAE, v.39, p.304-308, 1996.

CELLIER, P; OLIOSO, A. A simple system for automated long-term Bowen ratio measurement. Agricultural and Forest Meteorology. v.66, p.81-92, 1993.

CHANG, J. Climate and agriculture. $2^{\mathrm{a}}$ ed. Chicago: Aldine Publishing Company, 1971. 296p. 
CLOTHIER, B.E.; KERR, J.P.; TALBOT, J.S. Measured and estimated evapotranspiration from weel-watered crops. New Zeland Journal of Agricultural Research. v.25, p.301-307, 1982.

CRUZ, R.F.R. Comparação do desempenho de dois tipos de lisímetros na determinação da evapotranspiração máxima da cultura da ervilha (Pisum sativum, L.). Piracicaba, 1995. 55p. Dissertação (Mestrado) - Escola Superior de Agricultura "Luiz de Queiroz", Universidade de São Paulo.

CUNHA, R.C.; BERGAMASCHI, H.; BERLATO, M.A.; MATZENAUER, R. Balanço de energia em cultura de milho. Revista Brasileira de Agrometeorologia, v.4, p.1-14, 1996.

DAAMEN, C.C.; DUGAS, W.A.; PRENDERGAST, P.T.; JUDD, M.J.; MCNAUGHTON, K.G. Energy flux measurements in a sheltered lemon orchard. Agricultural and Forest Meteorology. v.93, n.3, p.171-183, 1999.

DOORENBOS, J.; PRUITT, J.O. Guidlines for predicting crop water requirements. Rome: FAO, 1977. 179p. (FAO Irrigation and Drainage Paper, 24).

DUGAS,W.A.; FRITSCHEN, L.J.; GAY L.W.; HELD, A.A.; MATTHIAS A.D.; REICOSKY, D.C.; STEDUTO. P.; STEINER, J.L. Bowen ratio, eddy correlation, and portable chamber measurements of sensible and latent heat. Agricultural and Forest Meteorology. v.56, n.1-2, p.1-20, 1991.

DUNIN, F.X.; NULSEN, R. A., BAXTER, I.N.; GREENWOOD, E.A.N. Evaporation from a lupin crop: a comparison of methods. Agricultural and Forest Meteorology. v.46, n.4, p.297-311, 1989. 
FACCIOLI, G.G. Determinação da evapotranspiração de referência e da cultura da alface em condições de casa de vegetação, em Viçosa, MG. Viçosa, 1998. 85p. Dissertação (Mestrado) - Universidade Federal de Viçosa.

FARIAS, J.R.; BERGAMASCHI, H.; MARTINS, S.R.; BERLATTO, M.A.; OLIVERA, A.C.B. Alterações de temperatura e umidade relativa do ar provocadas pelo uso de estufa plástica. Revista Brasileira de Agrometeorologia, v.1, n.1, p.51-62, 1993a.

FARIAS, J.R.; BERGAMASCHI, H.; MARTINS, S.R.; BERLATTO, M.A. Efeito da cobertura plástica sobre a radiação solar. Revista Brasileira de Agrometeorologia, v.1, n.1, p.31-36, 1993b.

FARIAS, J.R.; BERGAMASCHI, H.; MARTINS, S.R. Evapotranspiração no interior de estufas plásticas. Revista Brasileira de Agrometeorologia, v.2, p.17-22, 1994.

FERNANDES, A.L.T. Monitoramento da cultura do crisântemo em estufa através do uso de lisímetro e estação agrometeorológica automatizados. Piracicaba, 1996. 96p. Dissertação (Mestrado) - Escola Superior de Agricultura "Luiz de Queiroz", Universidade de São Paulo.

FOLEGATTI, M.V.; SCATOLINI, M.E.; PAZ, V.P.S. et al. Efeitos da cobertura plástica sobre os elementos meteorológicos e evapotranspiração da cultura do crisântemo em estufa. Revista Brasileira de Agrometeorologia, v.5, n.2, p.155-163, 1997.

FONTANA, D.C.; BERLATO, M.A.; BERGAMASCHI, H. Balanço de energia em soja irrigada e não irrigada. Pesquisa Agropecuária Brasileira, v.3, n.26, p.403-410, 1991. 
FRANGI, J.P.; GARRIGUES, C; HABERSTOCK, F; FOREST, F. Evapotranspiration and stress indicator through Bowen ratio method. Transactions of the ASAE, v.39, p.800-805, 1996.

FUCHS, M.; TANNER, C.B. Error analysis of Bowen Ratyo measured by differential psycrometer. Agricultural Meteorology, v.7, p.329-334, 1970.

FURLAN, R.A.; SILVA, F.C.; FOLEGATTI, M.V. Avaliação do controle de temperatura no interior de ambientes protegidos através de nebulização. In: CONGRESSO BRASILEIRO DE AGROMETEOROLOGIA 11, Florianópolis, 1999. CDROM. Florianópolis: Sociedade Brasileira de Agrometeorologia, 1999.

GALVANI, E.; DANTAS, R.T.; ESCOBEDO, J.F.; KLOSOWSKI, E.S. Parâmetros meteorológicos em cultura de alface (Lactuca sativa, L.) cultivada em casa de vegetação com orientações leste-oeste, norte-sul e condições externa. Revista Brasileira de Agrometeorologia, v.6, n.2, p.157-163, 1998.

GRAFIADELLIS, M. A study of greenhouse covering plastic sheets. Acta Horticulture, v.170, p.133-142, 1985.

GRANT, D.R. Comparision of evaporation measurements using different methods. Quarterly Journal Research Meteorological Society, v.101, p.543-550, 1975.

GREEN, A.E.; CLOTHIER, B.E.; KERR, J.P.; SCOTTER, D.R. Evapotranspiration from pasture: a comparison of lysimeter and Bowen ratio measurements with Priestley-Taylor estimates. New Zealand Journal of Agricultural Research. v.27, n.3, p.321-327, 1984. 
GUTIERREZ, M.V.; MEINZER, F.C. Energy balance and latent heat flux partiotining in coffee hedgerows at different stages of canopy development. Agricultural and Forest Meteorology, v.68, p.173-186, 1994.

GUYOT, G. Les effets aérodynamiques et microclimatiques des brise-vent et des aménogements régionaux. In: REIFSNYDER, W.S.; DARNHOFER, I.O. Meteorology and Agroforesthy. Nairoby: ICRAF, 1989. p.485-520.

HAMADA, E. Desenvolvimento e produtividade da alface (Lactuca sativa L.), submetida à diferentes lâminas de água, através da irrigação por gotejamento. Campinas, 1993. 102p. Dissertação (Mestrado) - Faculdade de Engenharia Agrícola. Universidade Estadual Paulista.

HATFIELD J.L.; PRUEGER J.H.; SAUER T.J. Comparison of evapotranspiration equations over different surfaces. Transactions of the ASAE, v.39, p.10651070, 1996.

HEILMAN, J.L.; BRITTIN, C.L. Fetch requirement for Bowen ratio measurement of latent and sensible heat fluxes. Agricultural and Forest Meteorology, v.44, p.261-273, 1989.

HERBST, M; KAPPEN, L; THAMM, F; VANSELOW, R. Simultaneous measurements of transpiration, soil evaporation and total evaporation in a maize field in northern Germany. Journal of Experimental Botany, v.47, p.19571962, 1996.

HERTER, F.G.; REISSER JR, C. Balanço térmico em estufas plásticas em Pelotas, RS. Horticultura Brasileira, v.5, n. 1, p.60, 1987. 
HOWELL, T.A.; SCHNEIDER, A.D.; JENSEN, M.E. History of lysimeter desing and use for evapotranspiration. Lysimeter for evapotranspiration and enviroment measurements. New York: ASCE, 1991. p.1-19.

IBANEZ, M.; PEREZ, P.J.; ROSELL, J.I.; CASTELLVI, F. Estimation of the latent heat flux over full canopy covers from the radiative temperature Journal of Applied Meteorolgy, v.38, n.4, p.423-431, 1999.

JARA, J.; STOCKLE, C.O.; KJELGAARD, J.; Measurement of evapotranspiration and its components in a corn (Zea Mays L.) field. Agricultural and Forest Meteorology, v.92, p.131-145, 1998.

JENSEN, M.E. Consumptive of water and irrigation water requeriments. New York: ASCE, 1973. 215p.

JOINER, D.W.; MCCAUGHEY, J.H.; LAFLEUR, P.M.; BARTLETT, P.A. Water and carbon dioxide exchange at a boreal young jack pine forest in the boreas northern study area. Journal of Geophysical Research Atmospheres, v.104, n.22, p.27641-27652, 1999.

KJELGAARD, J.F.; STOCKLE, C.O.; VILLAR MIR, J.M.; EVANS, R.G.; CAMPBELL, G.S. Evaluating methods to estimate corn evapotranspiration from short-time interval weather data. Transactions of the ASAE, v.37, p.1825-1833, 1994.

KJELGAARD, J.F.; STOCKLE, C.O.; EVANS, R.G. Accuracy of canopy temperature energy balance for determining daily evapotranspiration. Irrigation Science, v.16, n. 4, p.149-157, 1996. 
KROON, L.J.M. Profile derived estimation of evaporation after a change in vegetative cover: a numerical approach. IAHS-Publication, v.177, p.175-183, 1989.

KURATA, K. Role of reflection in light transmissivity of greenhouses. Agricultural and Forest Meteorology, v.52, p.319-331, 1990.

KUSTAS, W.P.; STANNARD, D.I.; ALLWINE, K.J. Variability in surface energy flux partiotining during Washita 92 : resulting efects on Penaman-Monteith and Priestly-Taylor parameters. Agricultural and Forest Meteorology, v.82, p.171-193, 1996.

LEMON, E.R. Photosyntesis under Field Conditions: II. An aerodynamic Method for determing the turbulent Carbon Dioxide Exchange between the Atmosfere and a corn field. Agronomy Journal, v.52, p.697-703, 1960.

LEVIT, G.J.; GASPAR, R. Energy budget for greenhouses in humid-temperature climate. Agricultural and Foerest Meteorology, v.44, p.241-254, 1988.

LIRA, R.; OLIVEIRA, F.B. Balanço de energia sobre um canavial na zona da mata alagoana - comparação inverno/verão. In: CONGRESSO BRASILEIRO DE AGROMETEOROLOGIA 10, Piracicaba. Anais. Piracicaba: Sociedade Brasileira de Agrometeorologia, 1997. p.538-540.

LOWE, P.R. An aproximating polynomial for computation of saturation vapor pressure. Journal of Applied Meteorology, v.16, p.100-103, 1976. 
MAHRER, Y. Physical principles of solar heating of soils by plastic mulching in the filed and glasshouse and simulation models. In: Soil solarization, Boca Raton, Florida, 1991.

MAKI, T. Methods for estimating evapotranspiration under wet and arid field conditions. Japan Agricultural Research Quarterly, v.25, n.3, p.214-221, 1991.

MAI-EK, E. Rapid changes of the surface soil heat flux and its effects on the estimation of evapotranspiration. Journal of Hydrology, v.142, p.89-97. 1993.

MAI-EK, E.; BINGHAM, G.E. Comparison of the Bowen ratio-energy balance and the water balance methods for the measurement of evapotranspiration. Journal of Hydrology, v.146, p.209-220. 1993.

MAI-EK, E.; BINGHAM, G.E.; MCCURDY, G. Annual mesoscale study of water balance in a Great Basin heterogeneous desert valley. Journal of Hydrology, v.191, p.223-244. 1997.

MAI-EK, E., BINGHAM, G.E. Partitioning of radiation and energy balance components in an inhomogeneous desert valley. Journal of arid enviroments, v.37, n.2, p.193-207. 1997.

MANTOVANI, E.C. Desarollo y evaluación de modelos para el manejo del riego: estimación de la evapotranspiración y efectos de la uniformidad de aplicación del riego sobre la producción de los cultivos. Córdoba, 1993. 184p. Tese (Doutorado). ETSA.

MARTIN, E.C.; ROBLEDO, L.V. Aplication de los plásticos em la agricultura. Madrid: Mundi-Prensa, 1981, 55p. 
MARTINEZ GARCIA, P.F. Características climáticas de los invernaderos de plástico. Madrid: Instituto Nacional de Investigaciones Agrárias - INIA. (Hojas Tecnica, 19) 1978. 48p.

MARTINEZ GARCIA, P.F. La regulación de las condiciones del ambiente el los cultivos protegidos. In: FEIRA TECNICA INTERNACIONAL DE LA MAQUINARIA AGRICOLA. Zaragoza, 1986. Anais. Zaragoza: Associación Nacional de Ingenieros Agronomos, 1986. p.135-147.

MARTINS, G. Uso da casa de vegetação com cobertura plástica na tomaticultura de verão. Jaboticabal, 1992. 65p. Tese (Doutorado) - Faculdade de Ciências Agrárias e Veterinária, Universidade Estadual de São Paulo.

MARTINS R.S.; GONZALES, J.F. Avaliação da temperatura interna de estufa plástica dotada com sistema de calefação por fluxo de ar quente. Revista Brasileira de Agrometeorologia, v.3, p.5-11, 1995a.

MARTINS R.S; GONZALES, J.F. Evapotranspiração e respostas fisiológicas do feijão-vagem cultivado em substrato em estufa com sistema de ventilação/calefação. Revista Brasileira de Agrometeorologia, v.3, p.31-37, 1995b.

MASTRORILLI, M.; LOSAVIO, N; SCARASCIA, M.E.V.; KATERJI, N. Comparison of methods of measuring maximum evapotranspiration of a meadow in a Mediterranean climate. Rivista di Agronomia, v.23, n.2, p.202-209. 1989.

McMILLAN, W.D.; PAUL, H.A. Floating lysimeter. Agricultural Eng., v.42, p.498-499. 1961. 
MILLAR, A.A. Manejo racional da irrigação: uso de informações básicas sobre diferentes culturas. Brasília: IICA, 1984. 65p.

MILLAR, B.D. Effect of local advection on evaporation and plant water status. Australian Journal of Agriculture, v.25, p.97-106, 1964.

MILLS, P. J.W.; SMITH, I.E.; MORAIS, G. A greenhouse design for a cool subtropical climate with mild winters based in microclimatic measurements of protected environmentes. Acta Horticulture, v.281, p.83-93, 1990.

MONTERO, J.I.; CASTILLA, N.; GUTIERREZ DE RAUÉ, E.; BRESTONES, F. Climate under plastic in the Almeria area. Acta Horticulture, v.170, p.227$234,1985$.

MONTEITH, J.L. Evaporation and enviroment. Symp. Society Exploration Biology, v.19, p.205-234, 1965.

MONTEITH, J.L. Principles of environmental physics. London: Edward Arnold, 241p. 1973.

MOURA, A.L.; MARTINS, D. Comparação da estimativa horária da evapotranspiração através de diferentes métodos. Energia na Agricultura, v.7, n.3, p.4-11, 1992.

NIE, D.; FLITCROFT, I.D.; KANEMASU, E.T. Performance of Bowen ratio systems on a slope. Agricultural and Forest Meteorology, v.59, n.3-4, p.165$181,1992$. 
OLIVEIRA, G.M.; LEITÃO V.B.R.; CANDIDO; L.A.; AZEVEDO.P.V.; AMORIM NETO, M.S.; BEZERRA, J.R.C. Uma análise dos componentes do balanço de energia sobre um cultivo de amendoim irrigado. In: CONGRESSO BRASILEIRO DE AGROMETEOROLOGIA 10, Piracicaba, 1997. Anais. Piracicaba: Sociedade Brasileira de Agrometeorologia, 1997. p.535-537.

OMETTO, J.C. Bioclimatologia vegetal. São Paulo: Editora Agronômica Ceres, $1981,440 \mathrm{p}$.

ORTEGA-FARIAS, S.O.; CUENCA, R.H.; EK, M. Daytime variation of sensible heat flux estimated by the bulk aerodynamic method over a grass canopy. Agricultural and Forest Meteorology, v.81, p.131-143. 1996.

PELTON, W.L.; KING, K.M.; TANNER, C.B. Na evaluating of the Thornthwaite and mean temperature methods for determining potential evapotranspiration. Agronomy Journal, v.52, n.7, p.387-395, 1960.

PEREIRA, A.R. Introdução à Micrometeorologia. Piracicaba: ESALQ, Departamento de Física e Meteorologia, 1998. 70p.

PEREIRA, A.R.; MACHADO, E.C. Análise quantitativa do crescimento de comunidades vegetais. Boletim Técnico - Instituto Agronômico. n.114, p.133, 1987.

PEREIRA, A.R.; VILLA NOVA, N.A.; SEDIYAMA, G.C. Evapo(transpi)ração. Piracicaba: FEALQ, 1997. $183 \mathrm{p}$.

PEREIRA, N.N.C.; LEAL, N.R. Recomendações para a cultura do alface. Informe Técnico Pesagro, Rio. Rio de Janeiro: n.21, p. 1-12, 1989. 
PEREZ, P.J.; CASTELlVI, F.; IBAÑEZ, M.; ROSELL, J.I. Assessment of reliability of Bowen raui method for partitioning fluxes. Agricultural and Forest Meteorology, v.97, p.141-150, 1999.

PETERSCMITT, J.M.; KATERJI, N. Comparison of different methods for measuring evapotranspiration in non-irrigated wheat. Agronomie, v.9, n.2, p.197-205, 1989.

PEZZOPANE, J.E.M. Uso de estufa com cobertura plástica e de quebra-ventos na produção de porta enxertos de seringueira, na região de Campinas-SP. Piracicaba, 1994. 87p. Dissertação (Mestrado) - Escola Superior de Agricultura "Luiz de Queiroz", Universidade de São Paulo.

PRADOS, N.C. Contribution al estudio de los cultivos enarenados em Almeria: necessidades hídricas y extraction del nutrientes del cultivo de tomate de crescimento indeterminado en abrigo de polietileno. Almeria, 1986. 185p. Tesis (Doutorado) - Caja Rural Provincial, 1986.

PRUEGER J.H.; HATFIELD J.L.; AASE J.K.; PIKUL JR J.L. Bowen-ratio comparisons with lysimeter evapotranspiration. Agronomy Journal, v.89, n.5, p.730-736, 1997.

PRUITT, W.O; ANGUS, D.E. Large weighing lysimeter for measuring evapotranspiration. Transactions of the ASAE, v.3, n.2., p.13-15, 1960.

PRUITT, W.O.; LAURENCE, F.J.; VON OETTINGEM, S. Water use by crops as affected by climate and plant factors. California Agriculture, v.26, p.10-14, 1972. 
REIS, N.V.B.; CARRIJO, A.O. Estufa, material de cobertura e cortinamento durabilidade e transparência à radiação solar. In: CONGRESSO BRASILEIRO DE AGROMETEOROLOGIA 11, Florianópolis, 1999. CDROM. Florianópolis: Sociedade Brasileira de Agrometeorologia, 1999.

RESCHKE, G.A.; COSTA, J.M.N.; PRATES, J.E.; SEDIYAMA, G.C.; ROCHA., H.R. Razão de Bowen em áreas de pastagem e de floresta em Ji-Paraná, RO. In: CONGRESSO BRASILEIRO DE AGROMETEOROLOGIA 10, Piracicaba, 1997. Anais. Piracicaba: Sociedade Brasileira de Agrometeorologia, 1999. p.547-548.

RESI, N.V.B. Diferencial entre os parâmetros de temperaturas interna e externa de uma estufa modelo teto em arco - efeito guarda chuva. In: CONGRESSO BRASILEIRO DE AGROMETEOROLOGIA 10, Piracicaba, 1997. Anais. Piracicaba: Sociedade Brasileira de Agrometeorologia, 1997. p.465-467.

RITCHIE, J.T.; BURNET, E. A precision weighing lysimeter for row crop use studies. Agronomy Journal, v.60, p.545-549, 1968.

ROBLEDO DE PEDRO, F.; VICENTE, L.M. Aplicacion de los plásticos en la agricultura. $2^{2}$ ed. Madrid: Mundi-Prensa, 573p., 1988.

ROSENBERG, N.J. Microlimate: The biological enviroment. New York: John Wiley \& Sons., 1983. 315p.

ROSENBERG, N.J.; McKENNEY, M.S.; MARTIN, P. Evapotranspiration in a greenhouse-warmed world: A review and a simulation. Agricultural and Forest Meteorology, v.47, p.303-320, 1989. 
ROSSET, M.; RIEDO, M.; GRUB, A.; GEISSMANN, M.; FUHRER, J. Seasonal variation in radiation and energy balances of permanent pastures at different altitudes. Agricultural and Forest Meteorology, v. 86, p.245-258, 1997.

RYDER, E.J. Lettuce, Leafy salad vegetables. Westport:AVI, p.13-94., 1979.

SAUER, T.J.; HATFIELD, J.L.; PRUEGER, J.H.; NORMAN, J.M. Surface energy balance of a corn residue-covered field. Agricultural and Forest Meteorology, v. 89, p.155-168, 1998.

SCATOLINI, M.E. Estimativa da evapotranspiração da cultura de crisântemo em estufa a partir de elementos meteorológicos. Piracicaba, 1996. 71p. Dissertação (Mestrado) - Escola Superior de Agricultura "Luiz de Queiroz", Universidade de São Paulo.

SCHIEDECK, G.; MIELE, A.; BARRADAS, C.I.N.; MANDELLI, F. Efeito da temperatura e da umidade relativa do ar na fenologia da videira niágara rosada cultivada sob estufa de plástico. In: CONGRESSO BRASILERO DE AGROMETEOROLOGIA 10, Piracicaba, 1997. Anais. Piracicaba: Sociedade Brasileira de Agrometeorologia, 1997. p.35-37.

SCHNEIDER, F.M.; BURIOL, G.A.; ANDRIOLO, J.L.; ESTEFANEL, V.; STRECK, N.A. Modificação da temperatura do solo causada por estufas de polietileno transparente de baixa densidade em Santa Maria, RS. Revista Brasileira de Agrometeorologia, v.1, n.1, p.37-42, 1993.

SEEMAN, J. Greenhouse climate. In: SEEMAN, J. et al. Agrometeorology. New York: Springer-Verlag, 1979. p.165-178. 
SENTELHAS, P.C.; VILLA NOVA, N.A.; ANGELOCCI, R.L. Efeito de diferentes tipos de cobertura, em mini estufas, na atenuação da radiação solar e da luminosidade. In: CONGRESSO BRASILEIRO DE AGROMETEOROLOGIA 10, Piracicaba, 1997. Anais. Piracicaba: Sociedade Brasileira de Agrometeorologia, 1997. p.482-484.

SENTELHAS, P.C; MARIN, F.R; PEREIRA, A.R.; ANGELOCCI, L.R.; VILLA NOVA, N.A.; BARBIERI, V. Análise dos dados climáticos e de balanço hídrico climatológico de Piracicaba (1917-1997). Piracicaba: DFM/ESALQ/USP. 1998. 81p.

SENTELHAS, P.C.; BORSATTO, R.S.; MINAMI, K. Transmissividade da radiação solar em estufas cobertas com filmes de PVC azul e transparente. Revista Brasileira de Agrometeorologia, v.7, n.2, p.157-162, 1999.

SILVA, F.C. Determinação da evapotranspiração utilizando o método do balanço de energia e lisímetro de pesagem. Piracicaba, 2000. 72p. Tese (Doutorado) Escola Superior de Agricultura "Luiz de Queiroz", Universidade de São Paulo.

SILVA, F.C.; FOLEGATTI, M.V.; MAGGIOTTO, S.R. Análise do funcionamento de um lisímetro de pesagem com célula de carga. Revista Brasileira de Agrometeorologia, v.7, n.1, p.53-58, 1999.

SILVA, F.C.; FOLEGATTI, M.V.; PEREIRA, A.R.; VILA NOVA, N.A. Uso de dispositivos lisimétricos para medida da evapotranspiração de referência. Revista Brasileira de Agrometeorologia, v.7, n.1, p.19-23, 1999.

SLATIER, R.O.; McILROY, I.C. Pratical microclimatology. Canberra: CSIRO, 328p. 1961. 
STANHLL, G. The use of the Piche evaporimeter in the calculation of evaporation. Quartely Journal Research Meteorological Society, v.88, p.80-82, 1962.

STEDUTO, P.; HSIAO, T.C. Maize canopies under two soil water regimes. IV. Validity of Bowen ratio-energy balance technique for measuring water vapor and carbon dioxide fluxes at 5-min intervals. Agricultural and Forest Meteorology, v.89, p.215-228, 1998.

SUZUKI K.; OHTA T.; MIYA H.; YOKOTA S. Seasonal variation of heat balance components over a Japanese red pine forest in snowy northern Japan. Hidrological Process, v.13, n.14-15, p.2409-2421, 1999.

TANAKA, M.; GENTA, H. Control del medio ambiente bajo invernadero y tunel plastico. Salto: Estación Experimental de Citricultura, 1982. 61p.

TANNER, B.D.; GREENE, J.P.; BINGHAM, G.E. A Bowen-ratio design for long term measurements. Transactions of the ASAE, p. 1-6, 1987.

TANNER, C.B. Energy balance approach to evapotranspiration from crops. Soil Science Society of America. Proceedings. v. 24, n. 1, p.1-9. 1960.

TAPIA, G.J. Filmes térmicos para invernaderos. Revista de los Plásticos Modernos, v.295, p.75-82, 1981.

THORNTWAITE, G.W. An approach toward a rational classification of climate. Geographycal Reviews, New York, v.38, n.1, p.55-94. 1948.

TOURULA, T.; HEIKINHEIMO, M. Modelling evapotranspiration from a barley field over the growing season. Agricultural and Forest Meteorology, v.91, p.237-250, 1998 
UHLAND, H.E., HOUSER, P.R.; SHUTTLEWORTH, W.J.; YANG, Z.L. Surface flux measurement and modelling at a semi-arid Sonoran Desert site. Agricultural and Forest Meteorology, v.82, p.119-153. 1996.

VESCHAMBRE, D; VAYSSE, P. Measurements of evaporation in greenhouses for determing the requirements of plants. Horticulture, v.14, p.207-221, 1980.

VILLA NOVA, N.A. Estudos sobre o balanço de energia em cultura de arroz. Piracicaba, 1973. 78 p. Tese (Livre docência) - Escola Superior de Agricultura "Luiz de Queiroz", Universidade de São Paulo.

VILLA NOVA, N. A.; REICHARDT, K. Evaporação e evapotranspiração. In: RAMOS, F.; OCCHIPINTI, A.G.; VILLA NOVA, N.A.; REICHARDT, K.; MAGALHÃES, P.C.; CLEARY, R.W. Engenharia hidrológica. Rio de Janeiro: ABRH, 1989. Cap. 3, p.145-97. (Coleção ABRH de Recursos Hídricos, 2).

VILLELE, O. Probleme de bioclimatologie estimation des besoins en eau des culturies de serre. France: Comission economique pour l'Europe/Comité des problems agrícoles, 1989. 16p. (Seminaire, Nations Unies).

WILLMOTT, C.J. On the validation of models. Physical Geography, v.2, p.184$194,1981$. 